\title{
OSVALDO LACERDA: OBRA PARA VIOLÃO
}

Dissertação apresentada à Escola de Comunicações e Artes da

Universidade de São Paulo para obtenção do título de Mestre em Música

Área de Concentração: Processos de Criação Musical

Linha de pesquisa: Performance

Orientador: Prof. Dr. Edelton Gloeden

São Paulo 
Autorizo a reprodução e divulgação total ou parcial deste trabalho, por qualquer meio convencional ou eletrônico, para fins de estudo e pesquisa, desde que citada a fonte.

Catalogação na Publicação

Serviço de Biblioteca e Documentação

Escola de Comunicações e Artes da Universidade de São Paulo

Dados inseridos pelo(a) autor(a)

Vieira, Lucas de Oliveira

Osvaldo Lacerda: Obra para violão / Lucas de Oliveira

Vieira ; orientador, Edelton Gloeden. -- São Paulo, 2020.

$168 \mathrm{p}$.

Dissertação (Mestrado) - Programa de Pós-Graduação em Música

- Escola de Comunicações e Artes / Universidade de São Paulo.

Bibliografia

Versão original

1. Osvaldo Lacerda 2. Violão 3. Revisões 4. Versões 5.

Edições I. Gloeden, Edelton II. Título.

CDD 21.ed. - 780 
NOME: VIEIRA, Lucas de Oliveira

\section{Título: Osvaldo Lacerda: Obra para violão}

Dissertação apresentada à Escola de Comunicações e Artes da Universidade de São Paulo para obtenção do título de Mestre em Música

Aprovado em:

\section{Banca Examinadora}

Prof. Dr.

Instituição:

Julgamento:

Prof. Dr.

Instituição:

Julgamento:

Prof. Dr.

Instituição:

Julgamento: 


\section{AGRADECIMENTOS}

À CAPES, pelo apoio financeiro.

Aos meus pais e irmão, pelo incessante apoio.

A todos os amigos e colegas que tornaram esta caminhada possível.

O presente trabalho foi realizado com apoio da Coordenação de Aperfeiçoamento de Pessoal de Nível Superior Brasil (CAPES) - Código de Financiamento 001. 


\section{RESUMO}

O trabalho irá reunir e trazer à tona a pouco conhecida obra para violão solo e a música de câmara para este instrumento escrita pelo compositor paulista Osvaldo Lacerda (1927 2011). Esta é constituída por três peças para violão solo, três canções para voz e violão e três manuscritos de versões inacabadas do autor para flauta e violão, originalmente escritas para flauta e piano. Partindo das fontes primárias na forma de partituras manuscritas, serão apresentadas edições completas, com revisões, digitações e sugestões técnico-interpretativas, além do resgate das obras incompletas em versões possíveis para flauta e dois violões. No decorrer da dissertação, será traçado um panorama histórico ao redor de Lacerda, suas possíveis influências, paralelos com obras do próprio compositor e de outros autores contemporâneos à época.

Palavras chave: Osvaldo Lacerda, violão, revisões, versões, edições. 


\begin{abstract}
The work will bring together and bring to light the little-known work for solo guitar and chamber music for this instrument written by the composer Osvaldo Lacerda (1927 - 2011). They consists of three pieces for solo guitar, three songs for voice and guitar and three manuscripts of unfinished versions of the author for flute and guitar, originally written for flute and piano. Starting from the primary sources in the form of handwritten scores, a complete edition will be presented, with revisions, typing and technical-interpretive suggestions, in addition to the rescue of incomplete works in possible versions for flute and two guitars. During the dissertation, a historical panorama around Lacerda, its possible influences, will be traced, parallel to works by the composer himself and other contemporary authors at the time.
\end{abstract}

Keywords: Osvaldo Lacerda, classical guitar, revisions, versions, editions. 


\section{SUMÁRIO}

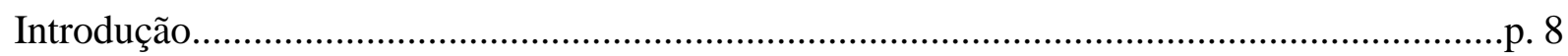

Capítulo 1: A escola nacionalista de Camargo Guarnieri.................................................... 9

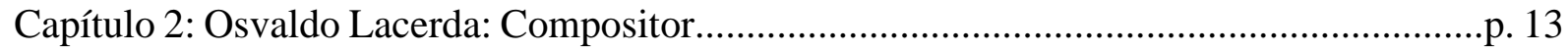

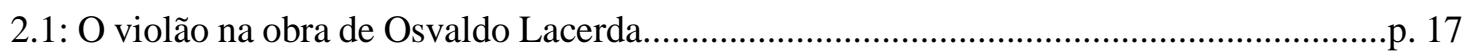

2.2: Breve entrevista com Maria Livia São Marcos................................................................. 20

Capítulo 3: Apontamentos técnico-interpretativos...........................................................p. 21

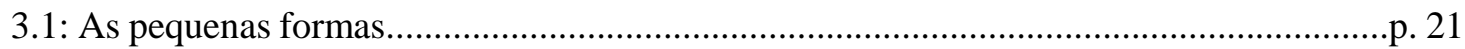

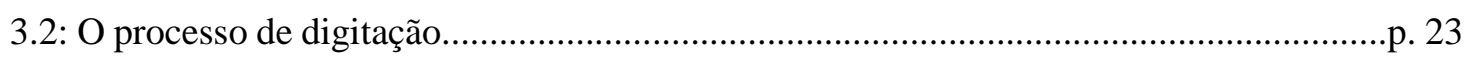

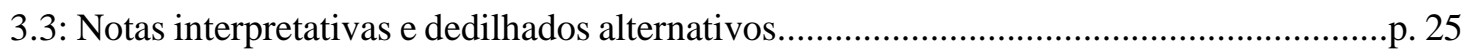

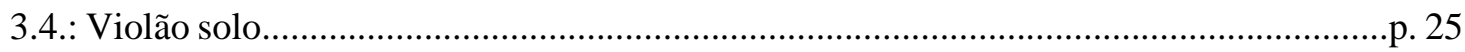

3.5: Canções para voz e violão.......................................................................................... 37

3.6: Versões para flauta e dois violões (original para flauta e piano)........................................ 41

Capítulo 4: Partituras revisadas, editadas e digitadas......................................................... 50

4.1: Violão solo

4.1.1: Ponteio

4.1.2: Valsa

4.1.3: Moda Paulista

4.2: Voz e violão

4.2.1: As dádivas

4.2.2: Vácuo

4.2.3: Saudade

4.3: Flauta e dois violões

4.3.1: Cantilena

4.3.2: Poemeto

4.3.3: Toccatina

Considerações finais.

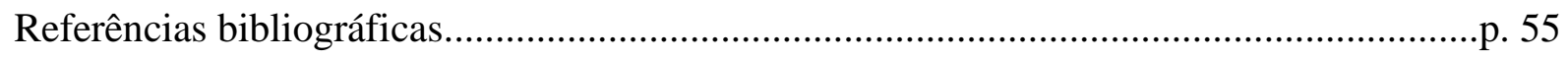

Apêndices............................................................................................................ 58

Entrevista de Osvaldo Lacerda a Fernando Cupertino (UFG, 2008).........................p. 58

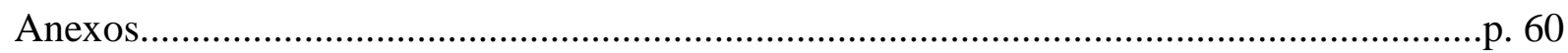

Vídeo: Prêmio Pós-Graduação USP 2019.............................................................p. 60

Partituras manuscritas

Versões inacabadas e partituras originais para flauta e piano 


\section{INTRODUÇÃO}

A sucinta obra para violão de Osvaldo Lacerda, assinala um importante período para o repertório nacional de concerto do instrumento, com a produção de compositores como Dinorah de Carvalho (1895 - 1980), Francisco Mignone (1897 - 1986), Radamés Gnattali (1906 1988), Camargo Guarnieri (1907 - 1993), Theodoro Nogueira (1913 - 2002), César GuerraPeixe (1914 - 1993), Lina Pires de Campos (1918 - 2003) Sérgio Vasconcellos Corrêa (1934) e Aylton Escobar (1943). As obras de Lacerda que abordam o violão, apesar de serem de qualidade superlativa, são ainda não muito conhecidas. Necessitam de um olhar técnico, revisional e editorial mais cuidadoso, pois permanecem pouco familiares não apenas devido ao alto grau de complexidade técnica, mas também à dificuldade de acesso à este material.

No decorrer deste texto, serão utilizadas ferramentas técnico-interpretativas para a construção de uma performance ao instrumento, frente aos problemas de execução por ser um compositor não violonista.

O trabalho revisional com as intervenções técnicas, auxiliará numa busca por suas relações com outras obras de Lacerda, permitindo visualizar os materiais utilizados além de propor reflexões e soluções de um ponto de vista prático. Para que desta forma os recursos instrumentais sejam utilizados de maneira eficaz, resultando em práticas que viabilizem uma execução coerente, procurando um alinhamento possível ao pensamento composicional do autor.

Mesmo com um olhar atual mais focado e interessado nas obras de Lacerda, com suas peças para coro, música de câmara e piano sendo difundidas com festivais e concursos, sua produção para violão permanece um pouco distante e carente dessa disseminação. Justamente devido ao pouco conhecimento destas obras, as mesmas nem mesmo chegam às mãos dos intérpretes e estudantes. Permanecendo assim, pouco tocadas e estudadas, tendo suas dificuldades de execução e trechos desconfortáveis pouco ou quase não resolvidos.

Este trabalho se propõe a construir uma edição com revisão detalhada, baseada em seu contexto histórico para a performance desta obra instigante. 


\section{CAPÍTULO 1}

\section{A ESCOLA NACIONALISTA DE CAMARGO GUARNIERI}

A música brasileira tem uma história longa, rica e intricada. Desde o período colonial, se nutre das três principais origens: os povos indígenas, os escravos negros e os colonizadores europeus.

As fortes correntes de cunho nacionalista que se sucederam por todo o mundo no decorrer do século XX, principalmente, encontraram no Brasil, o movimento Modernista e a figura de Mario de Andrade como seu maior apoiador. No âmbito musical, precedido por Heitor Villa-Lobos, Camargo Guarnieri foi um dos compositores que mais iria se apropriar, desenvolver e defender essas ideias.

Compositor de inquestionável valor e excelência, nenhuma das obras de seu extenso catálogo: sete sinfonias, centenas de obras pra piano, dezenas de concertos, mais de duzentas canções, óperas, cantatas e etc., parecem estar fora da linha de seu profissionalismo absoluto e patamares primorosos dignos dos maiores mestres.

Além do domínio no seu métier de composição, também era um exigente e atencioso professor, duro em seus julgamentos e seleções. A própria classe de alunos, diz por si só, a influência que tinha e o mentor inspirador que era. Entre alguns de seus pupilos (figura 1), além dos supracitados, figuram nomes como: Almeida Prado (1943) e Marlos Nobre (1939). 


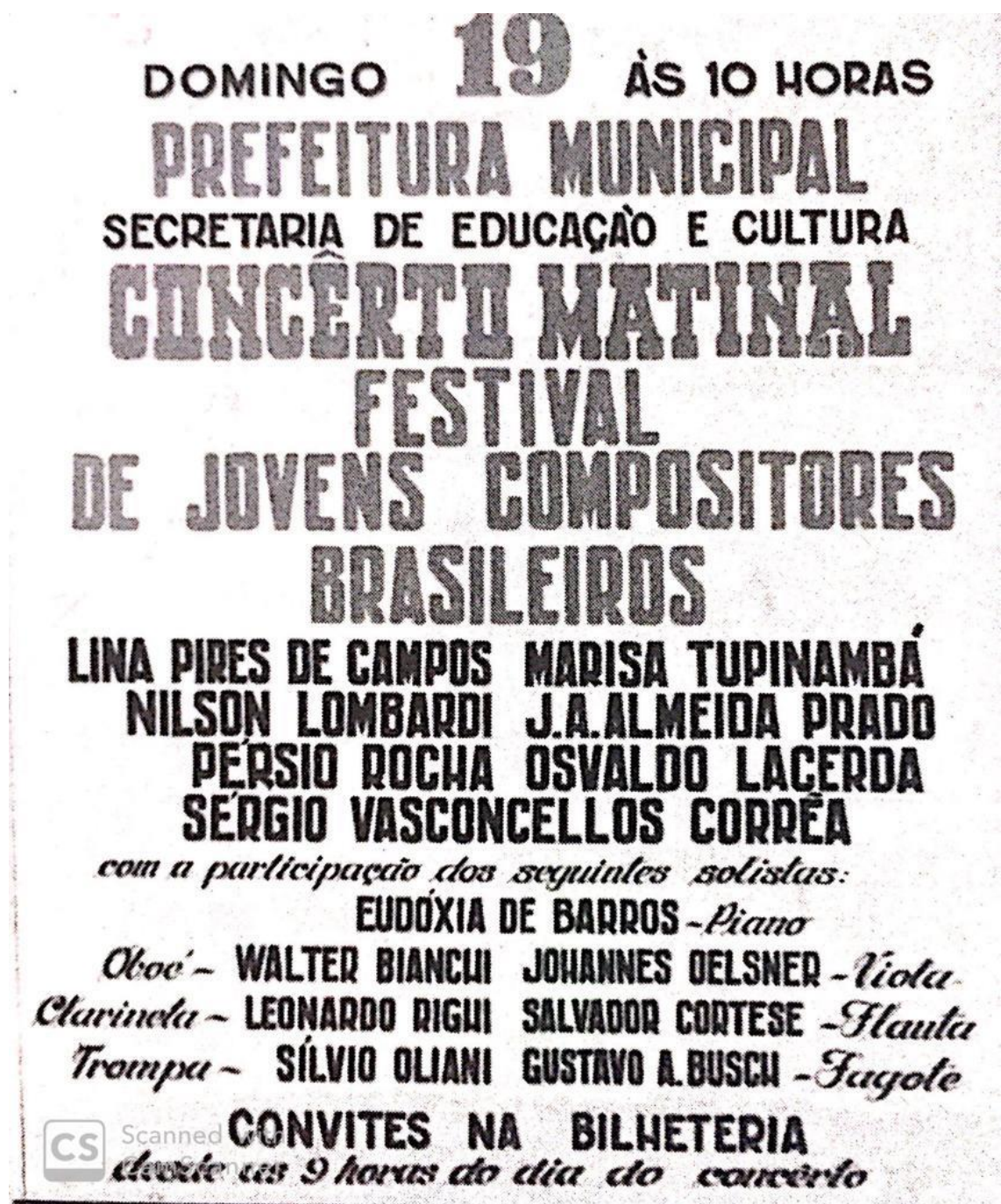

Figura 1: Cartaz do Teatro Municipal de São Paulo, classe de composição de Guarnieri.

Apesar de assumidamente abraçar a causa nacionalista, Guarnieri possuía habilidade e técnica para compor em qualquer estilo. Sempre por opção ou necessidade estilística ou estética. Sua pequena obra para violão, por exemplo, composta por seis peças, podem trazer em si um caráter nostálgico e intimista como no caso da Valsa-Choro n. 1 (1954), mas por outro lado, rígidos saltos, contraponto severo e melodias angulosas como no caso do Ponteio (1944).

Ao desenvolver algumas de suas obras de maneira austera, Mário de Andrade comenta certa vez:

\footnotetext{
"Camargo, você vai sofrer muito em sua vida, porque sua música não se faz amar à primeira vista" (VERHAALEN, 2001, p. 483).
}

Seus 3 Estudos, foram escritos num intervalo de mais de 20 anos, o que talvez possa revelar certa relutância em escrever para o instrumento. Sua interessante maneira de compor 
para o violão, utilizando a mão esquerda como principal referência é descrita num trecho do trabalho de doutorado de Edelton Gloeden:

"Guarnieri, como muitos compositores brasileiros que estamos mencionando, não escrevia para violão com naturalidade. Isto pode ser constatado pelo número reduzido de composições - apenas seis peças - escritas esparsamente, quase todas encomendadas, e de grande dificuldade técnica. O violonista Everton Gloeden (1957) nos informou que Guarnieri tinha como referência principal para abordar a escrita violonística a mão esquerda do piano. Nos anos 50, escreveu a Valsa-Choro no. 1 (1954), bem característica do seu estilo polifônico e o Estudo no. 1 (1958) de transcendental dificuldade para a mão esquerda, dedicado a Isaías Sávio, que fez um belo trabalho de revisão. Ao retomar suas obras para violão nos anos 80 , seu estilo já é mais abstrato. Os Estudos no. 2 e 3 (1983), em parte, retomam as idéias do primeiro, encerrando sua produção violonística com uma sombria Valsa-Choro no. 2 (1986). É interessante notar que há um aumento progressivo da dificuldade técnica no decorrer das três primeiras obras, que é refletido no mesmo modo na retomada dos três trabalhos da década de 80 . Infelizmente, estas obras para violão não atingiram a genialidade de suas mais singelas criações pianísticas, um paradoxo entre os compositores nacionalistas brasileiros mais representativos, que tinham como ideal estético o som da viola sertaneja e do violão. Entretanto, este fato não poderia servir de motivo para que esta importante obra esteja relegada a um segundo plano." (GLOEDEN, 2002).

É interessante notar uma tendência dos compositores nacionalistas deste período ao aproximarem as formas clássicas com as formas instrumentais brasileiras. Relacionando prelúdios e ponteios, canções e modinhas, árias e cantilenas, por exemplo. No caso da classe de Guarnieri, além dele próprio, escreveram ponteios: Lina Pires de Campos, Sérgio Vasconcellos Correa, Theodoro Nogueira e Osvaldo Lacerda, para mencionar alguns.

Ainda sobre as formas instrumentais brasileiras, Lacerda descreve as formas Modinha, Toada e Saramba, em notas da contracapa do disco: Camargo Guanieri: Universo Tropical, Sul América/Unibanco, de 1985.

Sobre a Toada Sentimental - para Annunziatta (sobrinha de Belkiss Carneiro de Mendonça), de Guarnieri: 
"Os dois tipos mais importantes de canção brasileira são a modinha, que é urbana, e a toada, que é rural. Esta última existe em todo o Brasil e reflete peculiaridades musicais de cada região. A toada da chamada "zona caipira" dos Estados de São Paulo e Minas Gerais é uma das mais cativantes, devido a sua peculiar nostalgia, terna e amorosa. Camargo Guanieri, que nasceu em Tietê, numa região onde sempre se cultivou a boa música sertaneja, parece trazer no sangue o espírito da toada, conforme se pode verificar ouvindo as inúmeras obras que escreveu com esse caráter (com ou sem o nome Toada...). A Toada Sentimental, data de 1982, é um excelente exemplo desse gênero, elevado aqui pelo compositor a um alto plano artístico." (LACERDA apud VERHAALEN, 2001, p. 107).

Sobre a peça "Saramba":

"A grande Enciclopédia Delta-Larousse assim define isarambai: Espécie de fandango batido, dançado em geral por pretos (refere-se, evidentemente, ao fandango do sul e sudeste brasileiros, não ao fandango espanhol). O Saramba de Camargo Guarnieri, escrito em 1982, é, que eu saiba, o único exemplo da estilização dessa dança e do emprego desse termo em nossa música erudita. Seu caráter coreográfico é enfatizado pelos ritmos vigorosos e obsessivos, tanto da mão direita como da esquerda." (LACERDA apudVERHAALEN, 2001, p. 126).

Osvaldo Lacerda, um de seus mais constantes alunos, aborda o nacionalismo de uma forma completa e convicta, frente a um ambiente de oposição à essa prática vinda em parte de simpatizantes de Hans-Joachin Koellreutter (1915 - 2005). Em sua obra violonística, incorporou características do violão de seresta urbana e do campo e da viola caipira na sua linguagem, com forte influência guarnieriana, como é possível notar no caso da Moda Paulista (1961), dedicada a Manoel São Marcos. Mas também escreve peças com cores escuras e intimistas, certamente influenciadas por seu mestre, optando inclusive pelas mesmas formas que foram basilares entre os nacionalistas como ponteio e valsa. 


\section{CAPÍTULO 2}

\section{OSVALDO LACERDA: COMPOSITOR}

Nascido em março de 1927, o paulista Osvaldo Lacerda iniciou seus estudos musicais com a mãe, a mezzo-soprano Júlia Costa. Aos onze anos, escreveu sua primeira composição, um Scherzo em Ré Maior para piano. Mas o despertar para a criação não se daria ainda. Passou a se interessar mais pela arte da composição quando começou a estudar harmonia e contraponto com Ernesto Kierski, regente alemão radicado em São Paulo. Em 1949, fundou a Sociedade Paulista de Arte, sendo seu diretor artístico e paralelamente dirigiu o Coral da Sociedade de 1950 a 1953.

Mas o ponto de virada decisivo deu-se em 1952, quando ingressou no curso de composição ministrado por Camargo Guarnieri. Lacerda viria a se tornar um dos principais representantes desta escola composicional brasileira, postura muito incentivada por seu mestre, com quem estudou por uma década (figura 2).

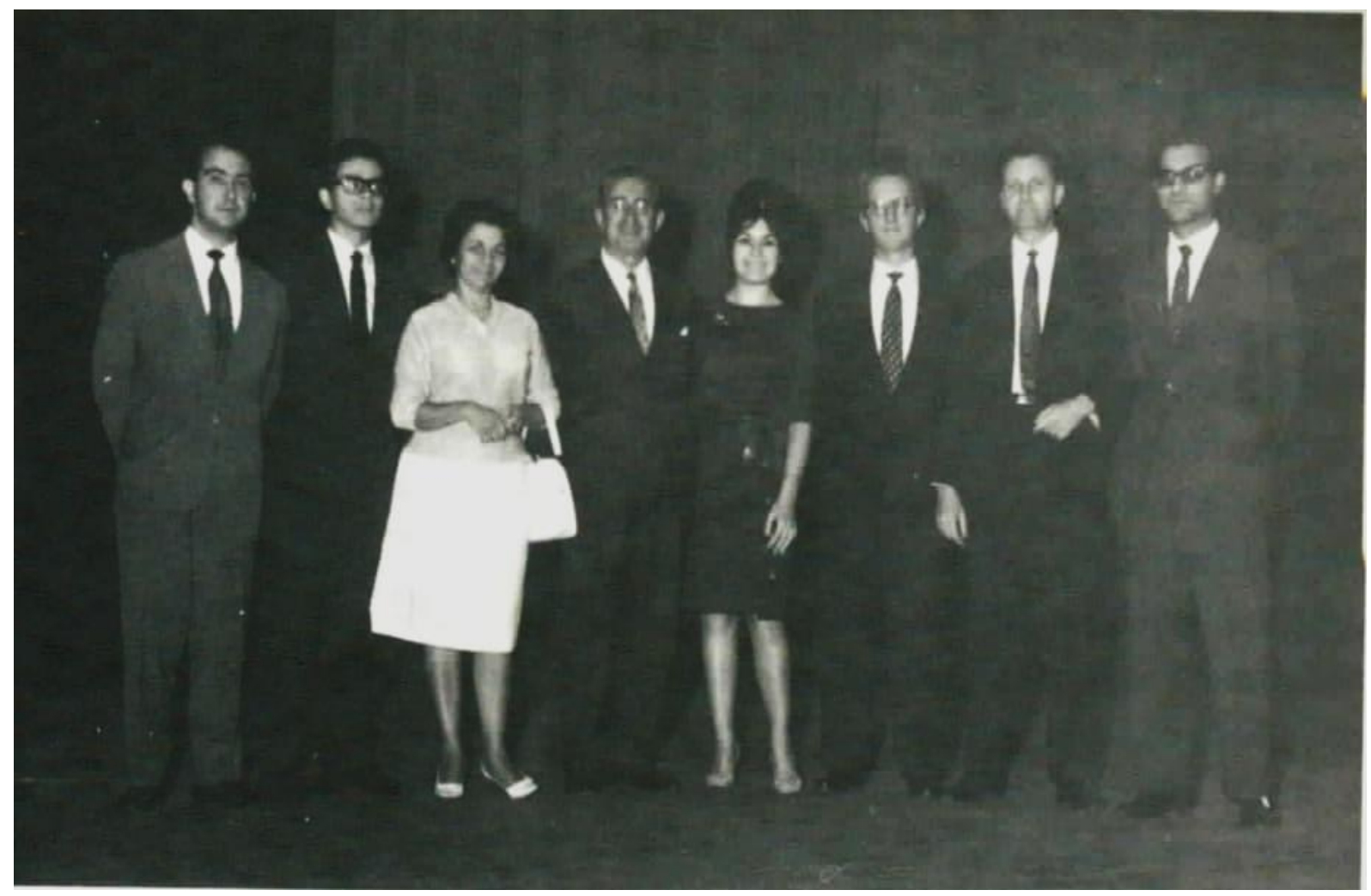

Figura 2: Classe de composição de Camargo Guarnieri (esquerda para direita): Pérsio Rocha, Almeida

Prado, Lina Pires de Campos, Guarnieri, Marisa Tupinambá, Osvaldo Lacerda, Nilson Lombardi e Sérgio Vasconcellos Correa. 
Posteriormente, estudou com Aaron Copland (1900 - 1990) e Vittorio Giannini (1903 - 1966) nos Estados Unidos. (NEVES, José Maria, 1981, p.143). Era um ativo divulgador da música brasileira de concerto, sendo o fundador da Sociedade Paulista de Arte, da Sociedade Pró Música Brasileira e do Centro de Música Brasileira, todos voltados aos estudos e divulgação da nossa música.

Sua produção mais destacada por vários prêmios, possui obras vocais, música de câmara, piano e orquestra. Muitas de suas primeiras peças possuem uma direção neoclássica, como as 15 variações sobre Mulher Rendeira para piano, a Tocatina e Fuga ou ainda as Variações e Fuga ambas para quinteto de sopros. Mas foi com sua tendência nacionalista que o compositor mais se sobressaiu, quando ganhou o primeiro prêmio na Competição Nacional Brasileira com sua suíte orquestral Piratininga (1962). Lacerda também foi premiado com o Melhor Trabalho Sinfônico de 1994, com a peça Cromos para piano e orquestra, e ainda, o troféu Guarani como Secretaria Cultural do Estado de São Paulo, em 1997. Seu catálogo de obras foi publicado em 2006 pela Academia Brasileira de Música sob organização e coordenação de Elizete Higino. E recentemente ampliado, quando sua viúva, a pianista Eudóxia de Barros doou partituras à Mediateca da Fundação Osesp (Sala São Paulo).

Seu nacionalismo era principalmente inspirado por Camargo Guarnieri (figura 3). Seu mestre afirmava que:

“[...] O elemento folclórico deve estar tão integrado na obra quanto na sensibilidade do compositor." (VERHAALEN, Marion. 2001, p.80).

Guarnieri, assim como muitos outros compositores de sua geração, foi influenciado pelas ideias de Mário de Andrade, que certa vez colocou:

“[...] O critério histórico atual da Música Brasileira é o da manifestação musical que, sendo feita por brasileiro ou indivíduo nacionalisado, reflete as características musicais da raça. Onde elas estão? Na música popular.” (ANDRADE, Mário de. 1972, p.20). 


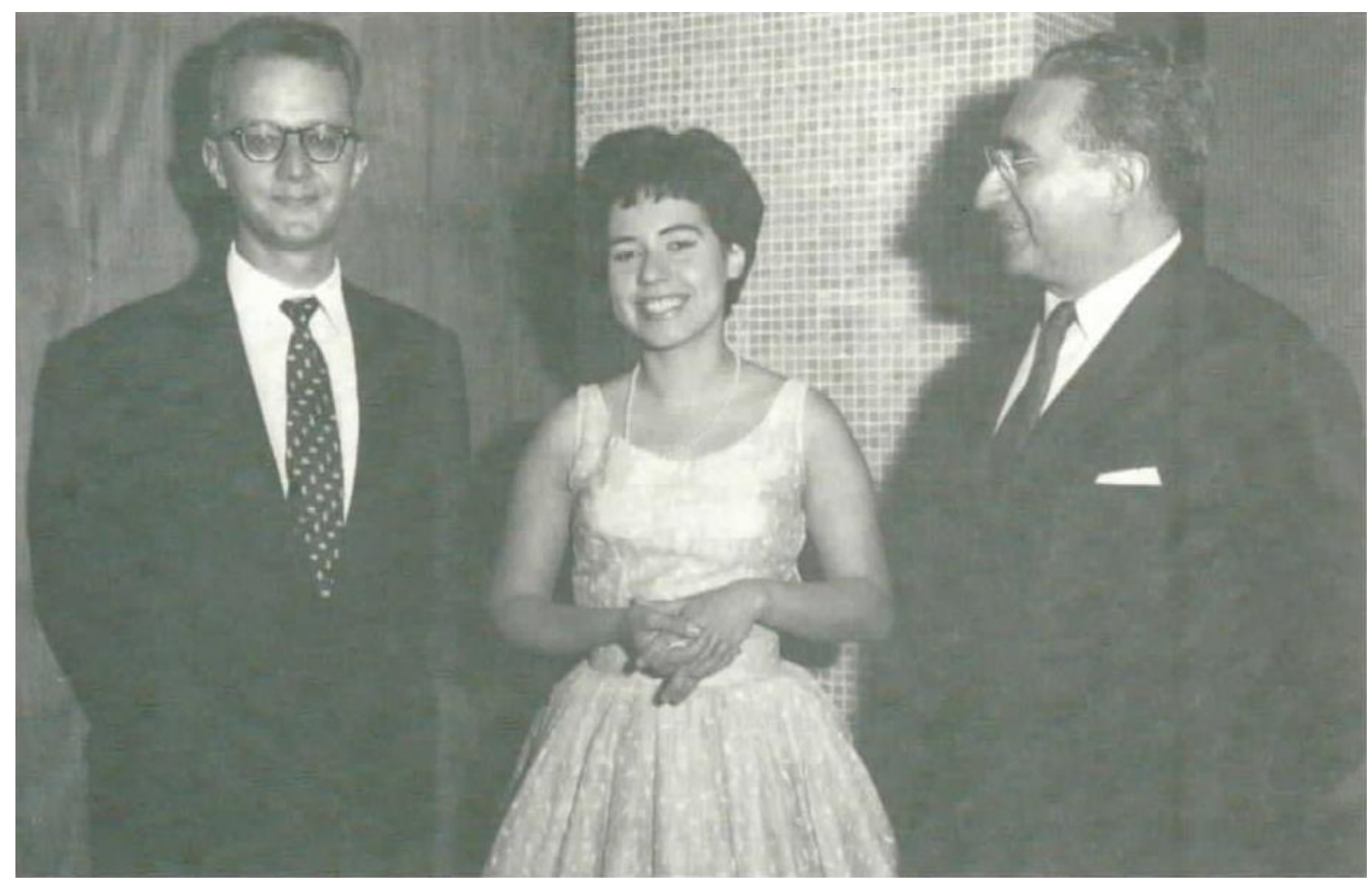

Figura 3: Osvaldo Lacerda, Eudóxia de Barros e Camargo Guarnieri.

Guarnieri muito creditou e encorajou Lacerda. Seu entusiasmo pela música e cultura brasileira era muito notado por seu aluno. Lacerda teceu alguns interessantes comentários sobre seu professor:

[...] Nada mais longe da verdade; o que existe aí é uma grande confusão entre causa e efeito. A realidade é esta: não é pelo fato de os alunos estudarem com Guarnieri é que compõem música brasileira, mas é por comporem música brasileira que estudam com Guarnieri. [...] O que Guarnieri faz, na realidade, com seus alunos, é conscientizá-los da problemática da nossa música, e induzi-los a aprofundar o conhecimento e manejo da mesma. Consegue esse objetivo por meio de sábios conselhos, pelo ensino da composição e pelo exemplo de sua própria obra. [...] o que o compositor pretende, acima de tudo, é fazer-se inteligível ao próximo e, para isso, precisa revestir sua inspiração de uma forma adequada ao tempo e ao lugar em que escreve.

Esse princípio deve ser reconhecido pelo compositor, porque se ele procura exprimir-se de maneira estranha ao seu ambiente e, portanto, estranha sua própria natureza, estará sendo, consciente ou inconscientemente, insincero. [...] Tanto o gênio musical como o talento anônimo que, no mais recôndito rincão do país, criam uma bela canção folclórica, pertencem inexoravelmente à mesma nação. Tanto esses dois extremos como os que entre eles se situam são elos da mesma cadeia, são manifestações, apenas em 
graus diferentes, do mesmo desejo e da mesma natureza de expressão artística. [...] A perfeição formal, pois, pode ser encontrada na

mais complexa das sinfonias como na mais simples das melodias folclóricas, vocal, [Guarnieri] corrige os erros de prosódia, chama a atenção para a limitação das vozes, e ensina a boa colocação das vogais. Na composição para canto e piano, cuida que o piano não seja um mero harmonizador, mas um verdadeiro parceiro do canto (o que é conseguido, muitas vezes, pelo emprego da técnica contrapontística). Chega-se, assim, a uma ideal integração dos três elementos da canção: texto, voz e instrumento. (LACERDA apud SILVA, 2001, p. 57-67).

Lacerda foi professor da Escola Municipal de Música de São Paulo, (cargo do qual se aposentou em 1992) e ocupava a cadeira de número 9 da Academia Brasileira de Música. Seus livros Compêndio de Teoria Elementar da Música, Exercícios de Teoria Elementar da Música, Curso Preparatório de Solfejo e Ditado Musical e Regras de Grafia Musical, estão até hoje catalogados, sendo adotados no Brasil e em Portugal.

Pessoalmente, tive contato com sua obra coral em especial, no período em que fui coralista do Coro de Câmara Comunicantus e do Coral da ECA/USP ${ }^{1}$, então na época coordenado pelos professores Marco Antonio Silva Ramos, Susana Igayara e Ricardo Ballestero. Estudamos várias de suas obras (dentre elas: A Primeira Missa e o Papagaio, Uníssono, Missa Ferial) e ainda em 2014, sua peça Romaria para coro foi gravada pelo Choir of Gonville and Cairus Choir (Cambridge - UK), com regência de Geoffrey Webber, pontuando como sua obra vem sendo disseminada atualmente.

\footnotetext{
${ }^{1}$ O Coro de Câmara Comunicantus, projeto conjunto com a Pró-reitora de Graduação da USP, é formado por 28 coralistas bolsistas e um pianista, alunos de graduação de diversos cursos da USP, com a maioria de estudantes de música. Desde agosto de 2013, tem desenvolvido um repertório próprio para a sua formação, como parte da experiência dos alunos que pretendem se profissionalizar no Canto Coral.
} 


\section{1: O VIOLÃO NA OBRA DE OSVALDO LACERDA}

O violão também teve atenção de Lacerda, embora sua obra para o instrumento seja pequena. São três peças para violão solo: Ponteio (1959), Valsa (1961), Moda Paulista (1961), dedicadas à Isaías Sávio, Maria Lívia São Marcos e Manoel São Marcos, respectivamente, grandes expoentes do violão brasileiro. No âmbito da música de câmara: as 3 canções para canto e violão e as versões inacabadas das obras Cantilena, Poemeto e Toccatina, originais para flauta e piano, onde Lacerda inicia a versão para flauta e violão. Essas peças ainda não conquistaram um espaço nos programas regulares de concertos, sendo pouquíssimo conhecidas. Sobretudo pela dificuldade de acesso às partituras manuscritas, como já vimos. Apesar de existirem gravações dessas obras, duas delas realizadas para o programa Violão com Fabio Zanon, da Rádio Cultura, e uma delas registrada em LP, por Maria Lívia São Marcos na década de 60. As canções seguem sem gravação comercial.

É importante mencionar que a prática do violão de concerto e seu repertório no Brasil, estava em seu estágio inicial, como podemos observar abaixo da tabela elaborada e revisada para este trabalho por Edelton Gloeden de 1944 a 1970, mostrando a produção brasileira na época quando foram criadas as obras para violão de Osvaldo Lacerda. (GLOEDEN, 2002).

\begin{tabular}{|c|c|c|}
\hline Ano & Autor & Título \\
\hline \multirow[t]{2}{*}{1944} & Camargo Guarnieri & Ponteio \\
\hline & Radamés Gnattali & Serestas p/ flauta., violão. e quarteto de cordas \\
\hline 1945 & Savio, I & 3 Estudos \\
\hline \multirow[t]{2}{*}{1946} & Guerra Peixe, C. & Suite \\
\hline & Katunda, E. & $\begin{array}{l}\text { Negrinho do Pastoreio: Cantata } \mathrm{p} / \text { vozes } \\
\text { femininas a capella ou com acompanhamento } \\
\text { de flauta, violão e percussão }\end{array}$ \\
\hline 1947 & Savio, I. & Hesitação \\
\hline 1949 & Th. Nogueira, A. & Ponteio \\
\hline \multirow[t]{4}{*}{1951} & Gnattali, R. & Tocata em ritmo de samba $n^{o} 1$ \\
\hline & Gnattali, R. & $\begin{array}{l}\text { Concertino } n^{o} .1 \text { (Concerto de Ipanema) } \mathrm{p} / \\
\text { violão e orquestra. }\end{array}$ \\
\hline & Gnattali, R. & Concertino $n^{o} .2 \mathrm{p} /$ violão e orquestra \\
\hline & Katunda, E. & $\begin{array}{l}\text { Pacto da Paz p/ soprano, mezzo soprano, } \\
\text { contralto, barítono, baixo, coromisto, piccolo, } \\
\text { flauta, violão, } 2 \text { violas, percussão }\end{array}$ \\
\hline
\end{tabular}




\begin{tabular}{|c|c|c|}
\hline & Villa-Lobos, H. & Concerto $\mathrm{p} /$ violão e pequena orquestra \\
\hline 1953 & Mignone, F. & $\begin{array}{l}\text { Modinha, Repinicando, Minueto Fantasia e } \\
\text { Chôro }\end{array}$ \\
\hline \multirow[t]{2}{*}{1954} & Camargo Guarnieri, $\mathrm{M}$. & Valsa-Chôro $n^{o} .1$ \\
\hline & Gnattali, R. & $\begin{array}{l}\text { Suite Popular Brasileira p/ violão, piano e } \\
\text { percussão }\end{array}$ \\
\hline \multirow[t]{2}{*}{1955} & Th. Nogueira, A. & Valsa-Chôro $n^{o} .2$ \\
\hline & Krieger, E. & Estudo \\
\hline \multirow[t]{2}{*}{1957} & Th. Nogueira, A. & Canto caipira $n^{o} .5$, Brasilianas $n^{o}$ s. 1,2 e 3 \\
\hline & Gnattali, R. & $2^{a}$. Sonatina $\mathrm{p} /$ violão e piano (ou cravo) \\
\hline \multirow[t]{2}{*}{1958} & Camargo Guarnieri, $\mathrm{M}$. & Estudo $n^{o} .1$ \\
\hline & Th. Nogueira, A. & Brasilianas $n^{o}$ s. 4 e 5, Valsas-Chôro $n^{o}$ s. 4 e 5 \\
\hline \multirow[t]{4}{*}{1959} & Lacerda, $\mathbf{O}$. & Ponteio \\
\hline & Th. Nogueira, A. & 12 Improvisos, 4 Serestas, Valsa-Chôro $n^{o} .1$ \\
\hline & Vasconcellos Corrêa, S. & Valsa-Chôro $n^{o} .1$ \\
\hline & Gnattali, R. & Sonata $\mathrm{p} /$ flauta e violão \\
\hline 1960 & Th. Nogueira & Valsa-Chôro $n^{o} .3$ \\
\hline 1961 & Lacerda, $\mathbf{O}$. & $\begin{array}{l}\text { Moda Paulista } \\
\text { Valsa }\end{array}$ \\
\hline \multirow[t]{2}{*}{1963} & Katunda, E. & Suite Nazareth \\
\hline & Escobar, A. & Prelúdio \\
\hline \multirow[t]{3}{*}{1966} & Guerra-Peixe & Prelúdio $n^{o} .5$ (Ponteado Nordestino) \\
\hline & Gnattali, R. & Sonatina $\mathrm{p} /$ violoncelo e 2 violões \\
\hline & Nobre, $\mathrm{M}$. & Modinha p/ voz, flauta e violão \\
\hline \multirow[t]{4}{*}{1967} & Gnattali, R. & 10 Estudos \\
\hline & Gnattali, R. & $\begin{array}{l}\text { Concertino } n^{o} .3 \text { (Concerto de Copacabana) } \mathrm{p} / \\
\text { violão, cordas, flauta, tímpanos }\end{array}$ \\
\hline & Gnattali, R. & $\begin{array}{l}\text { Concertino } n^{o} .4 \text { (Concerto à Brasileira) p/ } \\
\text { violão e cordas }\end{array}$ \\
\hline & Mahle, E. & 2 Peças p/ canto e violão \\
\hline \multirow[t]{3}{*}{1968} & Lacerda, $\mathbf{O}$. & $\begin{array}{l}\text { Três Canções p/ voz e violão } \\
\text { 1. As Dádivas (Guilherme de Almeida) } \\
\text { 2. Vácuo (Guilherme de Almeida) } \\
\text { 3. Saudade (Diversos Autores) }\end{array}$ \\
\hline & Nobre, M. & O Dia da Graça p/ voz e violão \\
\hline & Gnattali, R. & Concerto p/ 2 violão, oboé e cordas \\
\hline
\end{tabular}




\begin{tabular}{|c|c|c|}
\hline \multirow[t]{3}{*}{1969} & Guerra Peixe, C. & $\begin{array}{l}\text { Prelúdio } n^{\circ} .1 \text {, Sonata, } 2 \text { Canções e } \\
\text { Mãe d'Água p/ voz e violão }\end{array}$ \\
\hline & Th. Nogueira, A. & Concertino $\mathrm{p}$ / violão e orquestra \\
\hline & Gnattali, R. & Sonata p / violoncelo e violão \\
\hline \multirow[t]{5}{*}{1970} & Guerra Peixe, $\mathrm{C}$. & $\begin{array}{l}\text { Prelúdios } n^{o} \text { s. 2, } 3 \text { e 4; Dueto Característico } \mathrm{p} / \\
\text { violino e violão; Galope p / violino, viola, } \\
\text { violão, } 2 \text { flautas e bateria; De Rabeca e Viola } \\
\text { p / violino e violão }\end{array}$ \\
\hline & Mignone, F. & 12 Estudos \\
\hline & Mignone, F & 12 Valsas Brasileiras em forma de Estudos \\
\hline & Souza Lima, J. de & Cortejo \\
\hline & Pereira da Silva, A. & Ponteio \\
\hline
\end{tabular}

Num rápido exame desta tabela, podemos constatar que o repertório violonístico brasileiro na época quando as obras de Osvaldo Lacerda foram escritas, estava totalmente imerso no movimento nacionalista com predomínio de compositores ligados à escola guarnieriana. Somente a partir de 1974, quando surgem as obras de Marlos Nobre (Momentos I), Almeida Prado (Livro das Seis Cordas) e de Edino Krieger (Ritmata), começa a diversidade estética vinda de uma geração com olhares para os movimentos vanguardistas da época.

As raras gravações e performances, são uma outra razão para que em parte estas obras não pareçam muito idiomáticos a priori, apresentando trechos críticos de difícil execução. Característica essa não apenas da música de Lacerda, mas também de compositores não violonistas como Guarnieri por exemplo, onde há um evidente paralelo e forte influência. $\mathrm{O}$ que pode soar paradoxal, visto que o violão é um instrumento tão presente na cultura popular brasileira. Por outro lado, a obra para violão de Villa-Lobos a essa altura, estava ganhando a notoriedade da posição que ocupa até hoje. Seus 12 Estudos (1928) e os 5 Prelúdios (1940) esperaram muitos anos para tornarem-se as obras brasileiras mais tocadas nacional e internacionalmente.

Todavia, esse panorama vem se atualizando, com muitas obras conquistando cada vez mais lugar sólido no repertório de concerto e nas salas de aula. Como é o caso dos 12 Estudos para violão e as 12 Valsas Brasileiras em Forma de Estudos de Francisco Mignone (ciclos com o mesmo número dos consagrados 12 Estudos de Villa-Lobos), compostos em 1970, e muitas outras pequenas peças de Guerra-Peixe, Almeida Prado, Marlos Nobre e de toda a escola de Guarnieri. 


\section{2: BREVE ENTREVISTA COM MARIA LIVIA SÃO MARCOS}

Seguimos com algumas impressões de uma breve entrevista que nos foi concedida por Maria Lívia São Marcos (1942)², a primeira intérprete da obra de Osvaldo Lacerda.

1. Duas peças de Osvaldo Lacerda são dedicadas a você e a seu pai. Como se deu o seu contato com a obra para violão solo do compositor?

"Eu era aluna de Osvaldo Lacerda e ele quis escrever algo para o violão. Começou com a Valsa (1961), obra maravilhosa que há 5 anos atrás gravei em um projeto que não deu certo, fiz algumas modificações, orientada pelo Paulo Bellinati.”

2. Como foi o processo de gravação da Moda Paulista?

"A Moda Paulista foi após a Valsa, ele pensava fazer efeito de viola caipira com os acordes iniciais, o que seria ótima ideia se o violão tivesse cordas de aço, mas com o nylon não gerou o efeito que ele quis. Na gravação de 5 anos atrás tentei imitar a viola com melhor resultado."

3. Porque, na sua opinião, a obra para violão de Osvaldo Lacerda não é tão tocada e difundida como suas peças para piano e coro?

“Acho que a razão das obras de Osvaldo Lacerda não serem tocadas é em primeiro lugar a dificuldade técnica de execução. Em segundo, infelizmente no Brasil os violonistas não tocam o repertório do instrumento, nunca ouço em concerto uma sonata de Sor ou um simples prelúdio de Villa-Lobos, uma pena! Cada um quer tocar suas próprias composições. Estranho que isso aconteça só no violão, não vejo um pianista que não toque o repertório preferindo suas próprias composições. Enfim, hoje se toca muito bem, mas a parte da cultura da música e do instrumento está relegada a quase nada. Espero que pude responder às tuas questões, bom trabalho e muita sorte."

\footnotetext{
${ }^{2}$ Maria Livia São Marcos é uma violonista brasileira que se formou no Conservatório Dramático e Musical de São Paulo e lecionou no Conservatório Carlos Gomes e no Conservatório de Música de Genebra (Suíça) por mais de trinta anos. Teve contato direto com Osvaldo Lacerda. Segue seu breve relato sobre o contato com as obras, algumas delas dedicadas a ela e seu pai, Manoel São Marcos.
} 


\section{CAPÍTULO 3}

\section{APONTAMENTOS TÉCNICO-INTERPRETATIVOS}

Para qualquer fim de nota ou referência, as partituras manuscritas estarão anexadas ao fim deste trabalho. Este capítulo irá apresentar breves notas interpretativas das peças e algumas opções/sugestões de execução, por um viés mais prático, que pode tornar o estudo mais proveitoso e fazer com que alguns trechos rendam melhor musicalmente.

Estas pequenas observações tornam-se intrigantes, visto o rigor da escrita de Lacerda. Neste trecho de uma carta escrita ao trompetista Fernando Dissenha, fica bastante claro sua cuidadosa visão sobre leitura e performance. O intérprete deve, segundo Lacerda, seguir rigorosamente as indicações nas partituras, assim trazendo à tona o real sentido da obra.

Tarefa que se mostra ainda mais desafiadora, devido ao abundante número de indicações e grande detalhamento em sua música.

"Quanto as minhas peças, dou-lhe sinceros parabéns pela belíssima execução de mestre, com um som puro e preciso; pelos pianos (p) bonitos, "redondos" e expressivos; pelos fortes não-agressivos; e pela interpretação correta, obediente à partitura (coisa-rara!), captadora do que, na falta de melhor palavra, se chama de "o sentido" da obra. Parabéns por tudo, e muito obrigado! [...].

Osvaldo Lacerda."

(LACERDA, Osvaldo apud RODRIGO, André Guimarães, 2016).

\section{1: AS PEQUENAS FORMAS}

Osvaldo Lacerda trabalhou pequenas formas brasileiras definidas em sua obra para violão: o ponteio, a valsa e a moda. Seguem suas definições para entendê-las melhor numa análise de Mario de Andrade assim as apresenta em seu Dicionário Musical Brasileiro:

Ponteio (Pontear): “[...] Colocar os dedos sobre (as cordas), no lugar onde estão os pontos ou tastos, a fim de produzir as diversas entoações, tanger a viola na parte cantante. - o que parece indicar que pontear é apenas executar, dedilhar um trecho musical, no violão ou na viola [...]. Como substantivo: 'com um violeiro que no botar versos e no ponteá não havia outro. [...] tempera a prima na afinação sorta um repinicado 
e começa a pontear'. Prelúdio, Interlúdio”. (ANDRADE, Mário de. 1989, p.406-7 apud GOMES, L. Contos Populares. (V.1, 1931) p. 96 e 99).

Valsa: "Dança em compasso ternário e andamento variado (rápido morado ou lento)

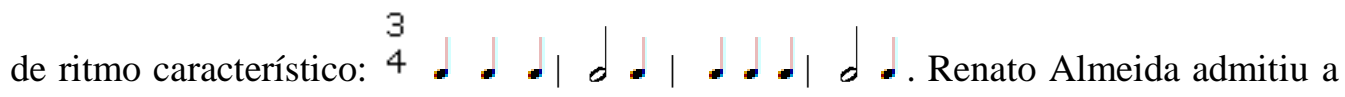
origem francesa da dança, no século XVI. "[...] Amaneirou-se no Brasil, onde entrou por volta de 1837, ficou sestrosa, sofreu a influência das modinhas e adaptou-se ao choro nacional. Se guardou as suas características fundamentais [...] abrasileirou a sua melodia e se tornou uma forma de canção sentimental, que é hoje a mais comum dos compositores do gênero." (ANDRADE, Mário de. 1989, p.548-9; apud ALMEIDA, Renato. História da Música Brasileira. (DM-MA, 1942) p. 184). Valsado, walsa, walsar. [...] Acho que por aqui as músicas não sendo 'contra-danças' (cateretê, recortado, canaverde) ou não sendo quadrilha ou mazurca são sempre 'valsas'. 'Valsear', 'valseado', nas explicações que me dão da coreografia dos recortados, quer dizer que os pares se abraçam, rodam ou fazem qualquer jeito de 'balanceado' com o corpo. E assim se dança tudo, desde que não seja contradança, quadrilha e mazurca...[...]".

Moda: "Poesia cantada com acompanhamento especialmente de viola e às vezes de violão. É o conceito popular caipira que nas minhas viagens pude identificar. O caipira distingue com certa firmeza o que seja uma moda. Esta se distingue por ser o reconto dum caso qualquer mais ou menos sensacional, ou dum fenômeno importante da vida quotidiana, historiado. Assim é bem raro que um cantador caipira legítimo, cante como sendo uma moda uma série de quadras soltas. A isto chamará de cantiga, toada, samba, etc. A moda entre os caipiras é perfeitamente o que os nordestinos chamam de romance. A diferença mais comum entre romance e moda, é que esta no geral é composta de quadras, ao passo que o romance raramente emprega a quadra, apresentando de preferência a sextilha ou a décima. [...]. (Figura 4)" 
Exemplo do Jorginho do Sertão:

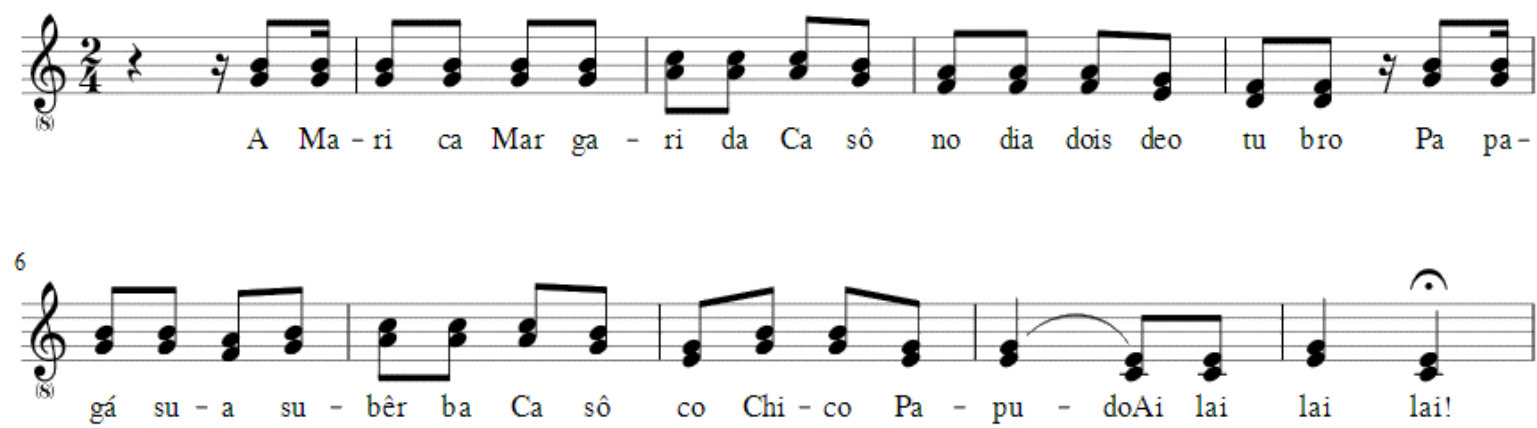

Figura 4: Estribilho instrumental em toque rasgado. Moda-de-viola colhida por Mário de Andrade do caipira João Gabriel, em São Carlos (SP).

Texto: “ A Maria Margarida/ Casô nu dia doi de otubro;/ P’a pagá sua suberba/ Casô c’o Chico Papudo./ Ai lai-lai, lai!...// Incontrô suas companhêra./ -Adeus, cumo vam' di sorte?/ -Desd'u dia que eu casei,/ Sempre semp' desejo a morte!/ Ai lai-lai, lai!...// Fosse coisa qui eu pudesse,/ Eu fazia negoço certo:/ Dav'u Chico p'a Jorgina/ I eu ficav'c'o Juão Roberyto!/ Ai lai-lai, lai!...// Agora num tem remédio/ Seim eu num dança c‘o Chico,/ Eu já falei pra ele:/ Qu'eu danço e vancê arripica./ Ai lai-lai, lai...!// Maginei a minha vida:/ Fico satisfeit' cum tudo!/ Eu agora já sô dono/ Du Chico c'o papo i tudo!/ Ai lai-lai, lai!"

(A Jorgina era papuda também, esclarece o cantador.) (Arrepicar é um processo de sapateado dos cateretês)". (ANDRADE, Mário de. 1989, p.406-7; p.548-9; p.342-3).

\section{2: O PROCESSO DE DIGITAÇÃO}

Em obras como estas, de compositores não-violonistas, é interessante notar os diferentes processos de digitação que surgem no decorrer do estudo e preparo das peças. Por ser uma ciência ainda sem uma literatura especializada, com casos de inúmeras possibilidades que vão e ainda, por vezes muito pessoal. Um mesmo trecho pode apresentar diversas opções de dedilhado, cabendo ao intérprete fazer a decisão que seja mais adequada às suas possibilidades técnicas, à estética em questão e que também favoreça as indicações musicais.

No caso das peças solo - Ponteio (1959), Valsa (1961) e Moda Paulista (1961) - isso se expressa prática e vividamente. As primeiras digitações realizadas pelos violonistas aos quais estas obras foram dedicadas, Isaías Sávio e Manoel São Marcos, são completamente distintas 
das que são apresentadas neste trabalho, mesmo os rascunhos feitos na Valsa (1961) por Edelton Gloeden, seja por opções de favorecimento a determinado trecho melódico ou por soluções práticas embasadas em resultados sonoros. É preciso registrar que a preferência por abordagem polifônica, característica do estilo guarnieriano refletidas nas obras de Lacerda, exercem uma maior sobrecarga de trabalho da mão esquerda a qual os procedimentos de digitações deste trabalho estão totalmente concentrados. A ação da mão direita voltada à realização de planos sonoros resultantes da escrita polifônica, se aproxima de um tratamento utilizado nas obras de Bach em versões para violão.

Não há aqui um desejo de solucionar os trechos mais críticos de forma definitiva ou sugerir que há digitações melhores que outras. A experimentação e busca por novas soluções faz parte da metodologia de trabalho de todo músico que se depara com trechos críticos ou desconfortáveis no momento do estudo. Mesmo digitações consagradas, por vezes são singelamente ajustadas para condições físicas ou motoras diferentes. A ideia é sempre priorizar o pensamento composicional e estilístico determinado pelo compositor.

O próprio processo digitação das peças constitui um minucioso trabalho de análise, relacionando a preparação e execução. Uma análise prática (RINK, 2006), pois a escolha dos timbres e registros das cordas, da formação das escalas e acordes, e das regiões do instrumento onde propiciam as dinâmicas mais adequadas, são todos pontos observados durante o processo de estudo e dedilhado das obras. Contudo, cabe apontar alguns pontos em que a experiência com o instrumento proporciona resultados melhores que o texto musical propriamente escrito, sem alterar nenhuma função de acorde ou grupo escalar. Essa é uma prática muito comum, quando os compositores têm a possibilidade de ouvir e trabalhar suas próprias obras com os intérpretes. Inclusive são trechos que podem proporcionar uma interessante discussão e interação entre professor e aluno, na melhor escolha do dedilhado a ser utilizado, por via de argumentos e práticas do que melhor se encaixa nas condições fisiológicas e técnicas do executante.

Todos esses trechos com digitações alternativas aparecem discretamente grafadas com um asterisco nas partituras editadas.

Nas partituras revisadas e digitadas deste trabalho, foi utlizada a seguinte convenção: quando o símbolo de indicação de pestana $(C)$ ou meia pestana $(\mathbb{C})$ está sobre uma nota ou acorde e não apresenta uma linha que a estenda, significa que ela dura somente o tempo ou acorde em questão. 
Não serão utilizados dedos-guia nos bordões (cordas (6), (5) e (4)) para evitar chiados da mão esquerda.

Dito isto, discutiremos algumas passagens neste capítulo com mais de uma opção de execução ao instrumento.

\section{3: NOTAS INTERPRETATIVAS E DEDILHADOS ALTERNATIVOS}

Serão apresentadas algumas possibilidades de execução em determinados trechos das obras de Lacerda. A maneira de intervir no texto musical original buscando possibilidades que resultem melhor foi baseada no trabalho de doutorado de Edelton Gloeden. (GLOEDEN, Edelton. 12 valsas brasileiras em forma de estudos para violão de Francisco Mignone: um ciclo revisitado. ECA-USP, São Paulo, 2002).

\section{4: VIOLÃO SOLO}

Aluno por mais de uma década da classe de composição de Guarnieri, Lacerda deixa claro em sua obra o processo de criação e apontamentos de seu mestre. Primeiramente num aspecto formal, quando Lacerda escreve um Ponteio e uma Valsa. Formas que Guarnieri também abordou em sua breve obra para violão solo, respectivamente em 1944 e 1954.

\section{PONTEIO (1959) - NOTAS INTERPRETATIVAS}

\section{à Isaías Sávio.}

Sem pressa, cantando, $m f$ - Forma de prelúdio, 56 compassos.

O Ponteio de Osvaldo Lacerda talvez seja a obra do repertório violonístico com mais traços composicionais de seu período sob a orientação de Guarnieri. Figura num ponto médio de dificuldade e tempo de assimilação, acima da Moda Paulista e abaixo da Valsa. A peça possui um senso de direção certeiro, um longo discurso com linhas melódicas severas e muito presentes nos baixos, cromatismo intenso e contraponto constante. Num fluxo de colcheias que se mantém praticamente até o final da obra (figura 5). Características também presentes no Ponteio de Guarnieri, escrito em 1944 (figura 6). 


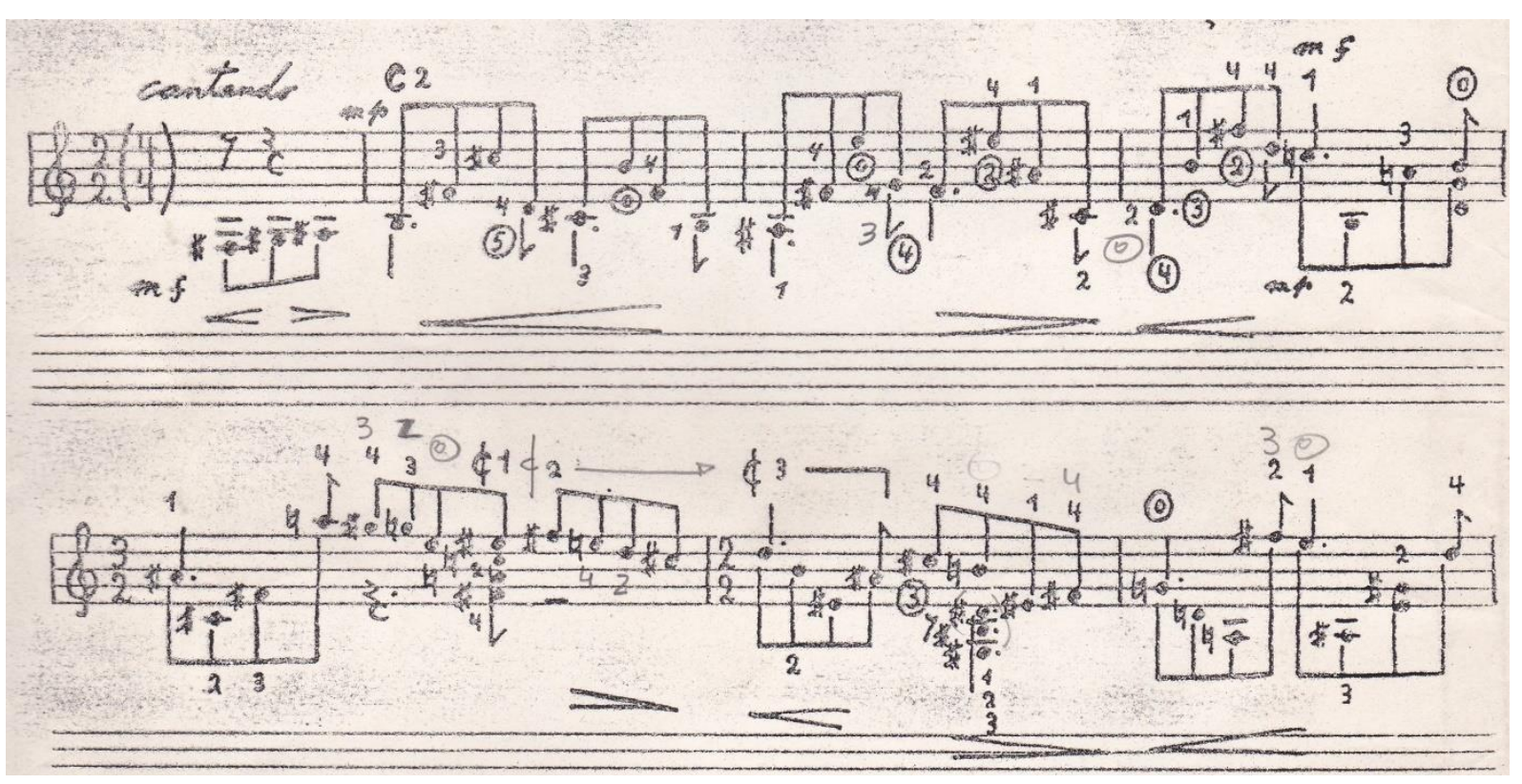

Figura 5: Compassos iniciais do Ponteio de Lacerda.

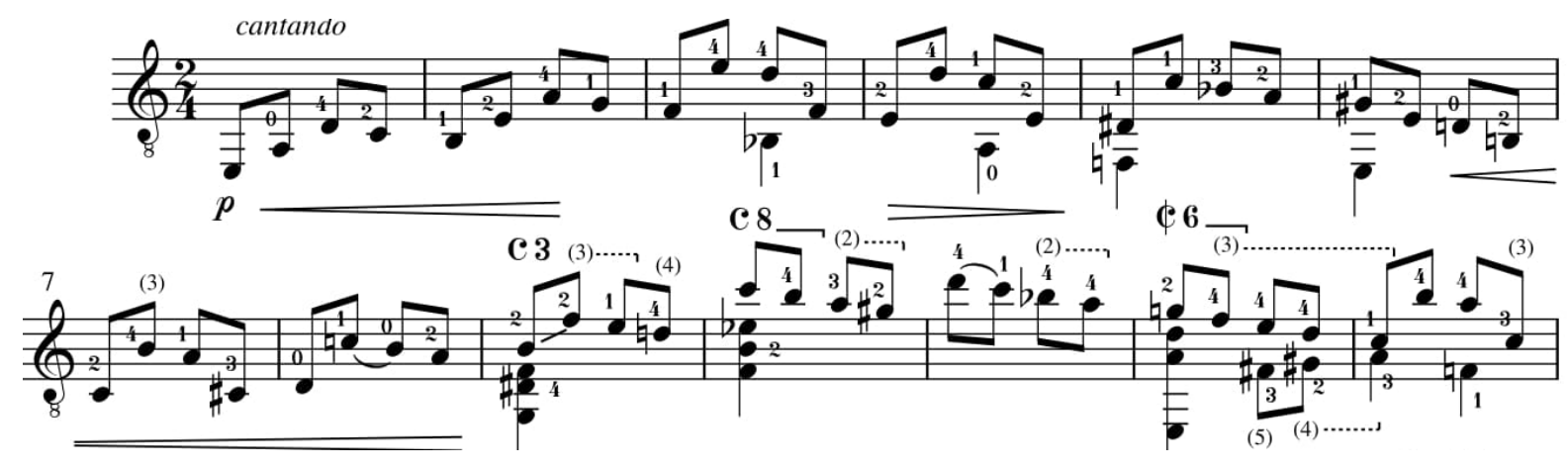

Figura 6: Ponteio de Guarnieri, fluxo de colcheias com melodia na região grave e forte cromatismo. 
Logo ao início da peça, é interessante perceber a função de apagamento exercido pela meia pestana do compasso 5 (figura 7).

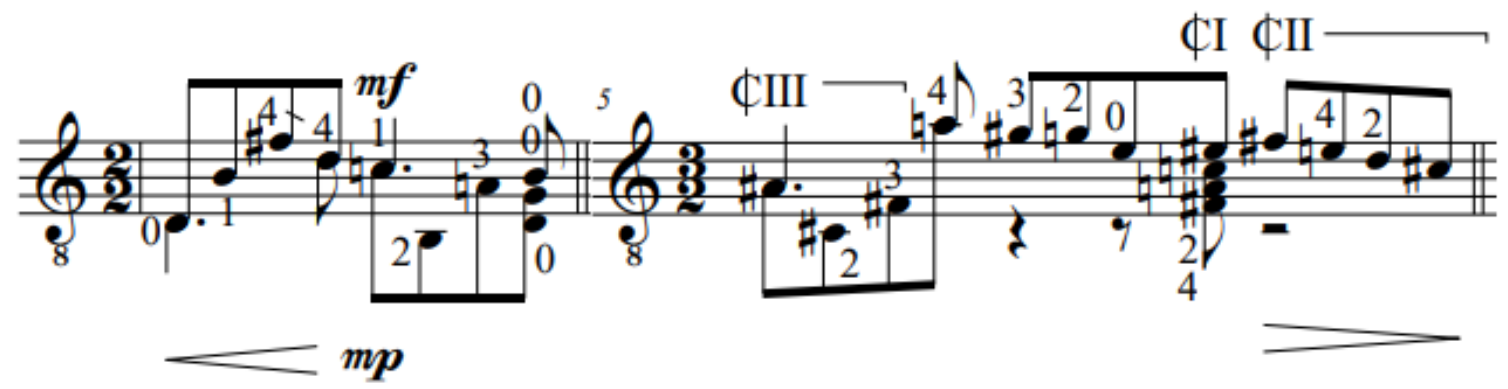

Figura 7: Meia pestana na terceira posição, exercendo a função de apagar as cordas soltas do compasso anterior.

Aqui é apresentada uma digitação alternativa para o compasso 6, sem o uso de pestana (figura 8).

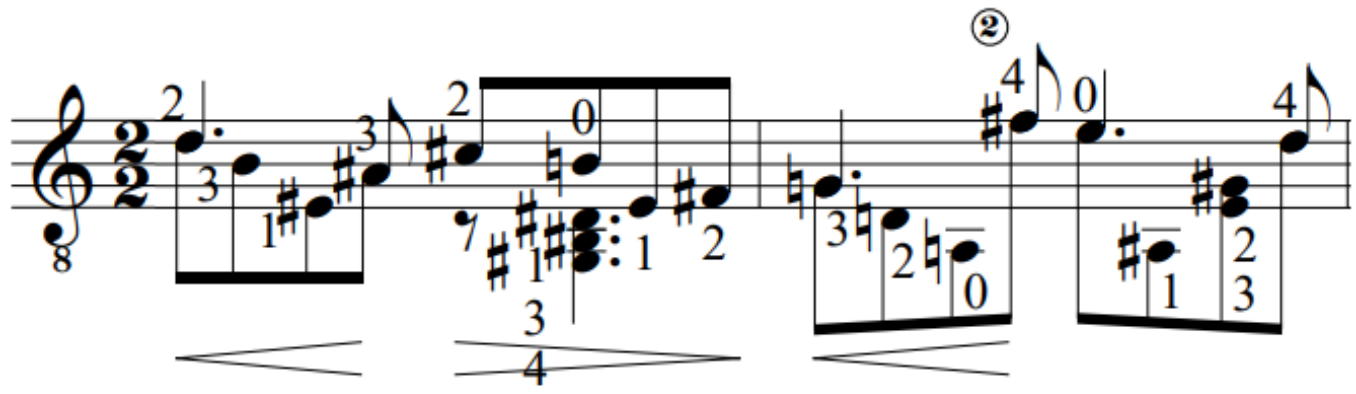

Figura 8: Ponteio, compasso 6. 
Nesta complexa passagem, o movimento dos baixos está em evidência. No primeiro tempo do compasso 13, lê-se um acorde de Dó Maior (Sol, Do, Mi, Sol). Neste momento, cabe suprimir a nota Mi da região aguda, assim não é necessário mudar de posição ouvindo-se o acorde numa região plena e confortável do instrumento. Essa alteração não configura uma grande perda em questões musicais, pois trata-se de uma passagem que dura apenas o tempo de uma colcheia e a terça do acorde (a nota Mi) está presente nos baixos (figura 9).

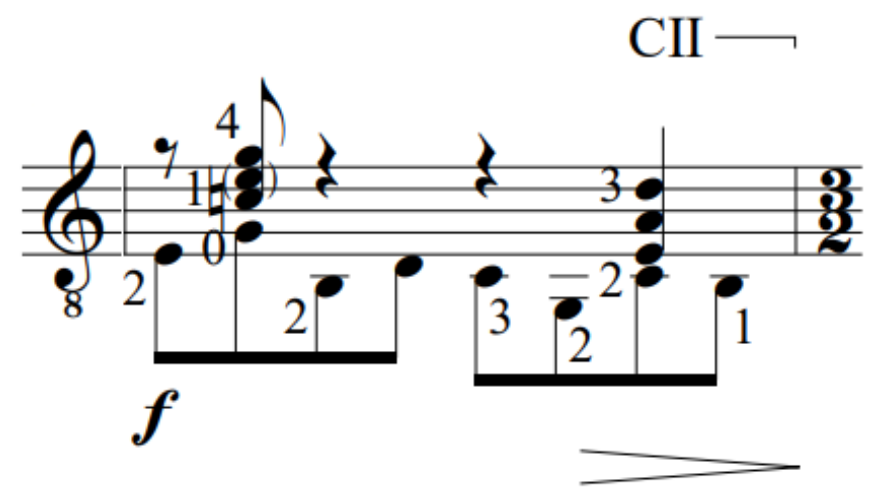

Figura 9: Ponteio, compasso 13.

Um acorde de Si menor é atingido no compasso 25. Nesta tônica de chegada, cabe dobrar a nota Fá\# em sua configuração, tornando-o um acorde de 6 notas mais sonoro e eficaz para a execução da passagem (figura 10).

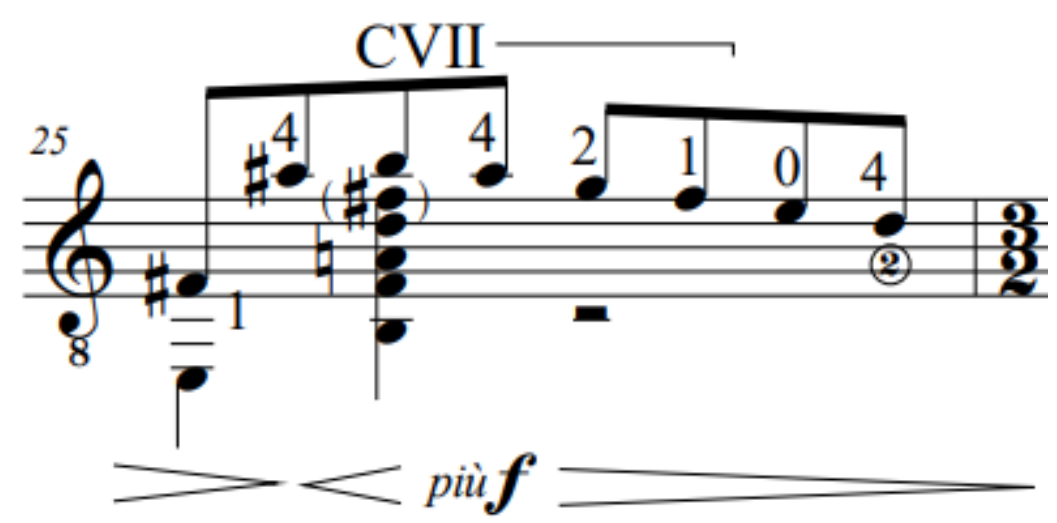

Figura 10: Ponteio, compasso 25. 
Mais uma vez, é válido acrescentar uma nota para tornar a estrutura harmônica ainda mais presente, além de contribuir para um dedilhado mais eficiente. Neste compasso em específico, fica opcionalmente dobrada a nota do 月, no acorde de Ré Maior com sétima do segundo tempo do compasso 27 (figura 11).

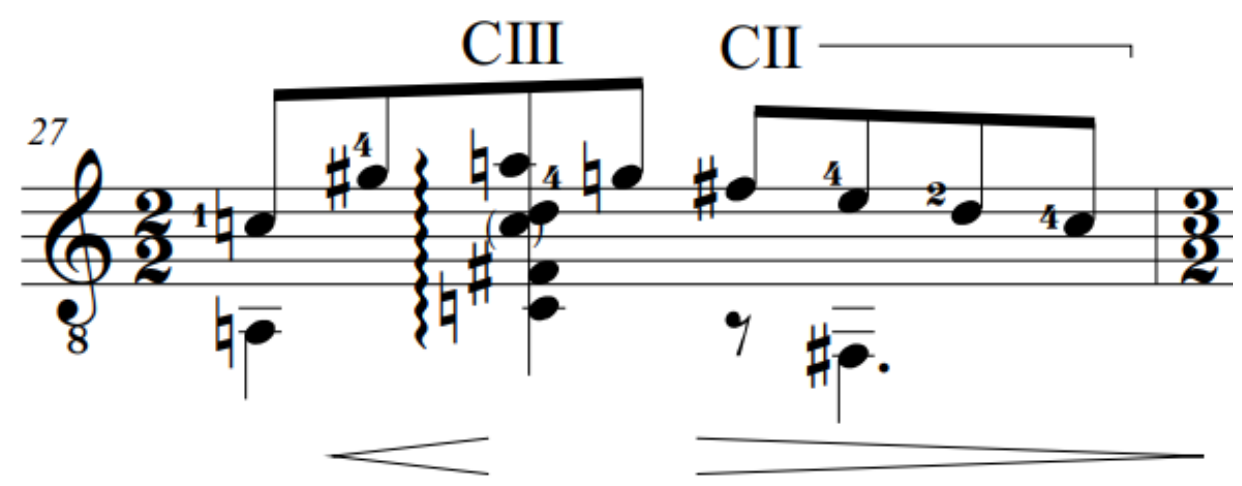

Figura 11: Ponteio, compasso 27.

A ideia da opção de digitação desta passagem, é gradualmente retornar a região das primeiras casas do instrumento, propiciando uma sonoridade mais brilhante para o prosseguimento da peça (figura 12).

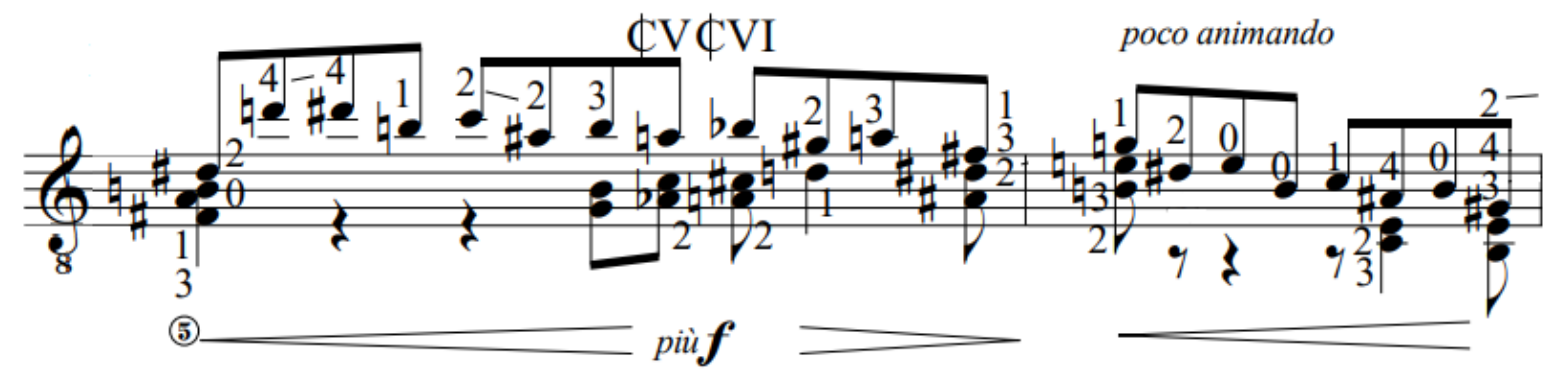

Figura 12: Passagem do compasso 30. 
Neste trecho, o dedilhado alternativo auxilia utilizando o dedo 3 como guia, em vez do dedo 4 como consta na partitura. Seria mais indicado para uma mão que necessita de mais espaço no braço do instrumento, por exemplo (figura 13).

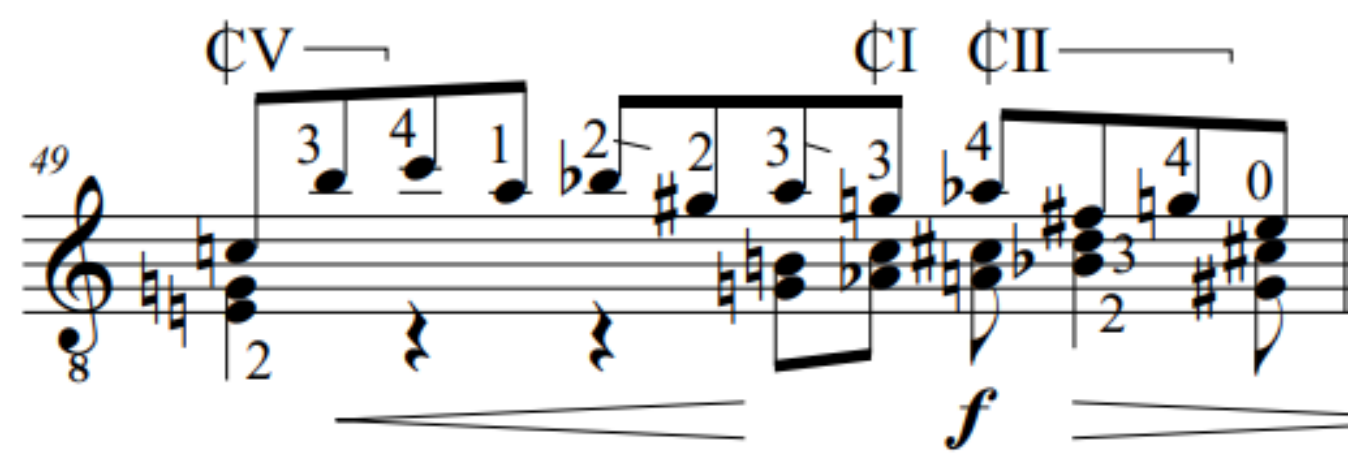

Figura 13: Dedilhado alternativo, Ponteio compasso 49.

VALSA (1961) - NOTAS INTERPRETATIVAS

à Maria Lívia São Marcos.

Expressivo, um pouco rubato, $m f$ - Forma: ABA e coda, 96 compassos.

A Valsa, apresenta longos e inesperados contornos melódicos com harmonias bastante sofisticadas (figura 14).

Peça de dificuldade acentuada para o intérprete, traz momentos de súbitos saltos e contraponto desafiador. Além é claro, da típica rigidez e detalhamento de nuances musicais (agógica e dinâmica) na escrita de Lacerda.

Já nos primeiros compassos, nota-se um movimento ascendente nos baixos que posteriormente se repetirá, com um novo desenho da melodia no registro agudo, quase como uma variação.

Na parte central, o compositor escreve um andamento ainda mais depressa que os $d=$ 112 iniciais, acrescentando mais um nível de dificuldade ao meticuloso material musical.

O fluxo rítmico só é quebrado ao final da peça, com acordes volumosos e mais espaçados, encaminhando a obra para seu austero desfecho.

Uma obra de primeiro valor, que certamente merece ser mais conhecida e tocada. 


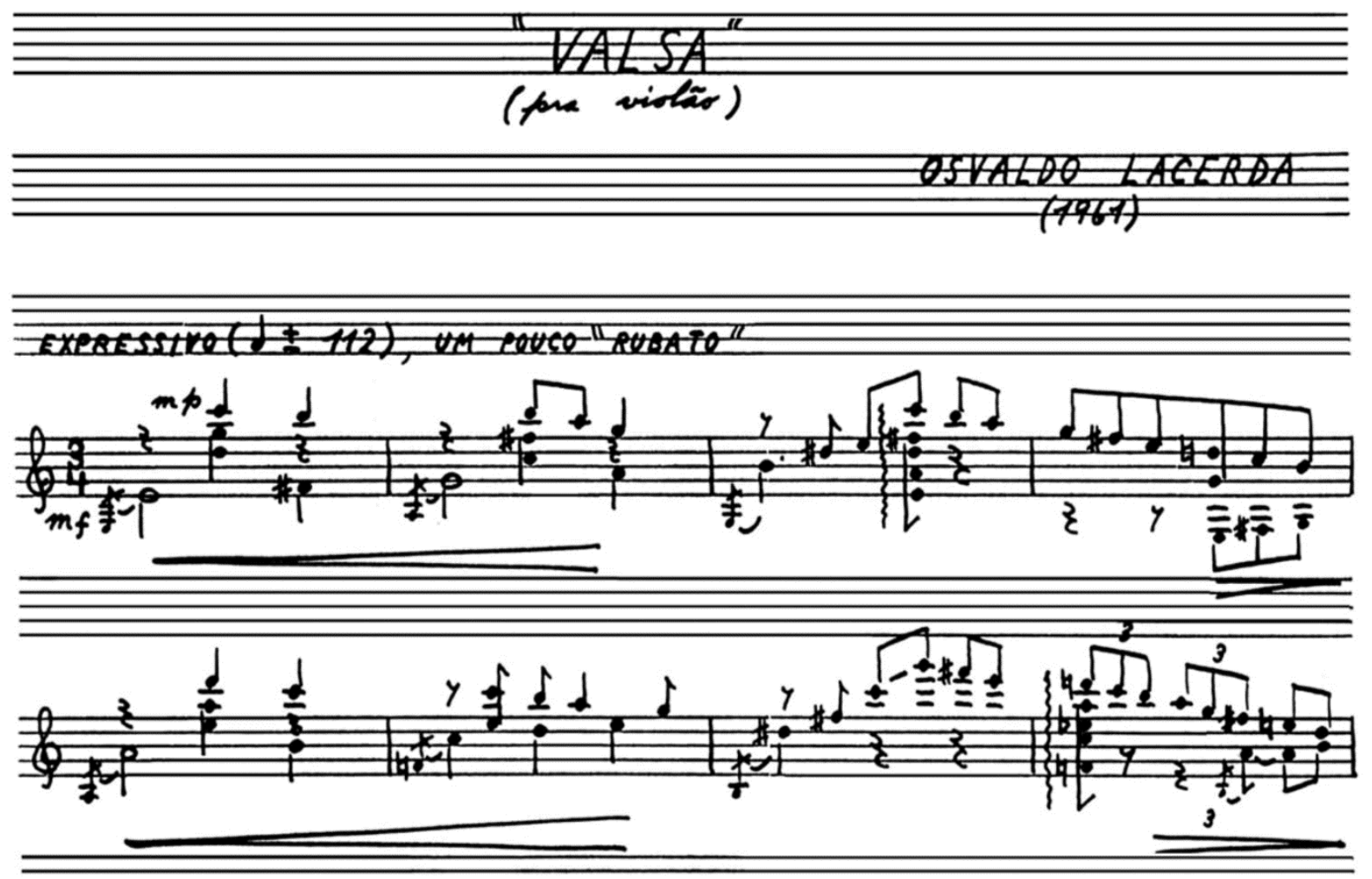

Figura 14: Compassos iniciais da Valsa para violão de Osvaldo Lacerda.

\section{VALSA (1961) - DEDILHADOS ALTERNATIVOS}

A Valsa trata-se de um desafio à parte. A obra mais difícil das peças solo de Lacerda. Com tortuosas linhas cromáticas e uma harmonia bastante expandida, traz trechos críticos para o intérprete. De qualquer maneira, é possível executar todo esse material musical rico e detalhado. Cabe atentar-nos a alguns trechos.

No primeiro tempo do compasso 31, no acorde composto pelas notas Fa, La, Si, Ré\#, é possível suprimir a nota $\mathrm{Si}$, segunda corda solta do violão. Fazendo com que o trecho renda mais e valorize o movimento da nota Mi (compasso anterior) chegando no Ré\#, favorecendo o contorno melódico da passagem (figura 15).

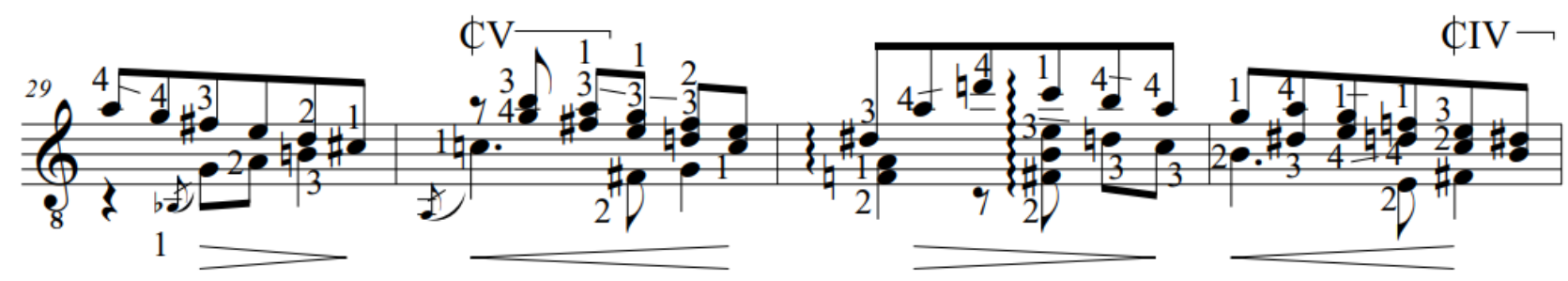

Figura 15: Compassos 29-32. 
No compasso 85 (coda), comparando-se com o compasso 39, parecem estar faltando os baixos escritos anteriormente (figura 16).
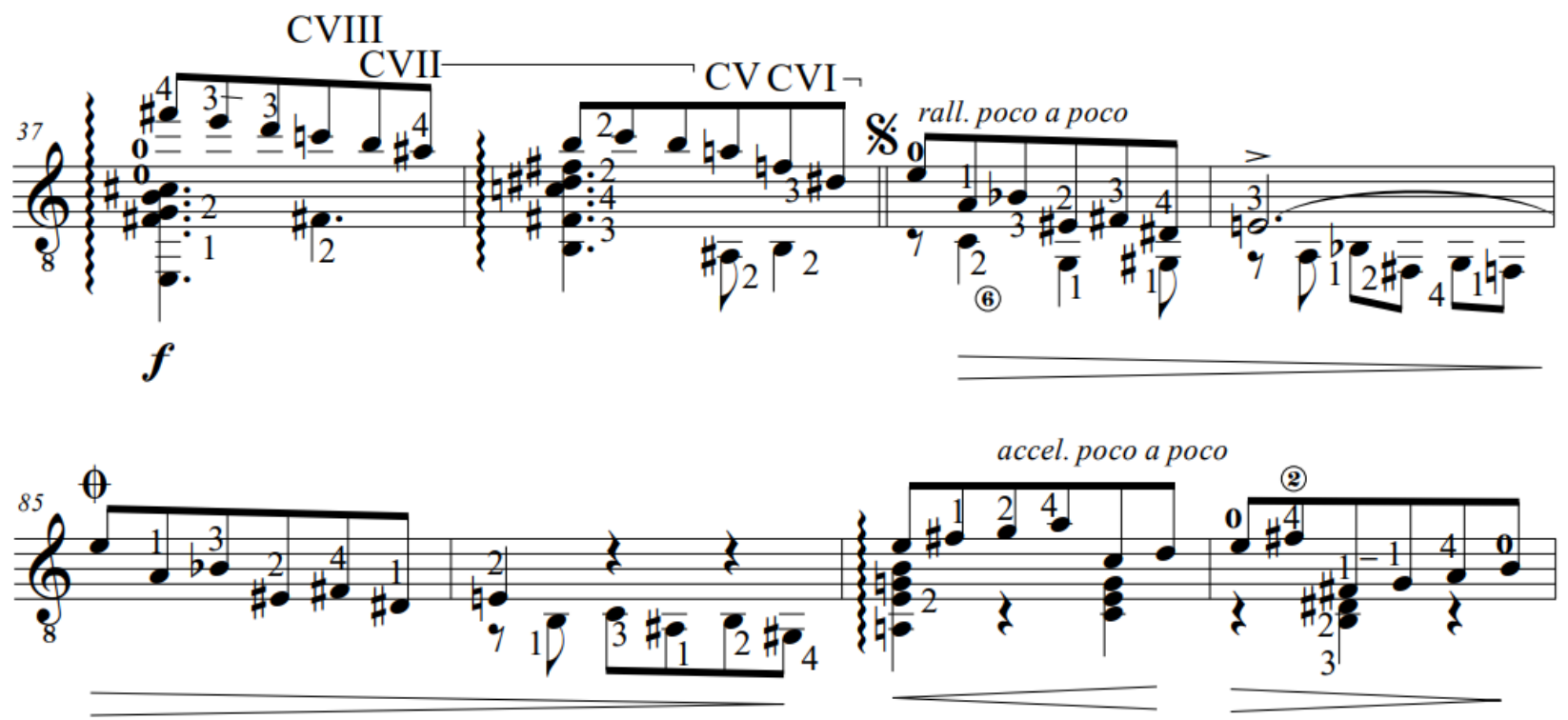

Figura 16: Compassos 37-40 e 85-86.

Neste momento do compasso 88 , é possível utilizar uma digitação que já adianta a sétima posição, chegando no acorde de Si Maior com mais facilidade (figura 17).

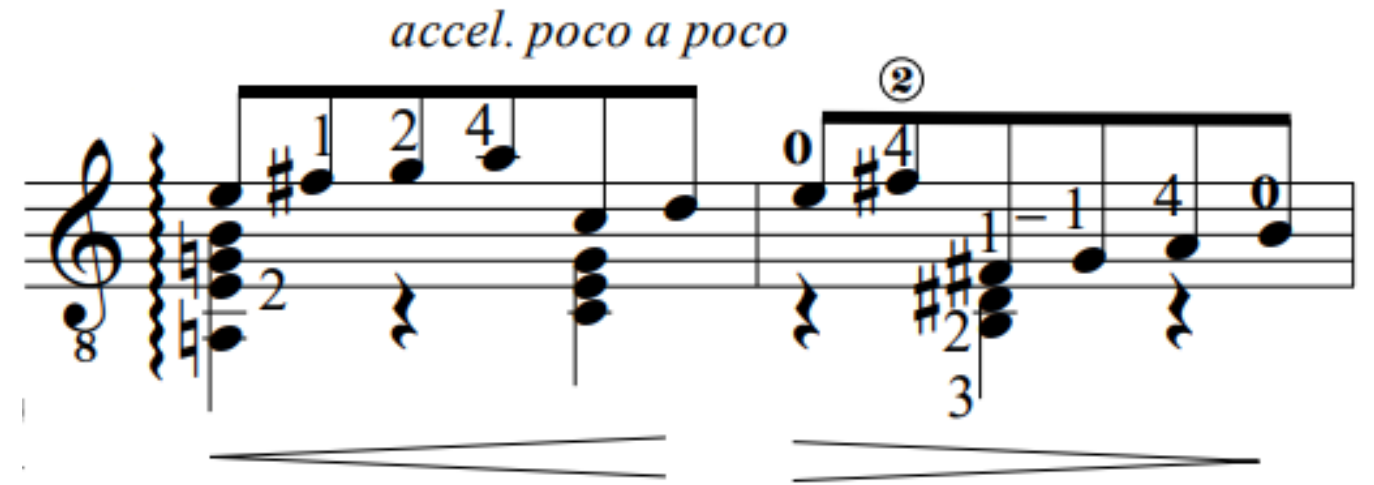

Figura 17: Valsa, compasso 88. 
Para manter um padrão coerente de ataque arpejado da harmonia, é possível acrescentar a nota Do ao acorde do compasso 94 (figura 18).

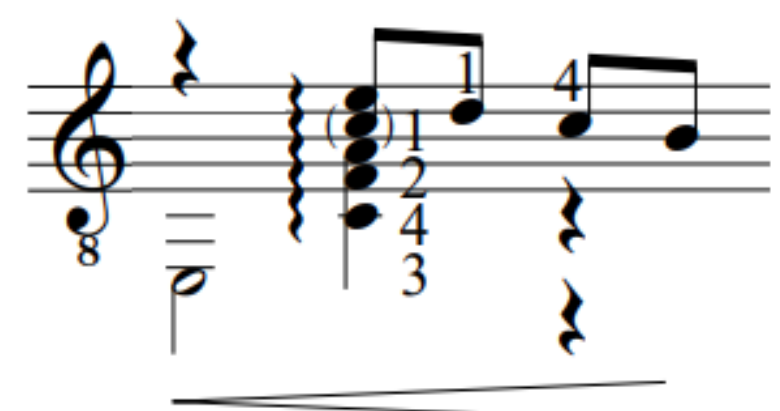

Figura 18: Valsa, compasso 94.

No penúltimo compasso duas possíveis digitações alternativas podem ser discutidas e escolhidas.

Na primeira, a valorização da melodia, tocando-se as duas notas finais do compasso ( $\mathrm{Si}$ Bemol e Sol) na quarta e segunda corda. Importante perceber que haverá uma variação de timbre em relação ao acorde final (figura 19).

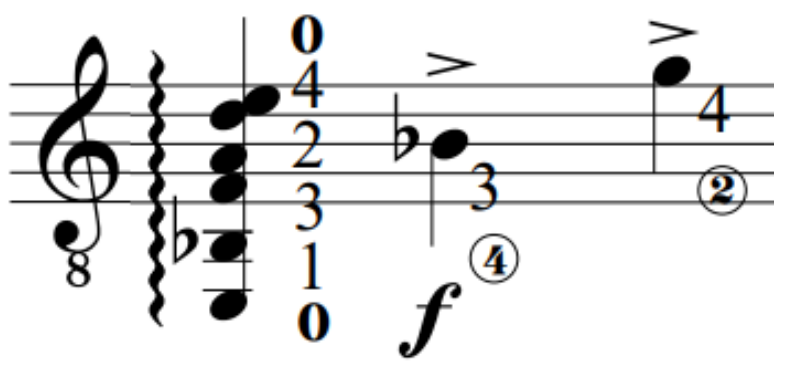

Figura 19: Valsa, compasso 95, primeira opção. 
Uma segunda opção, é realizar o dobramento das duas notas referidas anteriormente, tocando-as junto com seu respectivo par oitava abaixo (figura 20).

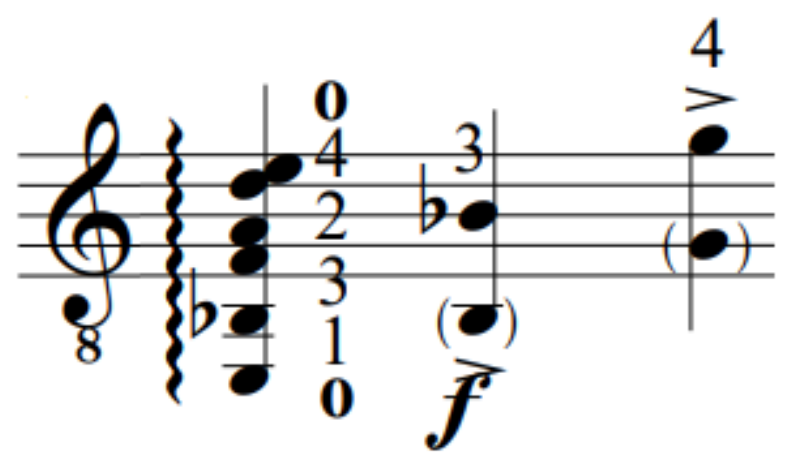

Figura 20: Valsa, compasso 95, segunda opção.

\section{MODA PAULISTA (1961) - NOTAS INTERPRETATIVAS}

à Manoel São Marcos.

Com animação, sempref - Canção popular. Forma de Rondó, 81 compassos.

A Moda Paulista é composta basicamente de um ponteado que utiliza a técnica do rasgueado ${ }^{3}$, entremeado por uma melodia acompanhada em terças paralelas ${ }^{4}$. Evidenciando a influência da sonoridade das violas caipiras brasileiras e inspiração no folclore popular ao modo de um desafio entre repentistas, incentivado, em grande medida, por Guarnieri.

Tanto na técnica instrumental, ponteado em terças e predominante em décimas, estas acusticamente mais favoráveis ao violão - como na forma (a primeira parte sempre retornando após os "romances" contados pelas terças, quase como um estribilho) a peça se enquadra na definição de Moda escrita por Mario de Andrade, onde ele aproxima a forma com a palavra cantada do Romance nordestino e da Modinha urbana.

Num paralelo com o alegre Ponteio n. 45 para piano de Guarnieri, e a Moda Paulista de Lacerda, é possível notar breves semelhanças na inspiração folclórica, manipulação dos temas e harmonia. Estreitando ainda mais a relação professor-aluno (figuras 21 e 22).

\footnotetext{
${ }^{3}$ Rasgueado também chamado de rasgueo é uma técnica violonística comumente associada ao violão flamenco espanhol. Também sendo usado no repertório do violão clássico. É executado usando os dedos da mão direita em padrões ritmicamente precisos e, frequentemente, rápidos. No caso da Moda Paulista, mais próximo aos gestos do violão popular e da viola caipira.
} 

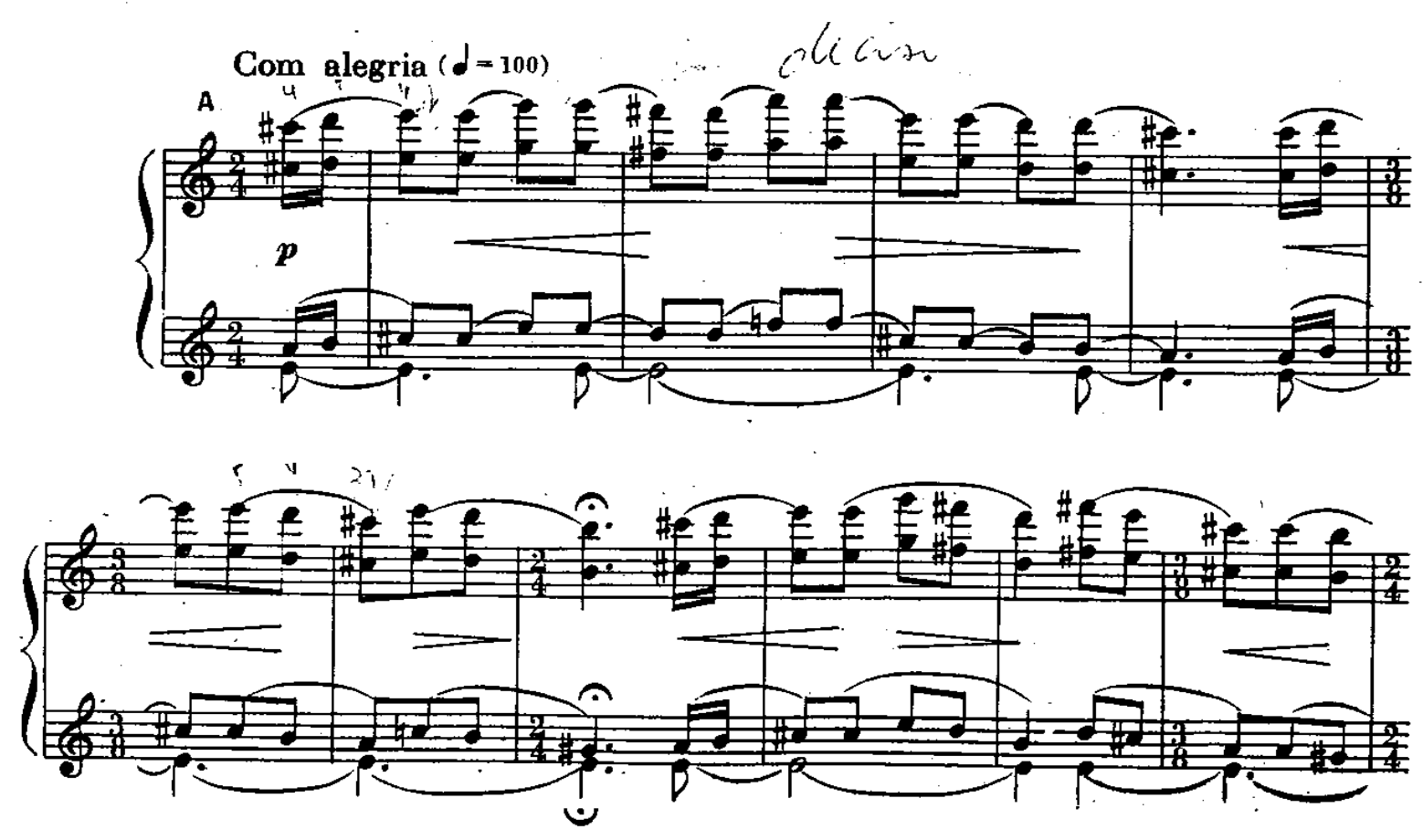

$$
\text { Br. } 3065
$$

Figura 21: Compassos iniciais do Ponteio n. 45 de Camargo Guarnieri.

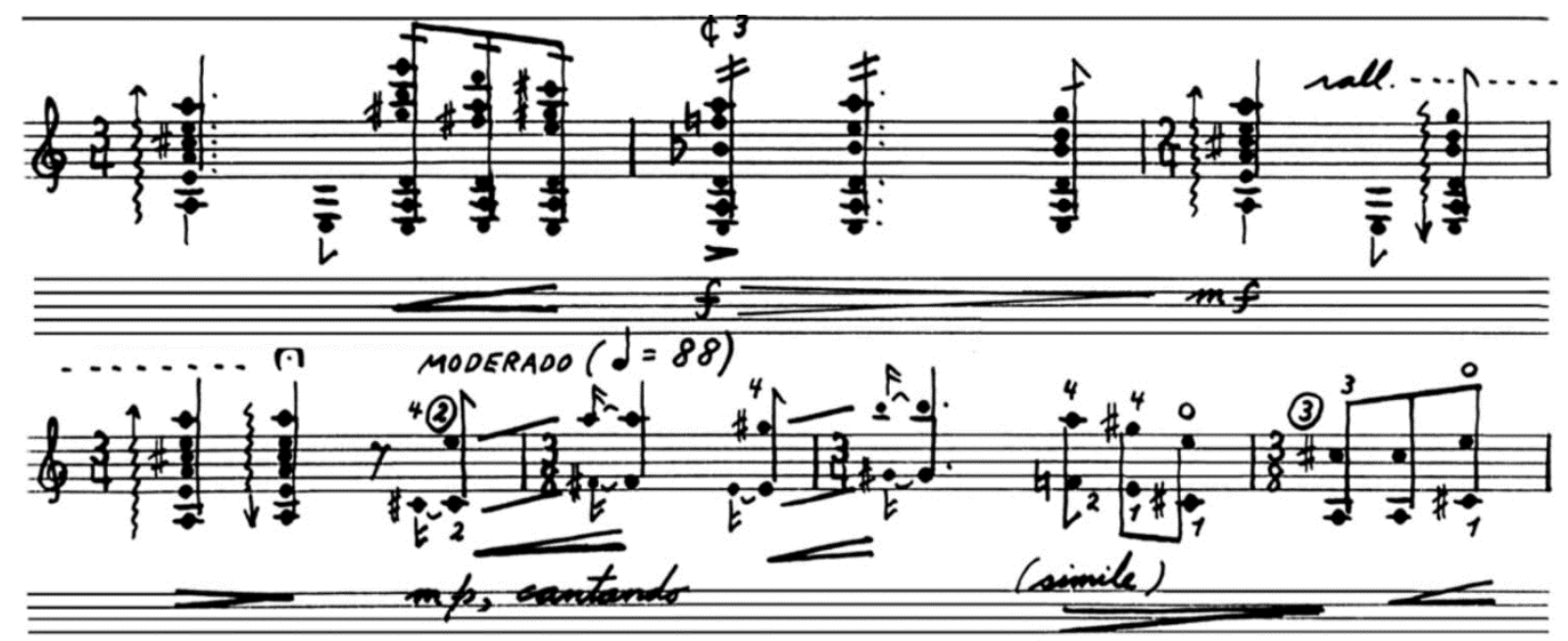

Figura 22: Final da parte rasgueada e início da melodia em décimas, da Moda Paulista de Lacerda. 
MODA PAULISTA (1961) - DEDILHADOS ALTERNATIVOS

A Moda Paulista é uma peça bastante idiomática e, de uma maneira geral, não necessita de nenhuma solução técnica mais rebuscada.

O trecho inicial da peça pode ser tocado inteiramente com pestanas e meias pestanas (figura 23).

Revisão, edição e digitação:

Lucas Vieira e Edelton Gloeden

Com animação $(\cdot=96)$
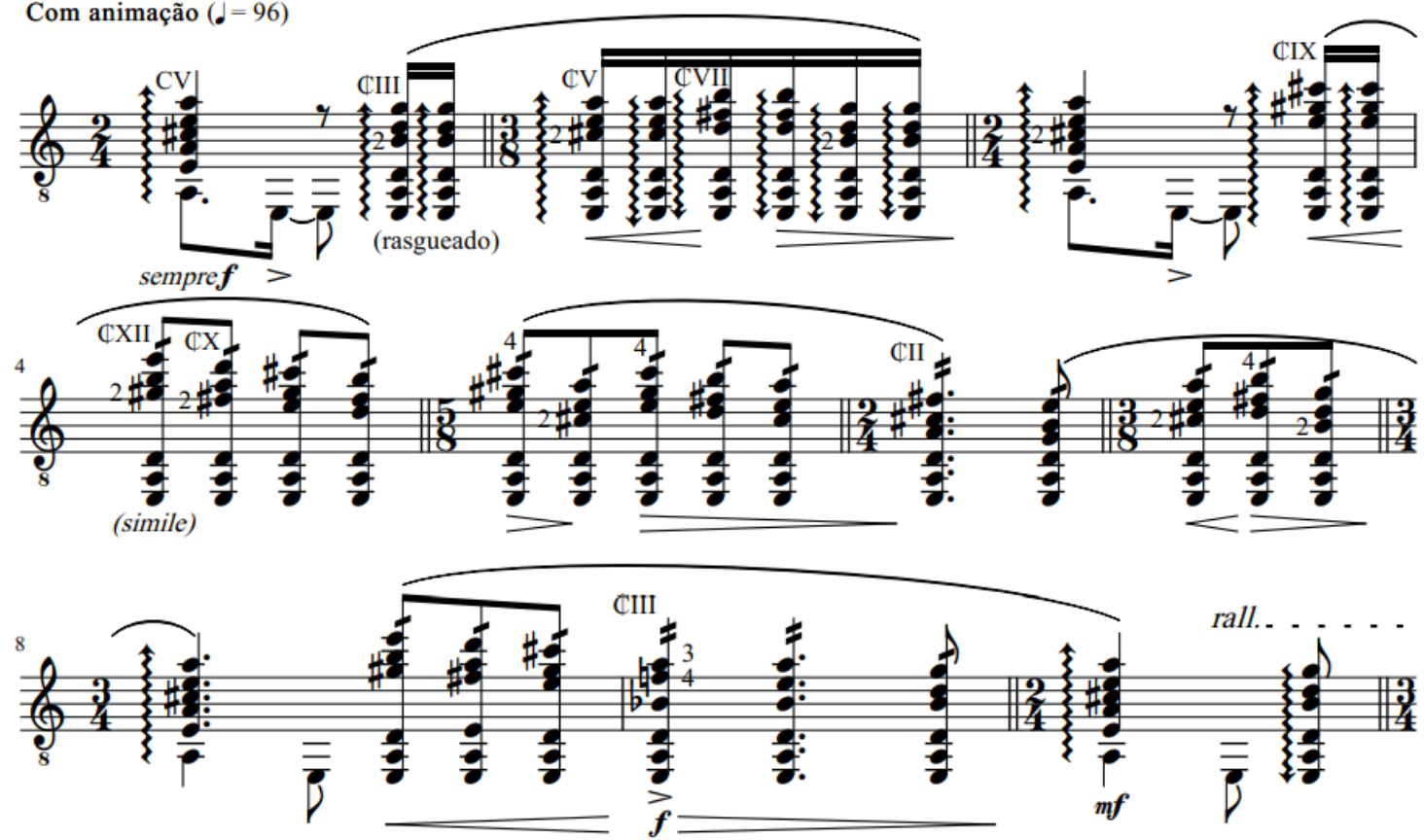

Figura 23: Compassos iniciais da Moda Paulista.

No compasso 48 é possível acrescentar a nota Lá ao acorde de Lá menor para um resultado mais robusto e um arpejo mais eficiente (figura 24).

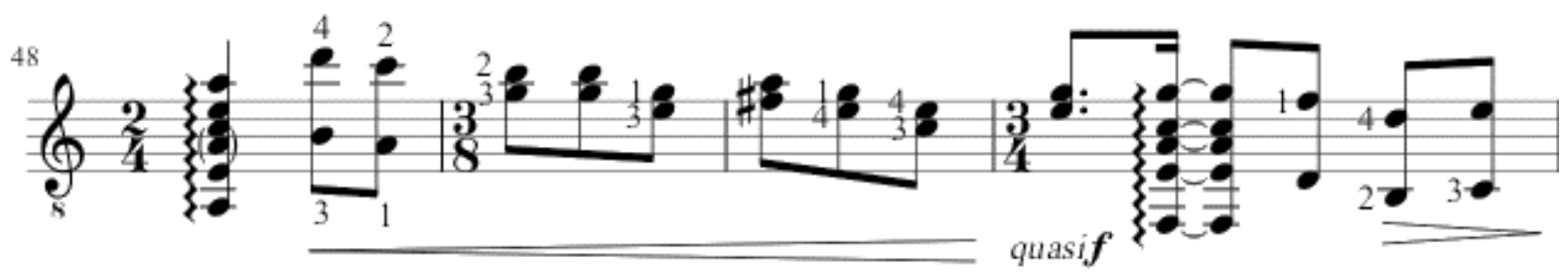

Figura 24: compassos 48-51. 
No último tempo do último compasso, há um harmônico artificial com a nota Mi, que pode ser encontrado na vigésima quarta posição. Houve um pequeno equívoco ao ser grafado na casa 25 (sic) (figura 25).

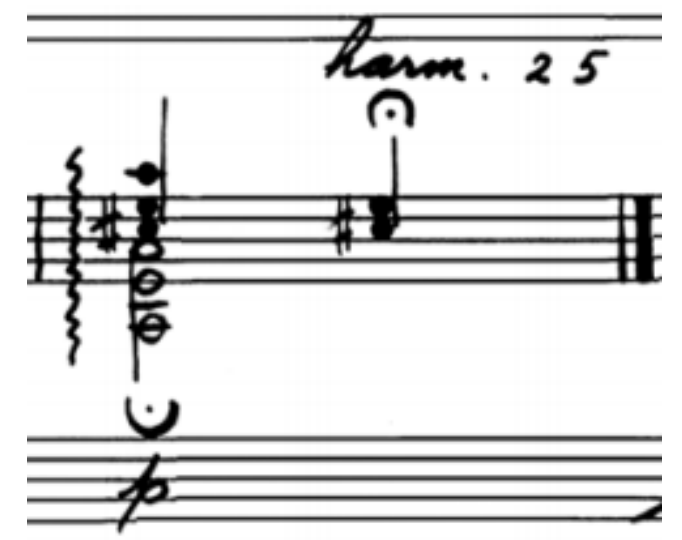

Figura 25: compasso final da Moda Paulista.

\section{5: CANÇÕES PARA VOZ E VIOLÃO}

A presença do canto na obra de Osvaldo Lacerda é notável. Sua música para canto coral e ciclos de canções para piano e voz são bastante conhecidas e executadas. O mesmo não pode ser dito sobre as peças para voz e violão. Apesar dessa formação contar com obras modelares no repertório brasileiro, com peças de compositores como Guarnieri, Guerra-Peixe e Marlos Nobre (apenas para citar alguns) as canções de Lacerda ainda permanecem sem nenhuma gravação e com difícil acesso as partituras, um objetivo que este trabalho procura beneficiar.

\section{AS DÁDIVAS (1968) - NOTAS INTERPRETATIVAS}

Moderado, $f$-Canção, 35 compassos.

Poema de Guilherme de Almeida (1890 - 1969).

A primeira canção do breve ciclo de peças para voz e violão, As Dádivas, é a mais singela e intimista. Apesar dela se manter num espectro dinâmico estreito, traz interessantes harmonias com inesperadas relações de mediante. $\mathrm{O}$ acompanhamento é difusivo e muito presente em todas as linhas cantadas pela voz. Linhas essas divididas em diferentes prolações e métricas, alternando entre compassos de dois e três tempos. Essas pequenas surpresas acabam por evitar uma certa obviedade no desenrolar da canção e mantêm a atenção do ouvinte até o final. 


\section{AS DÁDIVAS (1968) - APONTAMENTOS TÉCNICO-INTERPRETATIVOS}

Em termos técnicos, é uma peça acessível. Não há soluções técnicas extremas. Perfeitamente possível a um estudante que já tocou, por exemplo, um dos prelúdios de VillaLobos. No entanto, no penúltimo compasso há um acorde que, na maneira em que está escrito originalmente é impossível de ser sustentado. Uma possível solução, seria oitavar uma das notas do acorde, como no exemplo já digitado abaixo (figura 26).

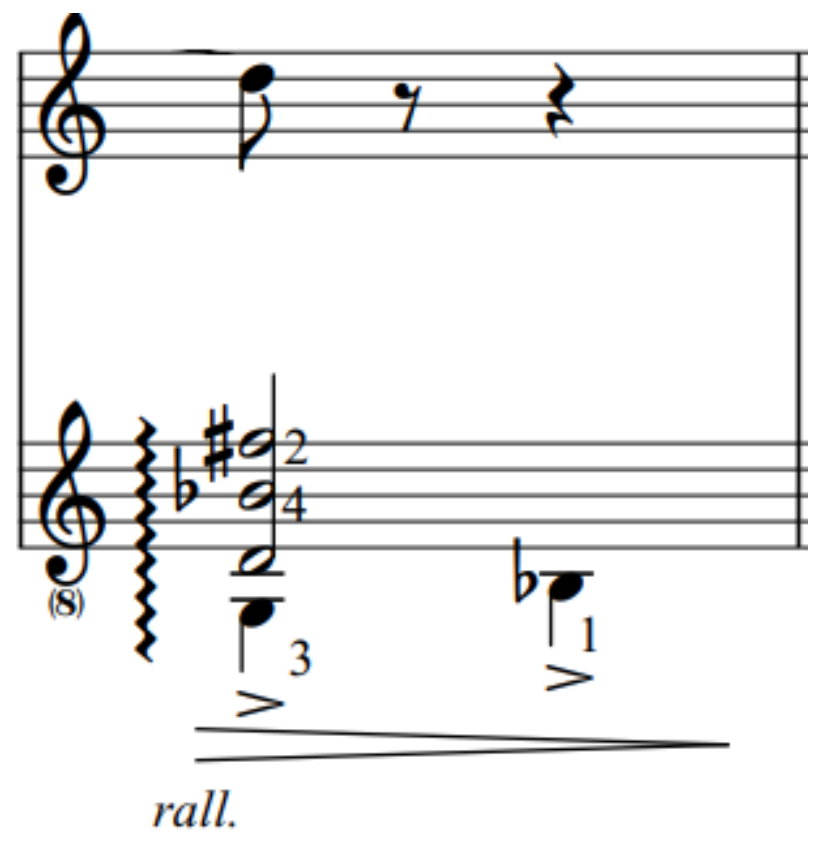

Figura 26: As Dádivas, compasso 34, possível solução.

\section{VÁCUO (1968)}

Moderado, mf, sempre marcato - Canção, 23 compassos.

Poema de Guilherme de Almeida (1890 - 1969).

A segunda canção do ciclo cria um ambiente consideravelmente mais árduo e seco. Característica prenunciada até mesmo no título. A linha vocal parece estar em segundo plano, com movimentos mais comedidos e reservados, em contraste às linhas contrapontísticas sóbrias e severas executadas pelo violão. Perfil também exposto no Ponteio, analisado anteriormente. Uma vez mais Lacerda faz uso das métricas irregulares, com um trecho bastante móvel na seção central da peça. 


\section{VÁCUO (1968) - DEDILHADOS ALTERNATIVOS}

Em relação à primeira canção, o salto de dificuldade e complexidade de execução em Vácuo é notável. É uma tarefa significativa manter firme o incessante fluxo rítmico, com as detalhadas nuances escritas pelo compositor.

No compasso inicial, existe uma possibilidade de digitação (figura 27).

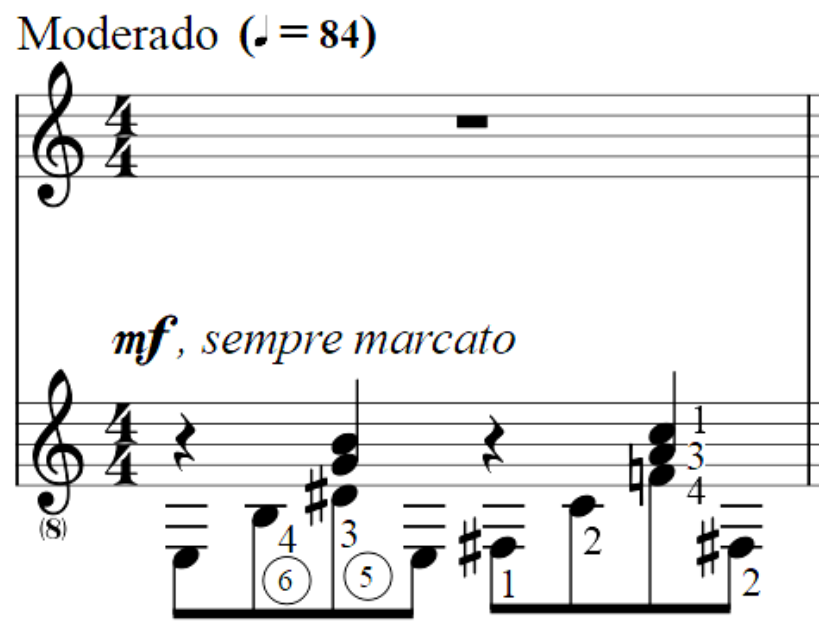

Figura 27: Vácuo, primeiro compasso.

Outro trecho passível de uma pequena solução técnica. No compasso 14, se for retirada a nota Si do acorde de Sol Maior, o resultado é mais natural, evitando uma desconfortável mudança de posição para um movimento que não está em evidência. Seria mais interessante destacar a linha do baixo que está se movendo (figura 28).

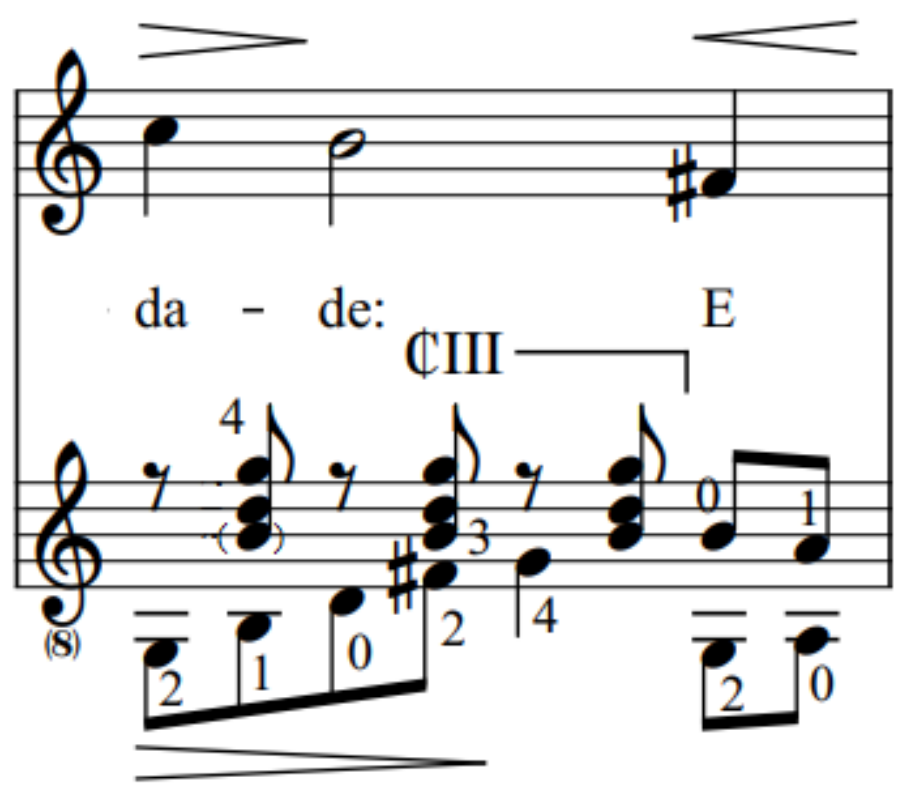

Figura 28: Vácuo, compasso 14. 


\section{SAUDADE (1968) - NOTAS INTERPRETATIVAS}

Animado, f- "no jeito de um cateretê", Canção estrófica, 82 compassos.

Texto de diversos autores.

Esta é certamente a canção que mais se aproxima da Moda Paulista, em termos de forma e estilo. Rasgueados que lembram figuras do acompanhamento do violão popular e uma melodia pueril que é equilibrada pela rica harmonia. Logo após a introdução, vem à tona um inesperado e animado ritmo de Catira $^{5}$ (figura 29). Do ponto de vista da performance, é uma peça bastante acessível, fazendo muito uso das cordas soltas e acordes abertos do instrumento.

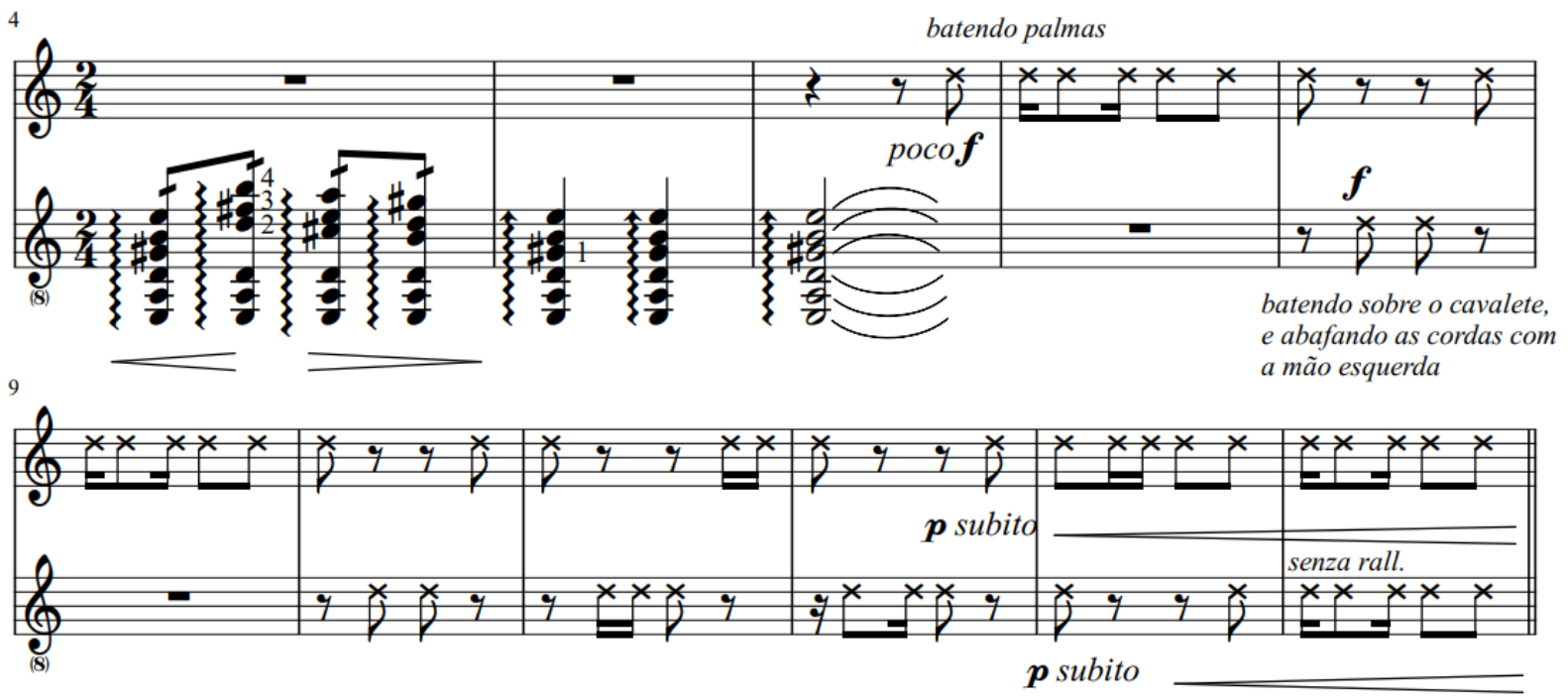

Figura 29: Ritmo de Catira.

\footnotetext{
${ }^{5}$ A Catira, é uma dança do folclore brasileiro, em que o ritmo musical é marcado pela batida dos pés e mãos dos dançarinos. De origem híbrida, com influências indígenas, africanas e europeias, a catira tem coreografia executada no Brasil, (boiadeiros e lavradores) e pode ser formada por seis a dez componentes e mais uma dupla de violeiros, que tocam e cantam a moda.
} 


\section{6: VERSÕES PARA FLAUTA E DOIS VIOLÕES (ORIGINAL PARA FLAUTA E PIANO)}

As versões inacabadas das peças para flauta e piano de Lacerda se mostraram, num primeiro momento, completamente impossíveis de serem executadas no andamento descrito nas partituras. Particularmente a Toccatina. Para acomodar toda a textura da escrita pianística no violão, veio a ideia do uso de dois violões para viabilizar a realização das versões aqui apresentadas. No processo de transcrição, foram necessários ajustes de tessitura, dobramentos, divisão de frases entre os violões e digitações engenhosas para manter integralmente o texto musical original. Alguns trechos da Toccatina e Cantilena, por exemplo, demandaram soluções criativas para a viabilização da execução nos andamentos propostos. Dado o rigor da escrita de Lacerda, as digitações e adaptações se dão em função das precisas dinâmicas e articulações levando em conta as regiões das cordas que soam bem no instrumento.

Antes de percorrermos os aspectos e detalhes das transcrições, segue um breve exemplo do início da versão do compositor da Toccatina, reiterando a impossibilidade de execução de alguns trechos. As partituras inacabadas estarão anexadas ao fim deste trabalho. (figura 30).
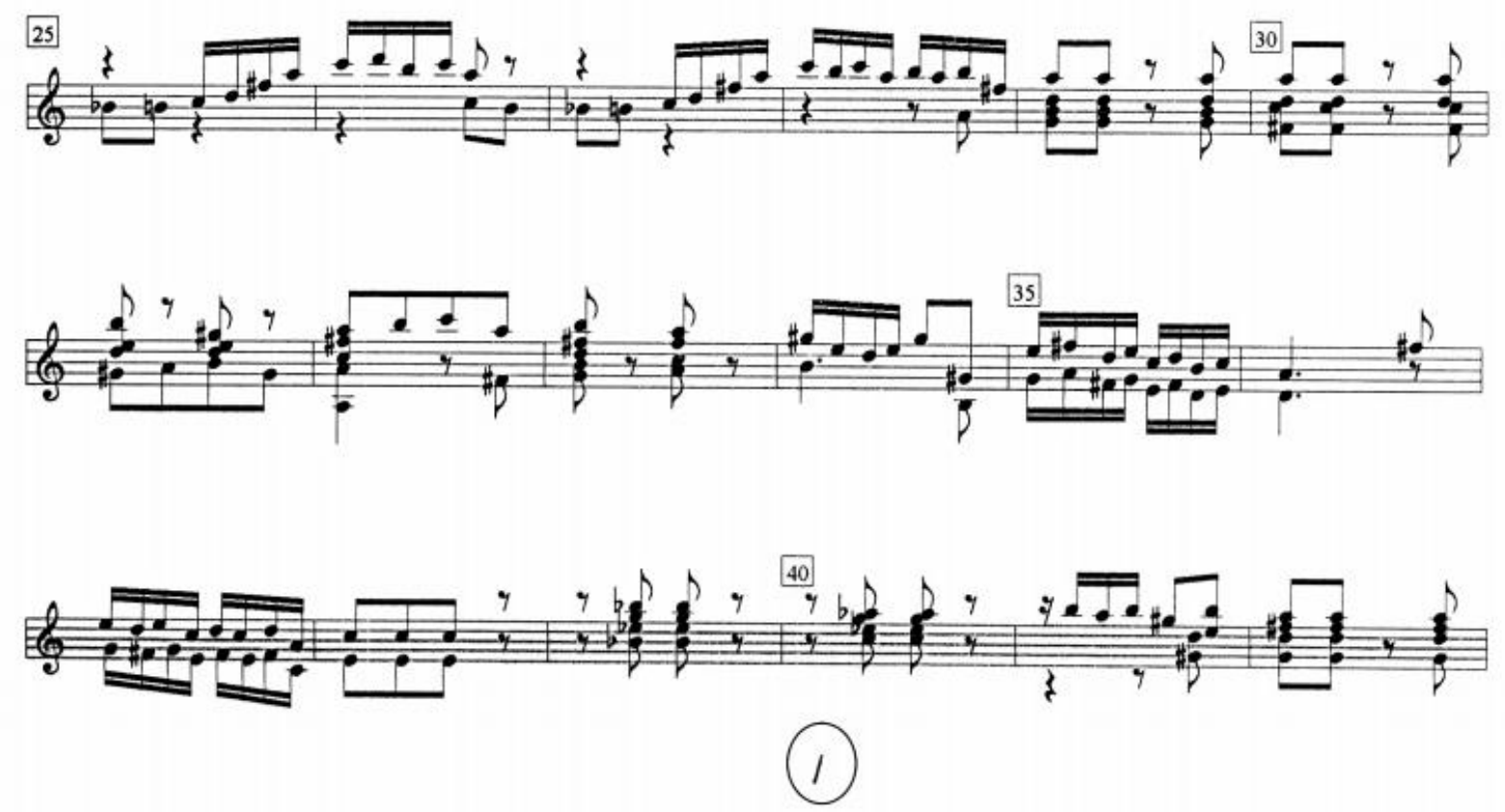

Figura 30: Compassos finais da primeira página da Toccatina, com exemplos de passagens iniváveis no andamento de $d=132$. 
CANTILENA (1974) - ao Antonio Carlos Carrasqueira

Andante non troppo lento, ma sostenuto, poco f, "sempre com desenvoltura"

Forma: ABA' e coda, 61 compassos.

Na Cantilena, somos apresentados de início à uma longa e sincopada melodia, num calmo andamento. $\mathrm{O}$ acompanhamento, em contraste, se mostra muito mais articulado e até mesmo staccato em alguns momentos. Original e transcrição (figura 31 e 32).
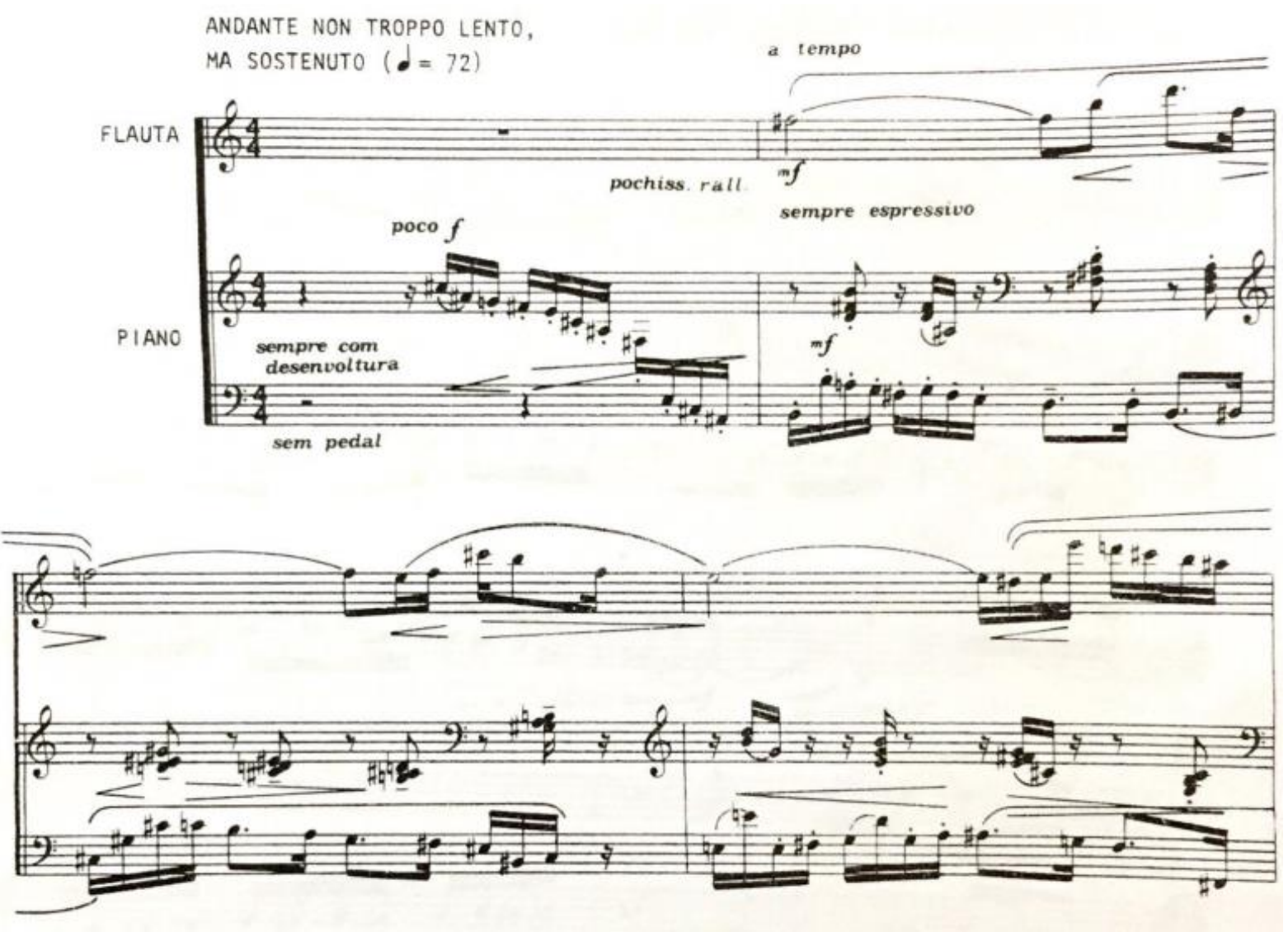

Figura 31: Cantilena (original), compassos iniciais. 

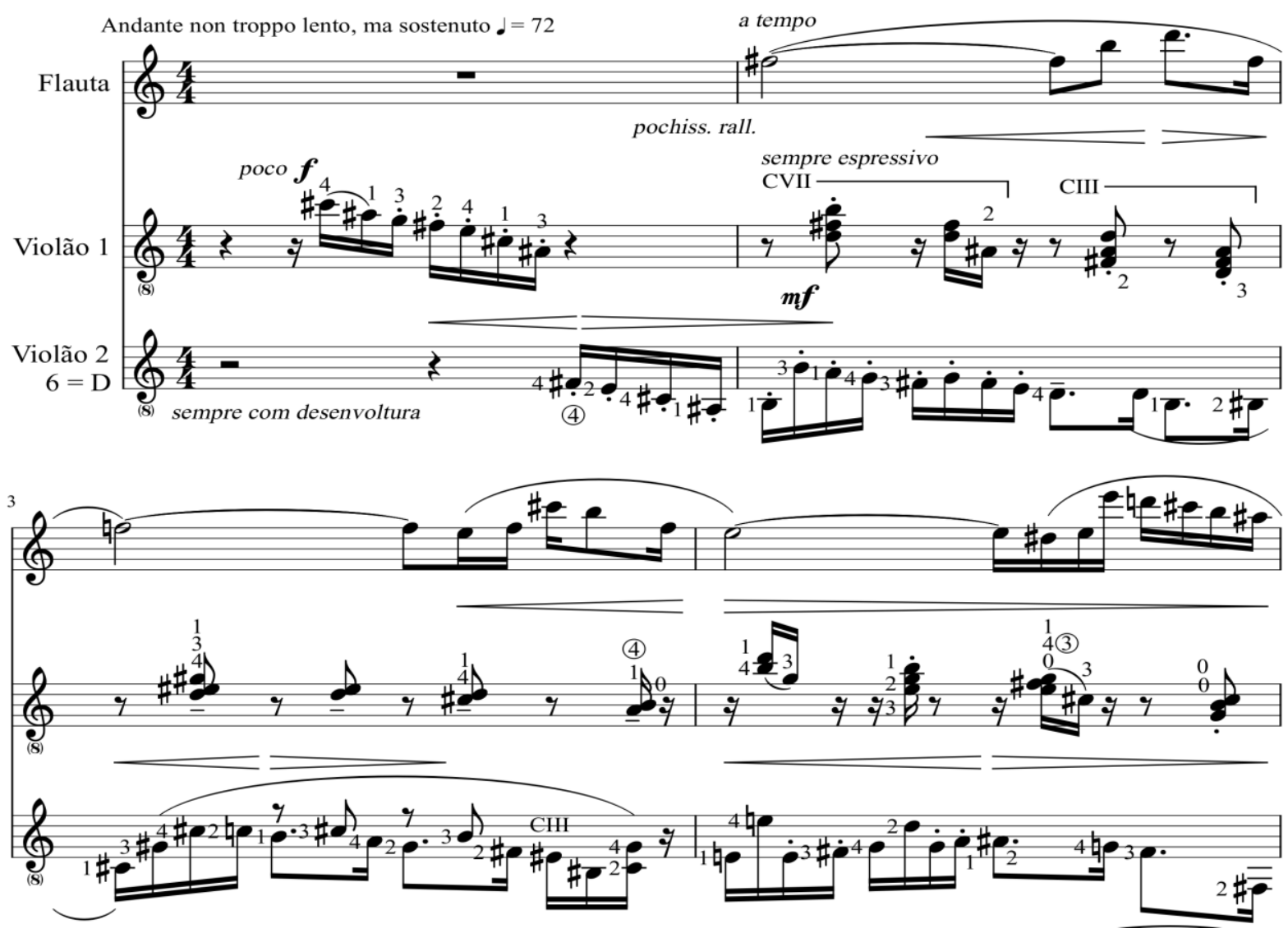

Figura 32: Cantilena (transcrição), compassos iniciais. 
Na parte B, há uma inesperada modulação para Si Bemol Maior, bastante distante da tonalidade inicial de Si menor. Porém essa transição vem de maneira suave e preparada com os cromatismos da seção anterior. Original e transcrição (figura 33 e 34).
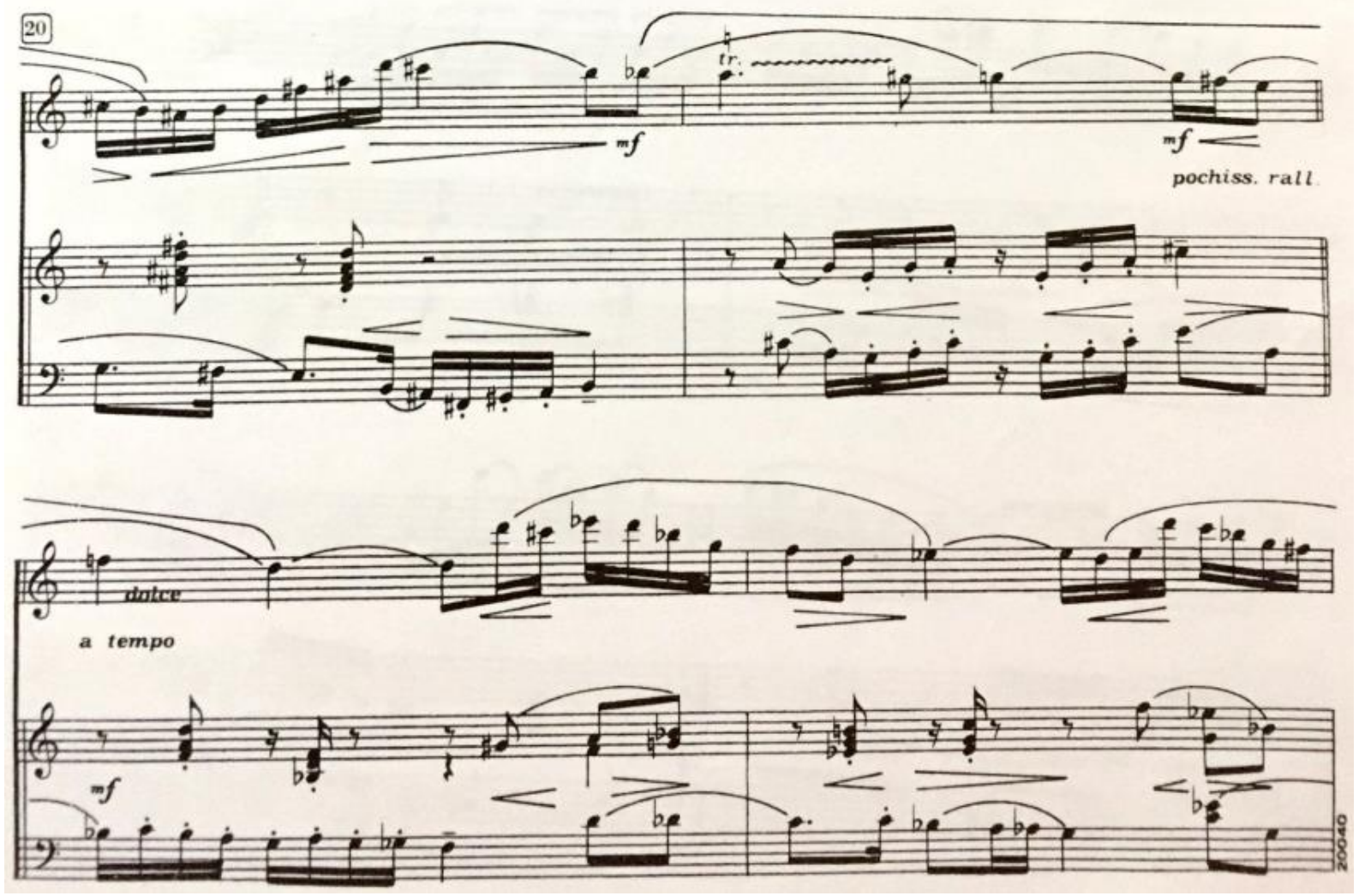

Figura 33: Cantilena (original), seção em Si Bemol Maior, compasso 22. 

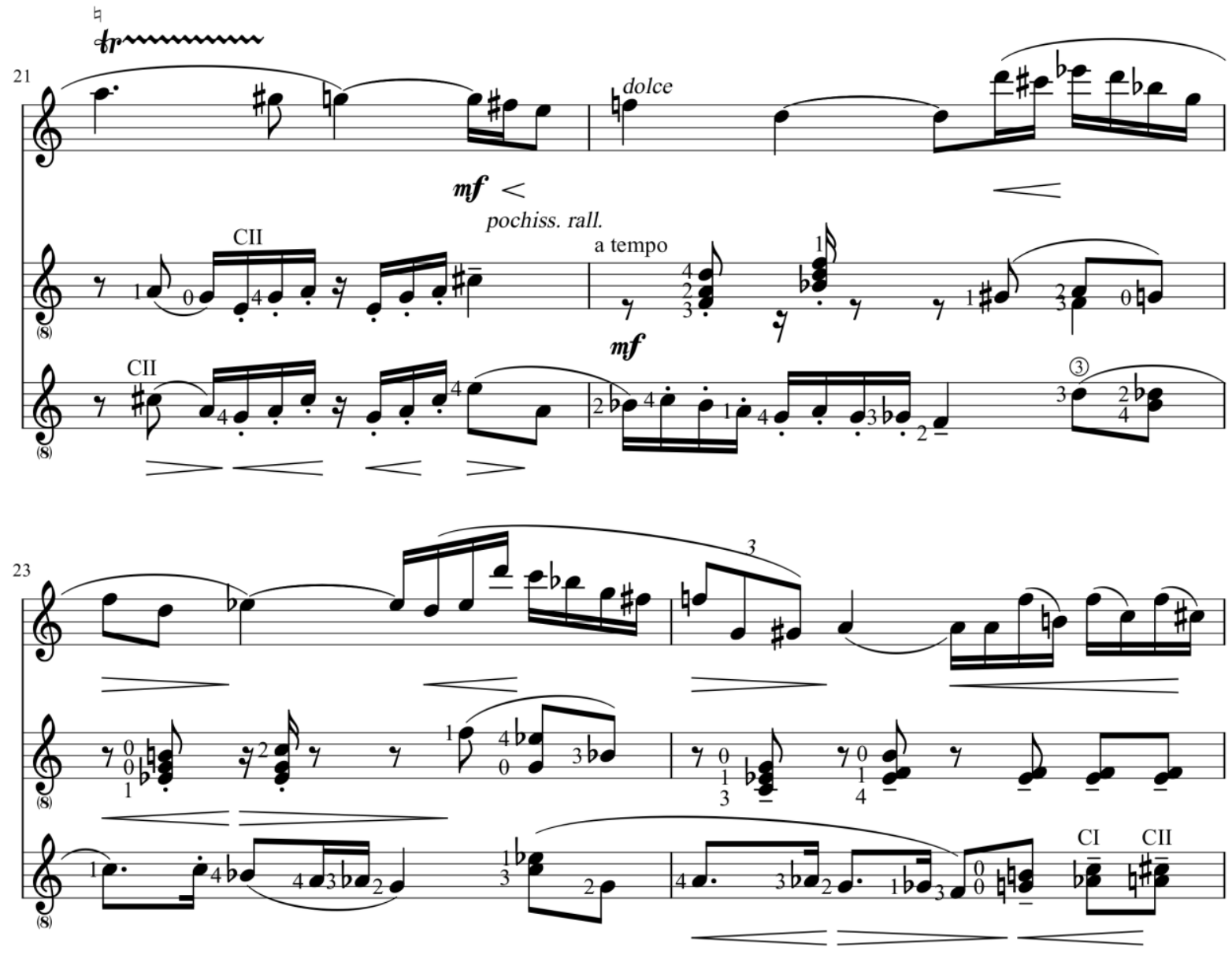

Figura 34: Cantilena (transcrição), seção em Si Bemol Maior, compasso 22. 
No retorno da primeira parte, compasso 41, os violões apresentam o tema inicialmente tocado pela flauta (figura 35) e a peça começa a se encaminhar para a coda e parte final.
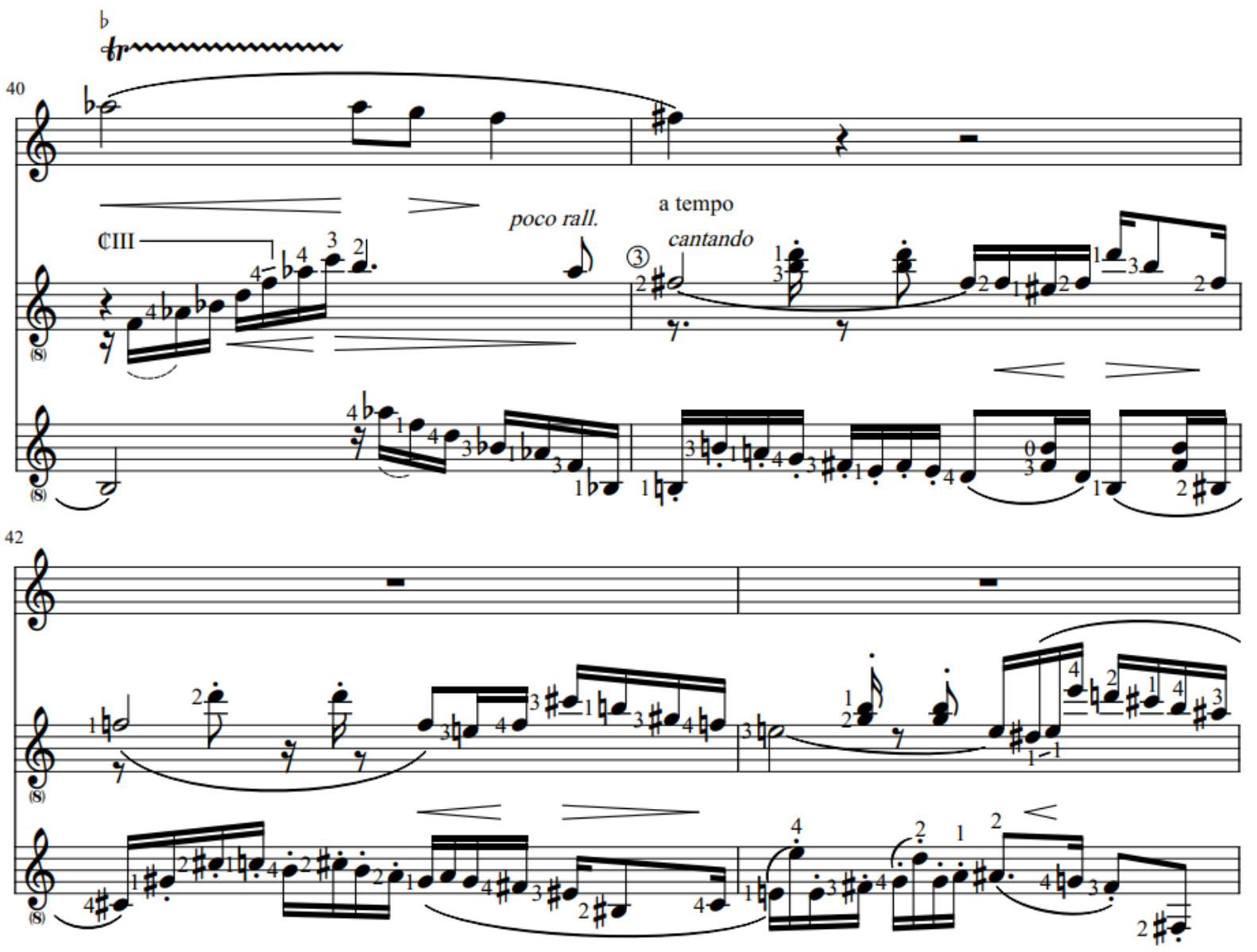

Figura 35: Cantilena, início da exposição do tema nos violões no compasso 41. 
POEMETO (1974)

Tranquilamente movido, $m f$ - Forma de prelúdio, 66 compassos.

O Poemeto funciona perfeitamente como um breve prelúdio para iniciar um concerto. Uma melodia airosa e singela é tocada pela flauta, enquanto os violões completam a harmonia com arpejos e pequenos comentários contrapontísticos (figura 36). A ineressante afinação em Db do segundo violão, proporciona uma nota grave pouco comum, completando a textura pianística em alguns trechos.

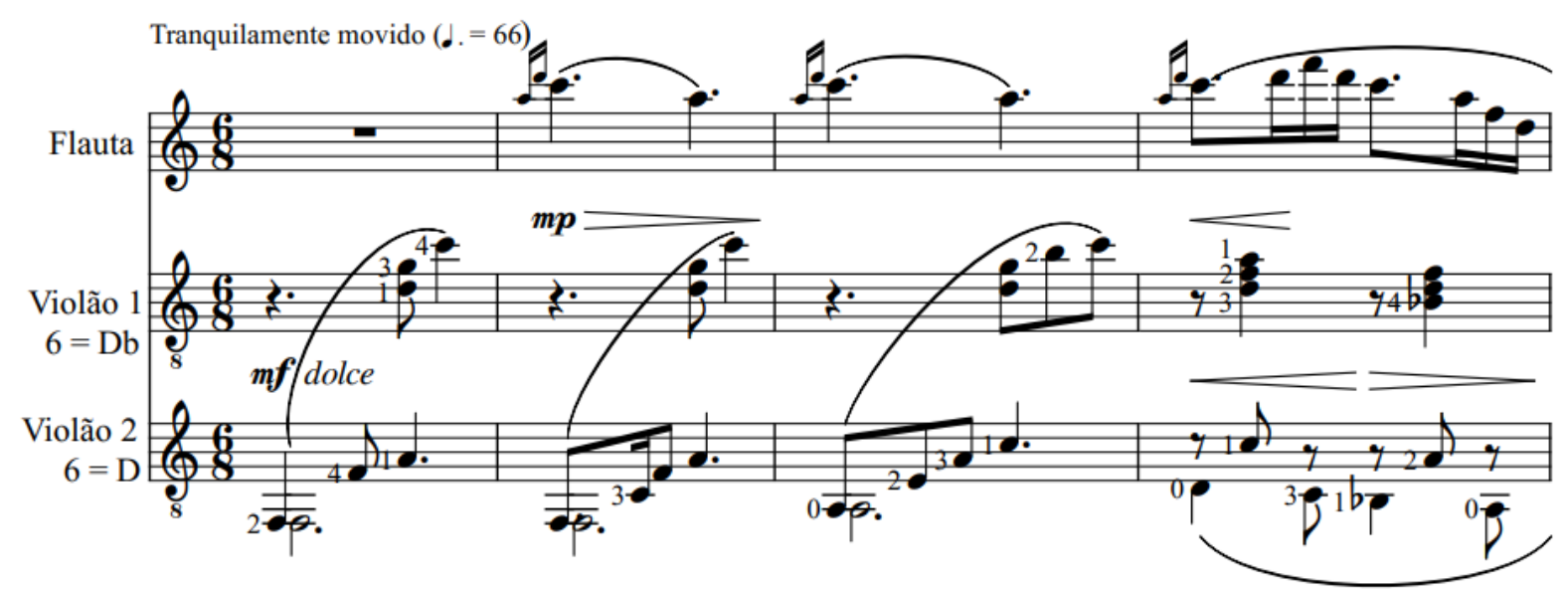

Figura 36: Poemeto, tema inicial.

São apresentados dois temas antes de um momento tenso e cromático na metade da peça, para logo em seguida o tema principal voltar, agora no violão (figura 37), e ser arrematado pela flauta ao se encaminhar para os compassos finais.

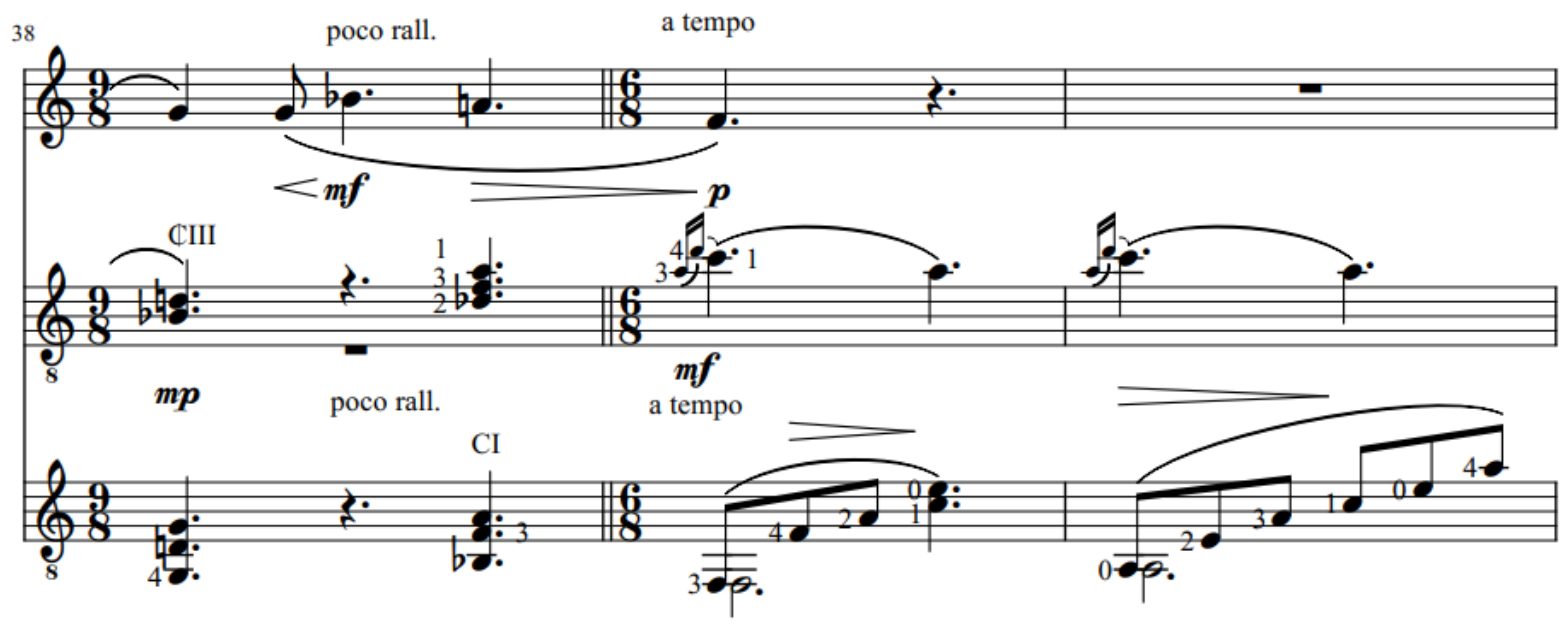

Figura 37: Poemeto, reexposição nos violões. 
TOCCATINA (1974)

Vivo, poco f-Forma ABA' e coda, 139 compassos.

A forma Toccatina é referida no repertório quando temos peças desafiadoras, de alta dificulde técnica e que demandam destreza do intérprete. Esse é o caso da Toccatina (1974) de Lacerda. Ela é a obra mais desafiadora do ciclo de peças para flauta e dois violões. Um andamento acelerado, articulações rigorosas, diálogos precisos e escalas ligeiras são elementos que os intérpretes irão se deparar no processo de leitura, estudo e ensaio (figura 38).
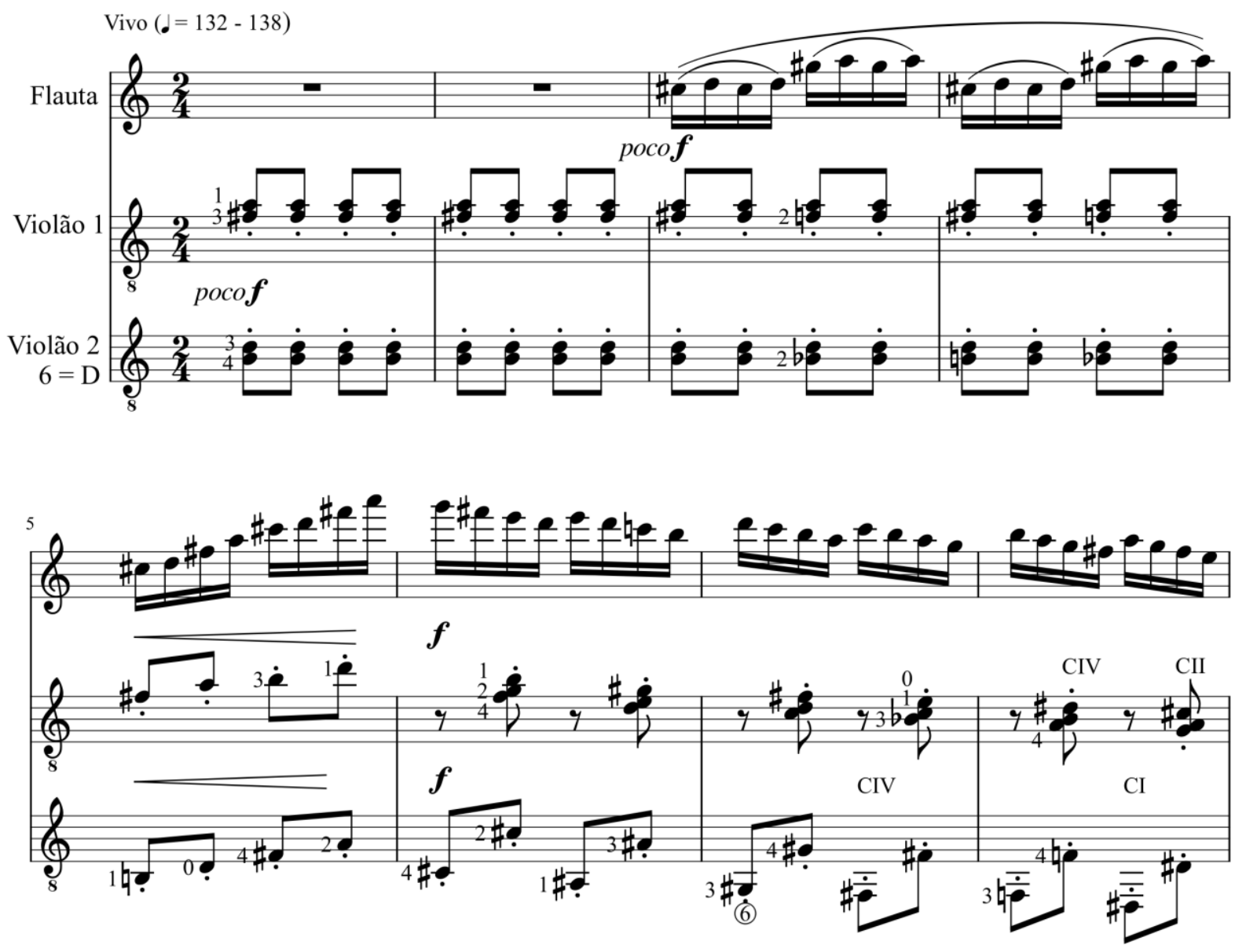

Figura 38: Toccatina, compassos iniciais. 
Formalmente, o sufixo "ina" no termo "Toccata", indica a ausência ou pequeno desenvolvimento na segunda parte. Que é o caso na obra. O desenvolvimento se inicia com uma nova harmonia (figura 39), com a mesma prolação inicial e ao seu fim o tema inicial é reexposto dessa vez no violão. Uma peça entusiasmante, com sabor e caráter nacionais que poderá ganhar espaço no repertório de concerto dos violonistas e flautistas.

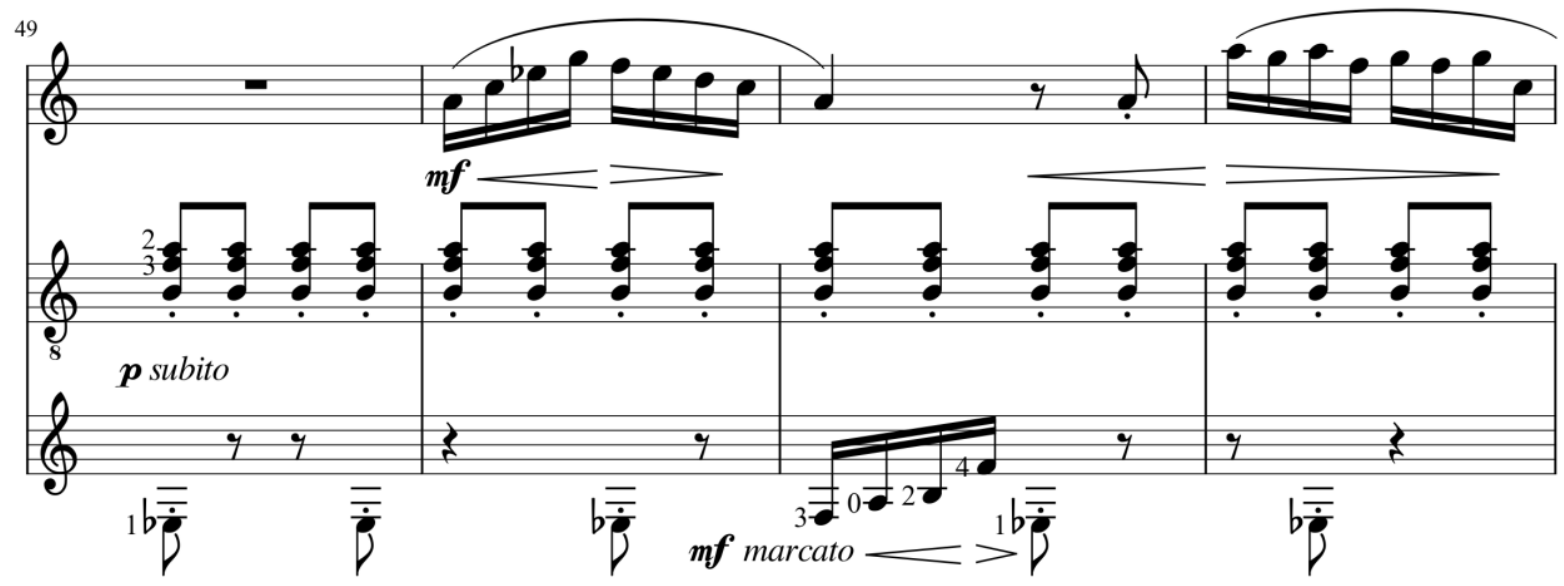

Figura 39: Toccatina, início do breve desenvolvimento. 


\section{CAPÍTULO 4}

\section{PARTITURAS REVISADAS, EDITADAS E DIGITADAS}

A seguir, as edições revisadas das partituras manuscritas das obras para violão de Osvaldo Lacerda. As sugestões dos revisores aparecem discretamente na forma de um asterisco. (A numeração das páginas do trabalho seguirá normalmente após as partituras). 


\section{VIOLÃO SOLO}




\section{abenseme \\ PONTEIO \\ para violão}

Revisão, edição e digitação:

Osvaldo Lacerda

Lucas Vieira e Edelton Gloeden

Sem pressa $(d \pm 50, \downarrow \pm 100)$
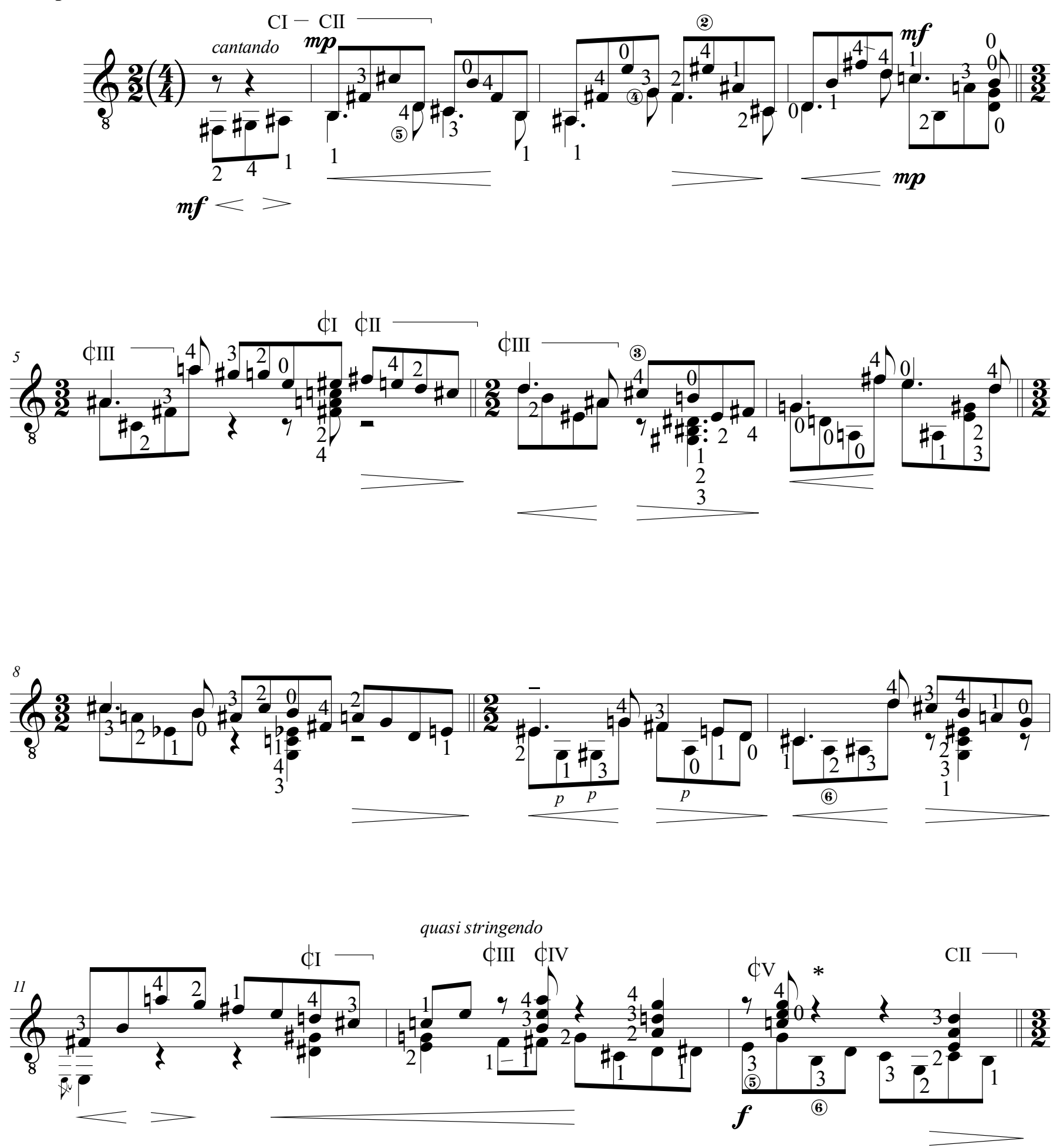


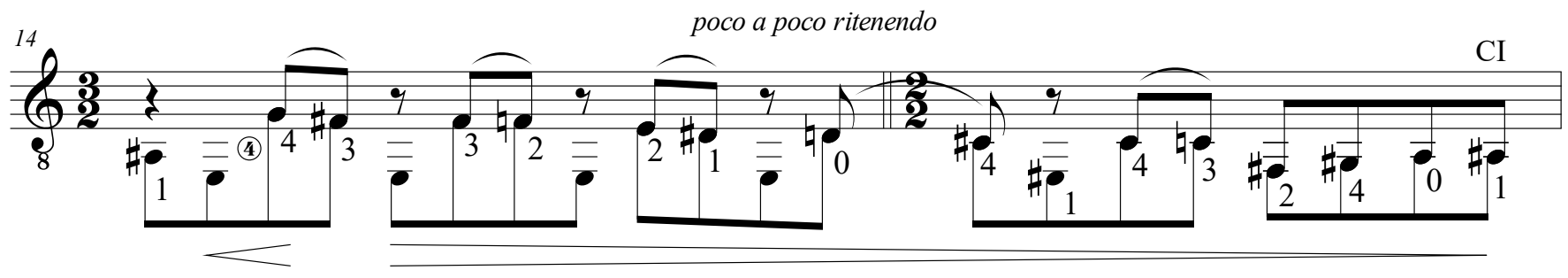

a tempo

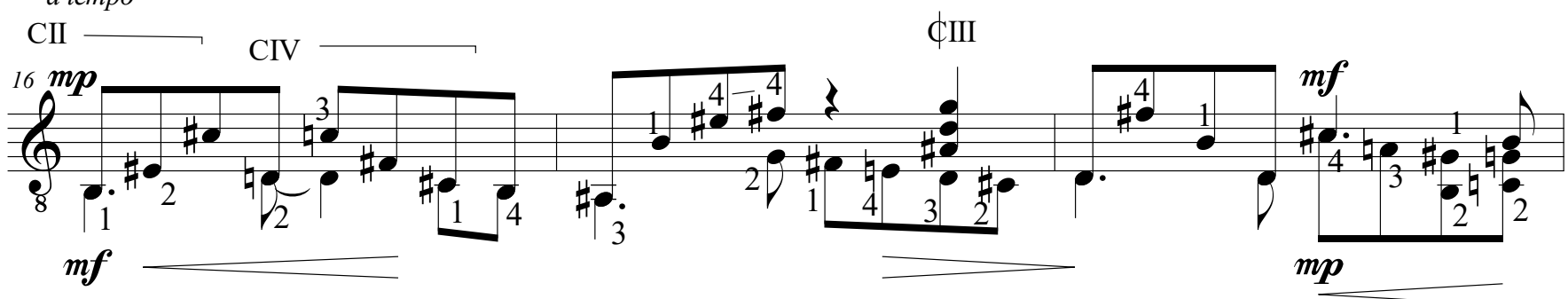

CIII $\longrightarrow \quad$ CIV ᄀ
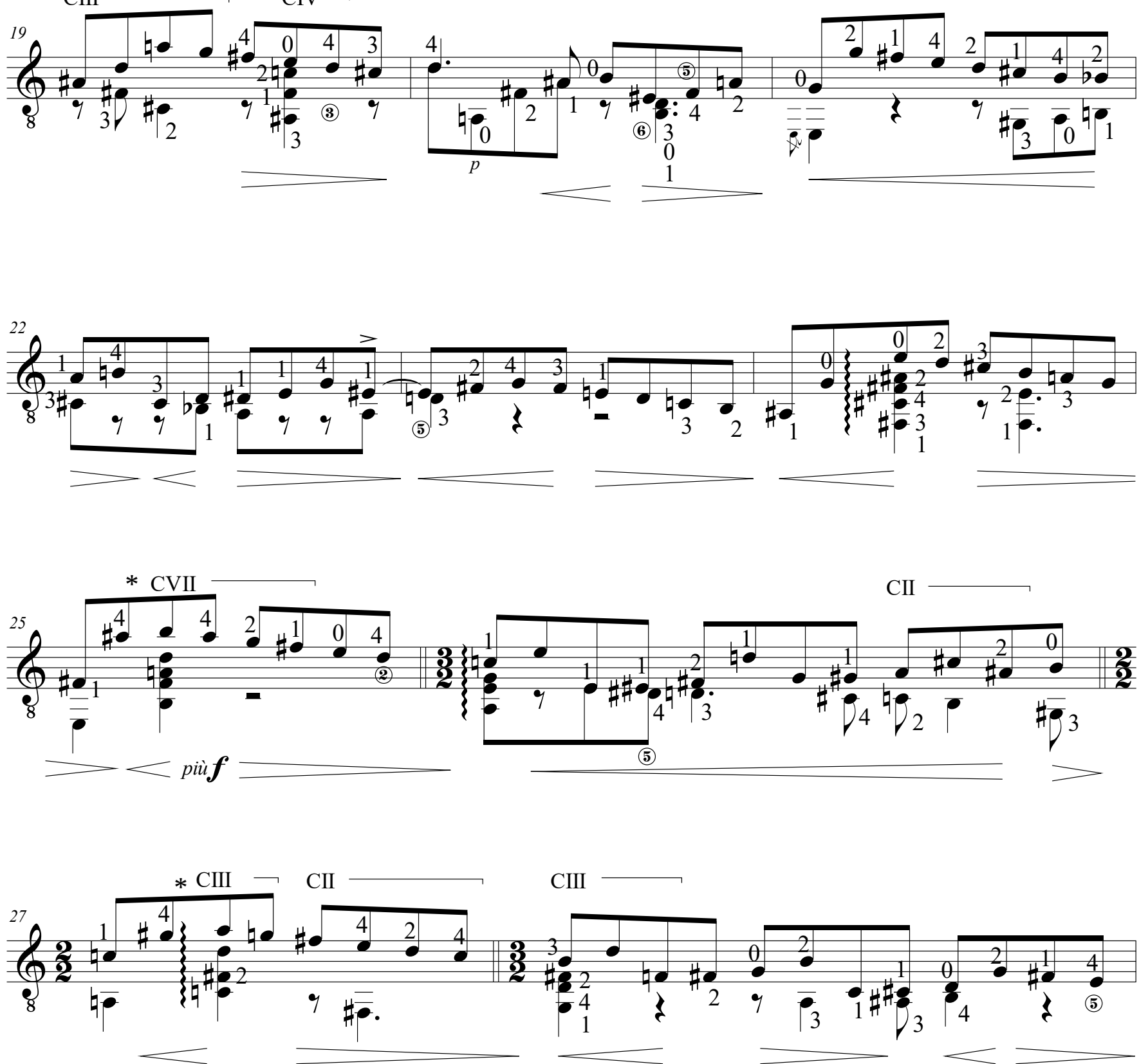
3
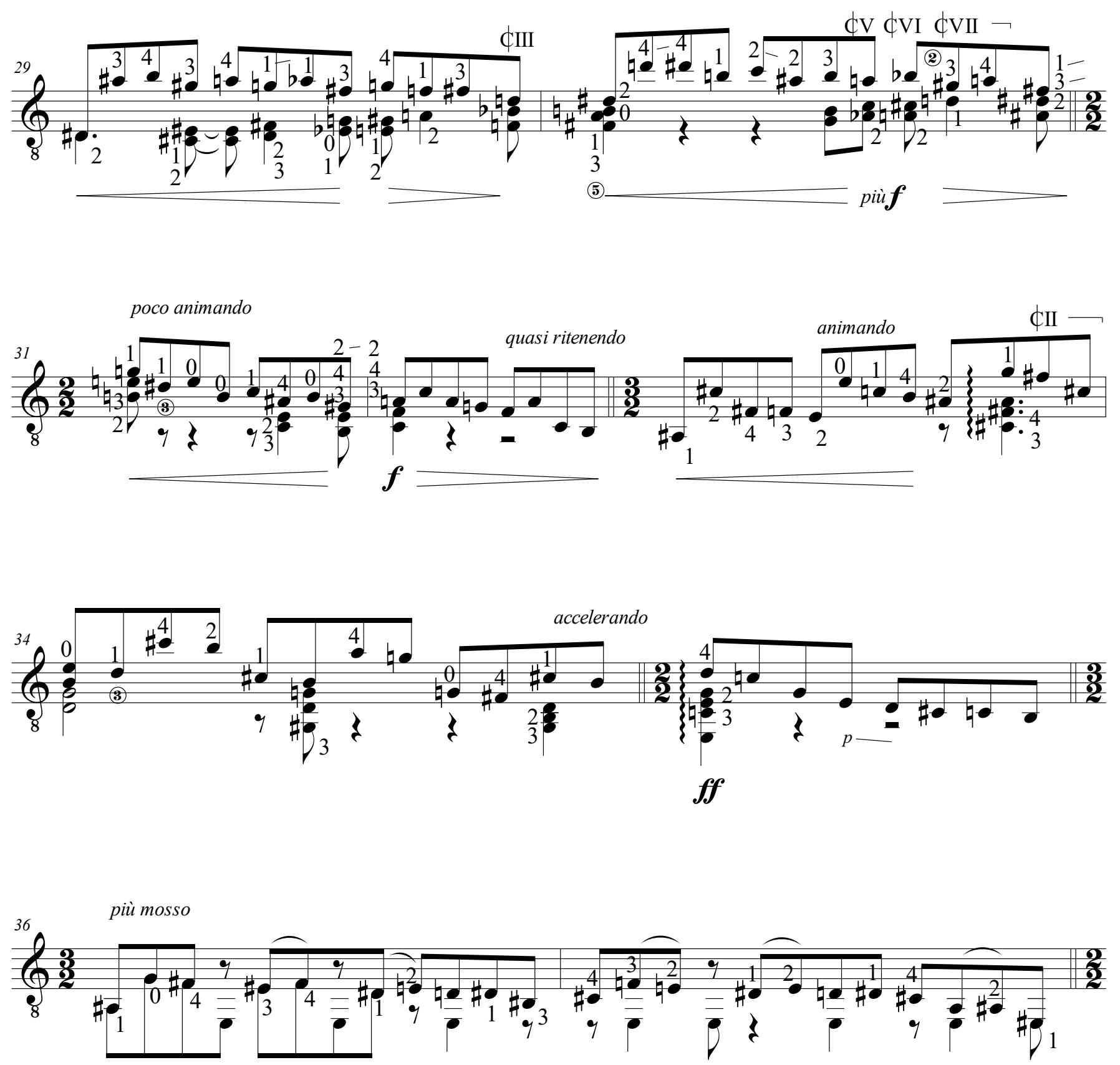

dim. poco a poco e ritenendo
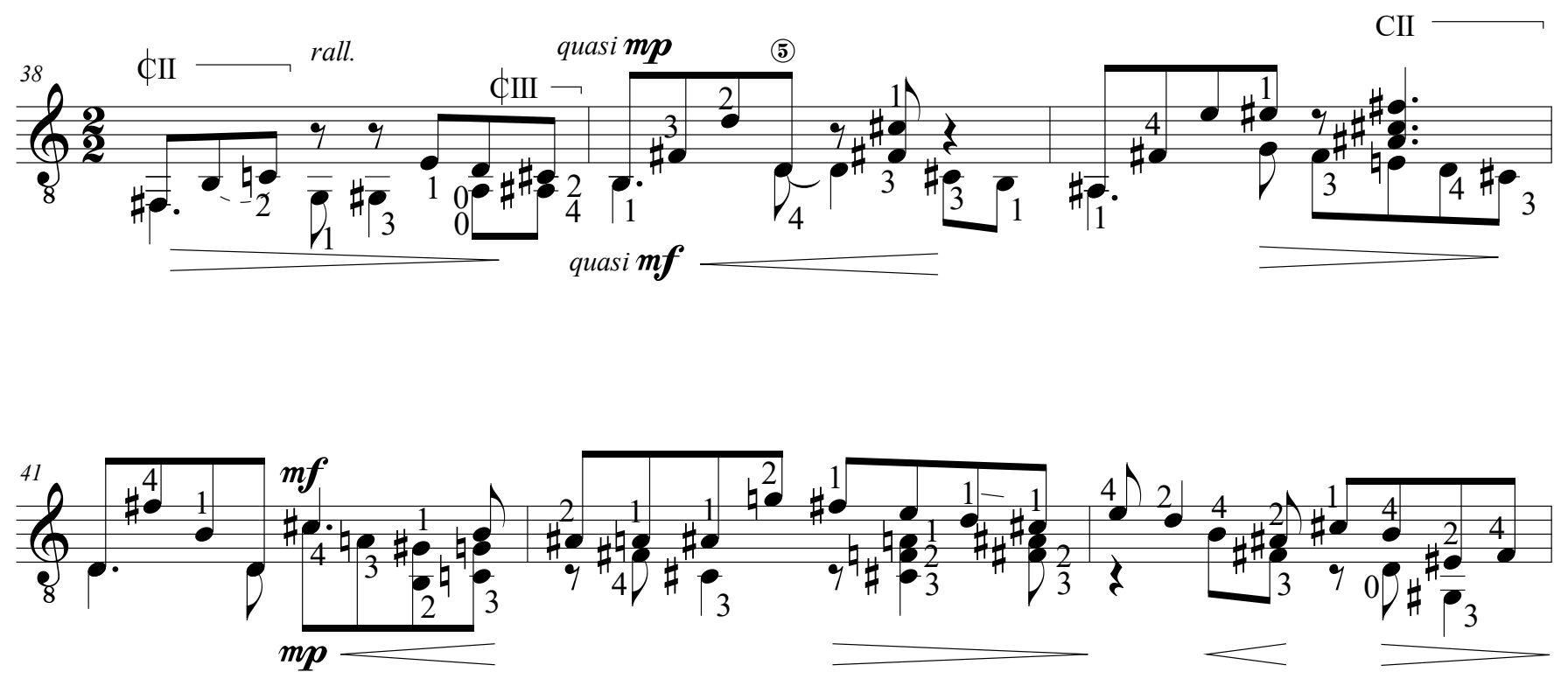

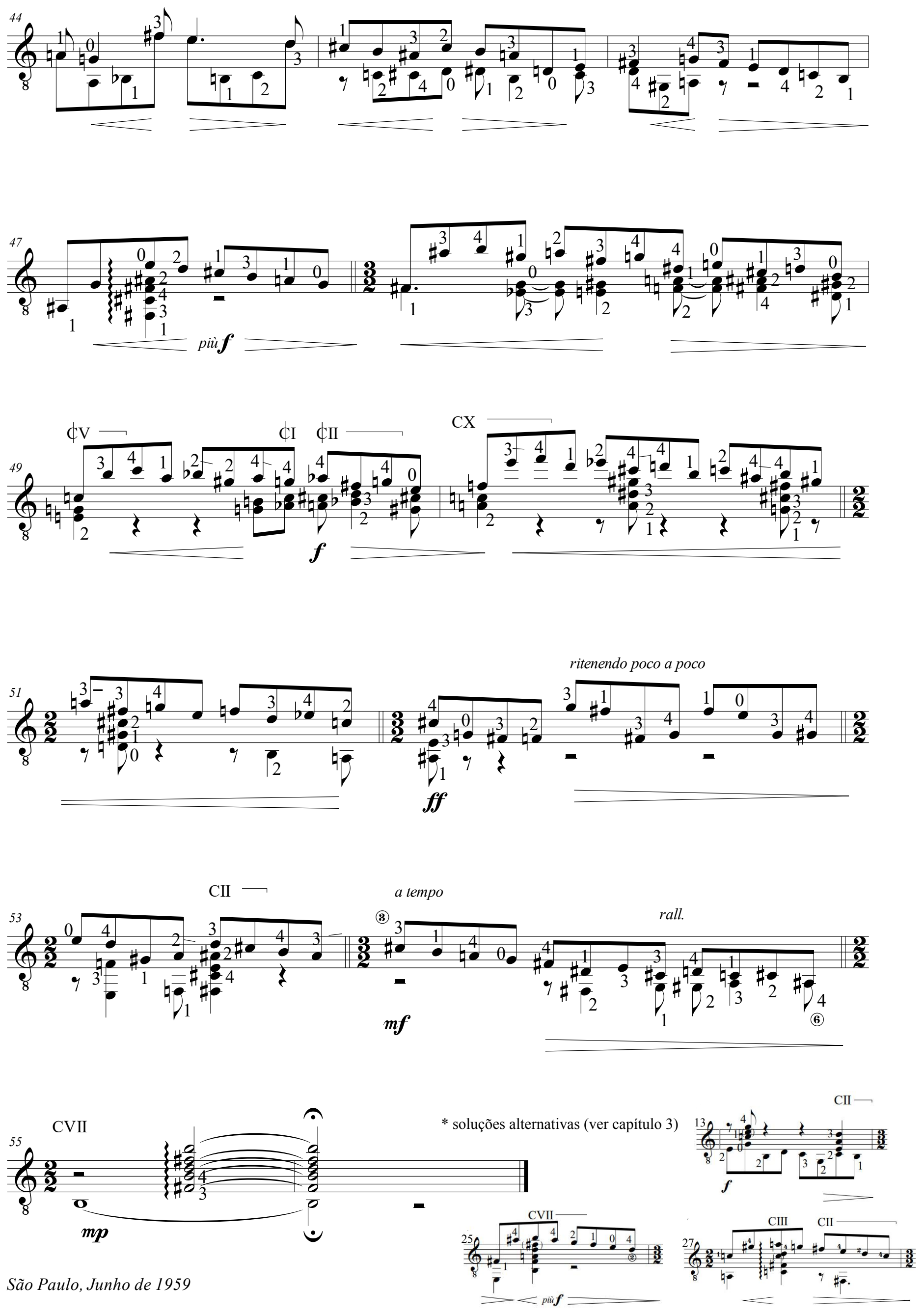
Revisão, edição e digitação:

Lucas Vieira e Edelton Gloeden

Expressivo $(\downarrow \pm 112)$, um pouco "rubato"
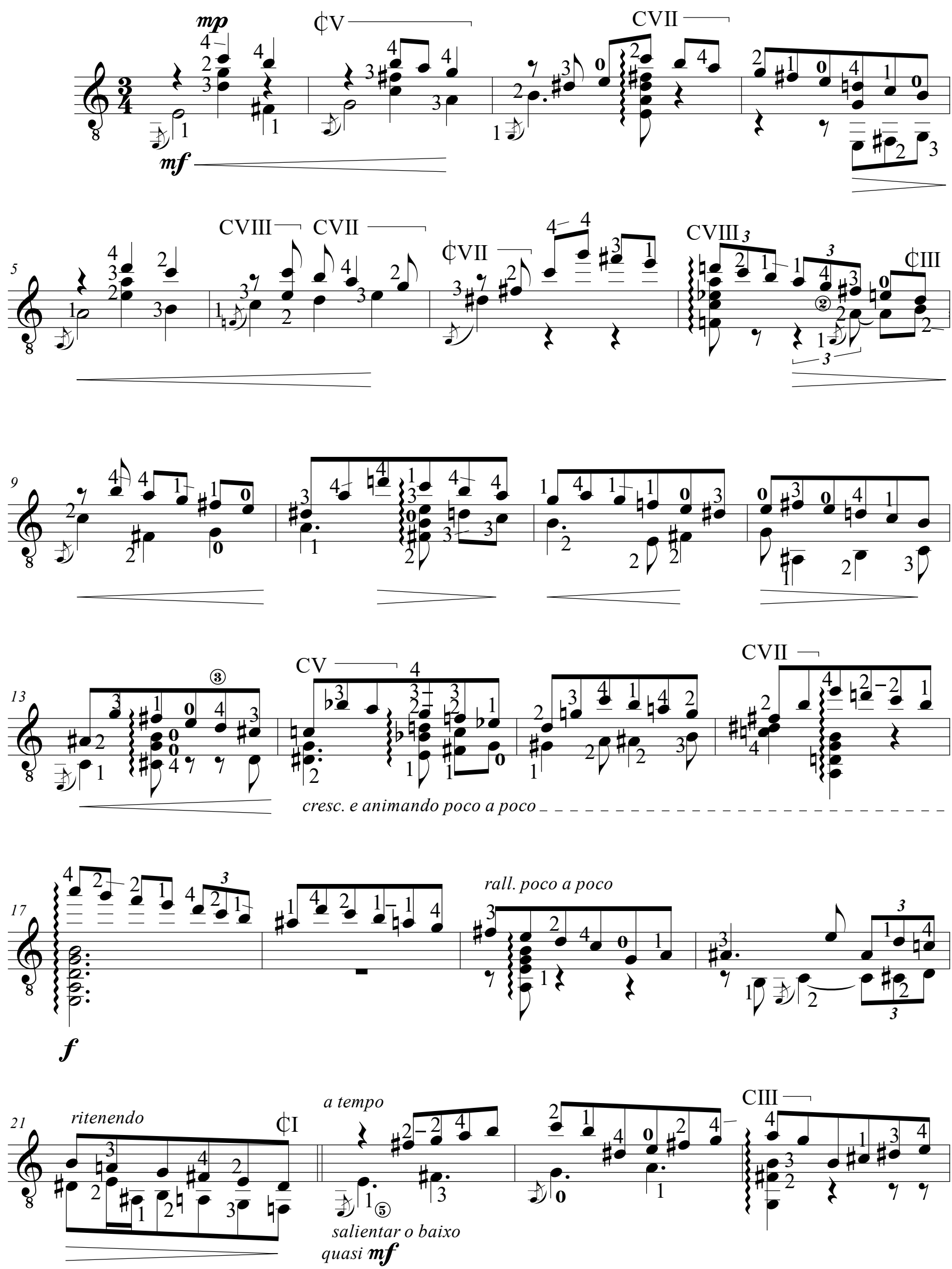

N.B. - Harpejar só os acordes marcados com a linha ondulada 


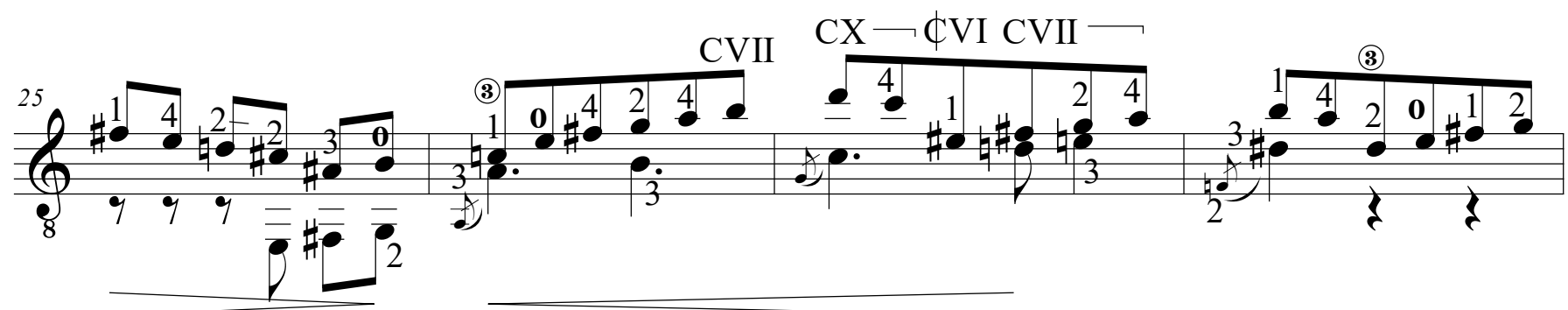
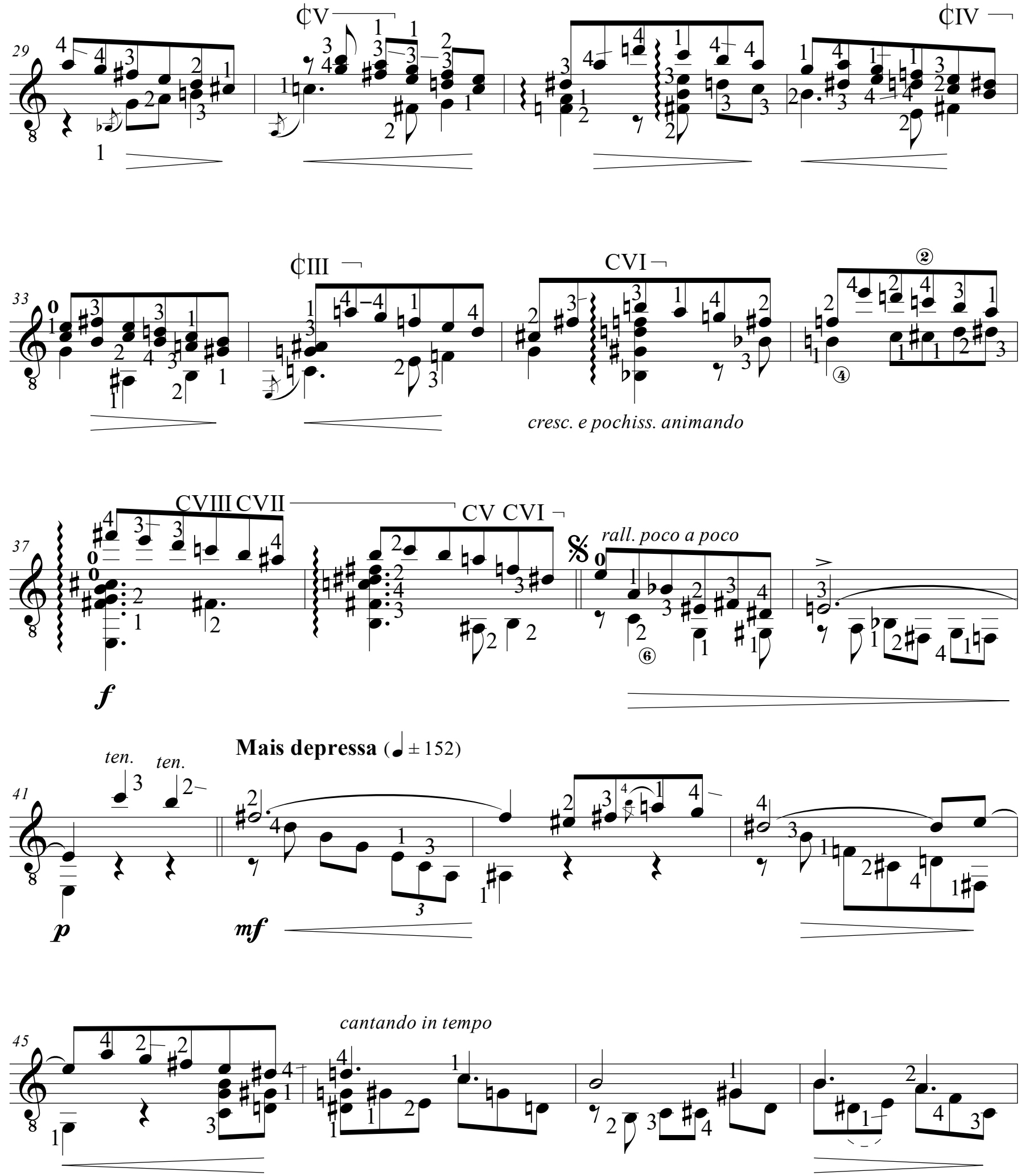

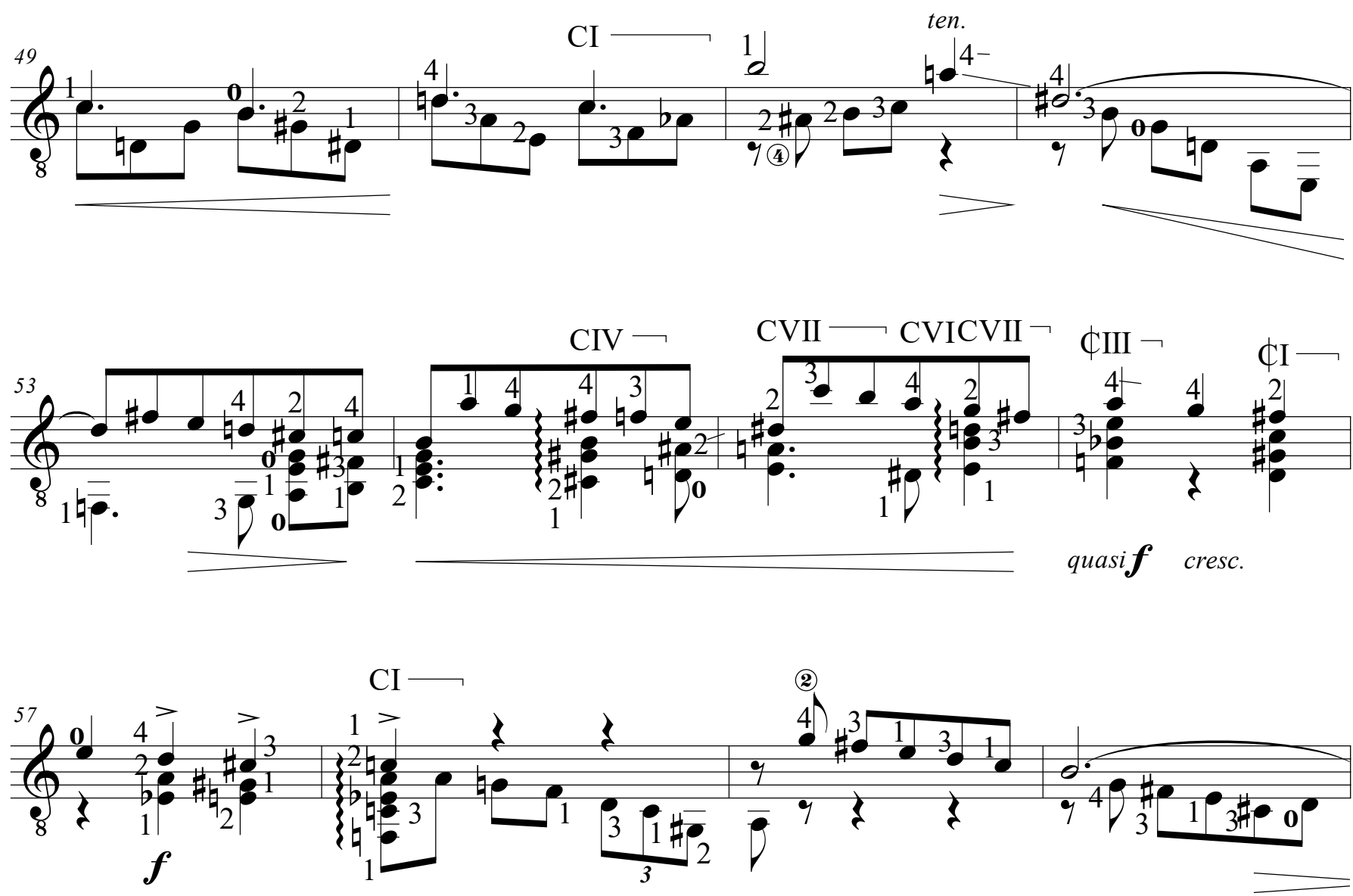

a tempo

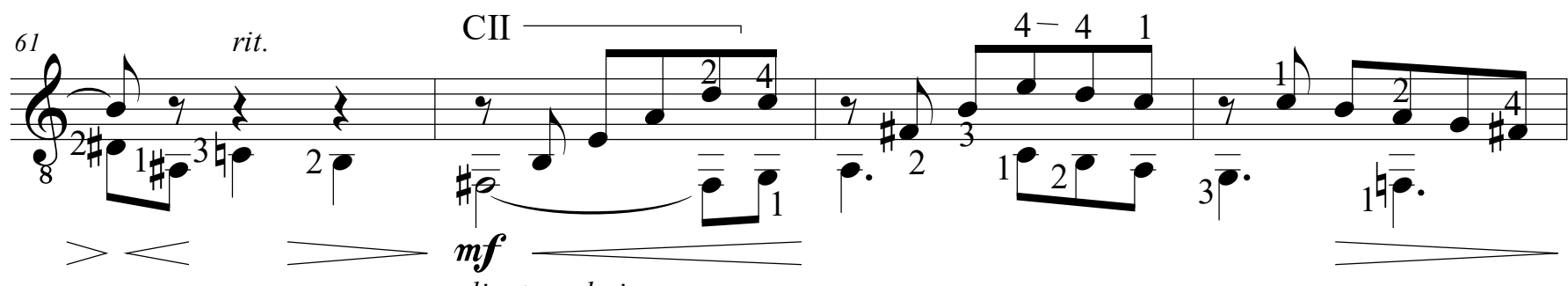
salientar o baixo
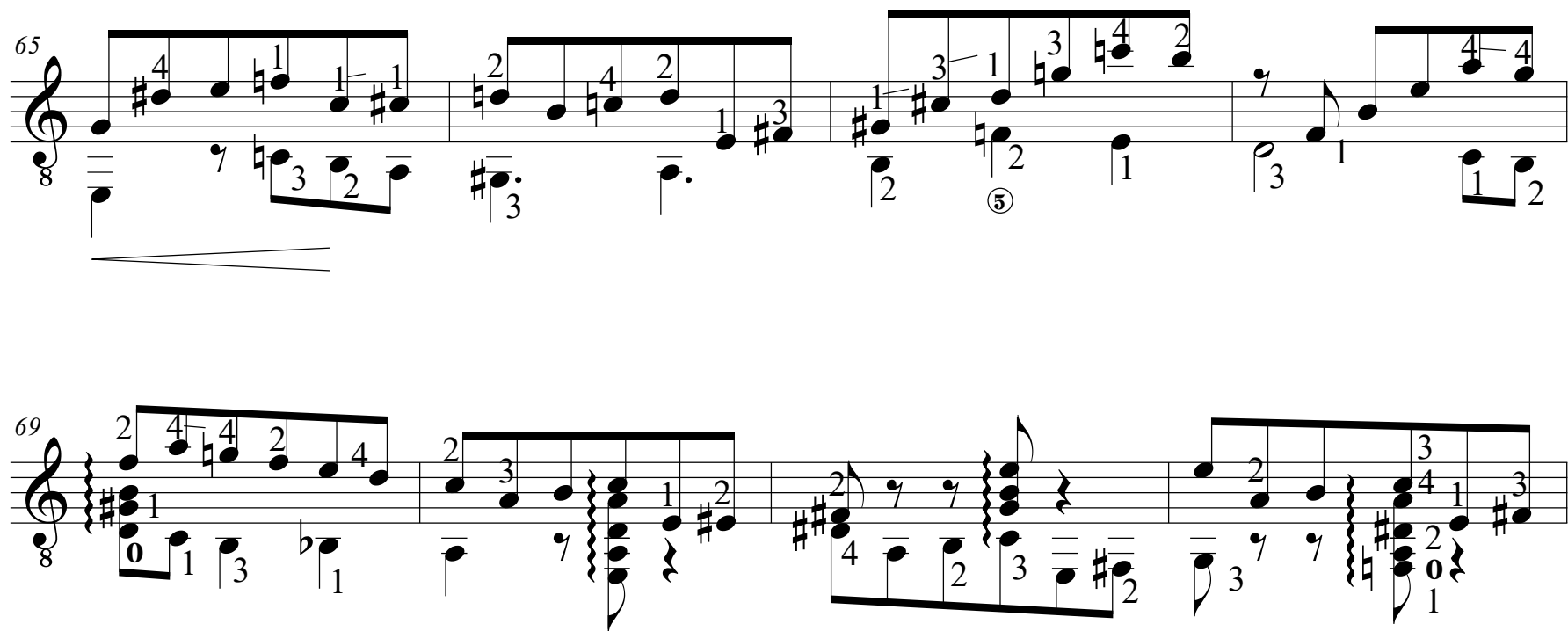

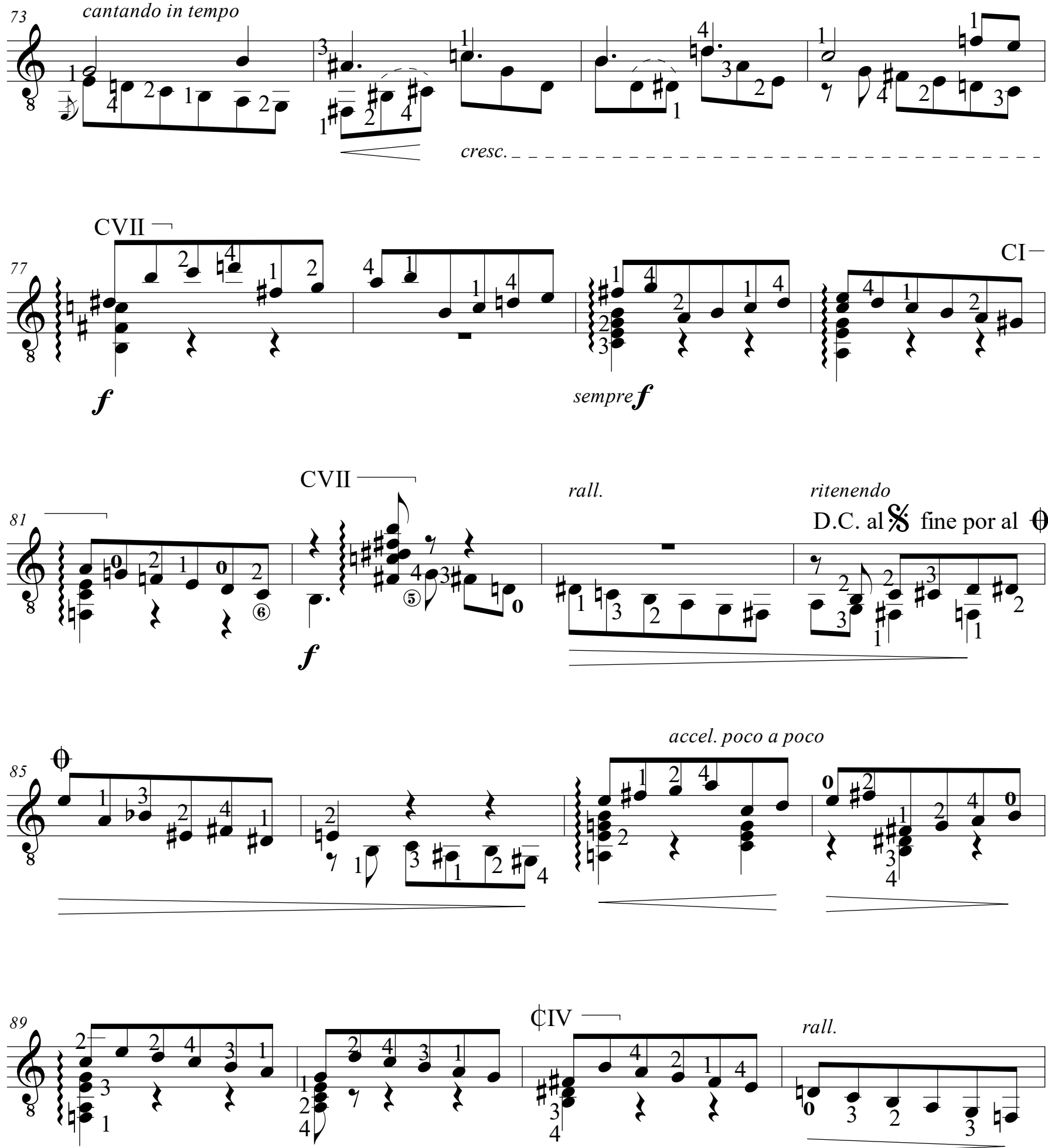

um pouco mais devagar

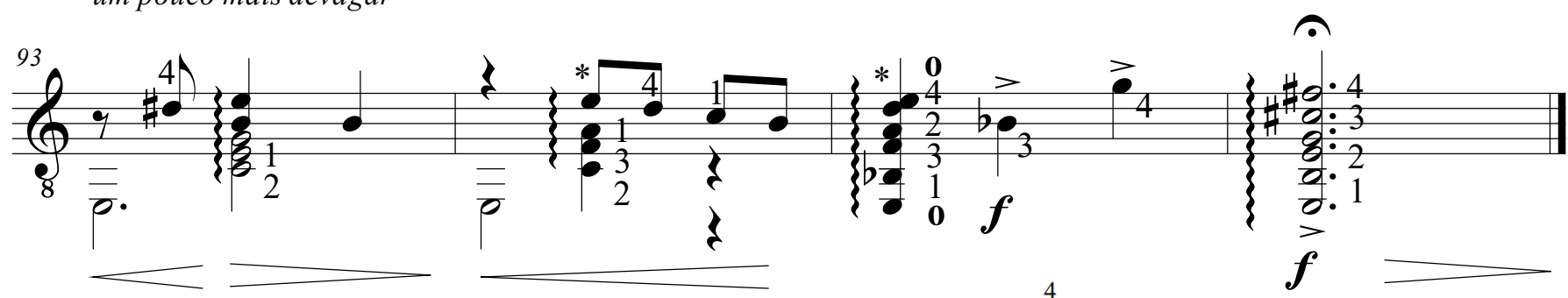

* soluções alternativas (ver capítulo 3) 


\section{MODA PAULISTA}

Revisão, edição e digitação:

Lucas Vieira e Edelton Gloeden

Osvaldo Lacerda

(1961)

Com animação $(\downarrow=96)$
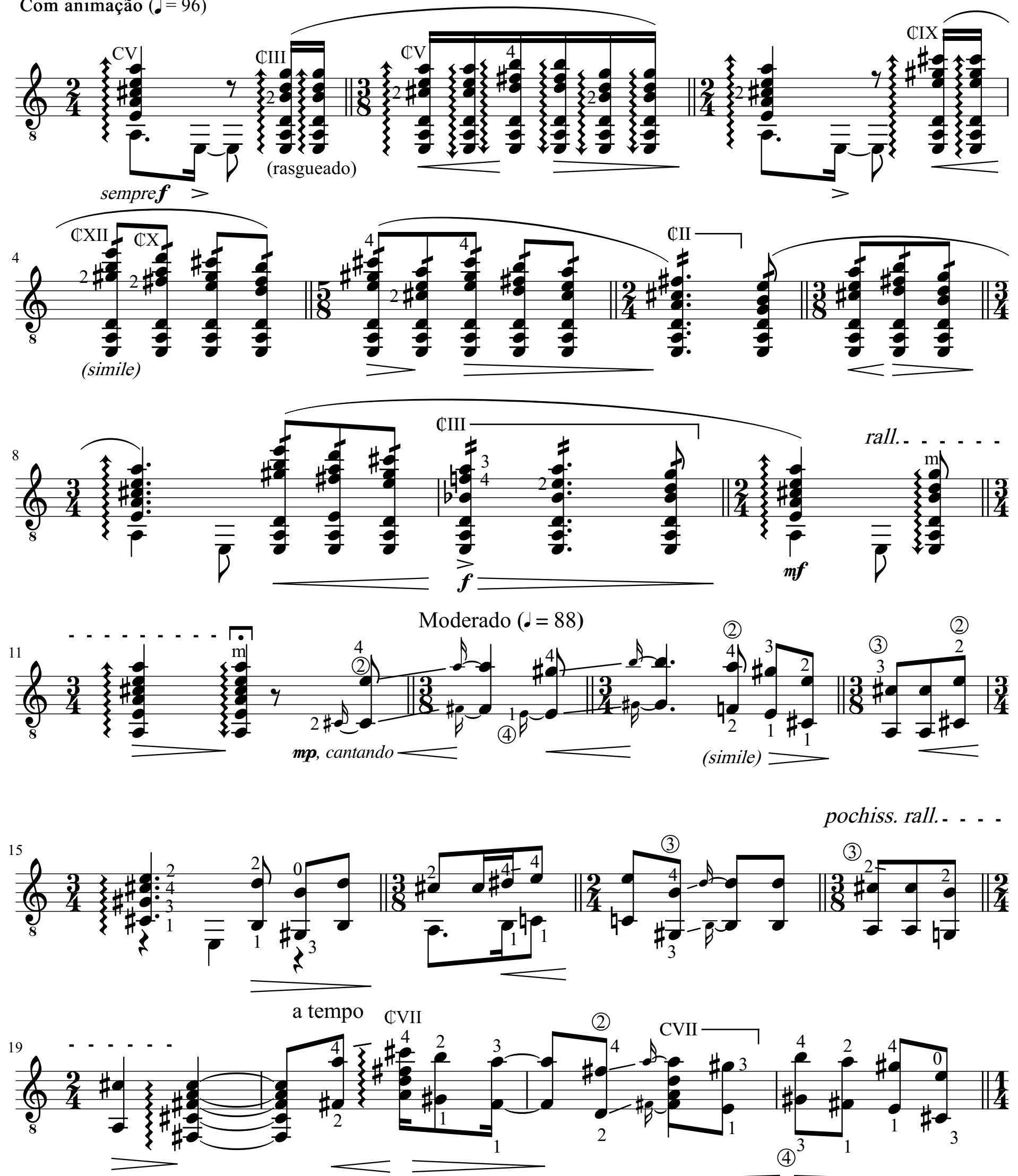
poco rit.

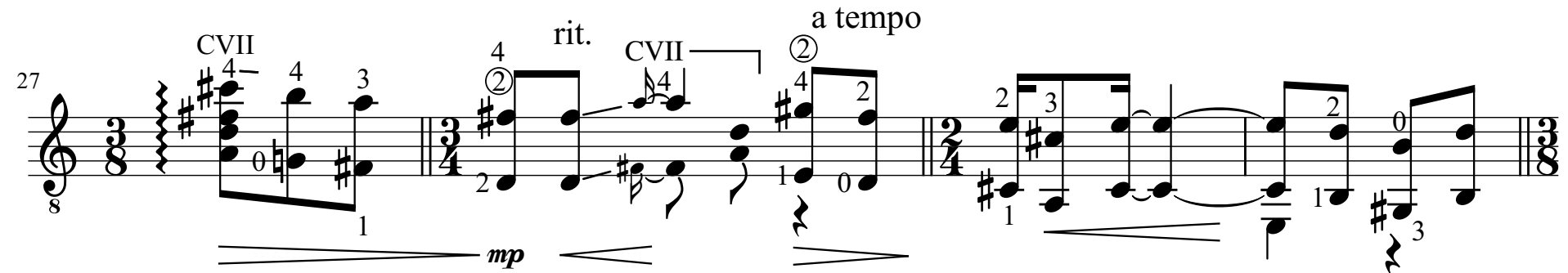

Com animação $(\cdot=96)$
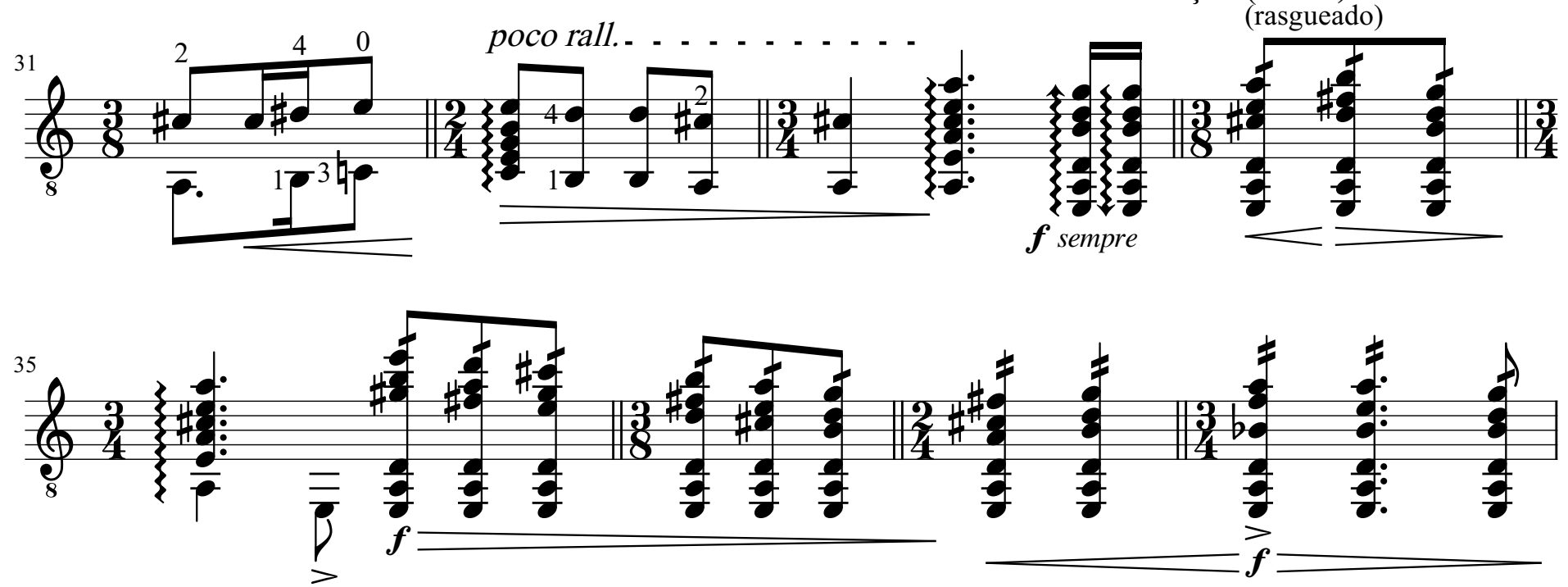
poco rall. . . . . . . Moderato $(\downarrow=88)$
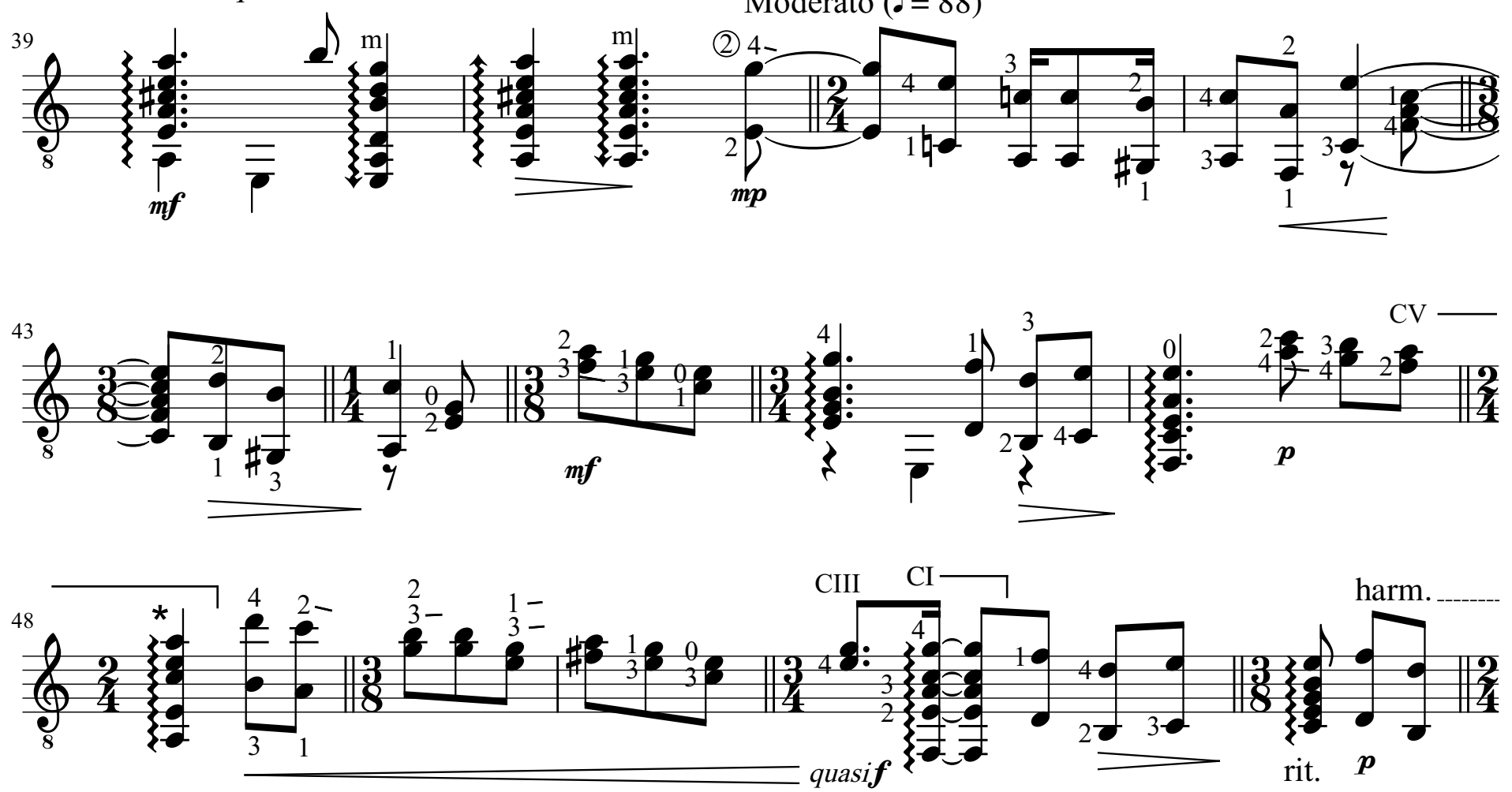

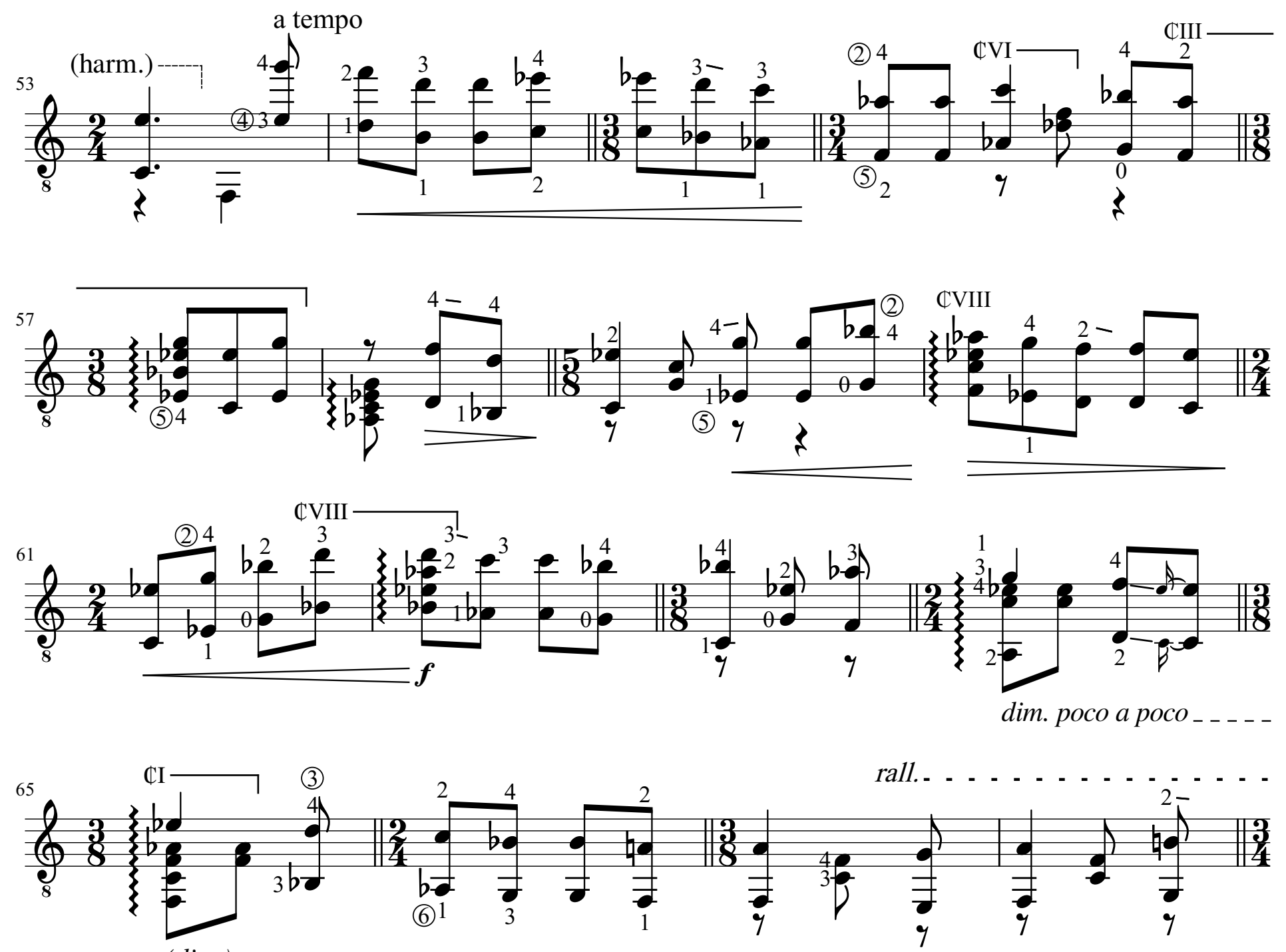

Com animação $(.=96)$
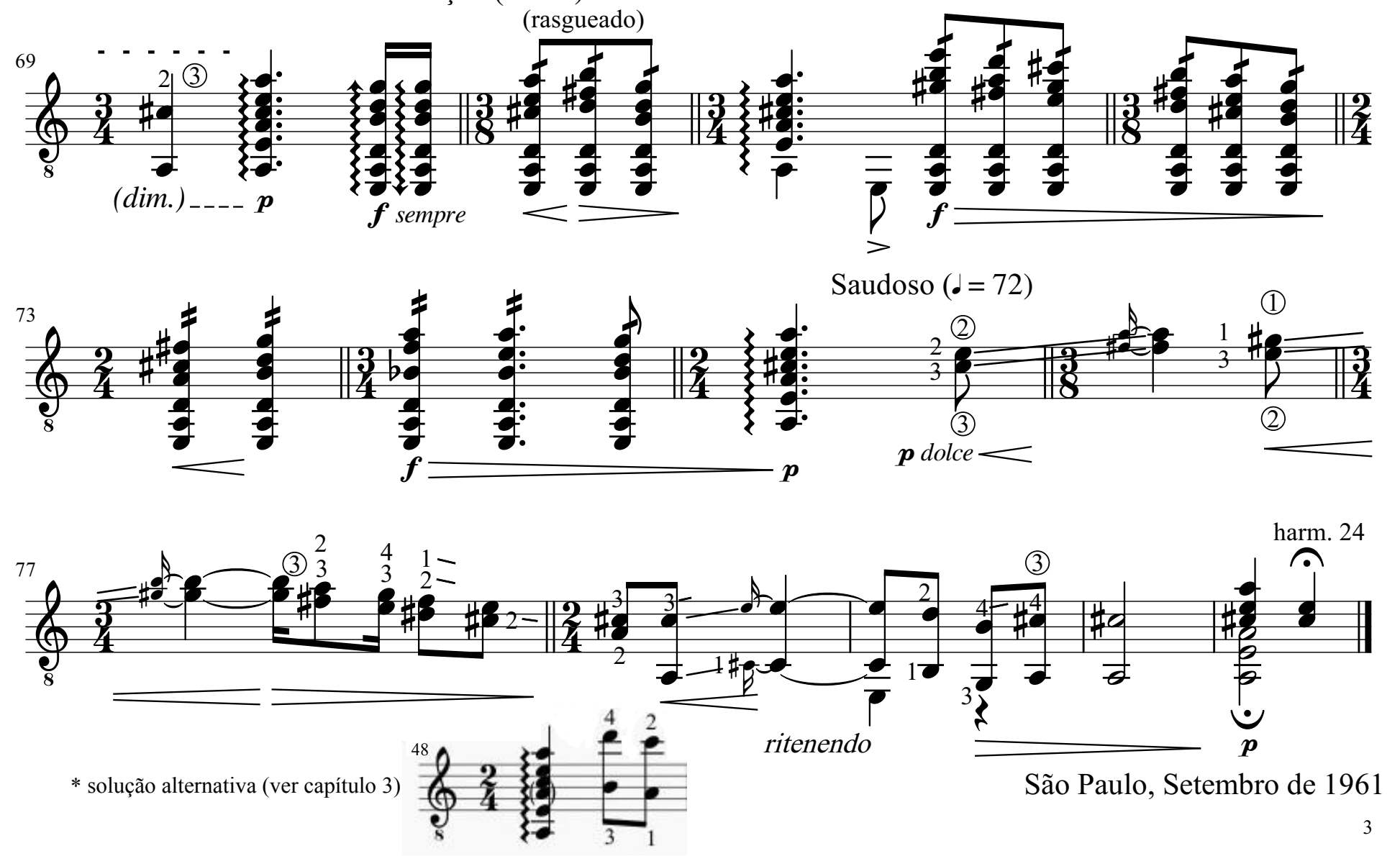
VOZ E VIOLÃO 


\title{
Osvaldo Lacerda
}

\section{"As dádivas" \\ (canto e violão)}

-1968-

\author{
A primeira vez \\ Dei-te um anel de sonho. \\ Nem o viste porque não crês. \\ E partiste. \\ A segunda vez \\ Dei-te um véu de carícias. \\ Tu cobriste tua nudez. \\ E partiste.
}

A terceira vez

Dei-te um colar de lágrimas.

Sorriste com altivez.

E partiste.

Mas a última vez

Nada te dei.

"É a última?"

Indagaste com timidez.

E ficaste. 


\title{
Osvaldo Lacerda
}

\author{
"Vácuo" \\ (canto e violão)
}

-1968-

Quís os teus olhos

Cheios de mistérios

Como dois hemisférios;

E as tuas mãos

Gesticulando a bençam

Como espirais

Que incensam;

E nos teus lábios

Uma outra metade

De uma única verdade:

E tive ôcos na vida

Ainda mais ôca

O olhar, o gesto, e a boca,

O olhar, o gesto, e a boca.

Texto: Guilherme de Almeida

Duração aproximada: 1'05 


\title{
Osvaldo Lacerda
}

\author{
"Saudade" \\ (canto e violão)
}

$-1968-$

I. Saudade quasi se explica Nesta trova que te dou:

Saudade é a falta que fica

Daquilo que não ficou,

Daquilo que não ficou.

II. Saudade, palavra doce,

Que traduz tanto amargor!

Saudade é como se fosse

Espinho cheirando a flor,

Espinho cheirando a flor.

III. A saudade que se sente

De um amor que se perdeu,

É a homenagem do presente

Ao passado que morreu,

Ao passado que morreu.

IV. e é triste sentir saudade,

Muita saudade de alguém,

Maior infelicidade

É não tê-la de ninguém,

É não tê-la de ninguém.

Texto: Diversos autores Duração aproximada: 2’00 
Texto de Guilherme de Almeida

Edição, revisão e digitação:

Lucas Vieira e Edelton Gloeden

\section{As dádivas}

(canto e violão)
Osvaldo Lacerda

(1968)
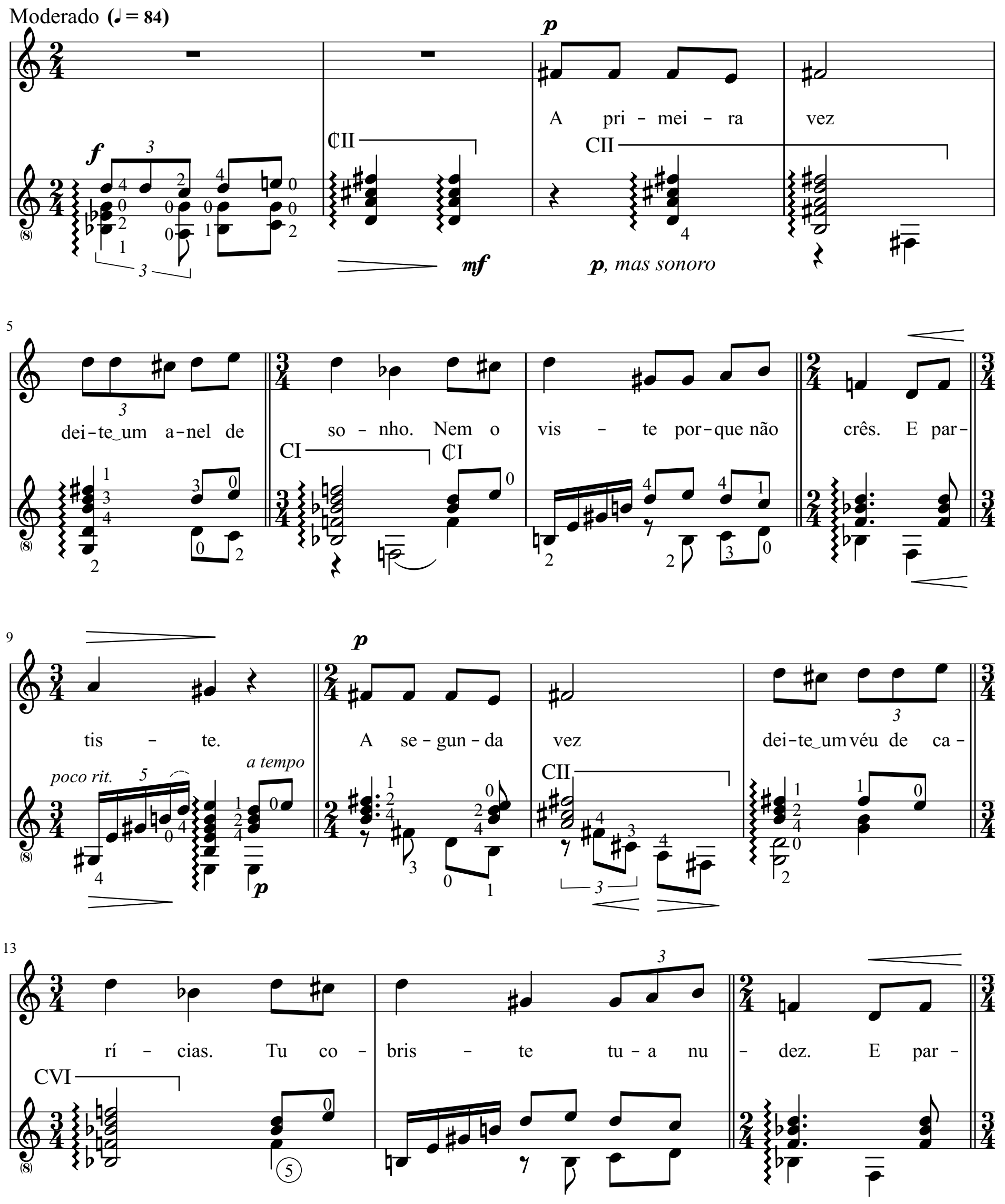

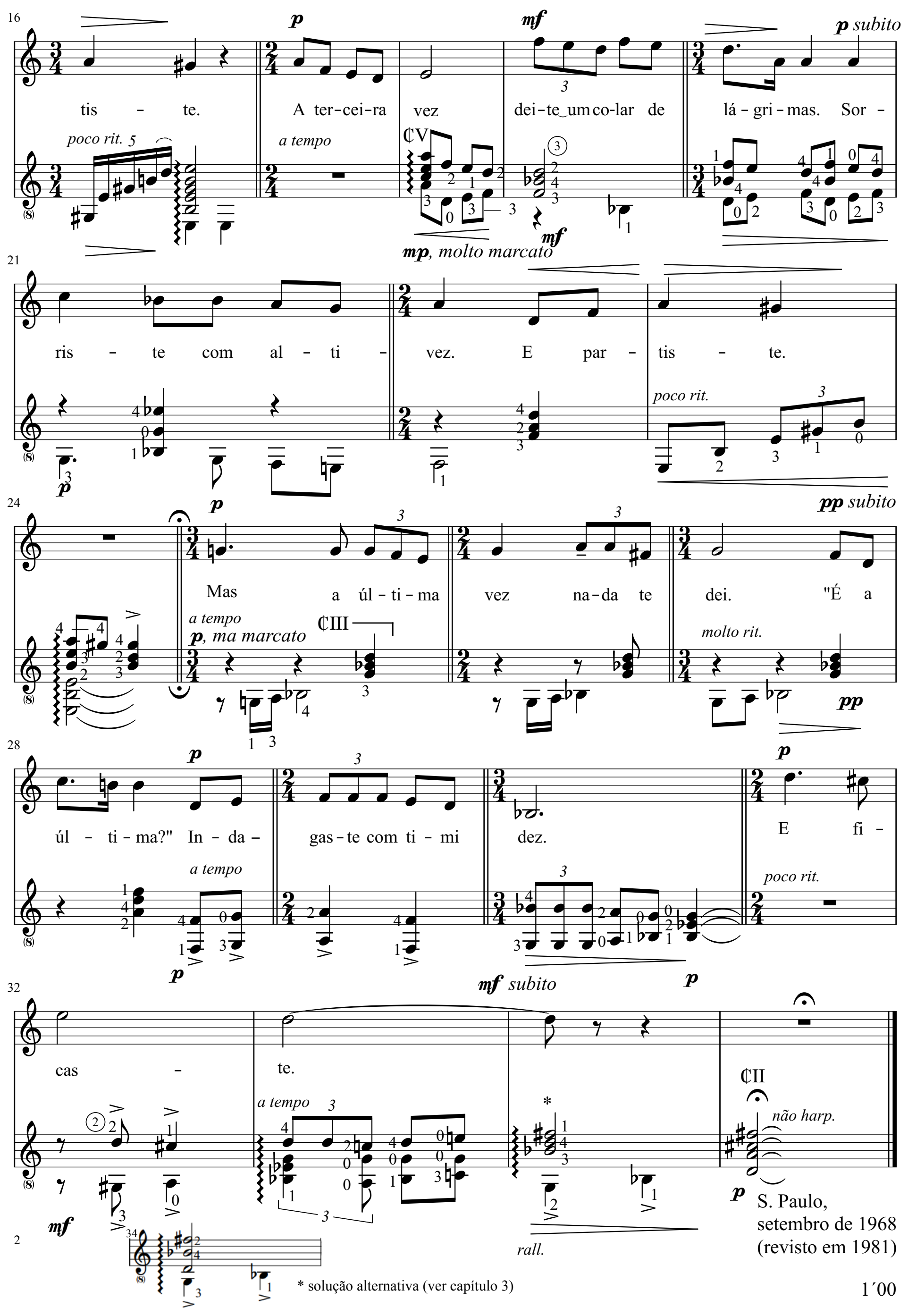
Texto de Guilherme de Almeida

Edição, revisão e digitação:

Lucas Vieira e Edelton Gloeden

\section{Vácuo}

(canto e violão)
Osvaldo Lacerda

(1968)

Moderado $(\downarrow=84)$

84

2
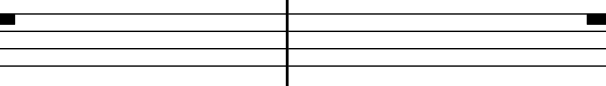

$\boldsymbol{m} \boldsymbol{f}$, sempre marcato

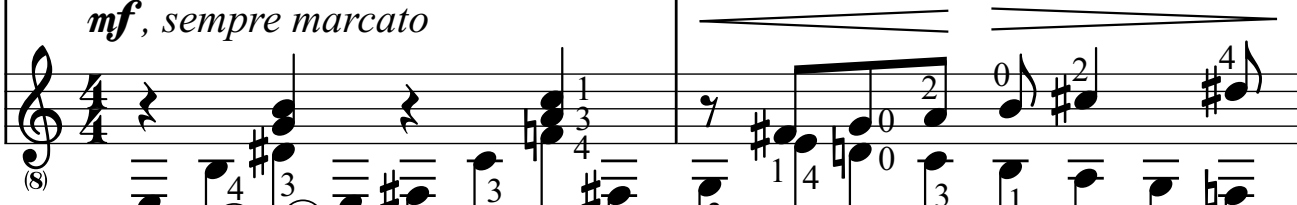
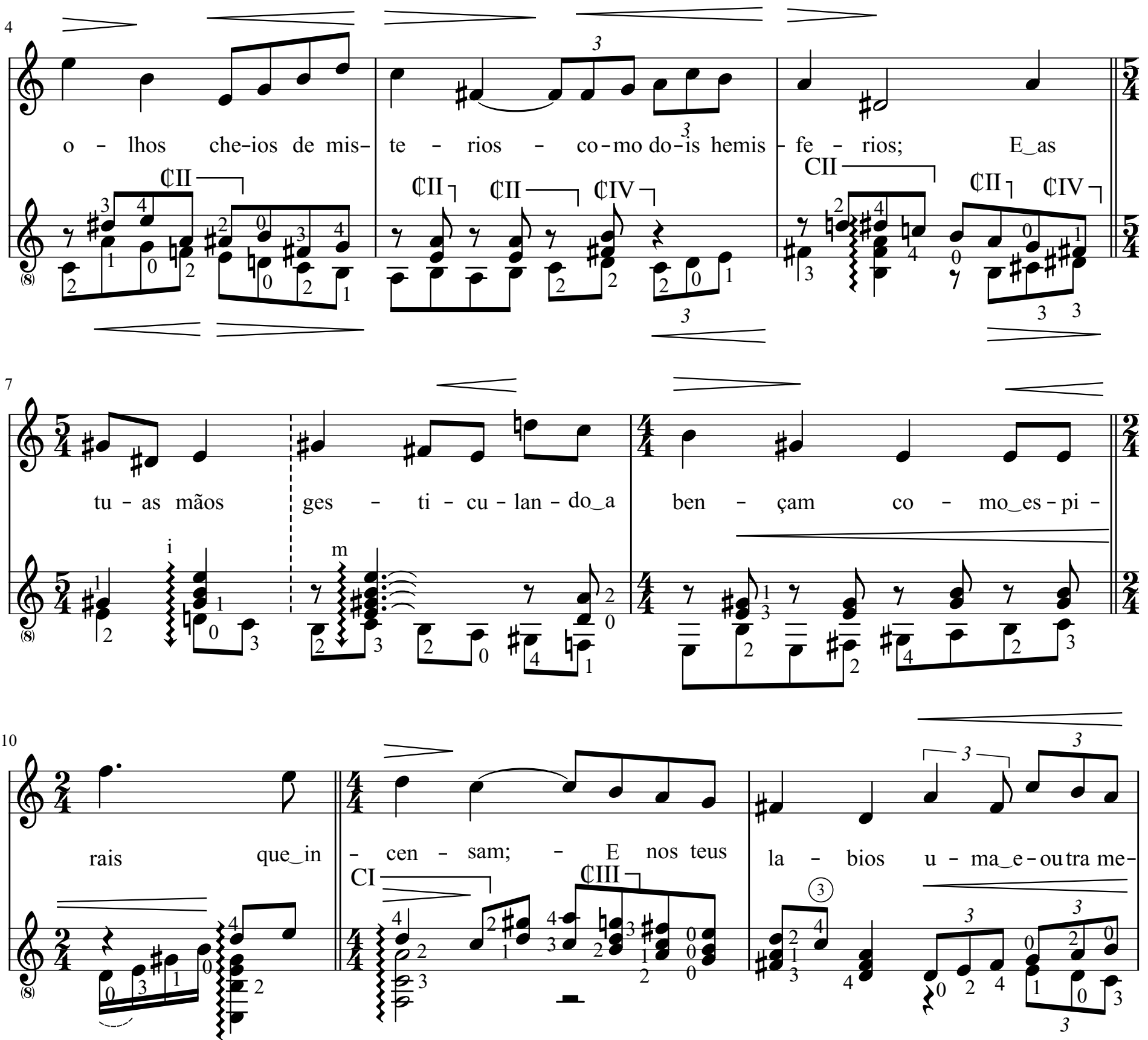

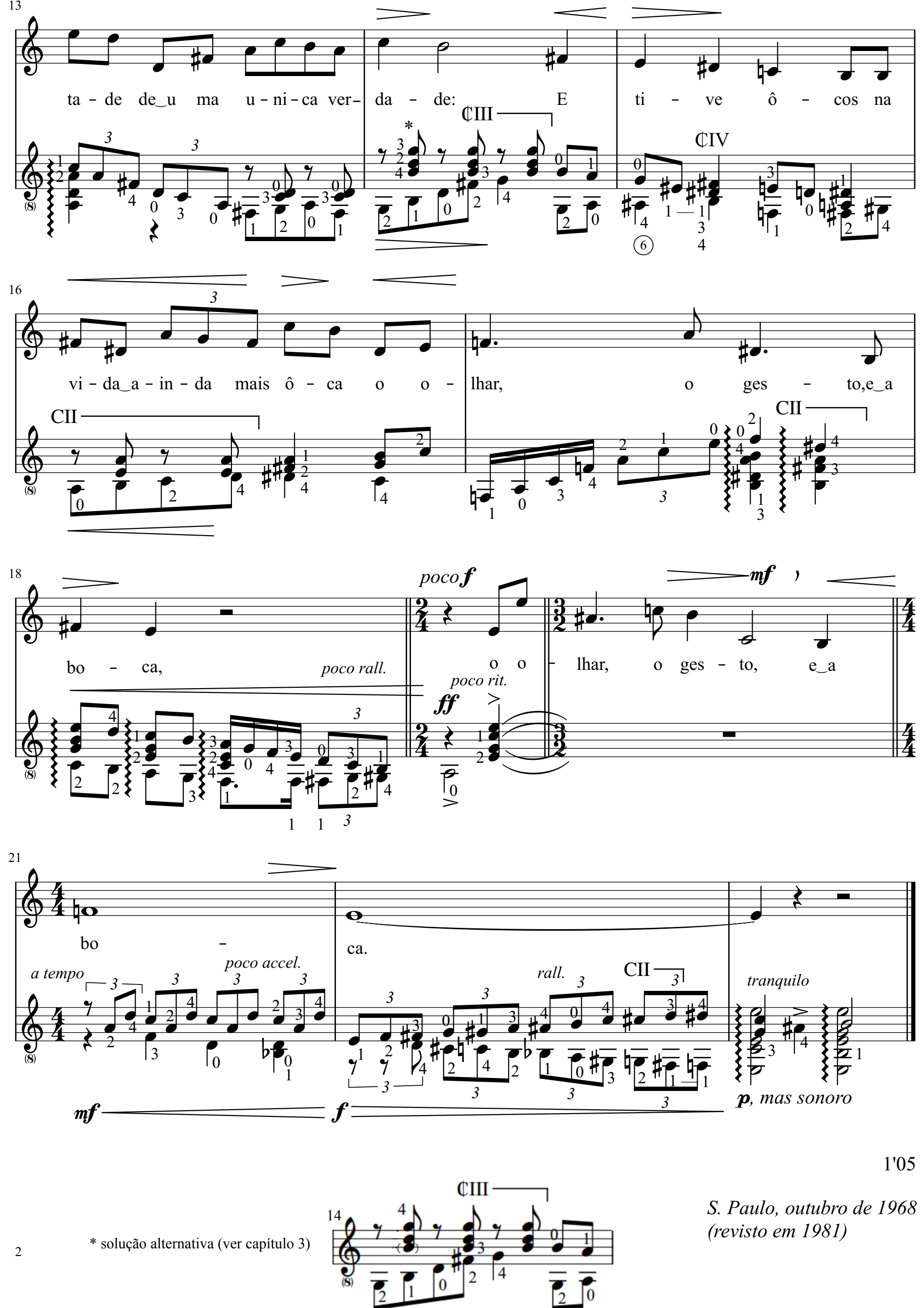

S. Paulo, outubro de 1968 (revisto em 1981) 
Texto de diversos autores

Edição, revisão e digitação:

Lucas Vieira e Edelton Gloeden

Animado $(\cdot=104)$
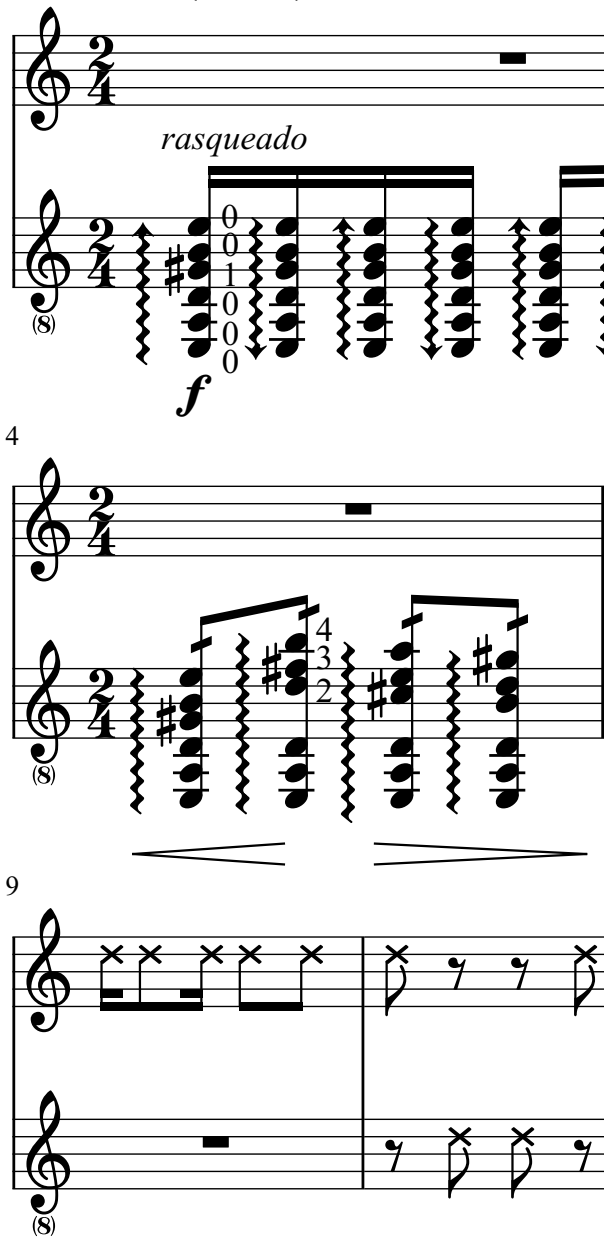

\section{Saudade}

(canto e violão)

"No jeito de um cateretê"

Osvaldo Lacerda

(1968)

$$
(\diamond=\varnothing)
$$

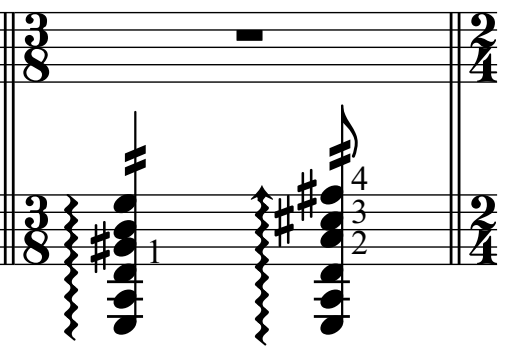

batendo palmas

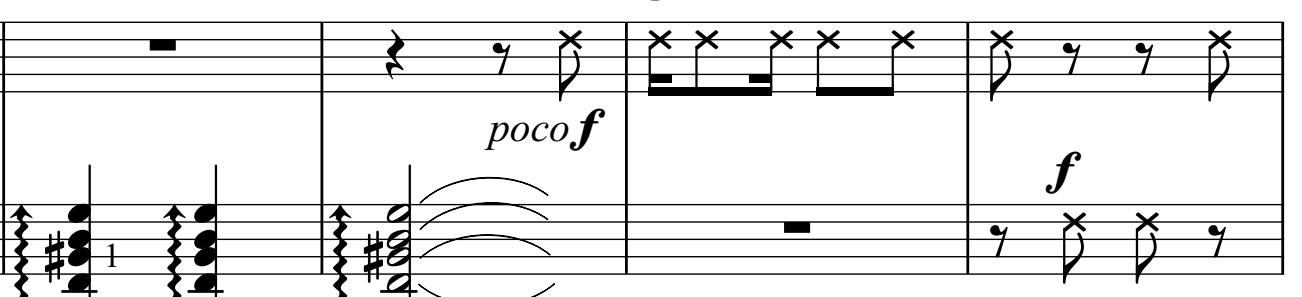

batendo sobre o cavalete, e abafando as cordas com a mão esquerda
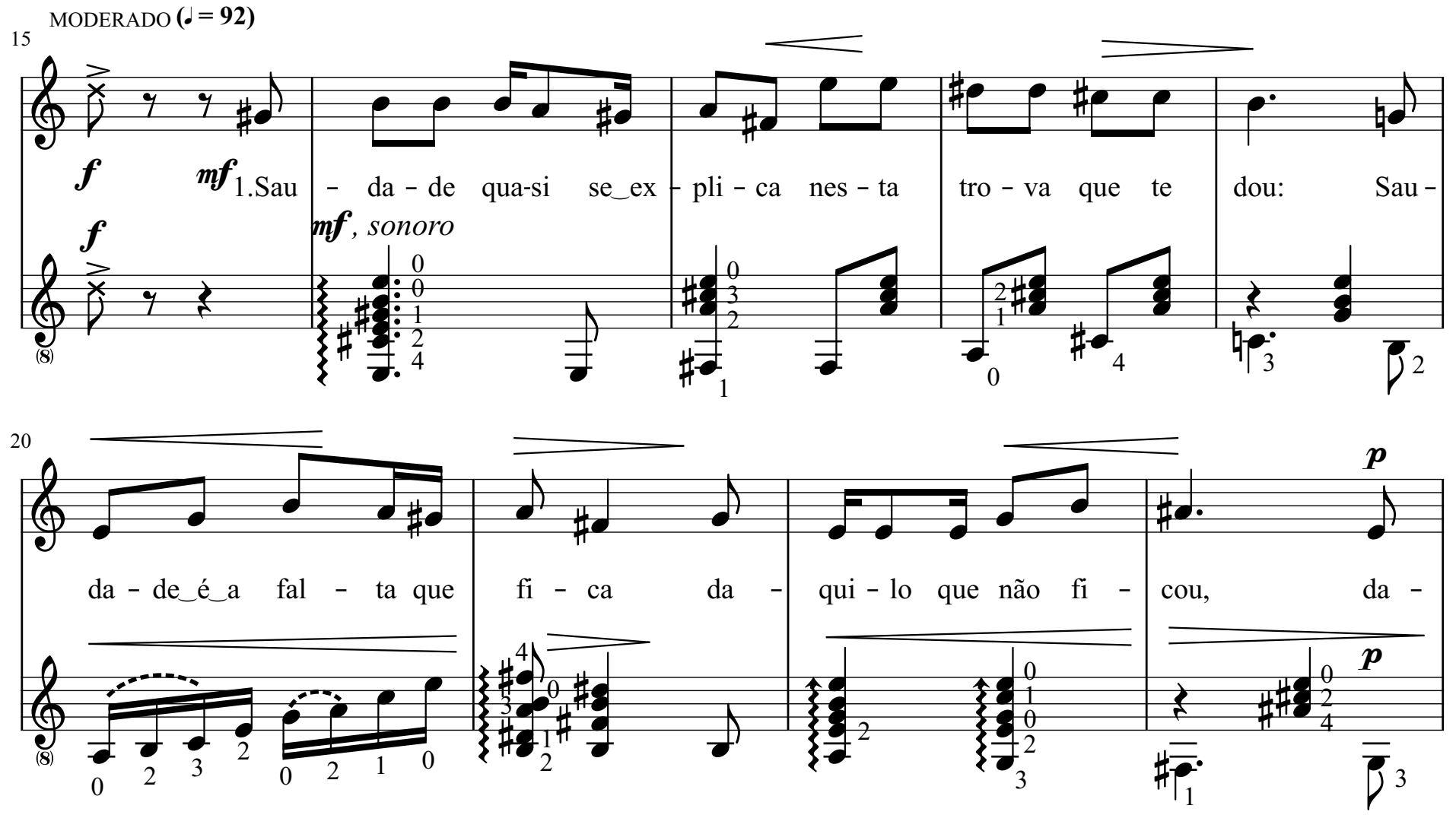

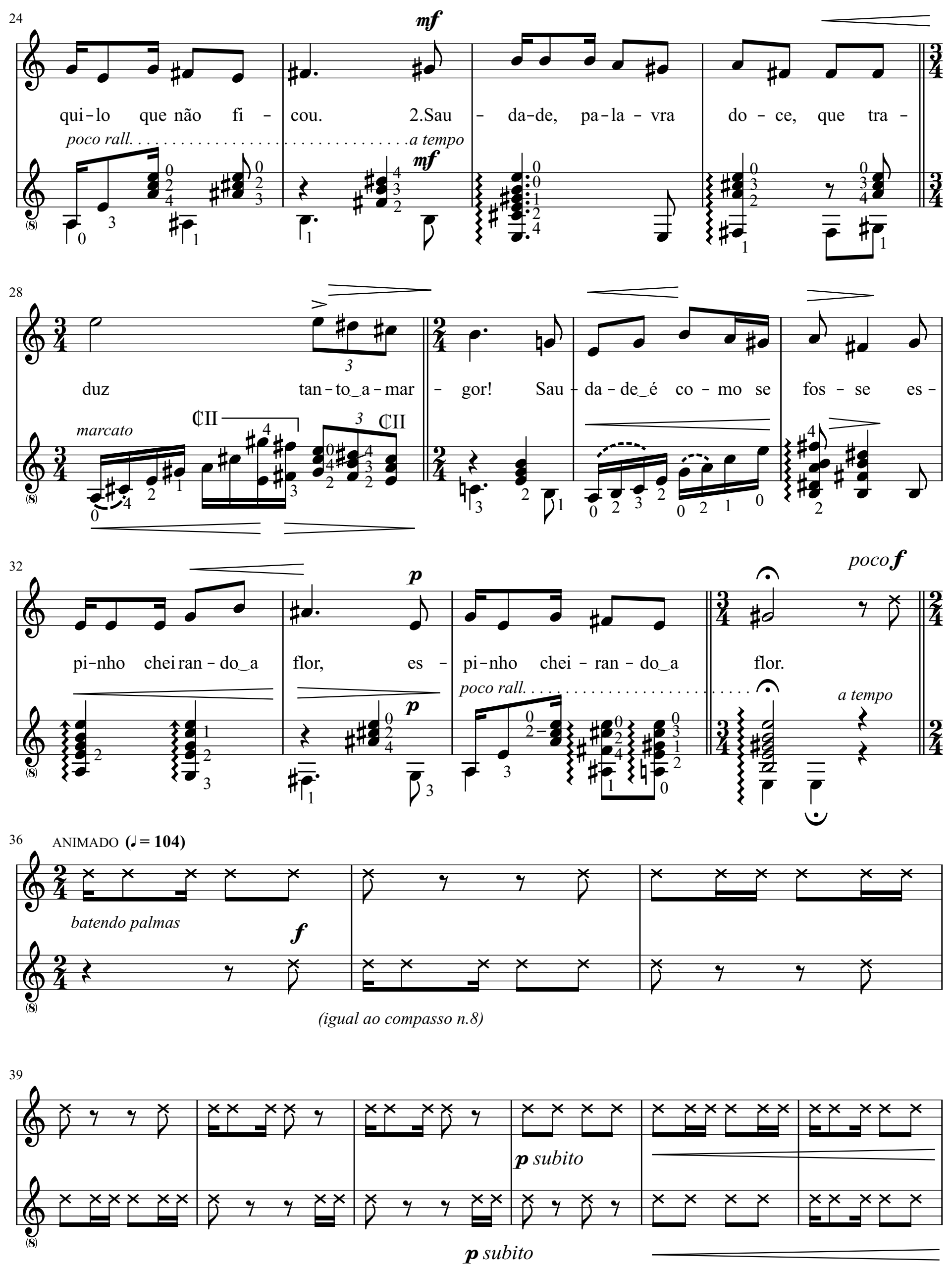
45 MODERADO $(\boldsymbol{\sigma}=\mathbf{9 2})$

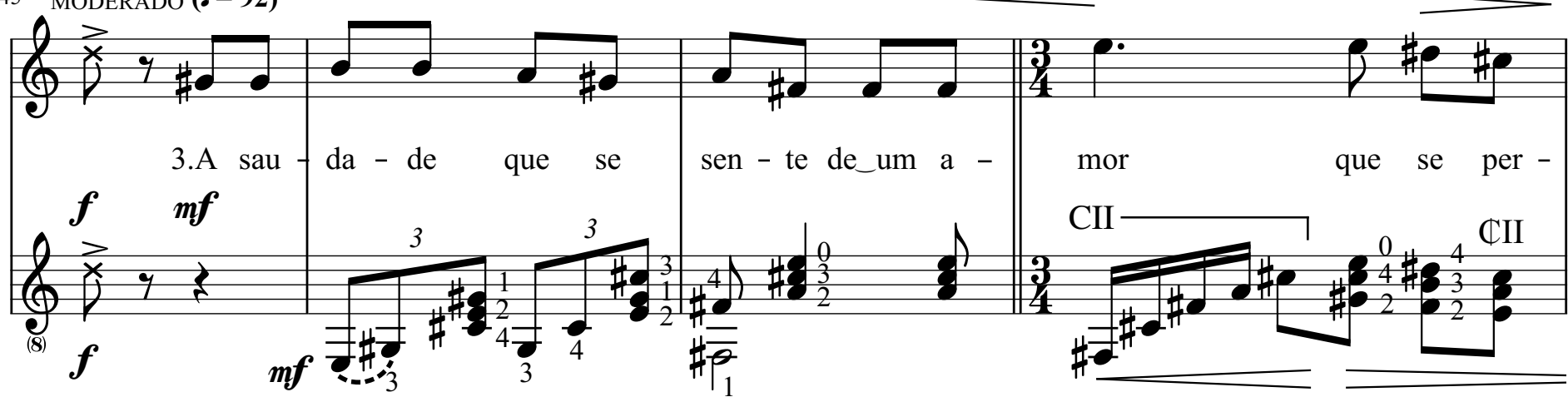

49

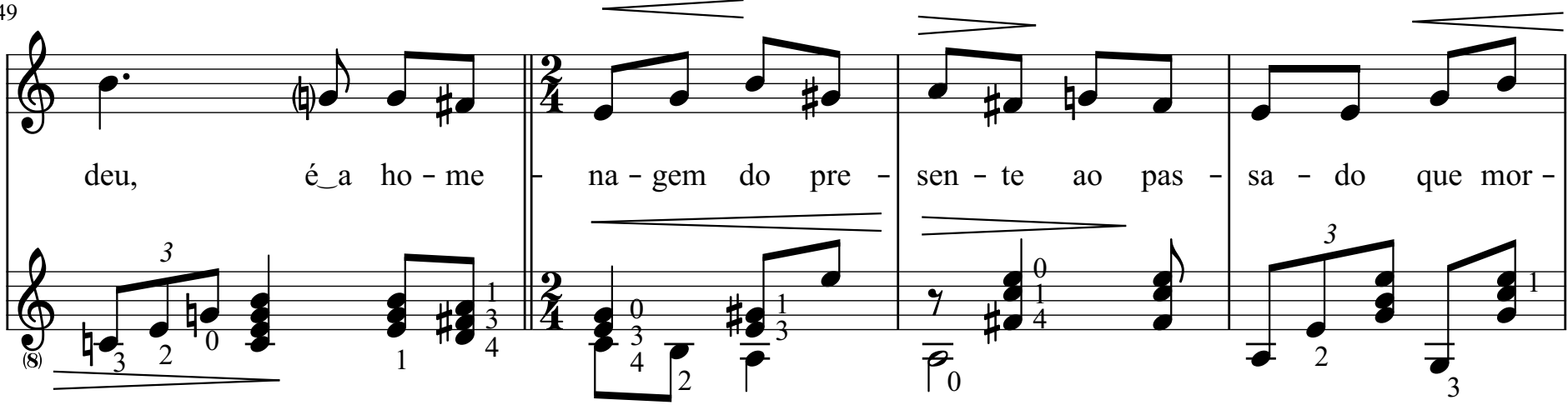

53
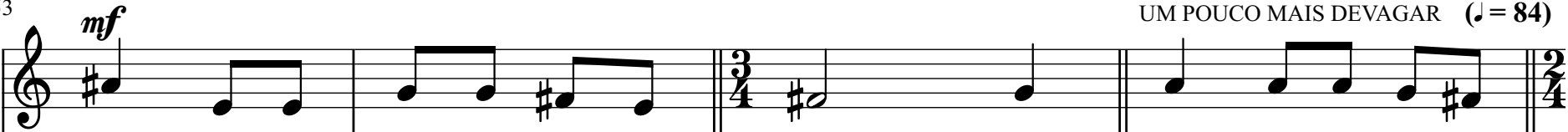

reu, ao pas - sa - do que mor - reu. 4.Se_é

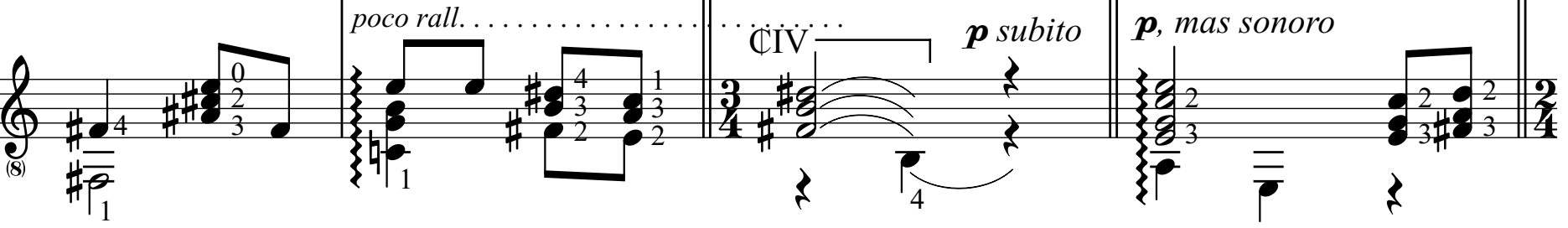

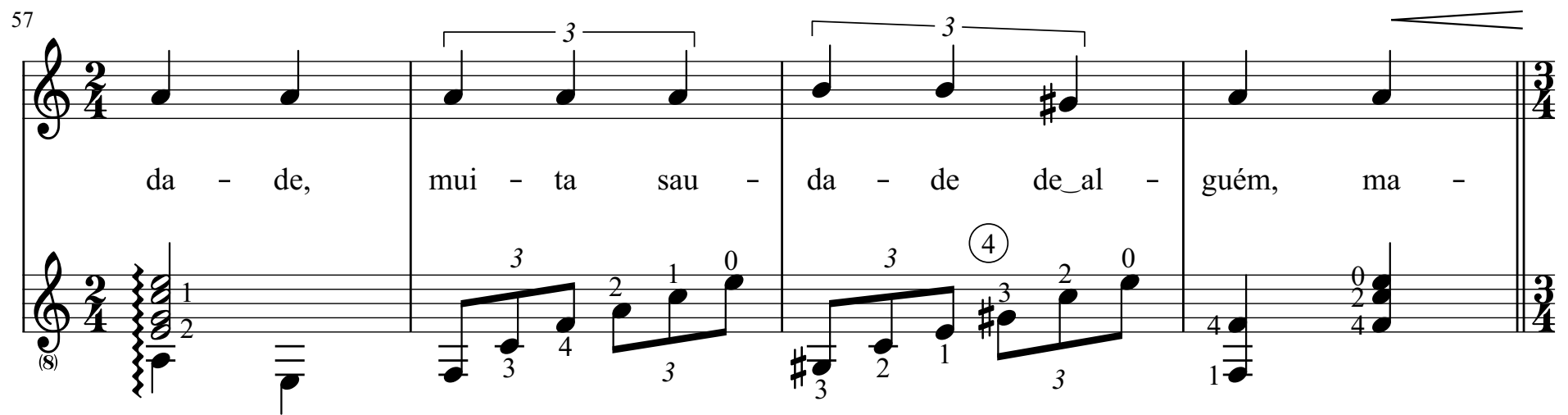

pp subito

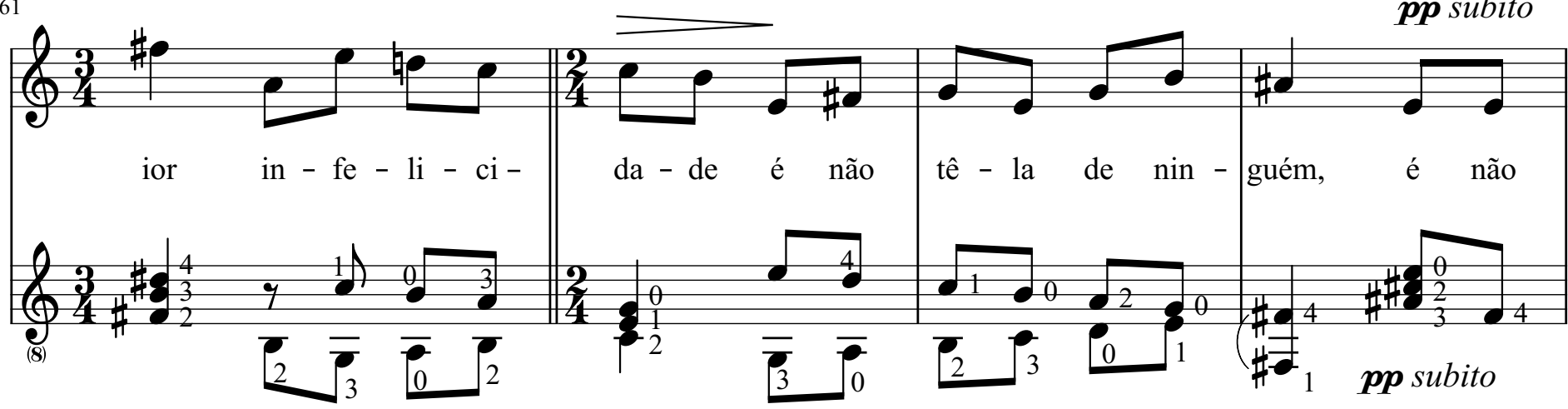



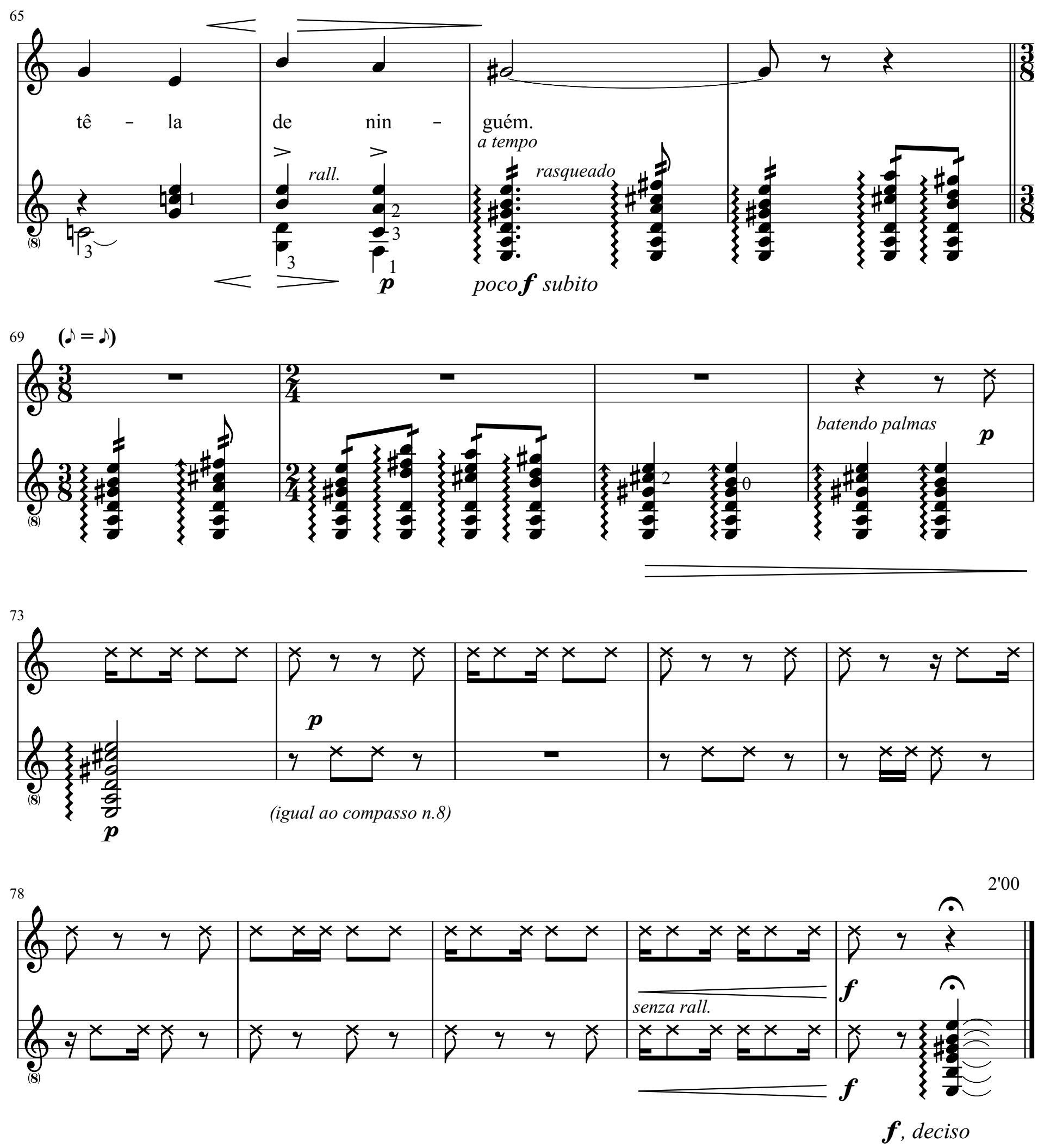

S. Paulo, outubro de 1968 (revisto em 1981) 


\section{FLAUTA E DOIS VIOLÕES}




\section{CANTILENA}

Versão para dois violões, edição e digitação:

Lucas Vieira e Edelton Gloeden
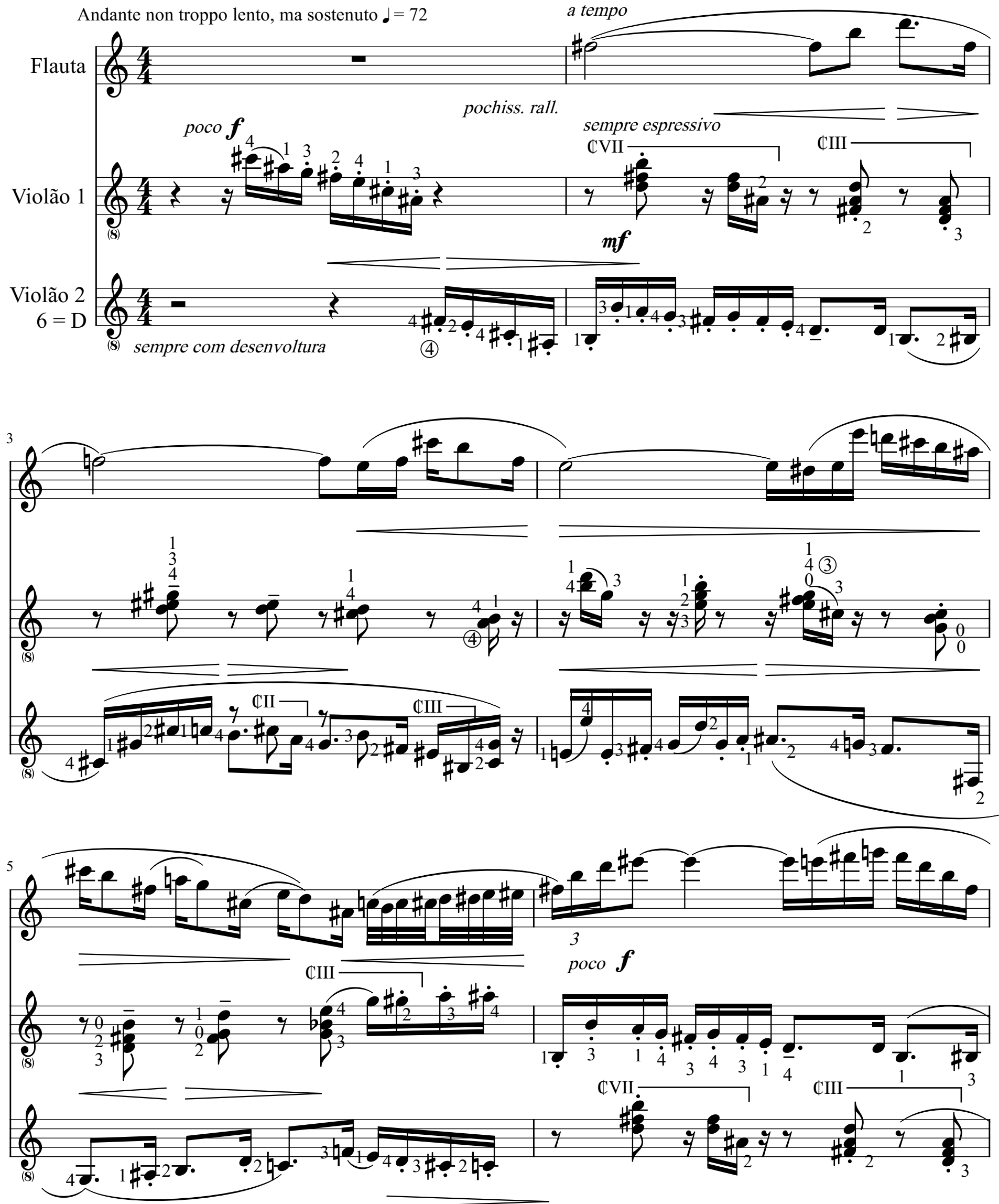

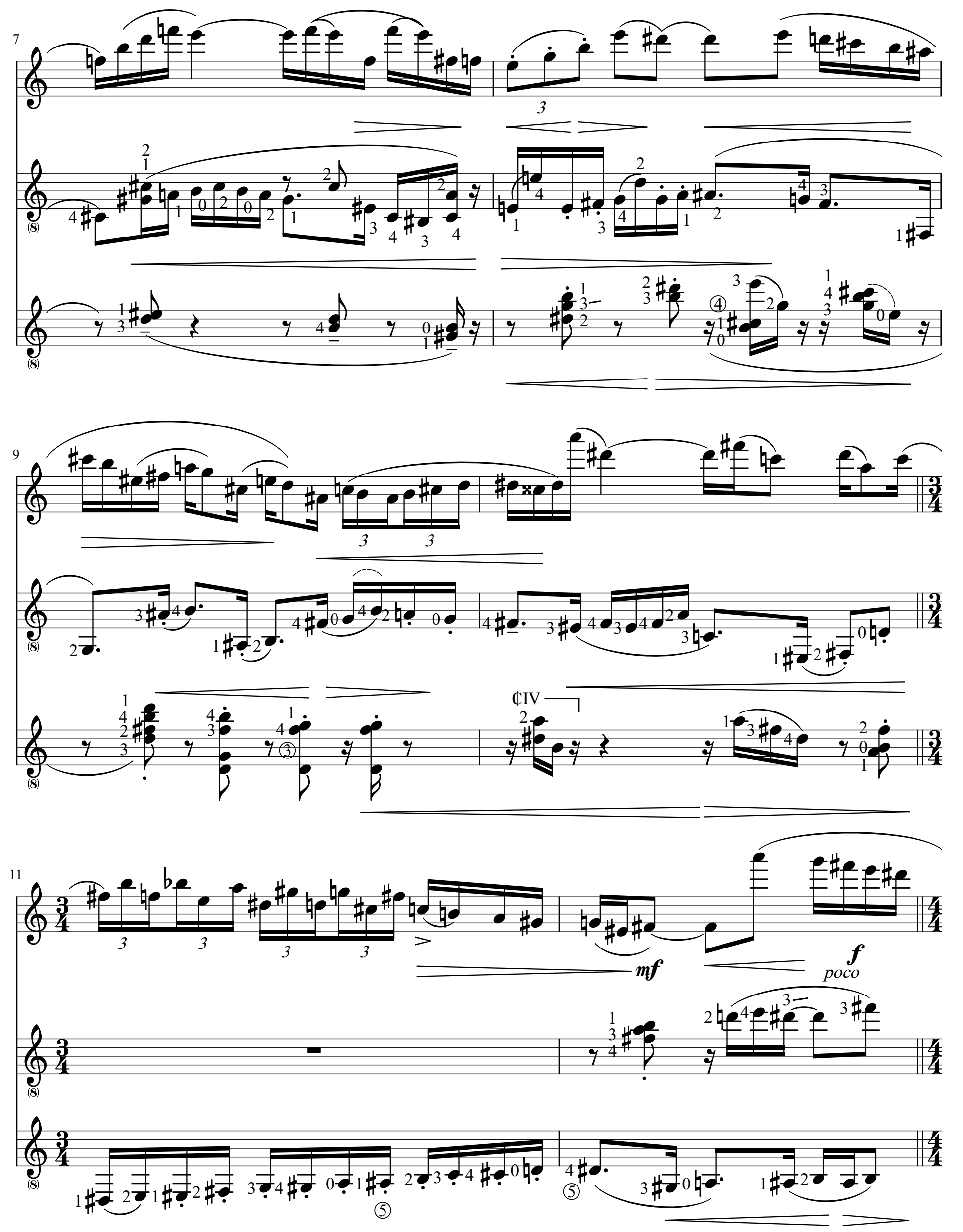


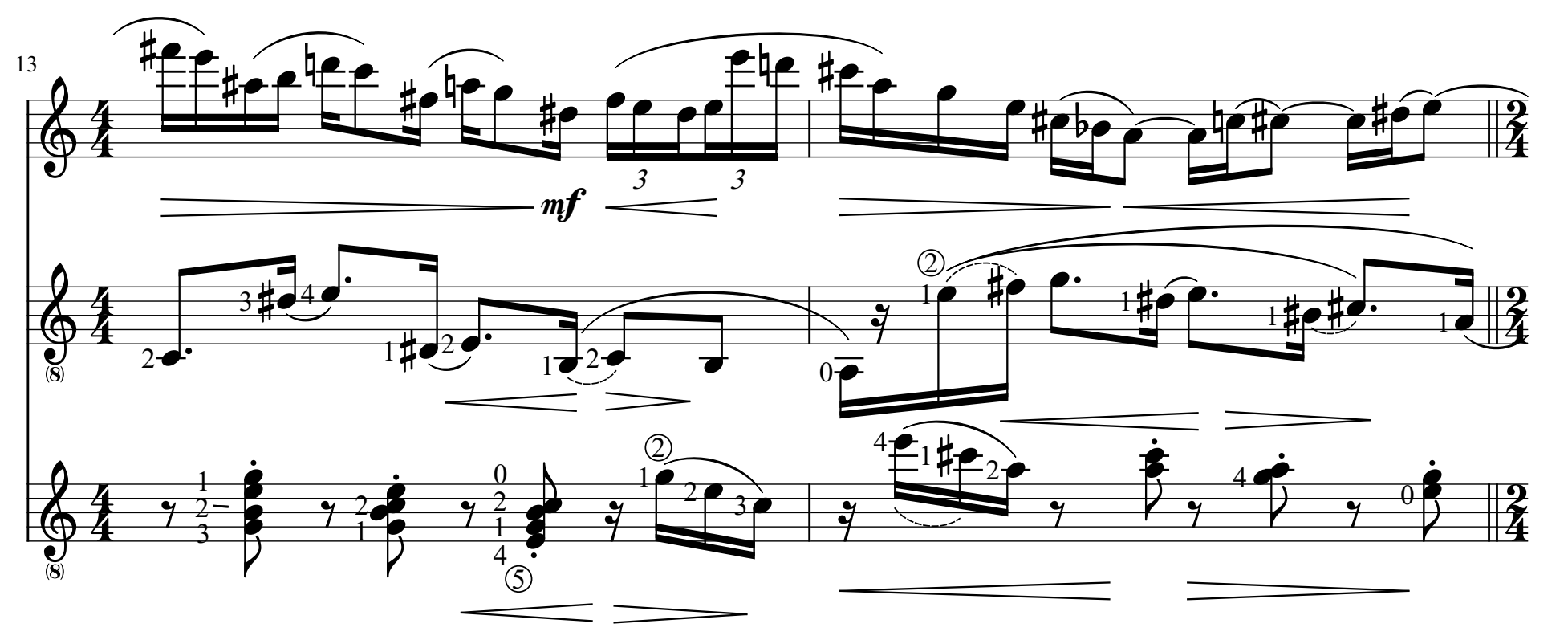

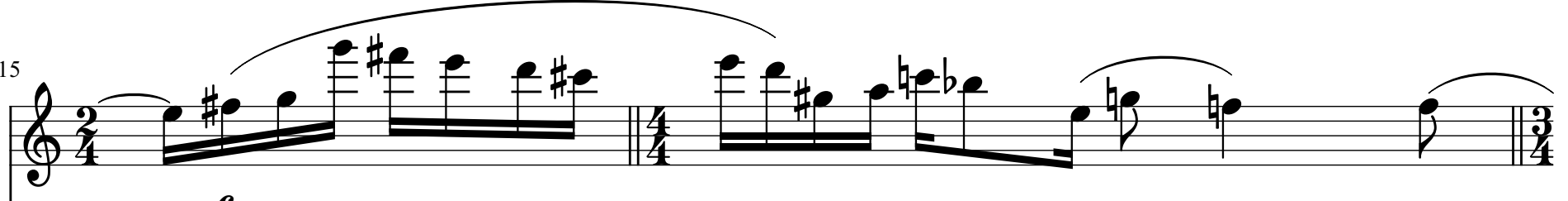

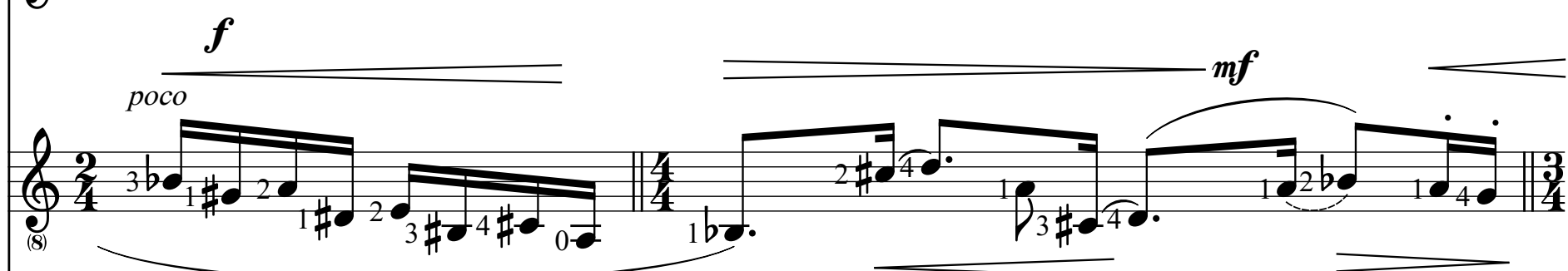
6\%, ?

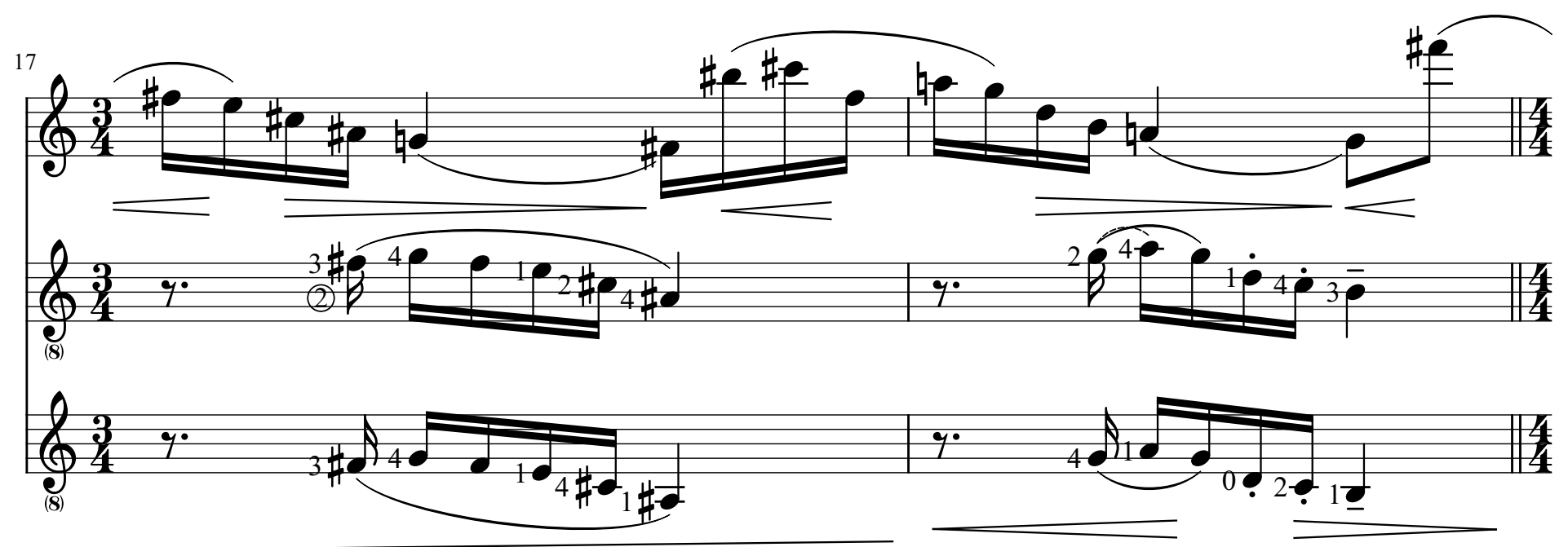




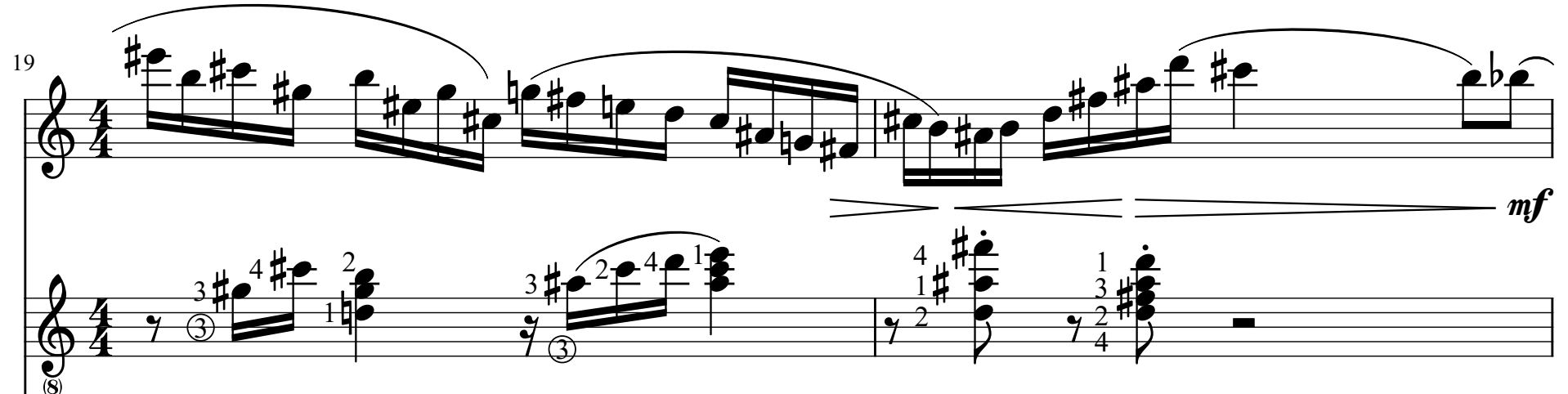

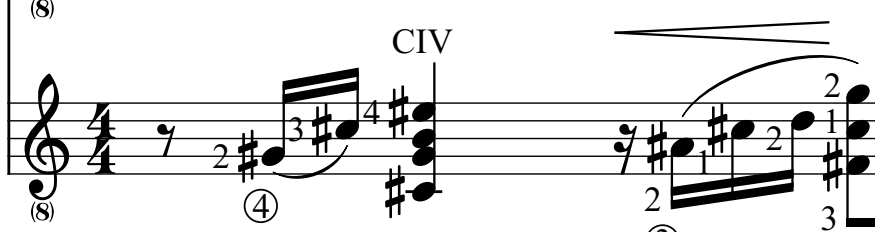

(3)

drounmonsm

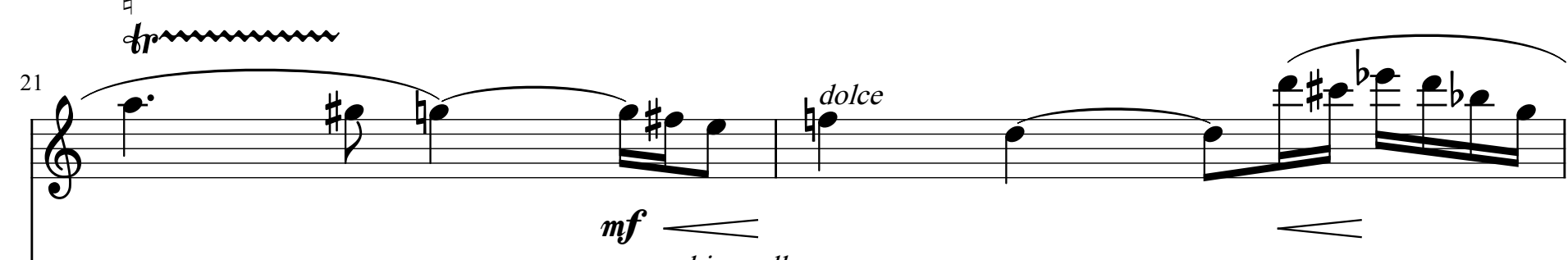

$\bigotimes_{(8)}$ $\int_{(8)} 424 f_{10}$

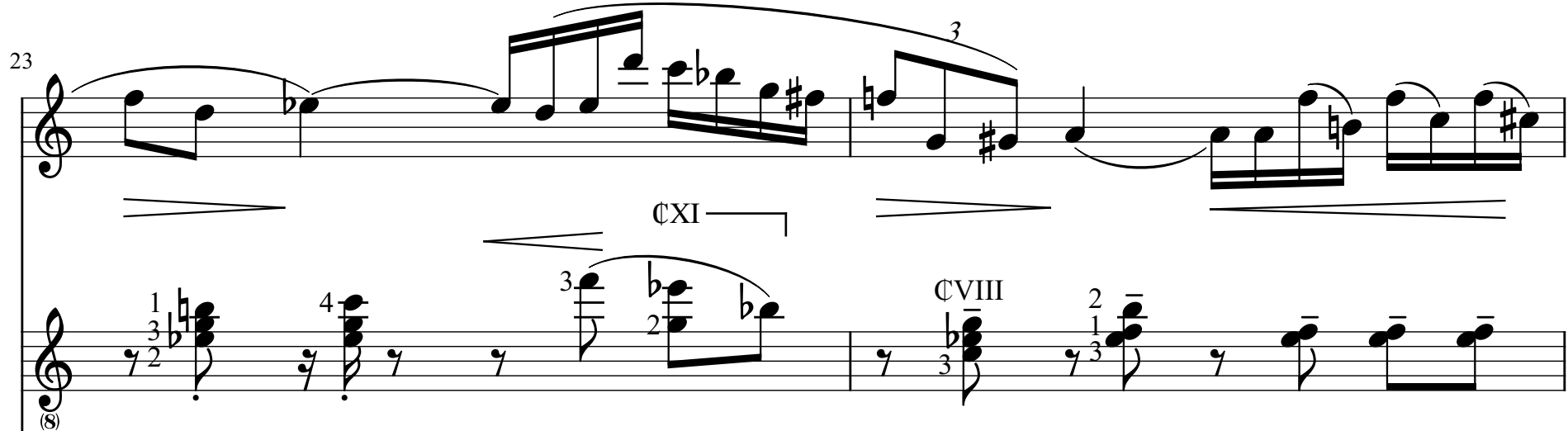

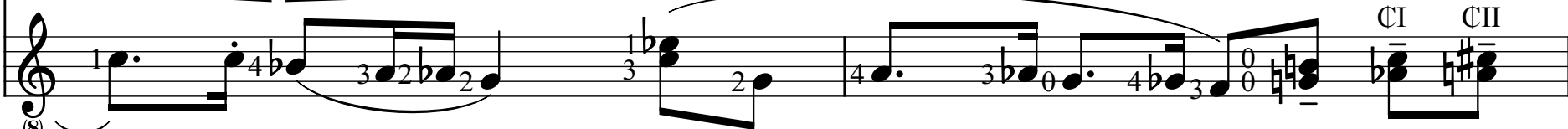




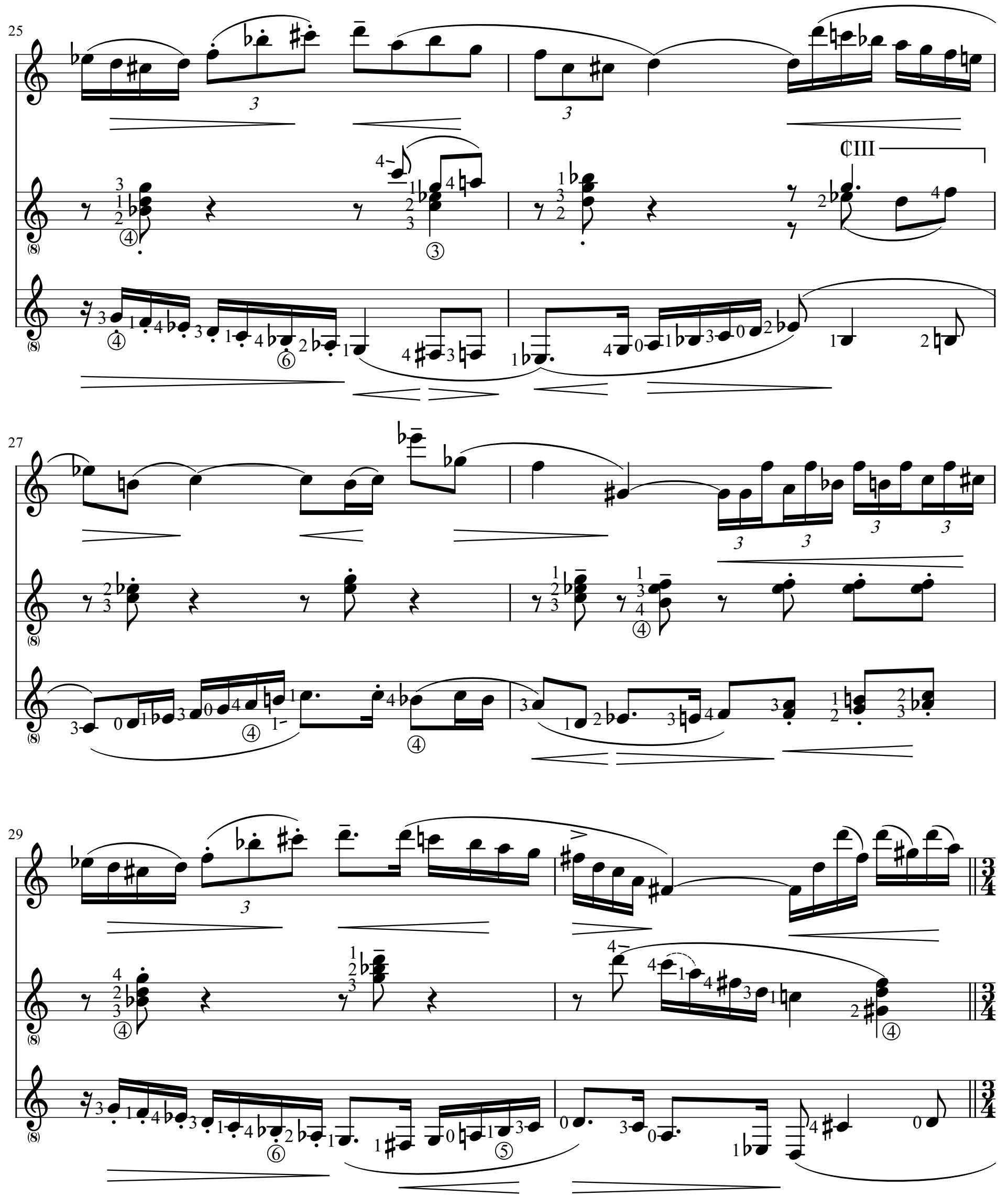



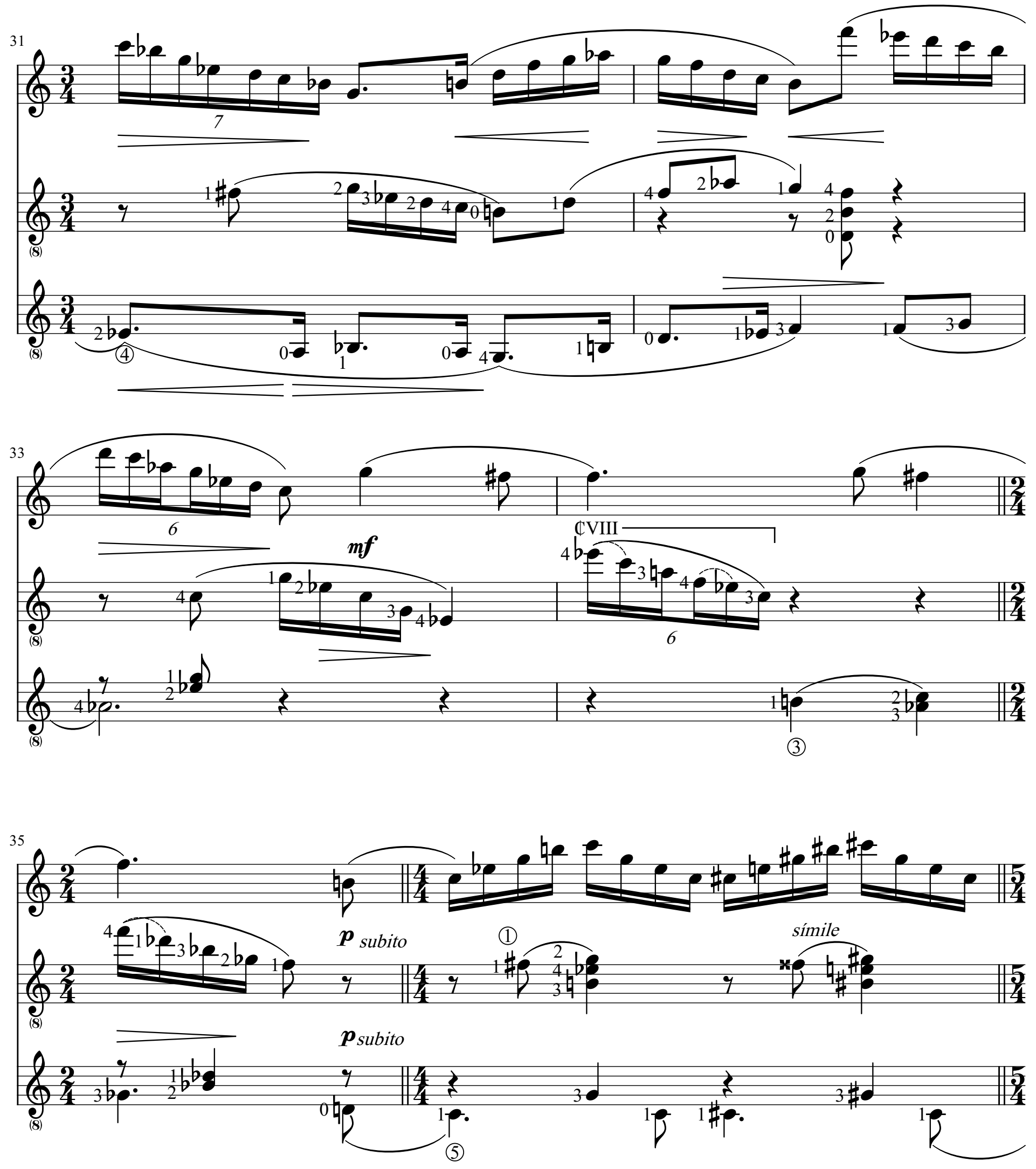

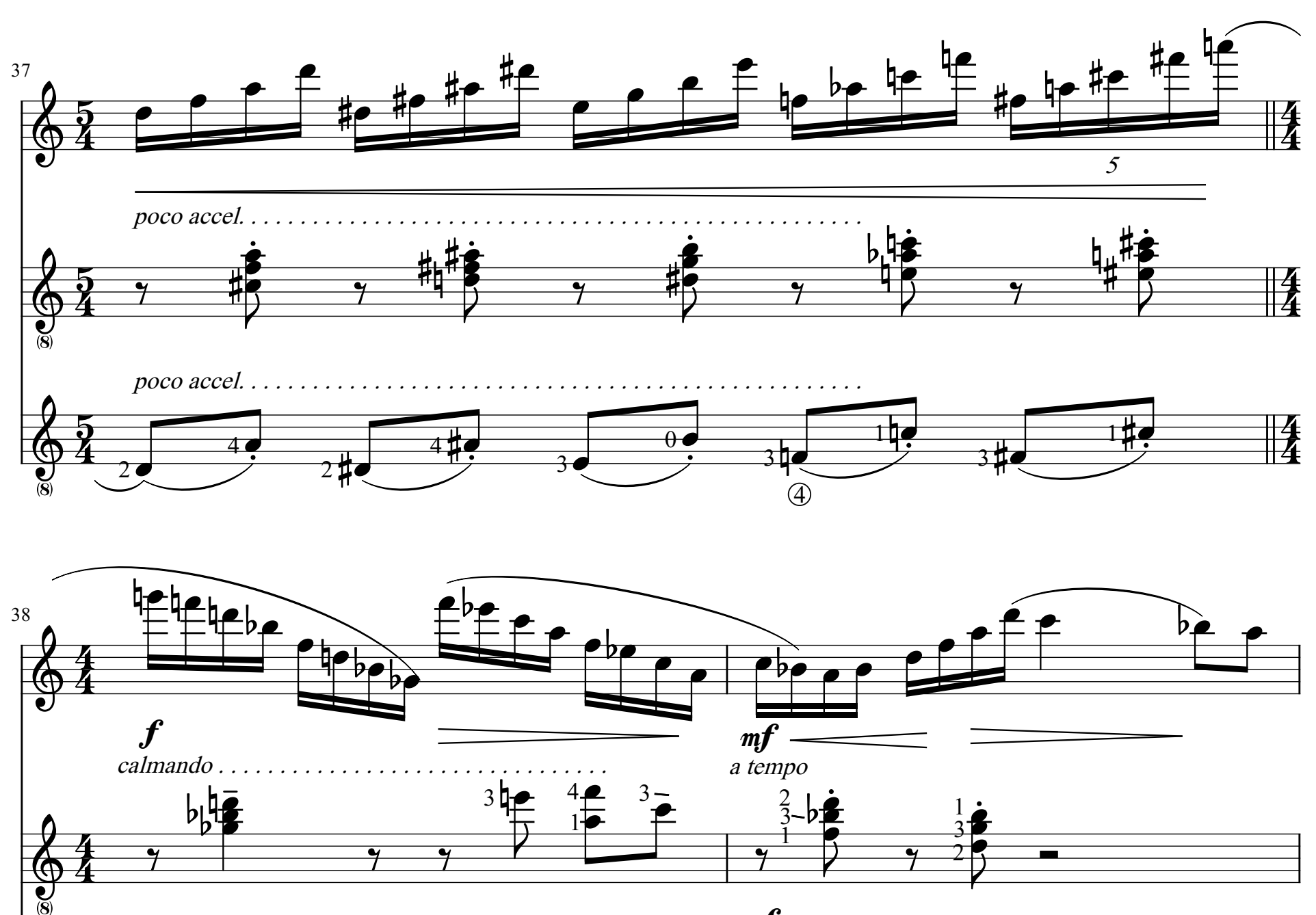

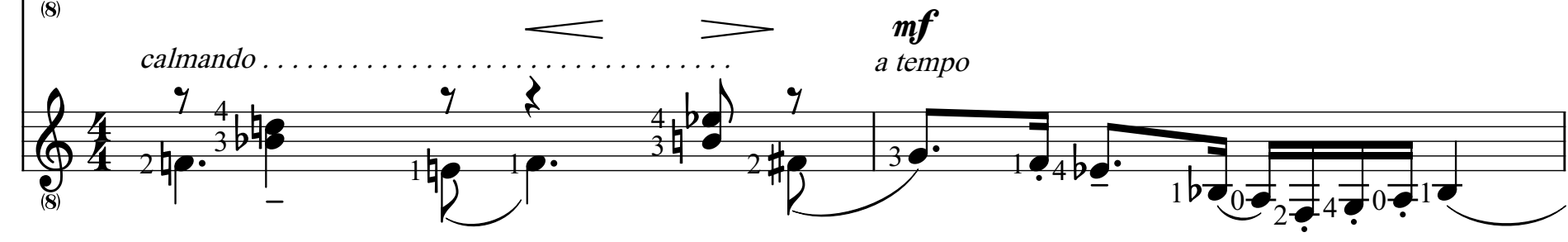

dpronsmonsmons

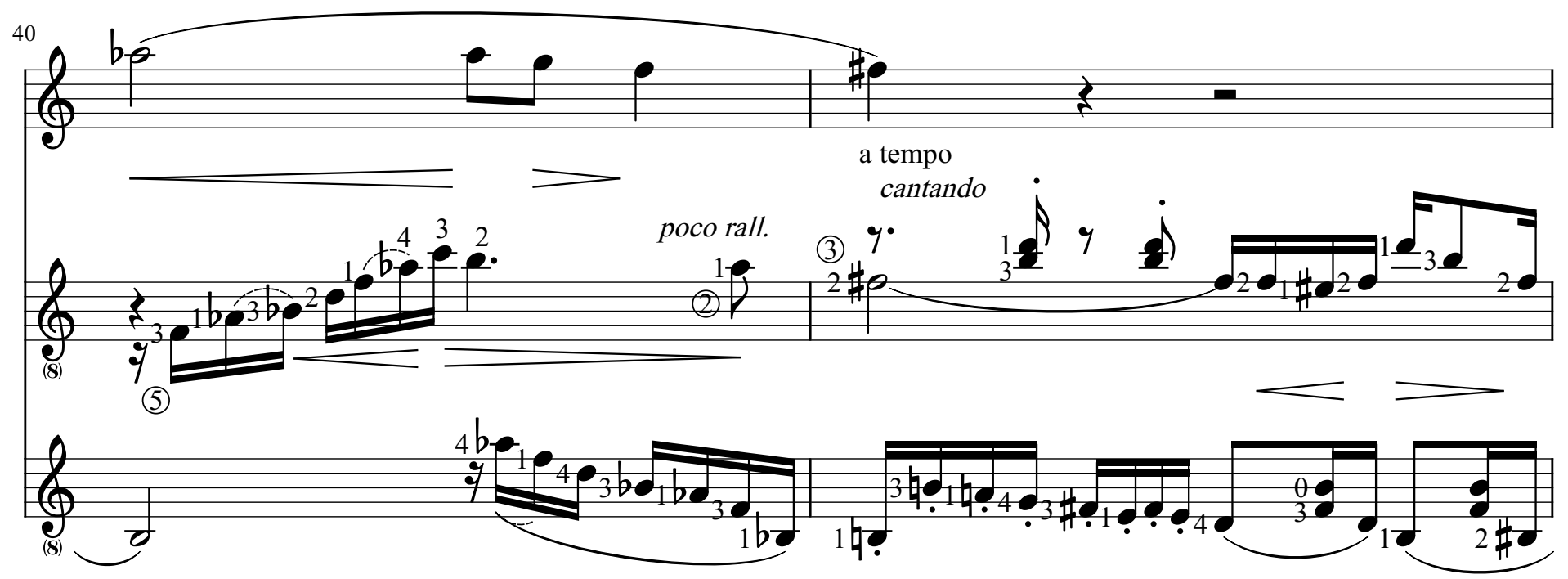


$£$

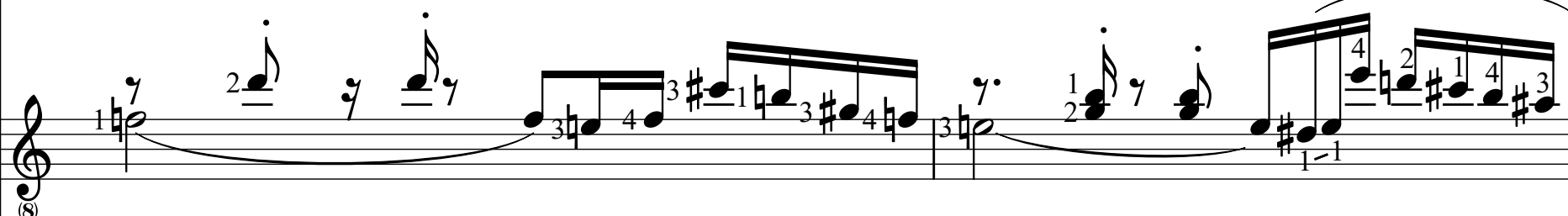

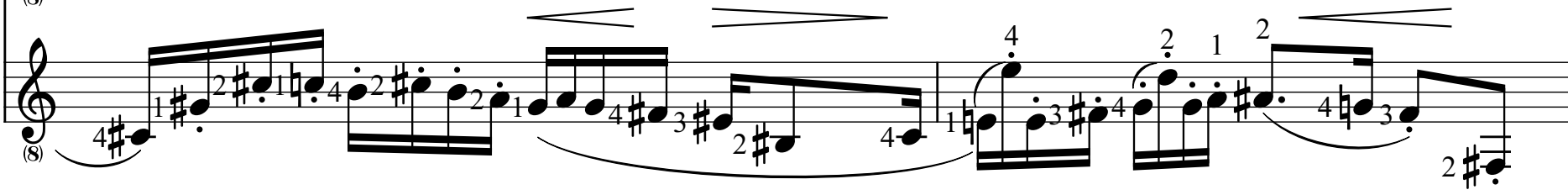

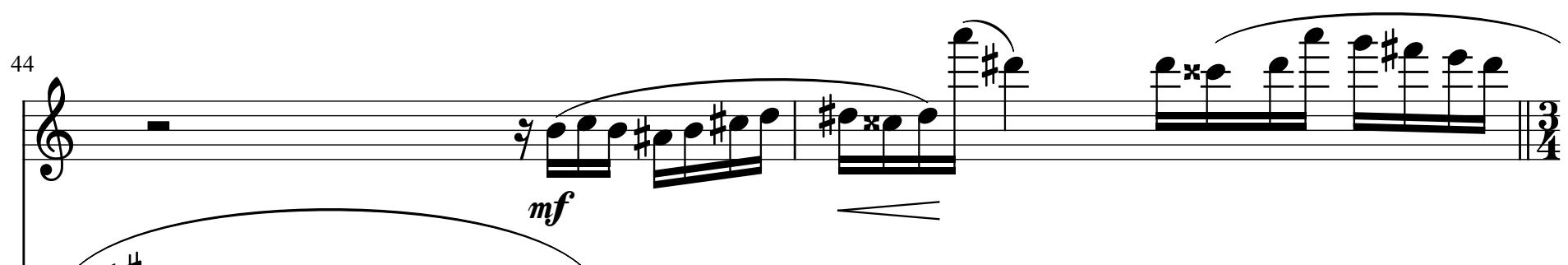

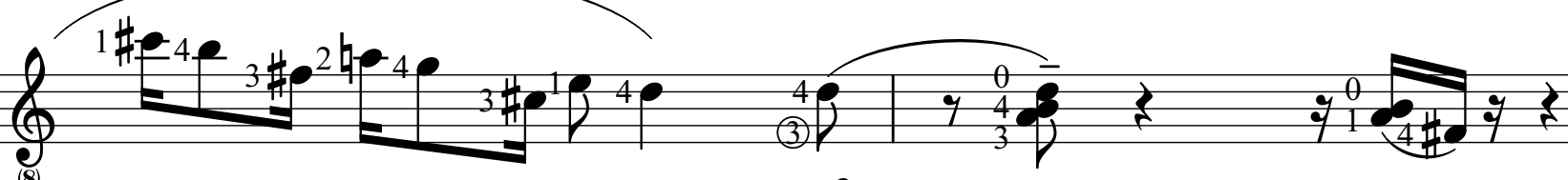

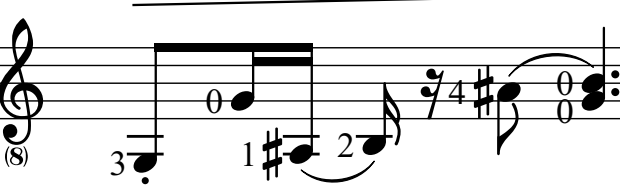

$\boldsymbol{m} \boldsymbol{f}$

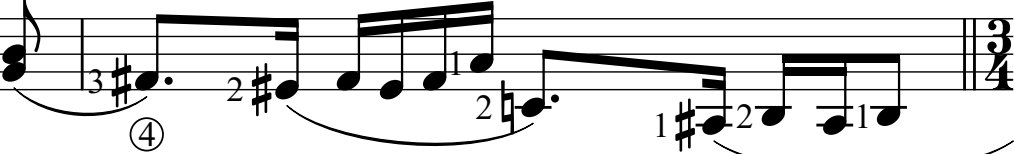



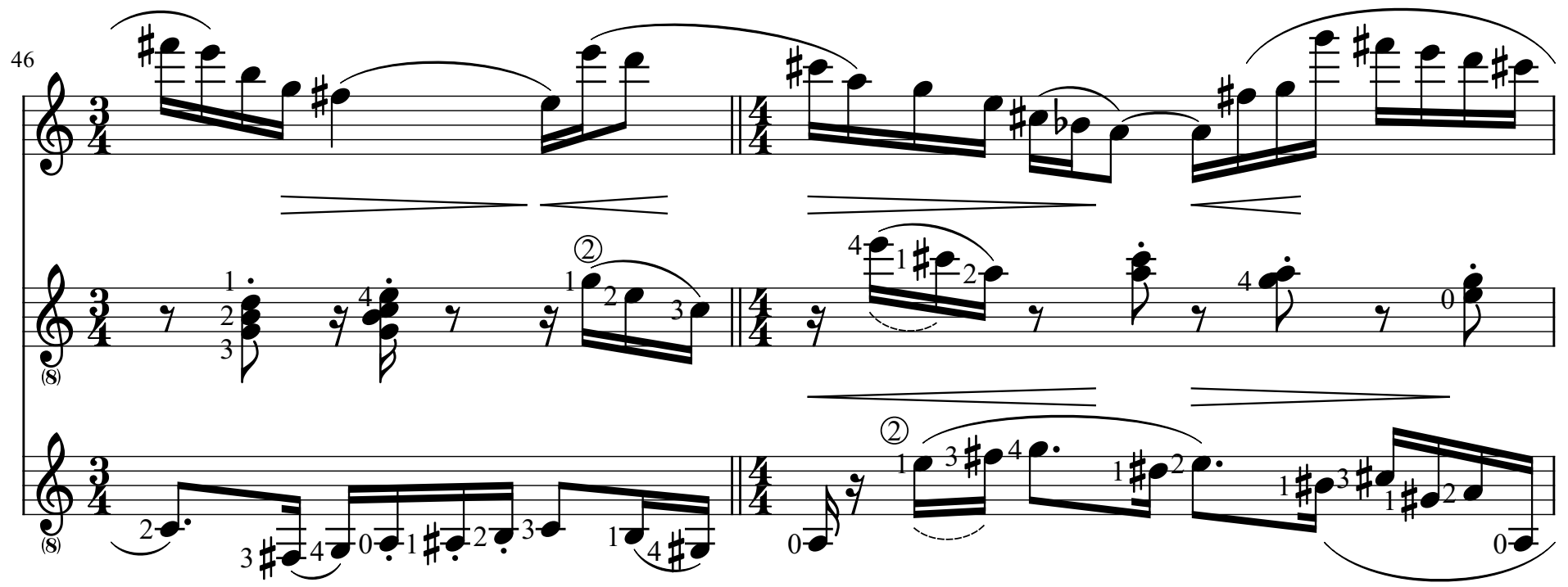



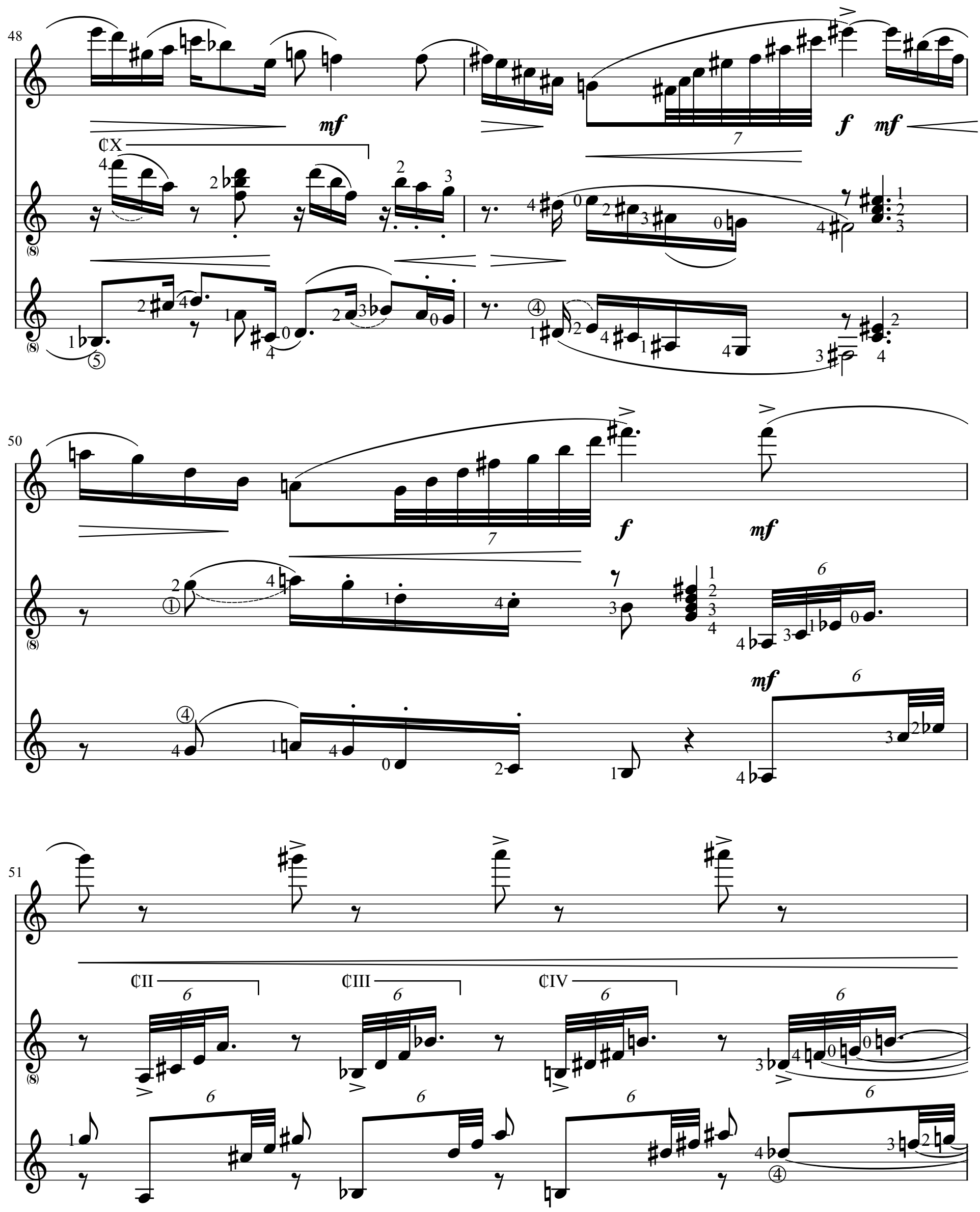

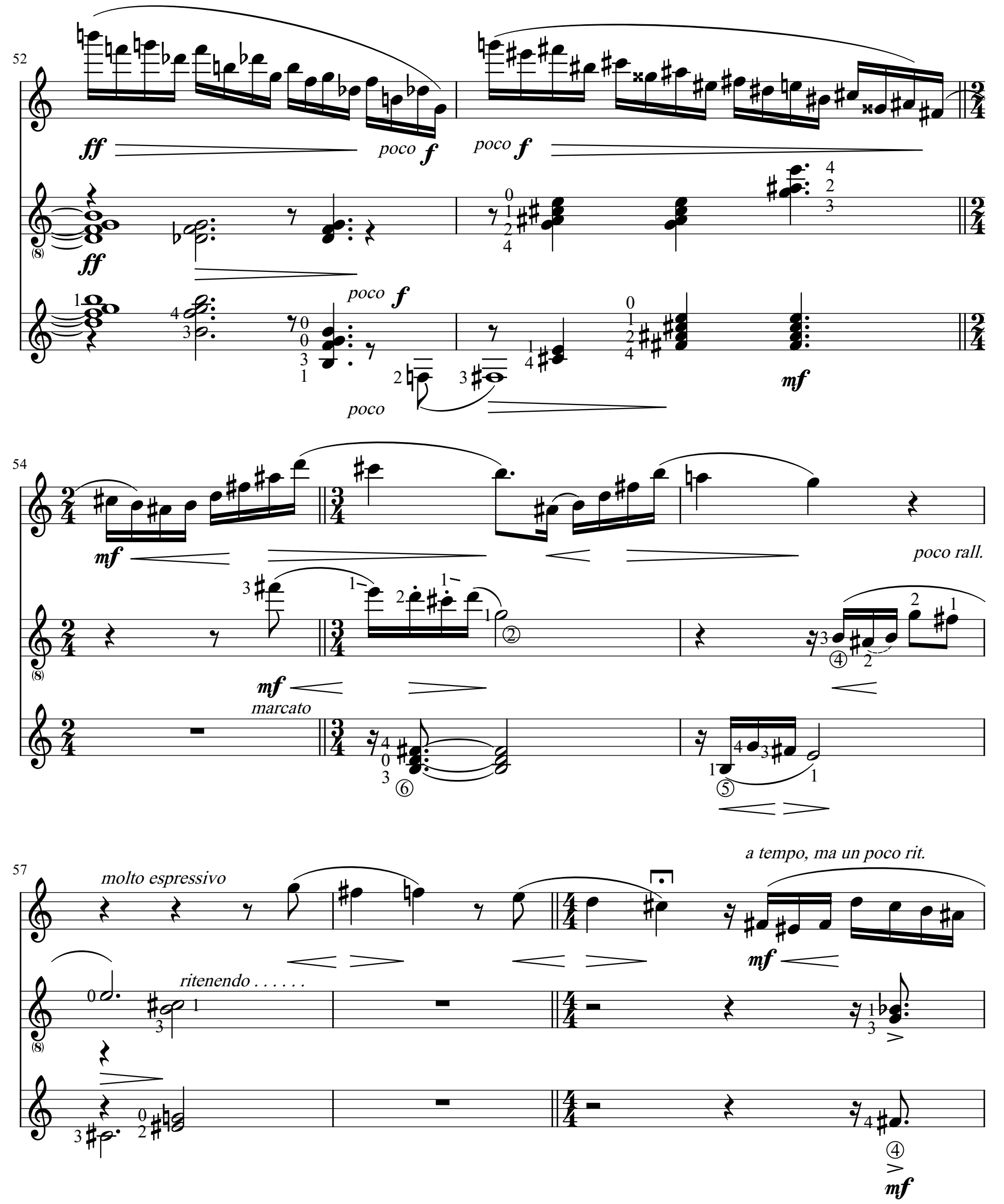


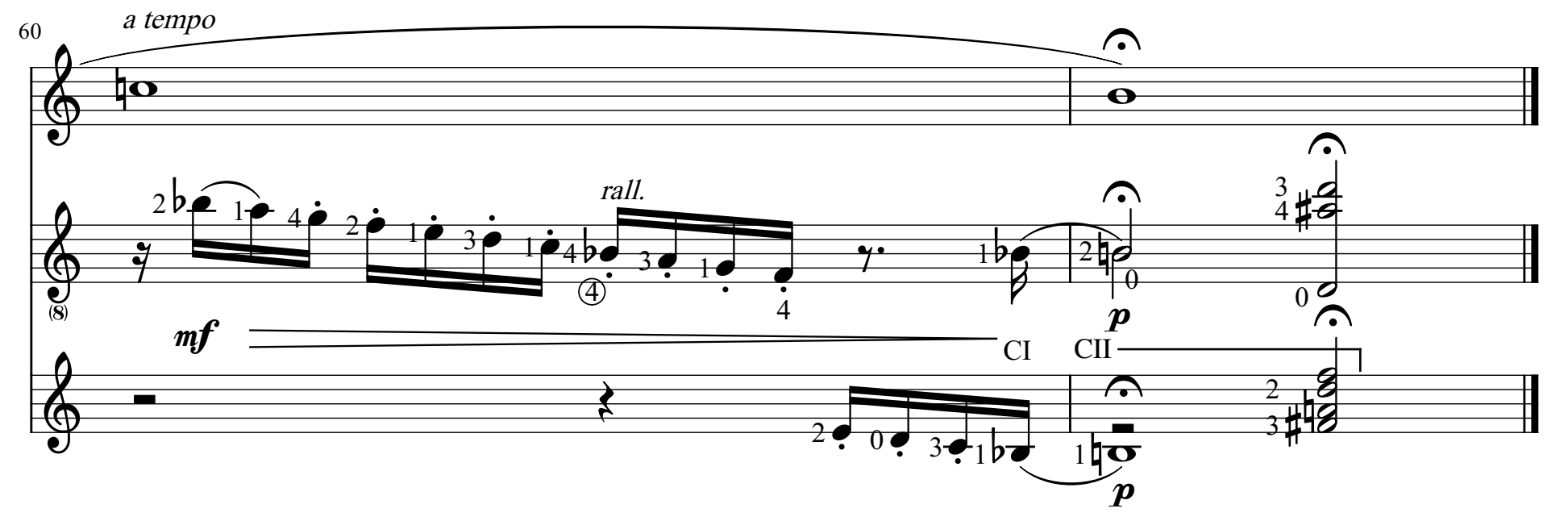




\section{POEMETO}

Versão para dois violões, edição e digitação:

Lucas Vieira e Edelton Gloeden
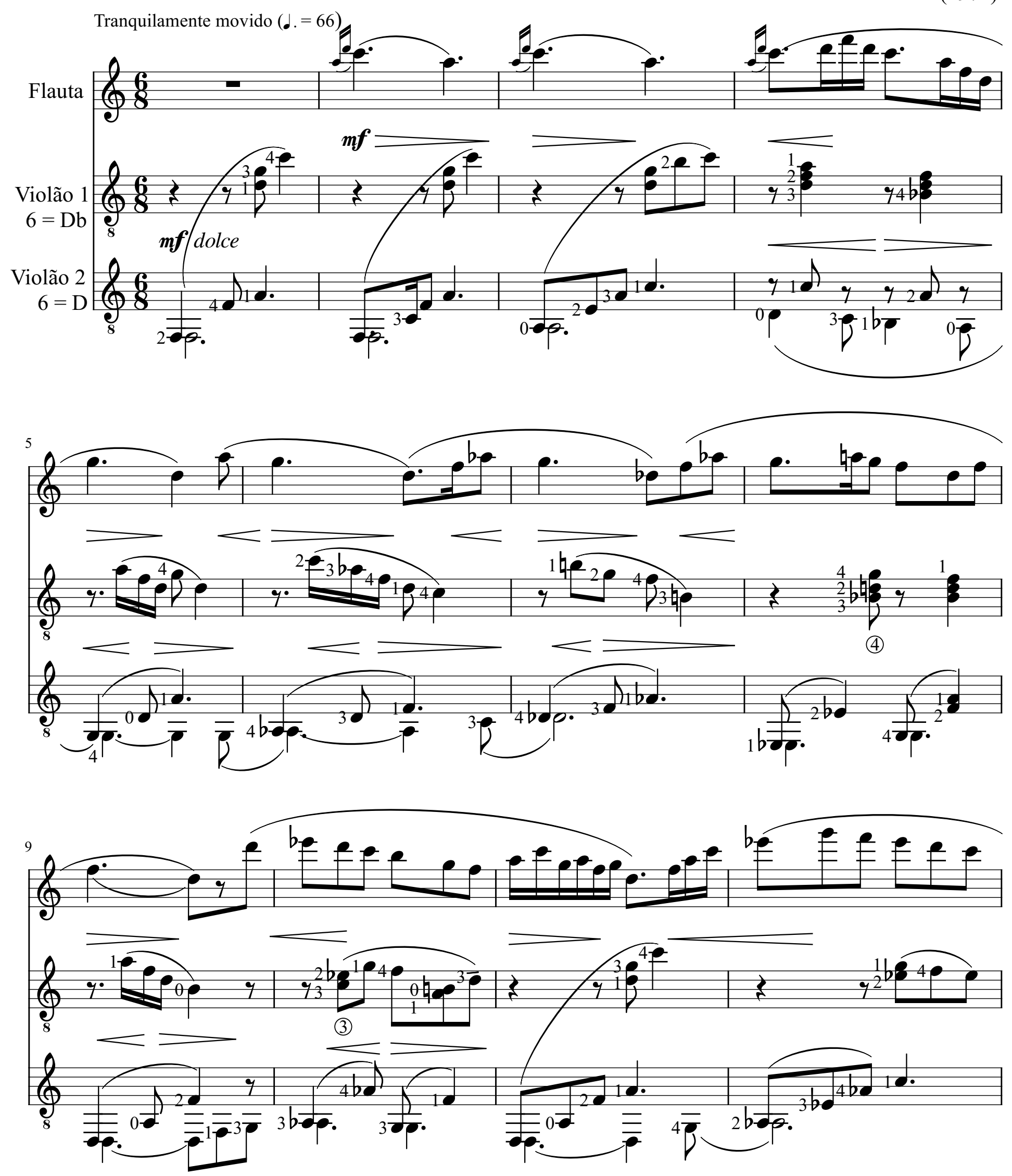


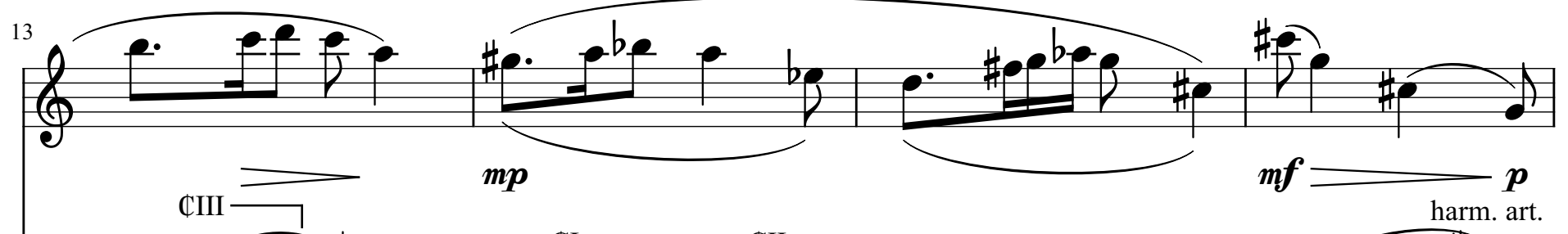

$(8$ $\bigotimes_{8}$
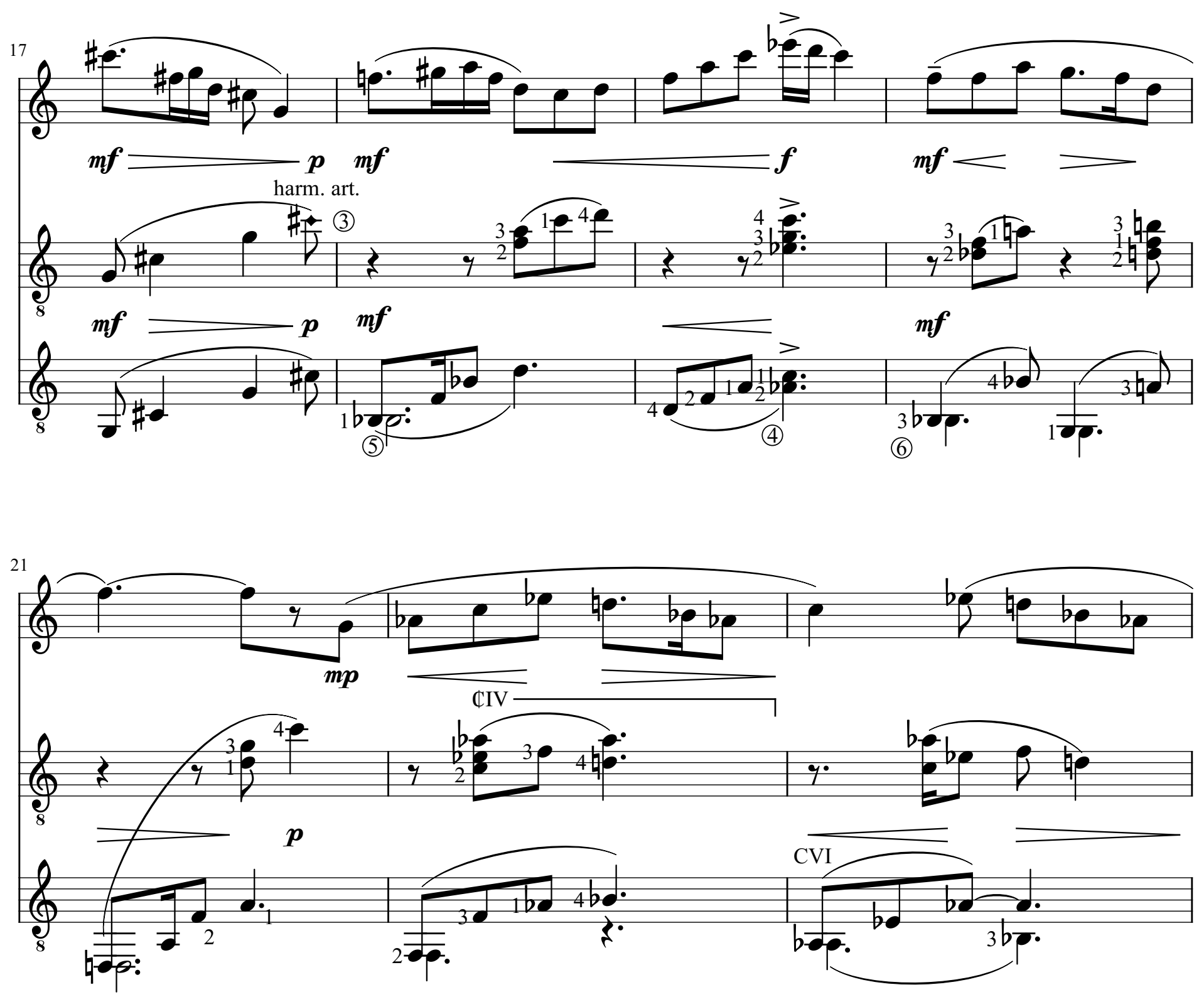

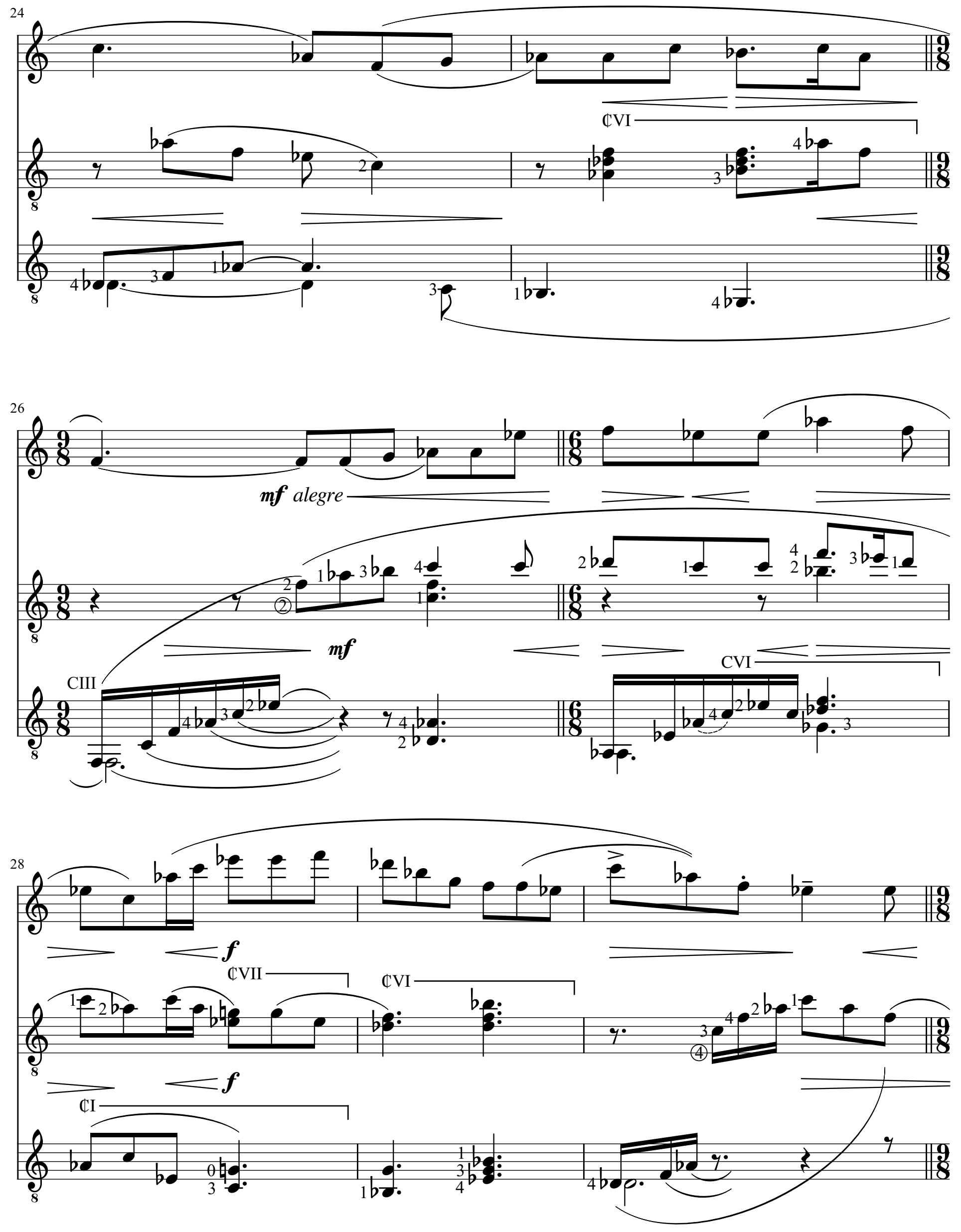

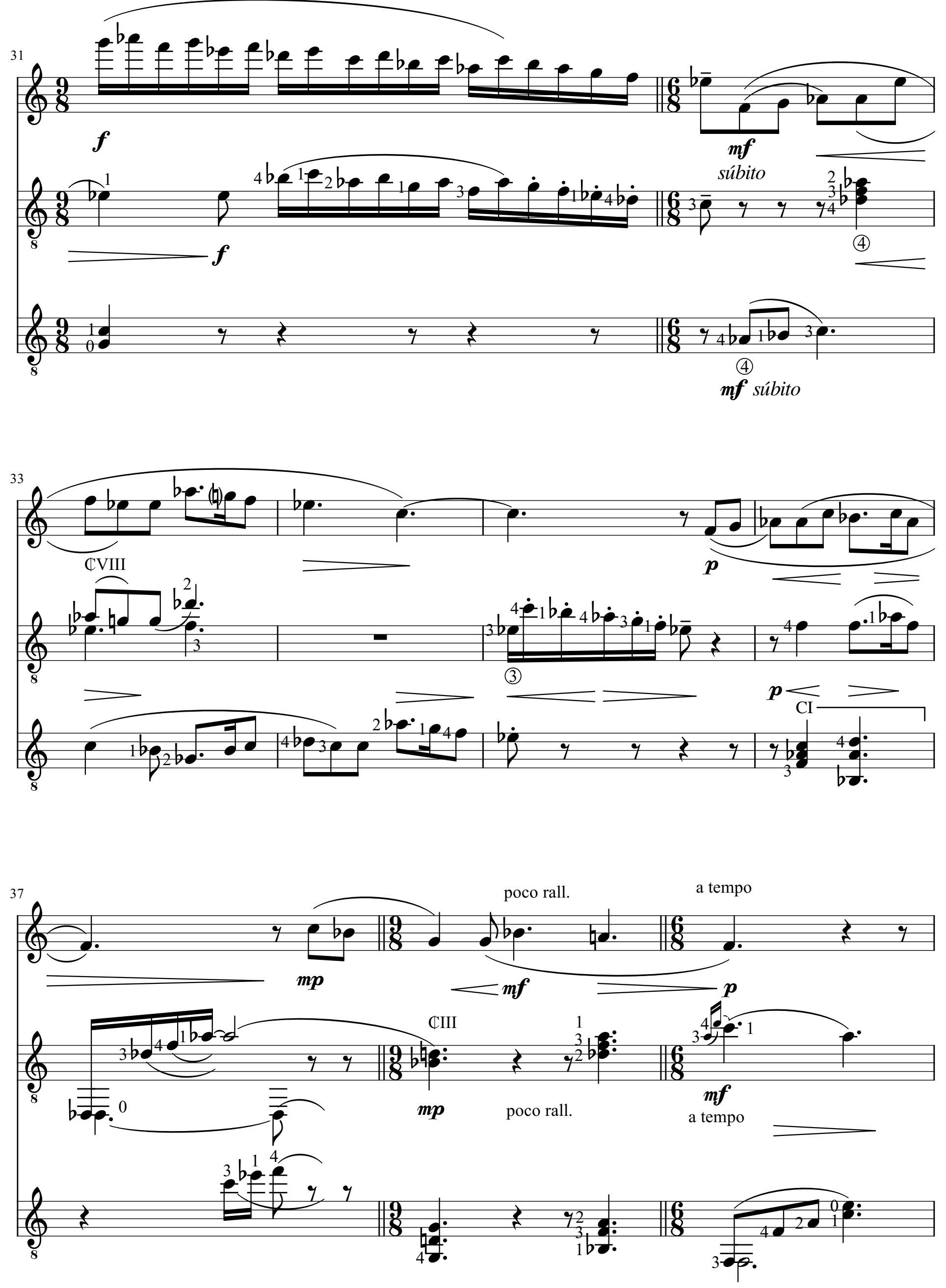

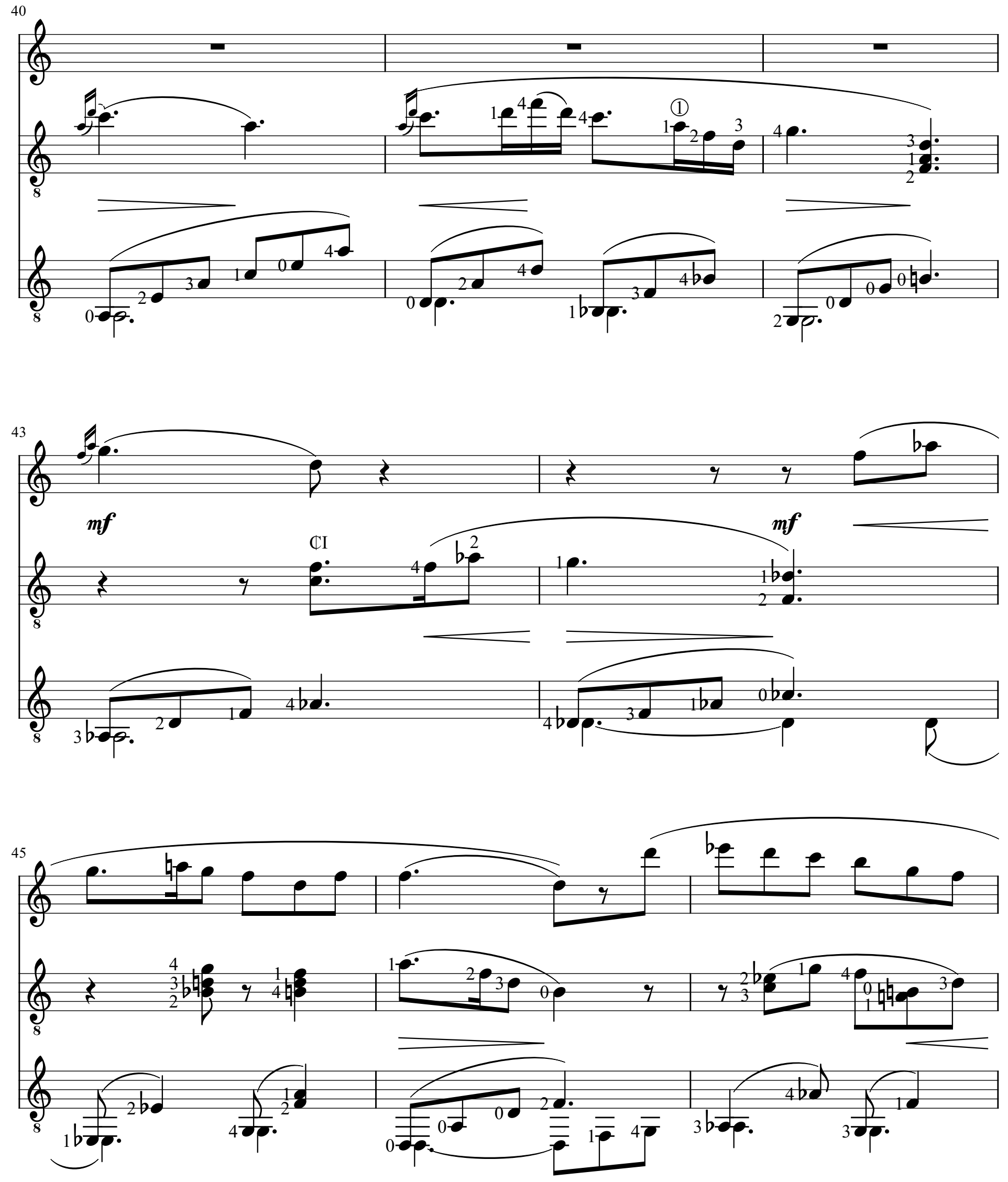

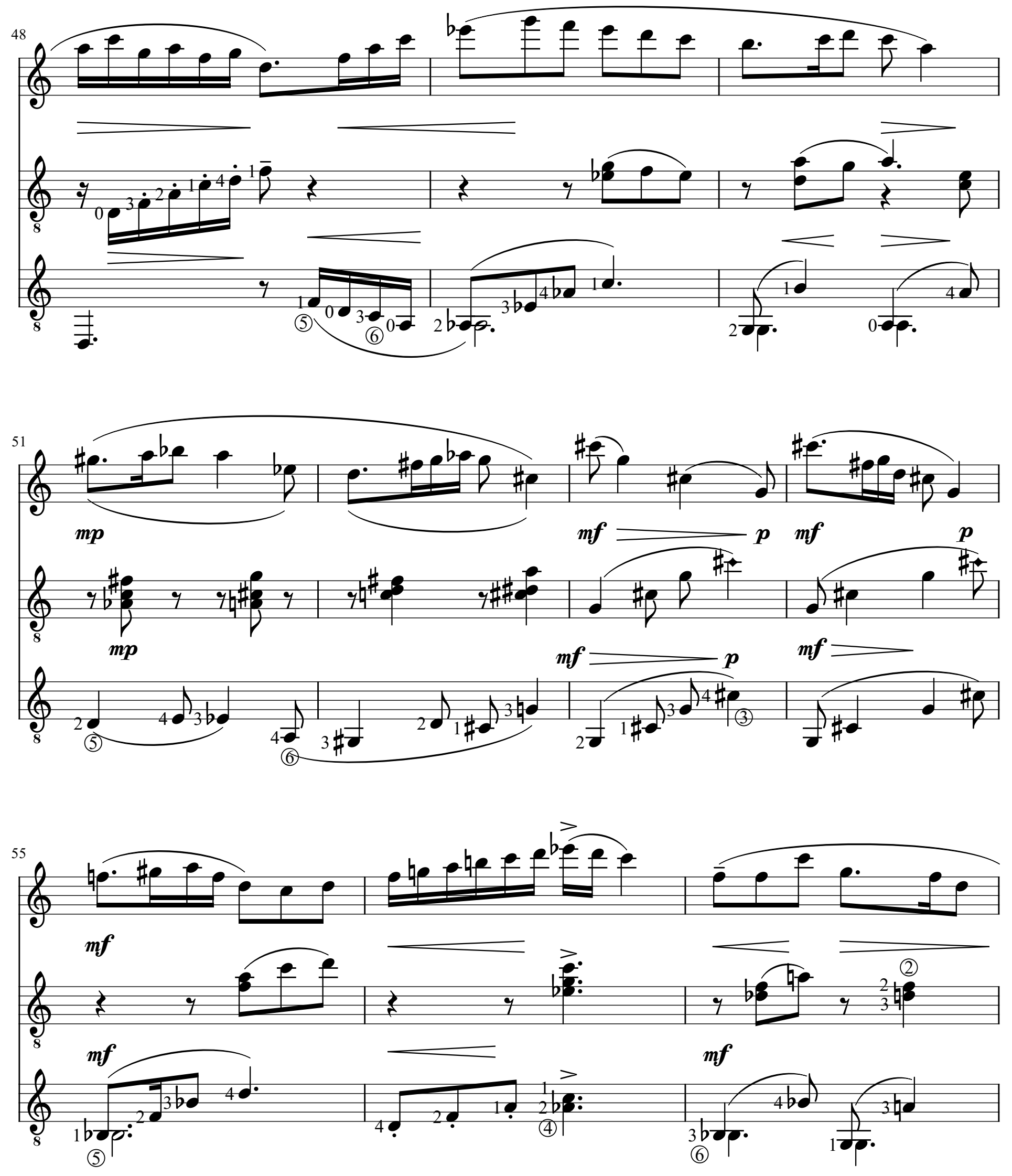




\section{TOCCATINA}

Versão para dois violões, edição e digitação:

Lucas Vieira e Edelton Gloeden

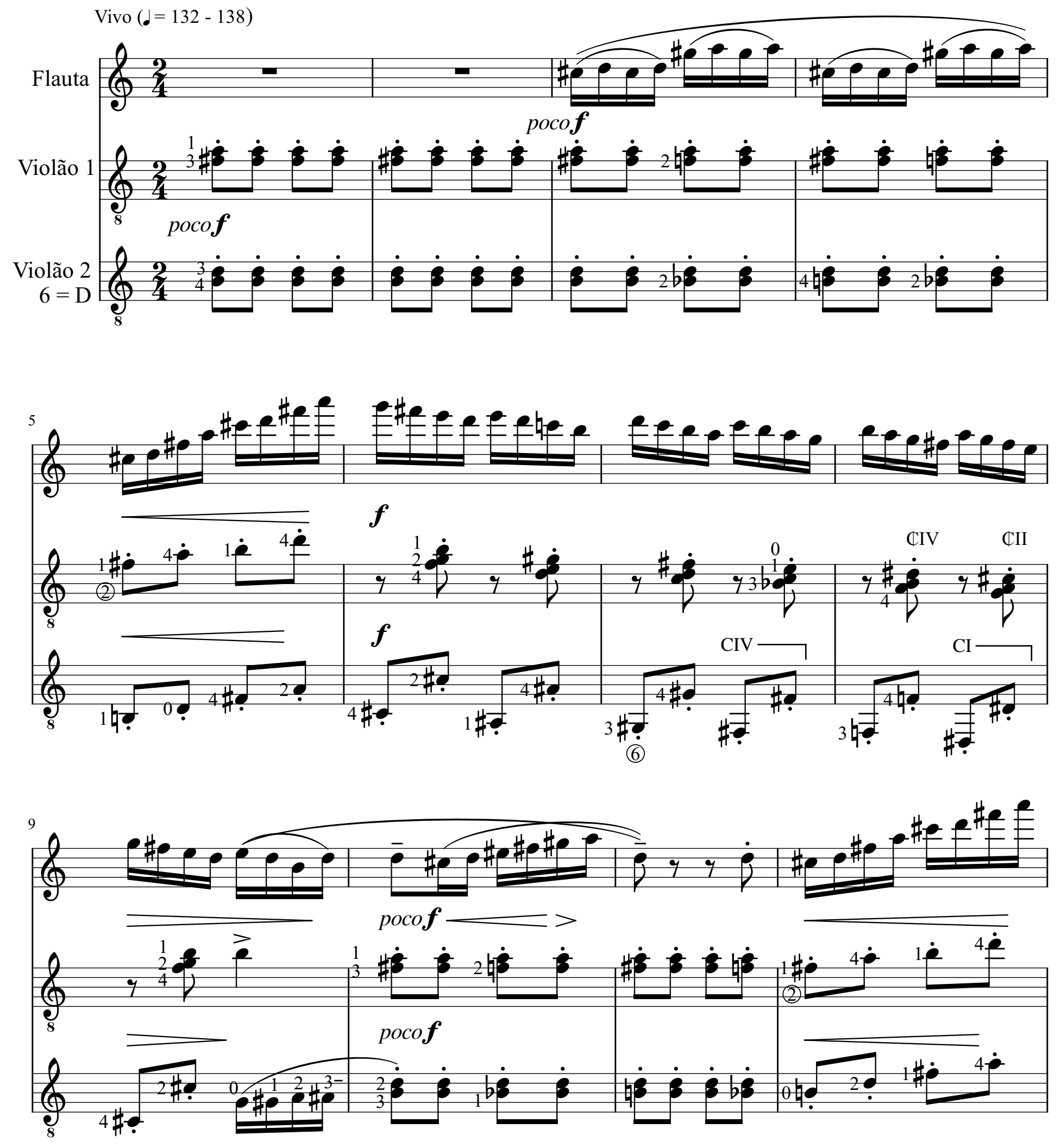



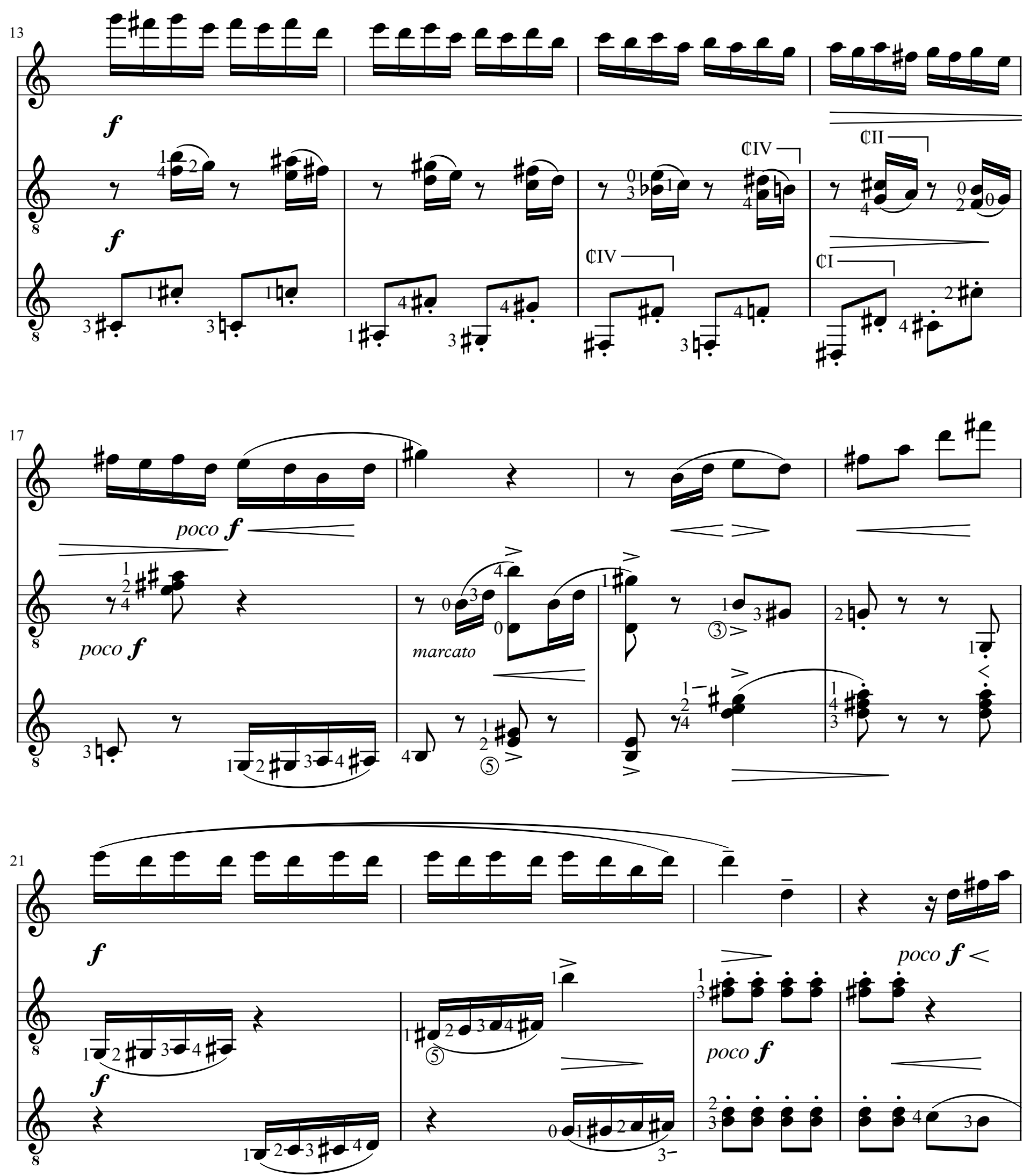

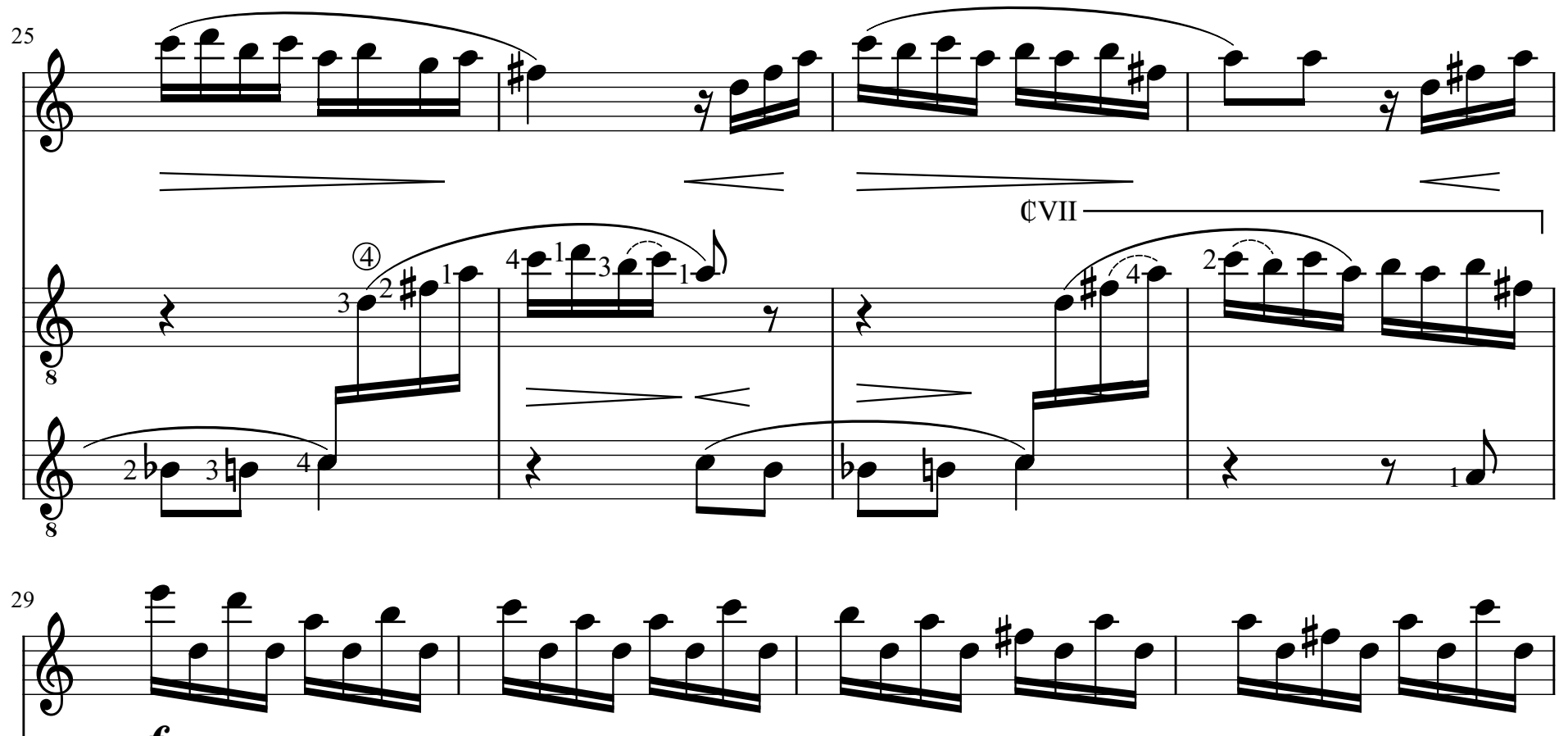

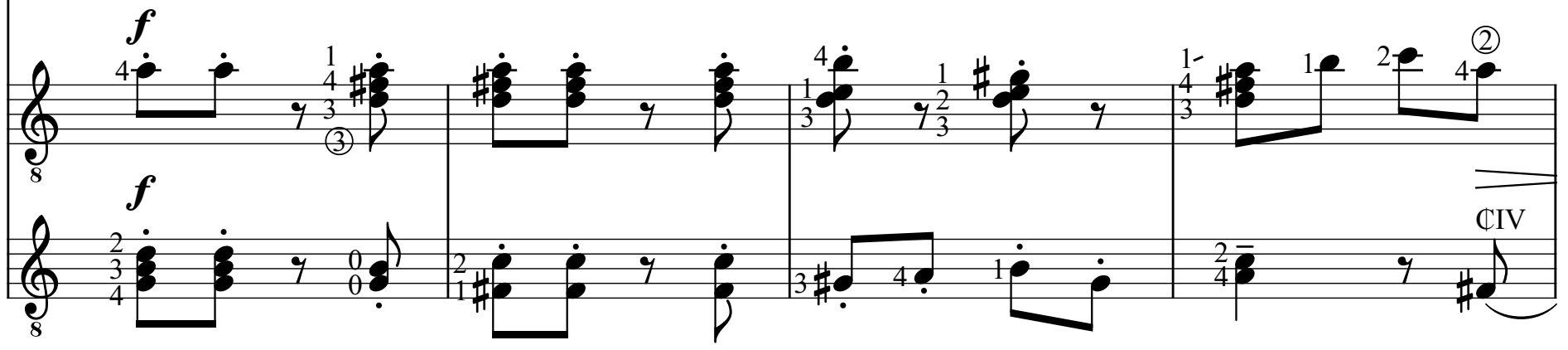

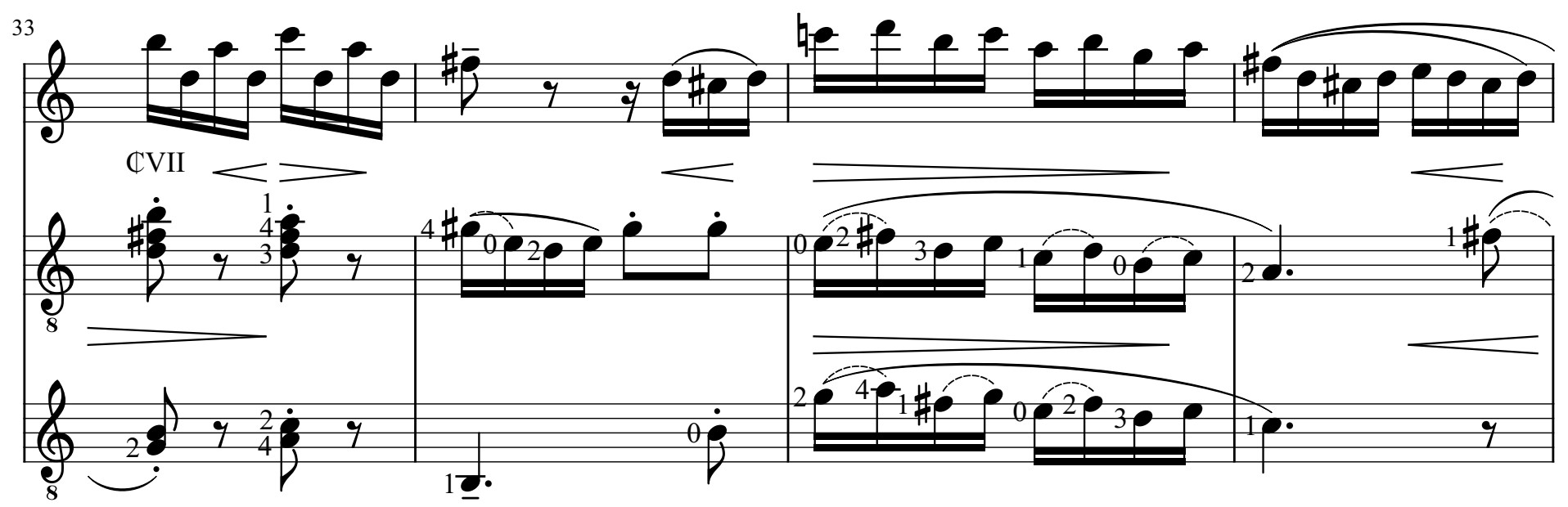

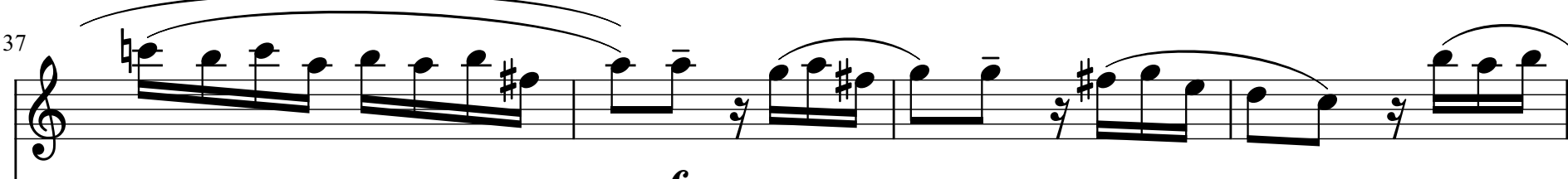

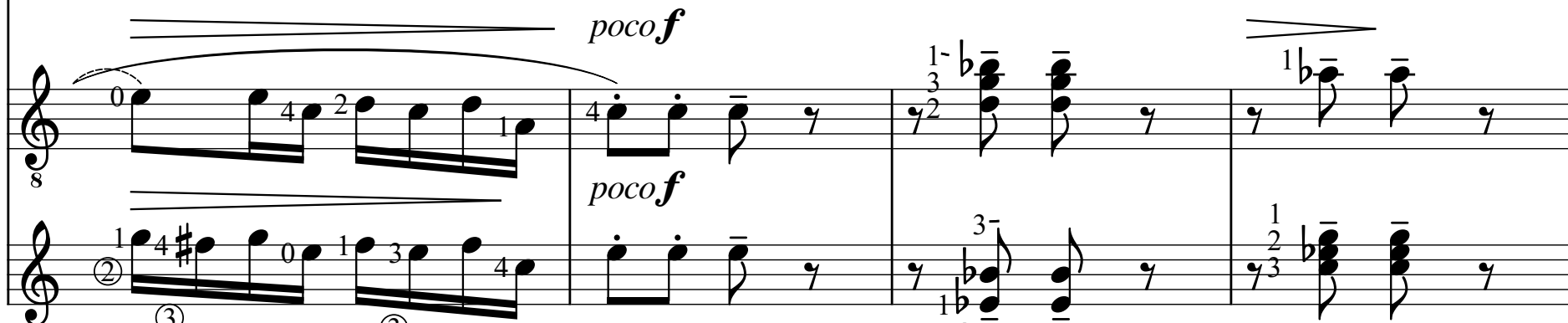

(3)

(3)

(4) 

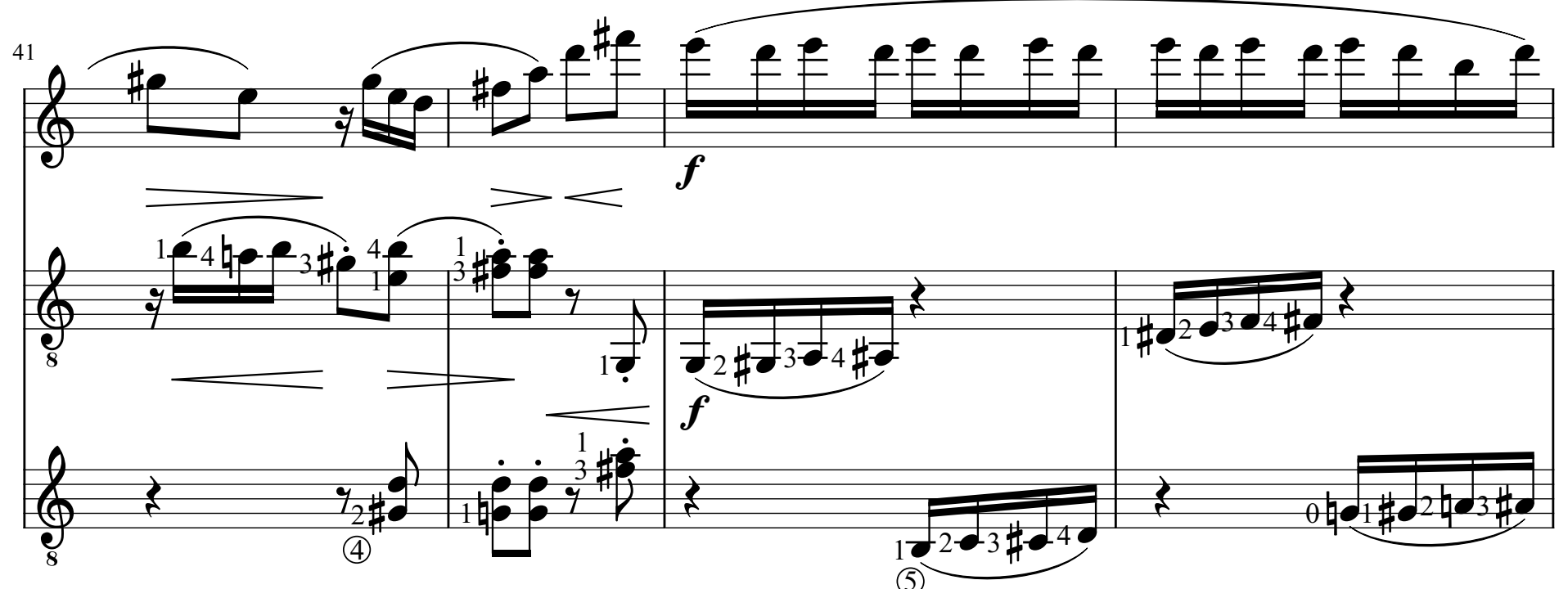

(5)
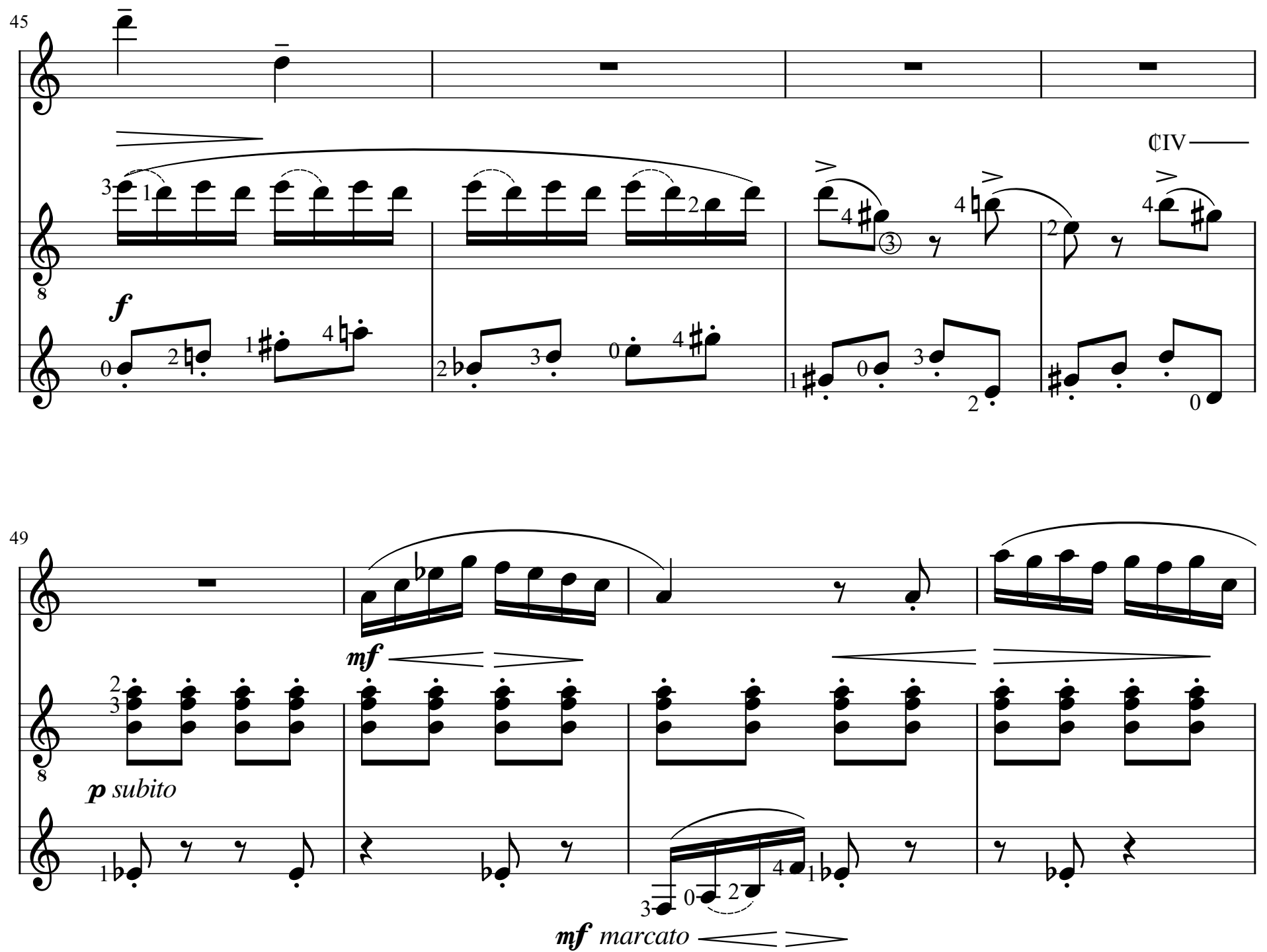


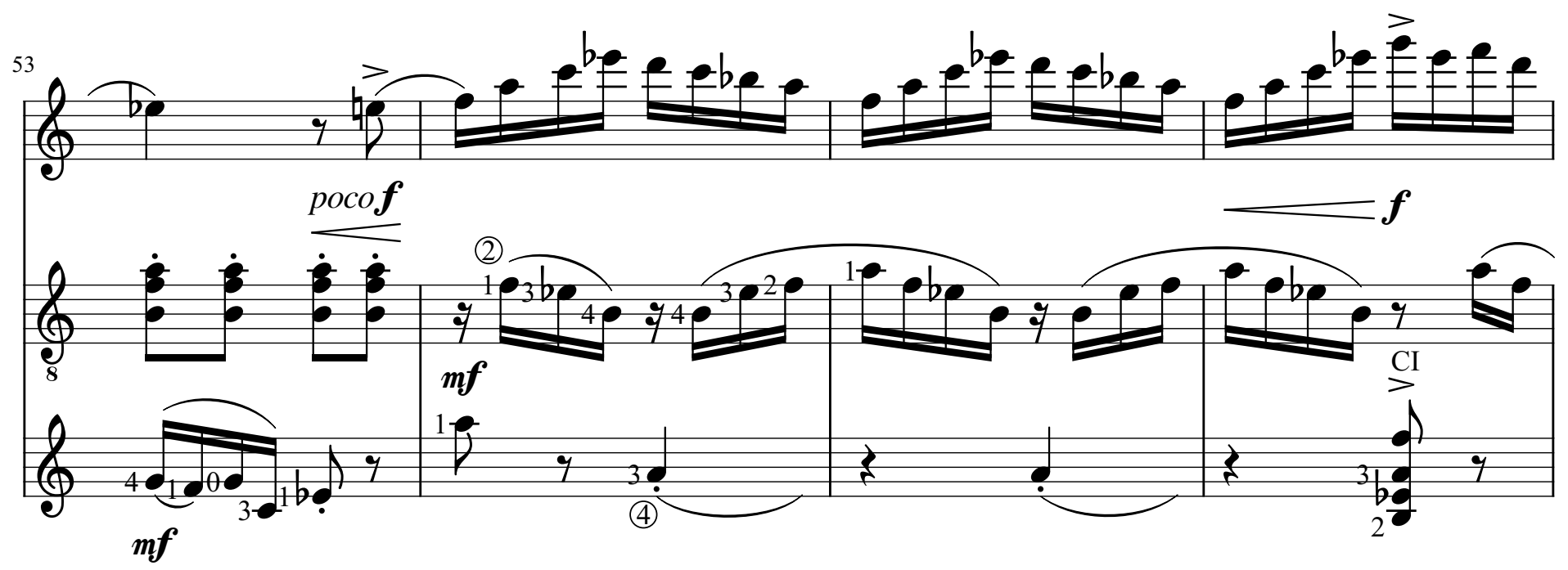

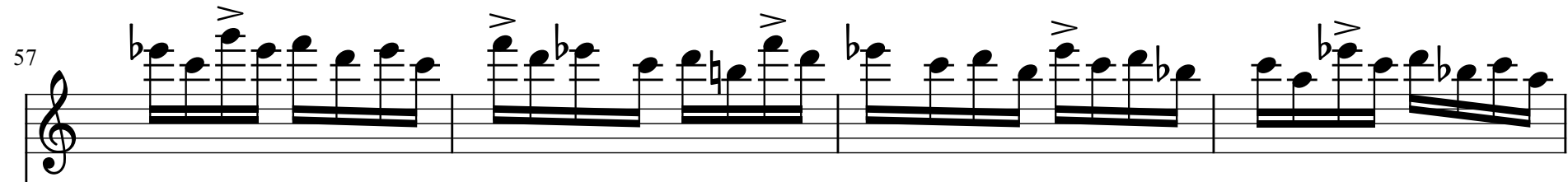
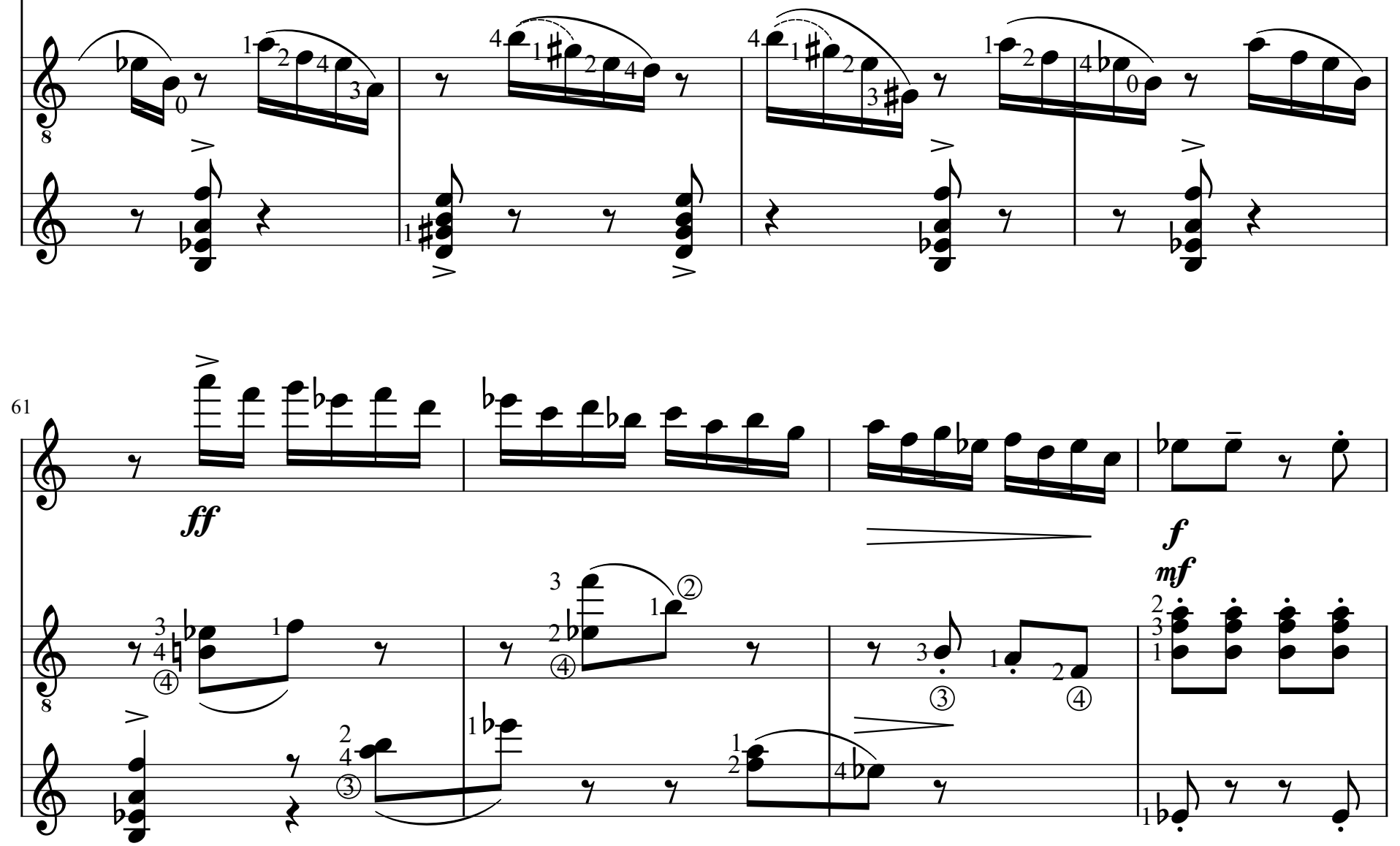

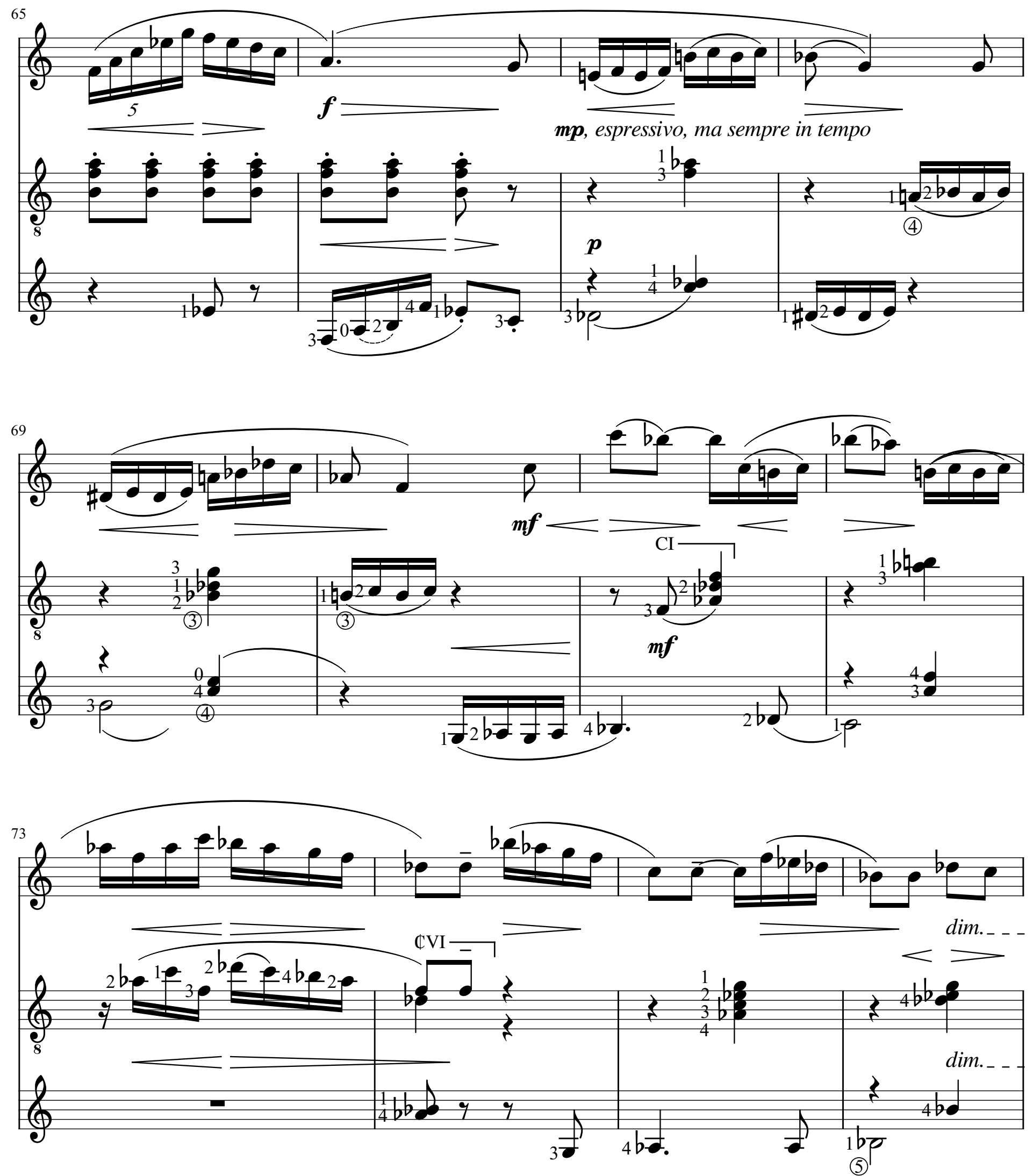

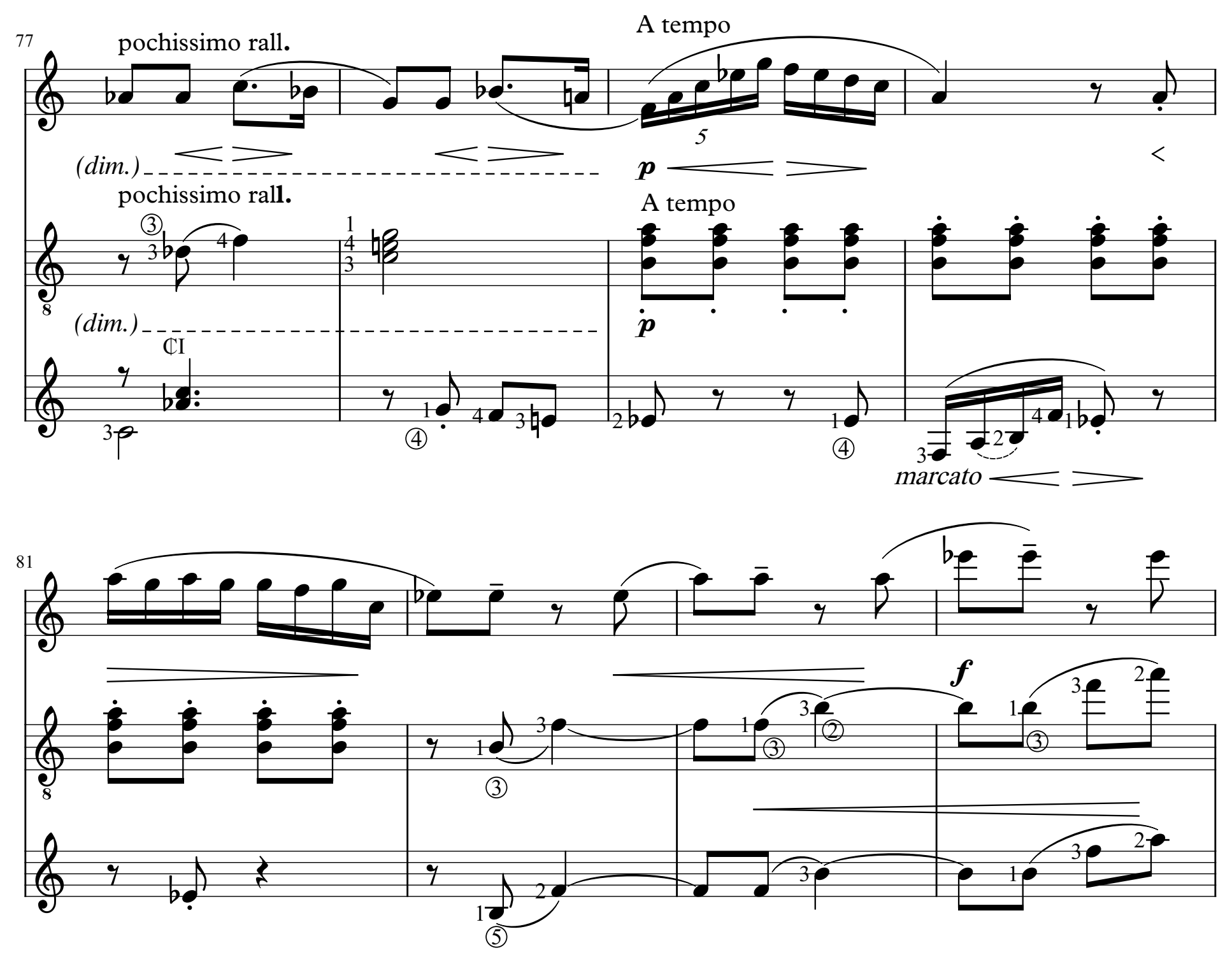

pochiss. rall.

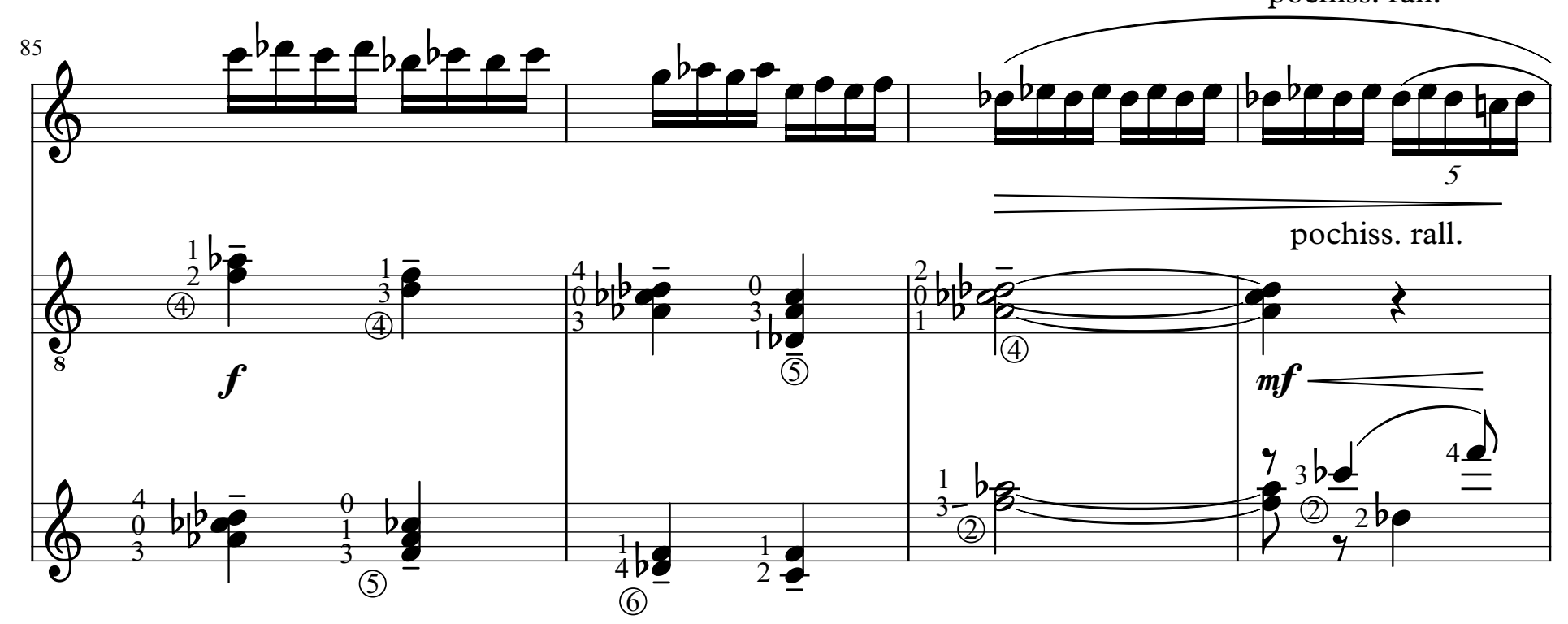



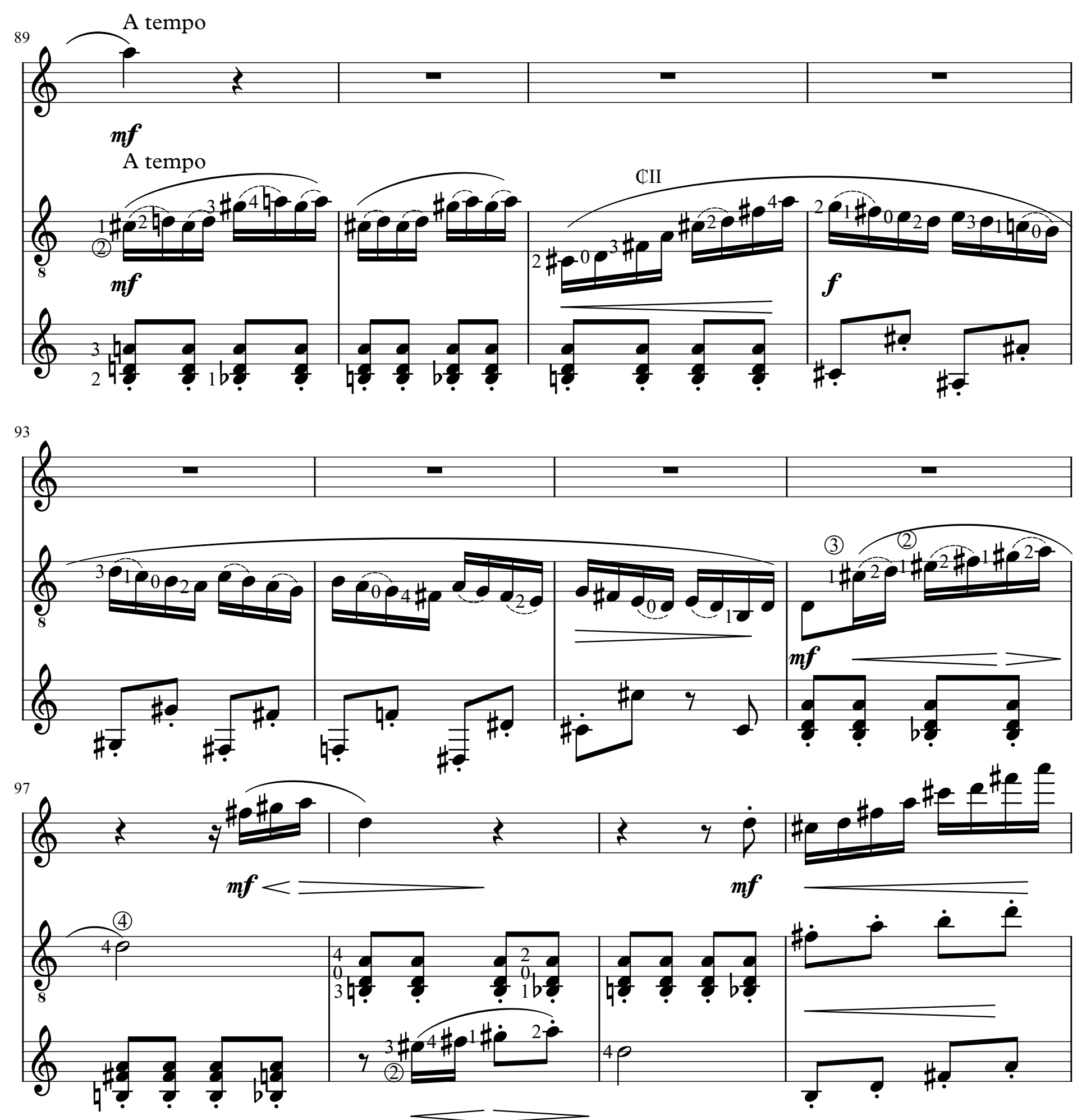

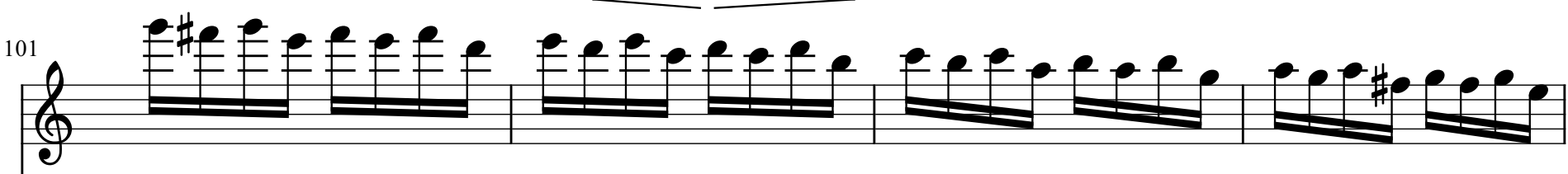
$b^{f}$ be, 

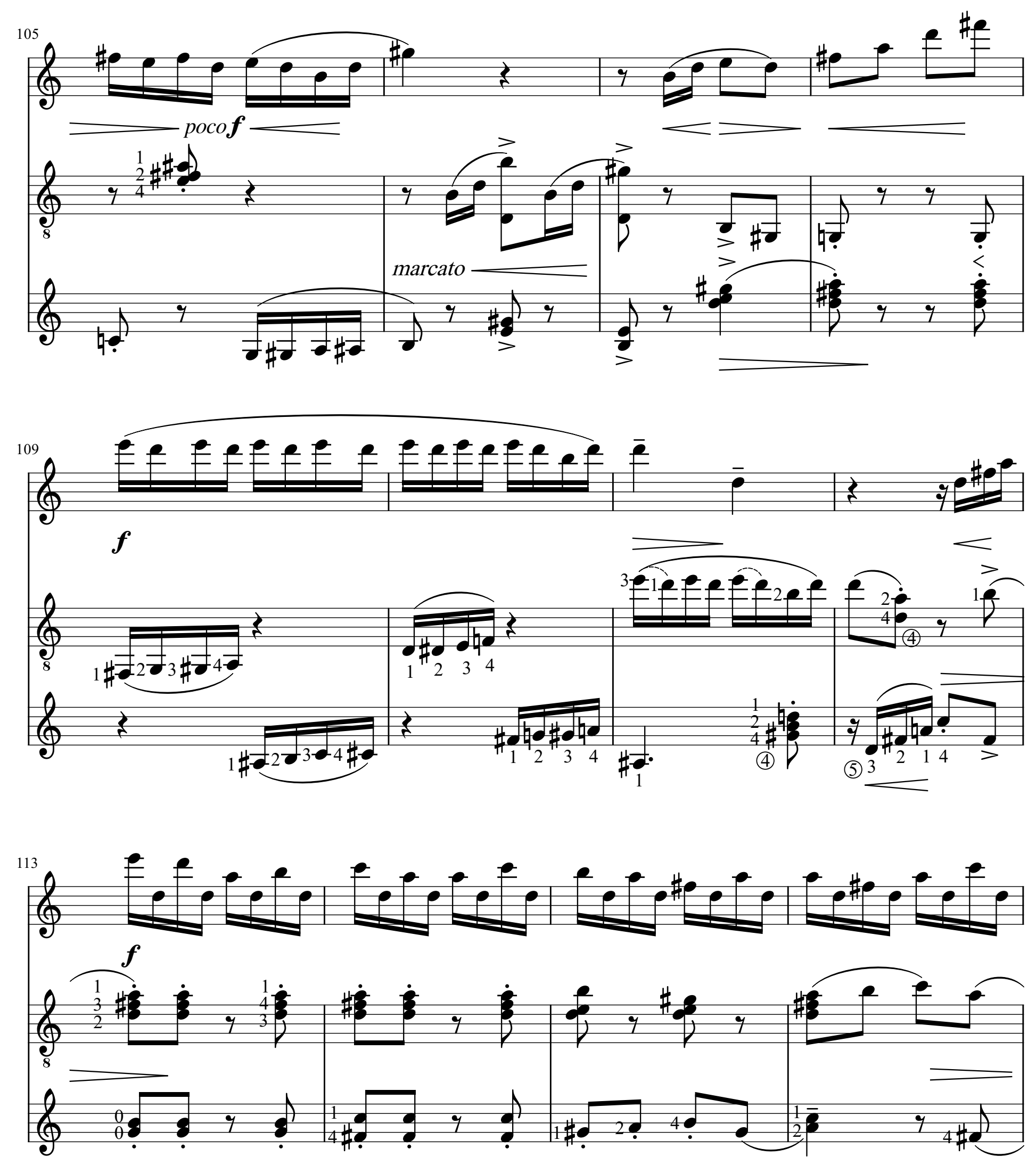

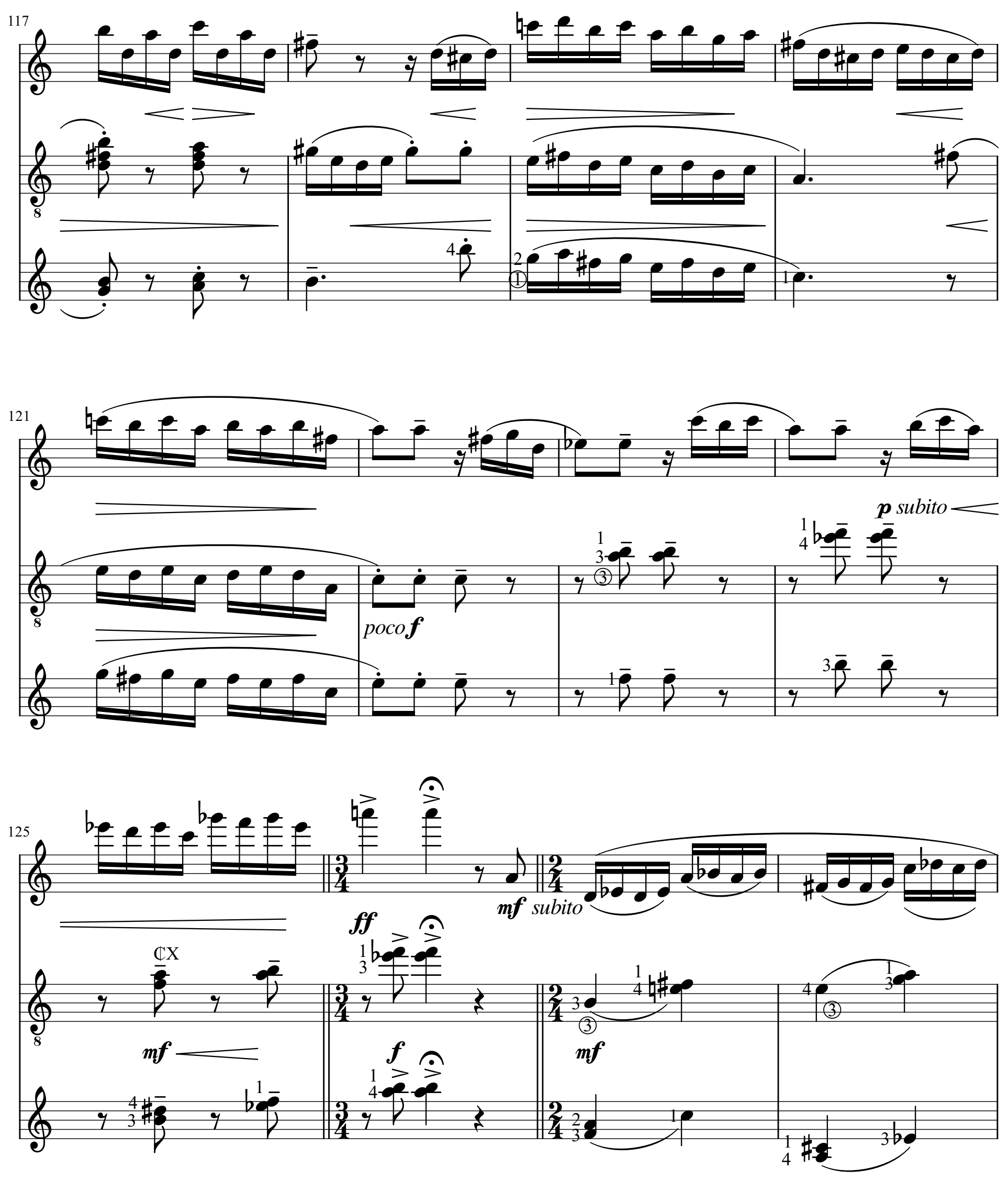


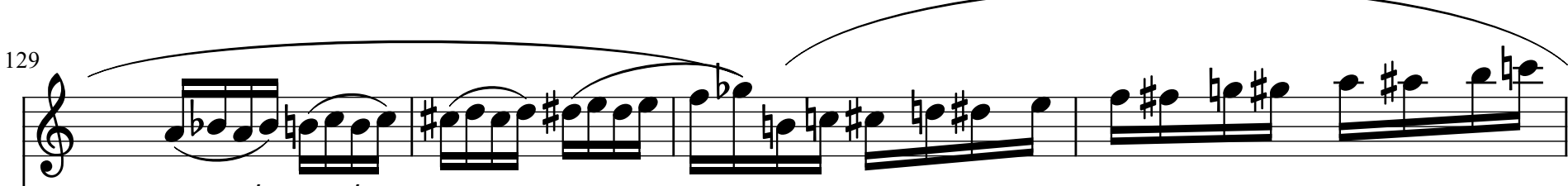
cresc. poco a poco

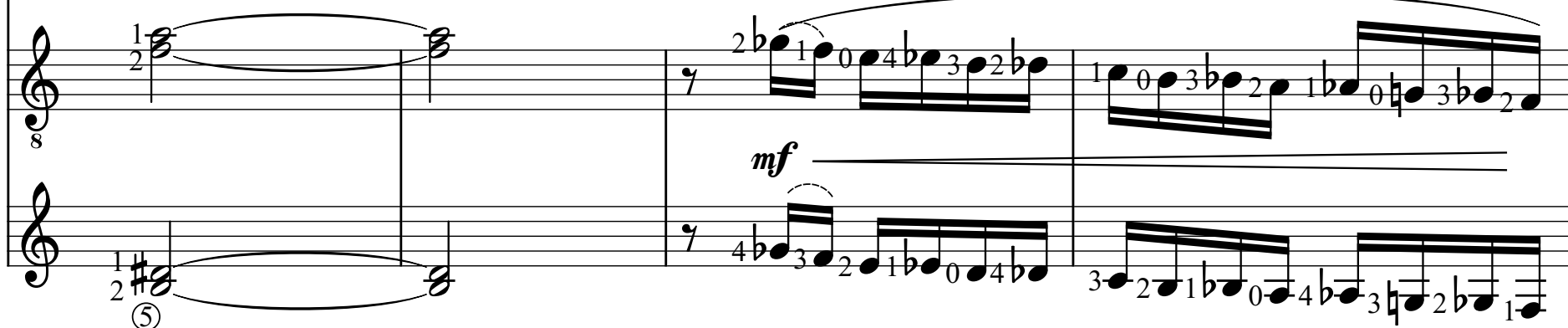

poco rall.

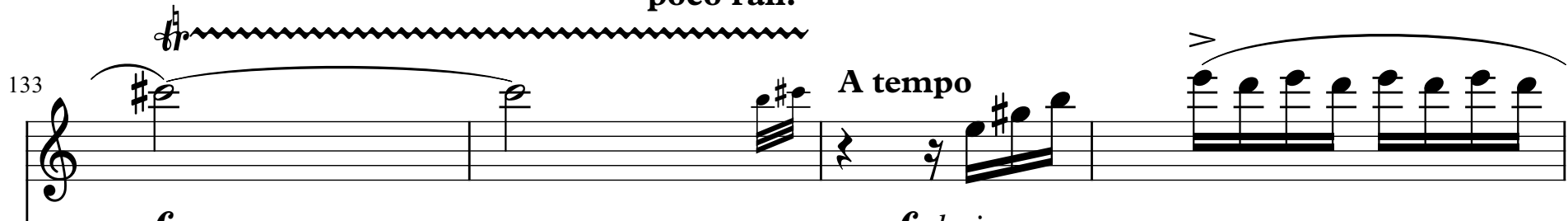
$\boldsymbol{f} \quad$ poco rall. $\boldsymbol{f}$ deciso $<$
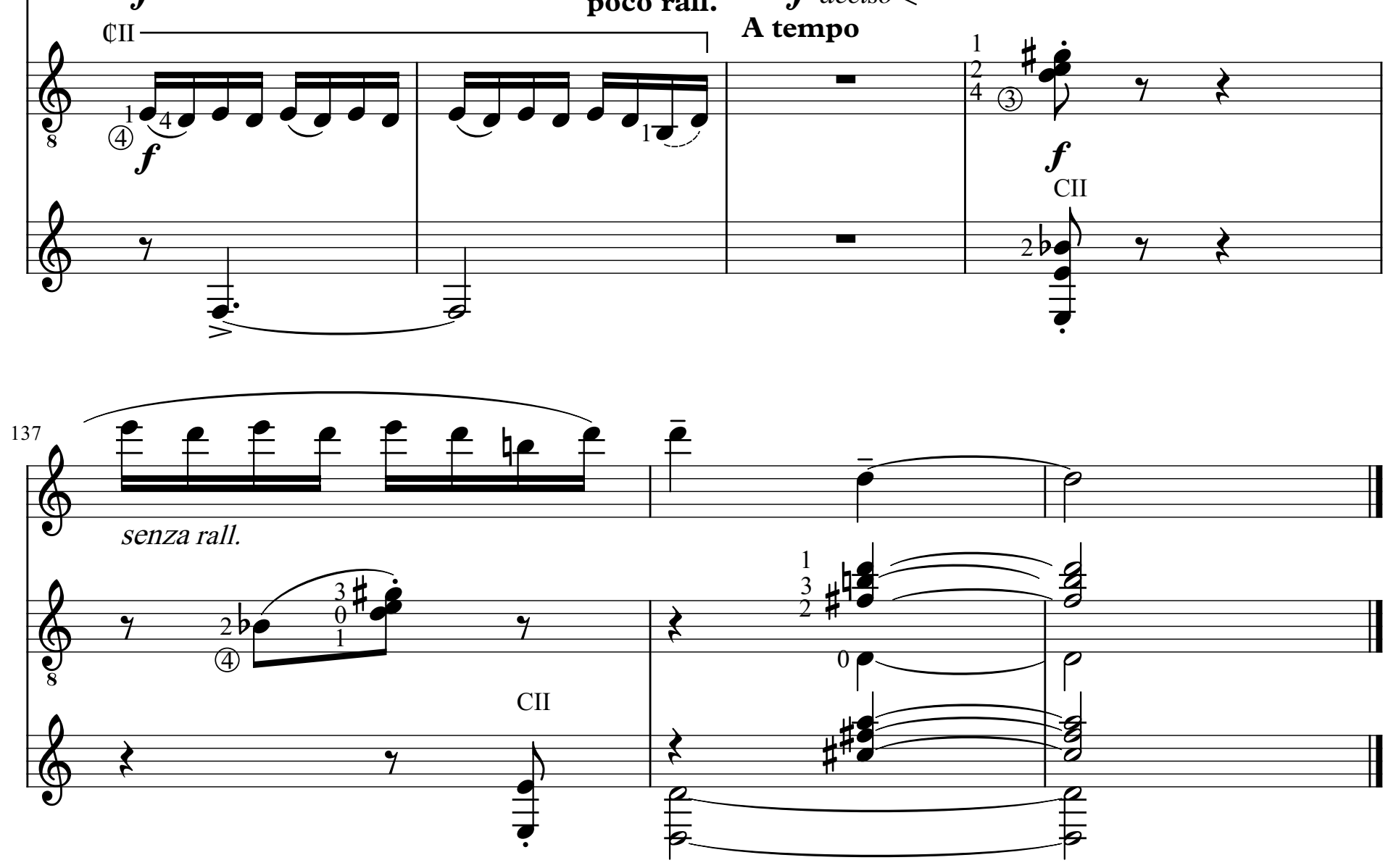

São Paulo, setembro de 1974. 


\section{CONSIDERAÇÕES FINAIS}

Ter um contato com a obra coral de Osvaldo Lacerda foi, num primeiro momento, uma experiência única. Na época em que fazia parte do Coro de Câmara Comunicantus, fomos apresentados à algumas de suas peças, as quais lemos, ensaiamos e apresentamos posteriormente em programas de concertos. Eram belas peças de temática religiosa, com um altíssimo grau de rigor nas indicações musicais e emprego de constantes e modos da música brasileira. Tamanho também foi o prazer de conhecer sua obra escrita para violão, sendo possível discutir questões de performance, sob um ponto de vista da prática violonística, podendo-se notar a influência de seus mestres em sua escrita. A priori, as partituras não pareciam completamente idiomáticas, com trechos um tanto desconfortáveis. Mas justamente essa dificuldade, viria a ser o quebra-cabeça que mantém o interesse e estudo sobre as peças.

Ao interagir com obras de autores não violonistas, em raras exceções, verifica-se a necessidade de uma revisão, tarefa que cabe ao intérprete a buscar soluções mais viáveis ao instrumento quando houver necessidade. Invariavelmente, a prática fará com que as peças venham a se tornar exequíveis, aos poucos. É um processo enriquecedor: Por um lado o compositor terá sua obra tocada, e o intérprete, por sua vez, terá que buscar um aperfeiçoamento técnico-musical para realizar uma performance coerente à escrita do compositor.

As obras que vêm a ser mais apresentadas e estudadas no repertório do violão, acabam sendo de certa maneira apontadas por intérpretes que estão em evidência. Porém muitas vezes várias obras, até mesmo de grandes compositores não chegam a ser revisadas e/ou editadas, o que faz com que elas nem mesmo cheguem às mãos dos músicos. A parte mais significativa deste presente trabalho são, efetivamente, as partituras. O processo de revisão, edição e digitação pode vir a ser um primeiro passo para que, aos poucos, a música para violão de Lacerda conquiste lugar cativo no repertório, como mostra a história do violão quando compositores não violonistas começaram a escrever para o nosso instrumento em princípios do século passado. Trata-se de um importante e significativo momento do repertório nacional de concerto. Espero genuinamente que estas edições venham a ser publicadas, disseminadas e tocadas no Brasil e no exterior. 


\section{REFERÊNCIAS BIBLIOGRÁFICAS}

ANDRADE, Mário de. Dicionário Musical Brasileiro. IEB/Edusp, 1989.

Mário de. Ensaio sobre a Música Brasileira. 3a edição, São Paulo: Martins. 1972.

CHUEKE, Zelia (Org). Leitura, Escuta e Interpretação. Curitiba: Ed. UFPR, 2013.

COOK, Nicholas. Beyond the Score: Music as Performance. Oxford: Oxford University

Press, 2014.

CUPERTINO, Fernando P. de Barros. As canções de Osvaldo Lacerda com textos de Manuel Bandeira. Goiás, UFG, 2007. Disponível em: < https://mestrado.emac.ufg.br/p/2789-2007 >. Acesso em: 22 de Julho de 2020.

DUNSBY, Jonathan. Performing Music, Shared Concerns. Oxford: Clarendon Press, 2002.

GLOEDEN, Edelton. O Ressurgimento do Violão no Século XX: Miguel Llobet, Emílio Pujol e Andrés Segovia. Dissertação de Mestrado, ECA-USP, São Paulo, 1996.

Edelton. As 12 valsas brasileiras em forma de estudos para violão de Francisco Mignone: um ciclo revisitado. Tese de Doutorado, ECA-USP, São Paulo, 2002.

. Edelton. 12 valsas brasileiras em forma de estudos. CD, ECLAT, São Paulo, 2018.

GRAÇA, Fernando Lopes; BORBA, Tomás. Dicionário de Música (Ilustrado). $1^{\text {a }}$ Edição, São Paulo: Edições Cosmos-Lisboa, 1963.

LACERDA, Osvaldo. Cantilena. Partitura, 1974. Editora Novas Metas Ltda. São Paulo. . Moda Paulista. Partitura, manuscrita 1961. Cedida pela Fundação OSESP. . Moda Paulista. São Paulo: Editora Ricordi, partitura, 1961. 
. Obra integral para piano de Osvaldo Lacerda. Box com 5 CDs: Paulinas COMEP, gravado entre 2015 e 2017.

. Osvaldo Lacerda - piano e flauta, piano e canto. LP. Maria José Carrasqueira (Piano), Lenice Prioli (Canto) e Antônio Carlos Carrasqueira (Flauta). Gravadora: Marcus Pereira. MPL 9410. 1980.

. Poemeto. Partitura, 1974. Editora Arthur Napoleão Ltda. Rio de Janeiro, 1980.

. Ponteio. Partitura manuscrita, 1959. Cedida pela Fundação OSESP.

Toccatina. Partitura manuscrita, 1974. Cedida pela Fundação OSESP.

. Três canções - para canto e violão. Partitura manuscrita, 1968.

. Valsa. Partitura manuscrita, 1961. Cedida pela Fundação OSESP.

NEVES, José Maria. Música Contemporânea Brasileira. 1a Edição, São Paulo: Ricordi Brasileira, 1981.

PEREIRA, Marcelo Fernandes. A contribuição de Camargo Guarnieri para o repertório violonístico brasileiro. Tese de Doutorado, USP, 2011.

RINK, John. (Ed.) Musical Performance: A Guide to Understanding. Cambridge:

Cambridge University Press, 2006.

. The Practice of Performance: Studies in Musical Interpretation. Cambridge;

Cambridge University Press, 2005.

TEIXEIRA, Paulo Frederico de Andrade. Performance da obra coral de Osvaldo Lacerda: Rigor de escrita e o espaço do intérprete. Tese de Doutorado, USP, 2018. 
VCFZ, Violão com Fabio Zanon: Arquivo dos programas de violão clássico apresentados por Fabio Zanon, originalmente transmitidos pela Rádio Cultura FM de São Paulo. Acessos diversos: <http://vcfz.blogspot.com>.

VERHAALEN, Marion. Camargo Guarnieri: Expressões de uma Vida. Tradução Vera Sílvia Camargo Guarnieri. São Paulo: Edusp/ Imprensa Oficial, 2001.

VOGT, Carlos. Melhores poemas de Guilherme de Almeida. São Paulo: Edição digital, 2013. 


\section{APÊNDICES}

\section{Entrevista concedida pelo compositor Osvaldo Lacerda ao mestrando Fernando P. Cupertino de Barros (UFG) em 2008.}

Nesta interessantíssima entrevista, Lacerda detalha de onde vieram parte de suas inspirações em suas canções de câmara, além de idolatrar alguns de seus ídolos como Mozart e Manuel Bandeira. É possível ter uma pequena noção da personalidade serena e gentil de Lacerda ao lê-lo.

“[...] Em grande parte, o que me levou a escrever esta canção [O Menino Doente] foi porque eu tinha escrito a primeira, Minha Maria... esta foi - não digo inspirada, mas ajudada por um namoro que eu tive com uma "Maria" e, por acaso, eu achei essa poesia ao ler Castro Alves e a inspiração foi instantânea, e eu escrevi. Depois eu me disse: vou fazer uma primeira canção para uma namorada? Era muito mais justo fazer para meus pais... Então, logo me caiu nas mãos e eu acredito muito no destino, [...] eu estava destinado a encontrar essa poesia $O$ Menino Doente num livro do Manuel Bandeira. Então foi isso que me levou a escrever essa canção, para dedicá-la a meus pais e, também, por um fato maravilhoso: é que $O$ Menino Doente possibilita dois acalantos, um caso único, creio eu, pelo menos na música brasileira, de uma poesia que envolve dois acalantos. Um é o acalanto da mãe, que está cansada e adormece... então, uma aparição ao lado da mãe continua... e temos aí um segundo acalanto, que tem que ser diferente do primeiro. Procurei fazer esse segundo acalanto um pouco mais etéreo do que o primeiro. Quanto a essa aparição, o materialista vai dizer que é uma alucinação do poeta; o católico vai dizer que é o anjo da guarda... Eu prefiro a interpretação espírita: enquanto a mãe dormia, o espírito dela continuou velando pela criança. Então, é a alma da mãe. [...] Tudo isso em poucas linhas porque a poesia é sintética. Tem todo um quadro maravilhoso numa pequena poesia. [...] É uma canção descritiva, que tem uma atmosfera penumbrosa: o quarto de uma criança doente e a mãe.

[...] É uma poesia bonita [Cantiga], não tem, assim... Uma motivação especial. No acompanhamento, procurei sugerir um movimento de onda, ondulante, e creio que consegui... É um acompanhamento simples, que depende muito do bom uso do pedal. [...] Agora, passaram-se os tempos e tinha uma aluna minha que era cantora, que queria cantar a Cantiga, mas ela não gostava muito da canção. Como eu queria favorecê-la, eu escrevi com a mesma letra uma segunda cantiga, que é "prima" da primeira. Eu tinha uma especial consideração por essa cantora; quando ela me procurou, ela cantava de soprano, ou melhor, desafinava de soprano... [...] eu percebi que ela estava a caminho de fabricar um calo nas cordas vocais por má impostação da voz que lhe foi ensinada. Foi então que eu a aconselhei a que procurasse um bom professor de canto e foi o que ela fez. Com esse novo professor, ela eliminou o risco de formação do calo e, curiosamente, de soprano passou para contralto. Eu sabia que estaria usando a mesma poesia; não queria me desfazer da primeira canção e queria acertar com a segunda e, por isso mesmo, coloquei Cantiga I e Cantiga II.

[...] Eu defino canção de câmara como poesia cantada. Então, a transmissão para o povo pelo cantor é um fenômeno que demanda atenção tanto para a poesia, como para o canto e o acompanhamento. Eu acho que o canto e o acompanhamento pelo piano, ou por outros instrumentos, são servidores da poesia. Então, é fundamental que eles reflitam a poesia... e o que é o canto senão o aumento da emoção?... Daí eu dar muita importância a fazer uma melodia e o ambiente em função da poesia. Antes de musicar, eu declamo 
sozinho a poesia para sentir o ritmo dela, para entrar no seu âmago e só então é que eu componho, ao contrário de muitos compositores brasileiros que gostam da poesia, entram de mergulho na música e o que acontece? A poesia vai para um lado e a música vai para o lado oposto.

[...] Eu acho que acertei em cheio ao musicar a poesia. E como eu lhe contei agora há pouco, me chamou muita atenção um trecho dessa poesia [Poemeto Erótico], onde ele [Manuel Bandeira] diz com referência à amada: "quero possuí-la no leito estreito da redondilha". Isto, para mim, é um dos maiores achados da poesia brasileira, mesmo sem ter a pretensão de conhecer toda a poesia brasileira, mas é uma coisa tão espiritualizada, tão única!... E sabe por quê? Porque ele diz: "quero possuí-la". Como? Na cama? Não! Ali ele quer possuí-la na poesia que está fazendo. Então ele diz: "quero possuí-la no leito estreito da redondilha". O que é a redondilha? É um tipo de verso de 5 - que é a redondilha menor - ou de 7 sílabas, que é a redondilha maior. Foi essa a imagem que provocou, em grande parte, a composição. [...] Dentro dessa mina de produção poética de Manuel Bandeira, encontrei essa poesia, que caía no meu jeito e foi a primeira que eu fiz mais ou menos no estilo de seresta. Ela pegou o segundo lugar no concurso. Foi o meu primeiro prêmio em concursos de composição.

[...] Eu tenho uma certa inclinação para a música dramática. Eu teria gostado de ter tido a oportunidade de compor uma ópera... seria uma ópera bem brasileira e não muito longa, mas por vários fatores eu não escrevi a ópera. Então eu me voltei para algumas poesias de caráter dramático. Aqui [sobre Poema Tirado de uma Notícia de Jornal], Manuel Bandeira descreve o drama da vida de uma pessoa do povão. Entretanto, a música não é dramática, mas sim, narrativa, na medida em que flui na sequência de uma narrativa, como de quem lê mesmo uma notícia de jornal.

[...] Durante muito tempo eu não ousei invadir dois ídolos, o Mozart e o Manuel Bandeira, mas esse Mozart no céu, assim que eu li resolvi musicar. Teria que ser uma coisa muito inspirada. E essa inspiração levou muito tempo para aparecer, mais de quarenta anos. Até que me veio essa ideia, que me pareceu uma boa inspiração: por que não fazer uma canção com trechos de Mozart? E foi o que eu fiz. Então é uma canção que tem trechos de Mozart, com, naturalmente, uma harmonização minha. Agora, tem um problema: essa canção só pode ser plenamente apreciada por quem conhece a obra de Mozart. Então, quando ela é cantada numa oportunidade em que eu esteja presente, eu peço ao cantor - ou eu mesmo o faço, que diga quais são os trechos que eu utilizei e, enquanto isso, o pianista toca aqueles trechos para que haja uma apreensão plena do ouvinte. [...] Toda obra de arte depende de duas qualidades opostas, mas necessárias: coerência e variedade. É fundamental haver coerência no seguimento da música, não ficar repetindo. Sempre a mesma coisa, o que é insuportável, ou se repetir, repetir variado, o que é a variedade. Foi o que procurei na escolha dos temas, porque, modéstia à parte, eu estou bem por dentro da produção de Mozart. E fui fazendo... quando escolhia e trabalhava um tema, ficava pensando qual seria o próximo... E aí me vinha a ideia e fui fazendo aos poucos, sempre com uma inspiração puxando a outra." (Lacerda, Osvaldo apud CUPERTINO, Fernando. 2008) 


\section{ANEXOS}

A)

Prêmio Vídeo Pós-Graduação USP 2019

"Osvaldo Lacerda - Obra para violão"

Disponível em: https://youtu.be/nw-EHZoO8xQ

B)

Partituras manuscritas

Violão solo:

Ponteio

Valsa

Moda Paulista

Voz e violão:

I. As dádivas

II. Vácuo

III. Saudade

C)

Versões inacabadas e partituras originais para flauta e piano

Poemeto

Cantilena

Toccatina 


$$
\begin{gathered}
\text { OSVALDO LACERDA } \\
\text { PONTE/O } \\
\text { PRA VIOLÃO } \\
\text { (1959) }
\end{gathered}
$$




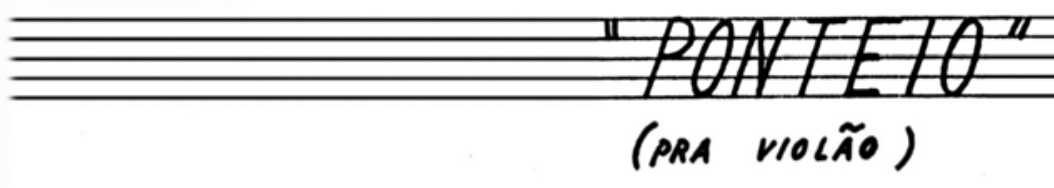

SEM PRESSA $(d \pm 50 ; f \pm 100)$

(2) cantands

$$
m f \underline{L}
$$

$=$
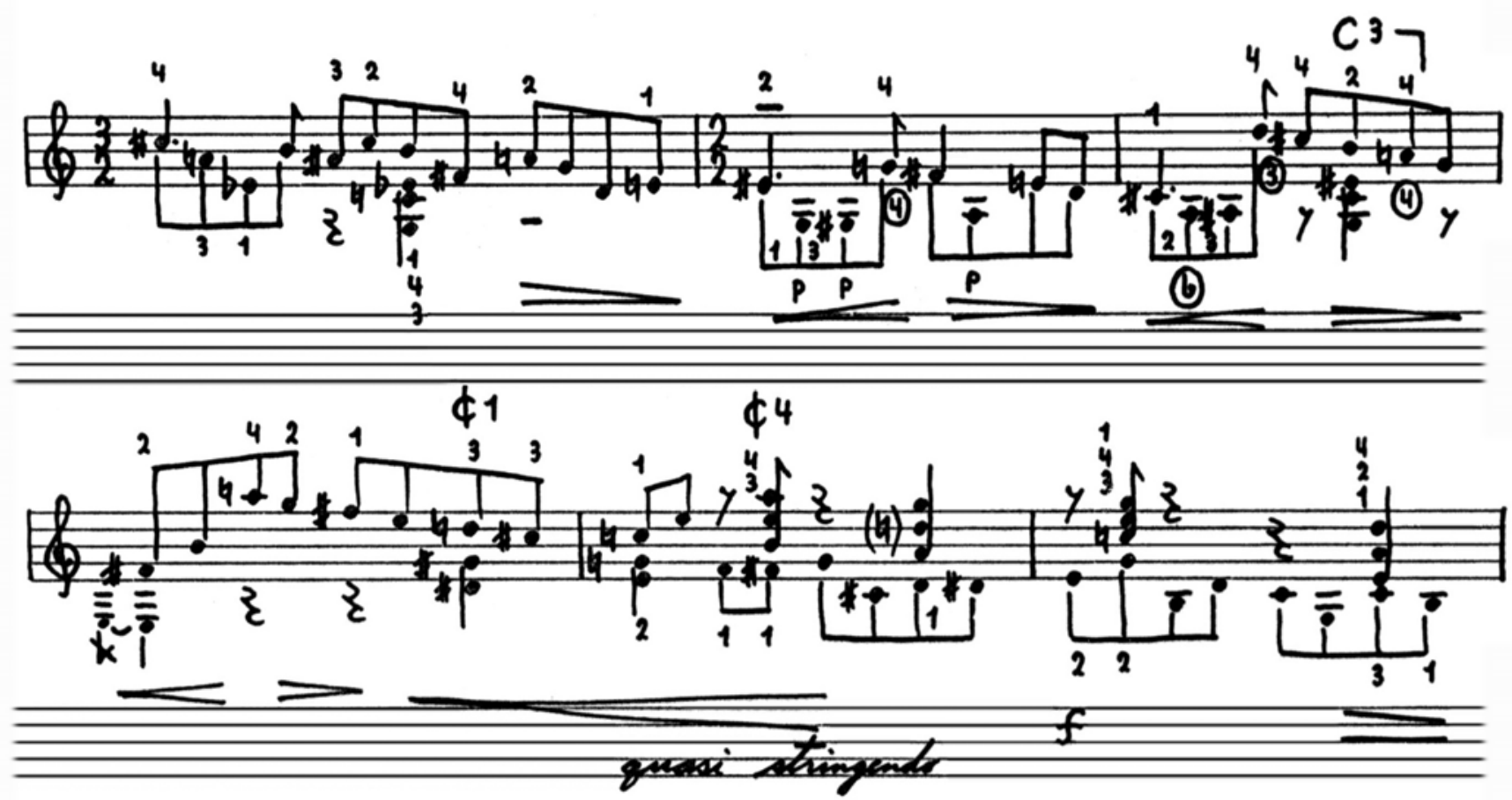
poes a poes sittremder

(42 है

(2)

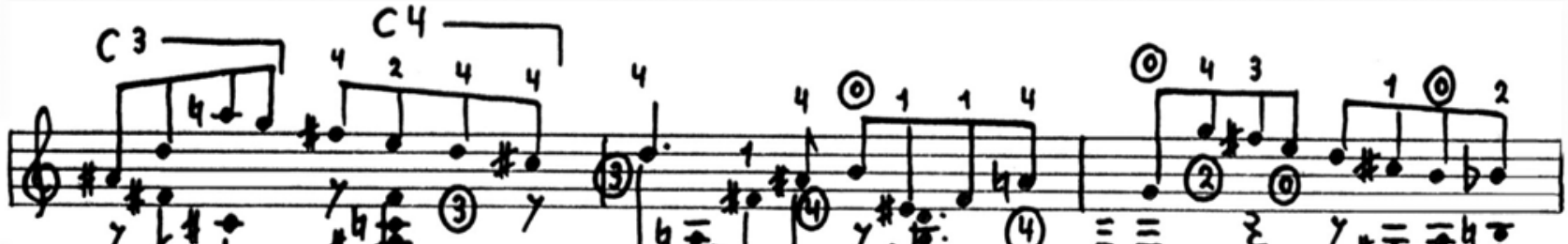

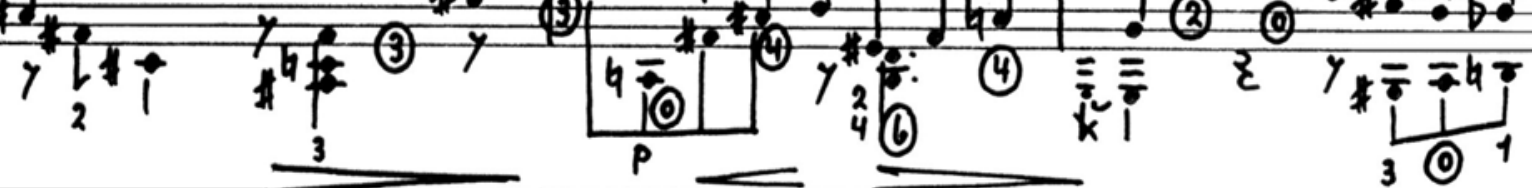

$=$

C7

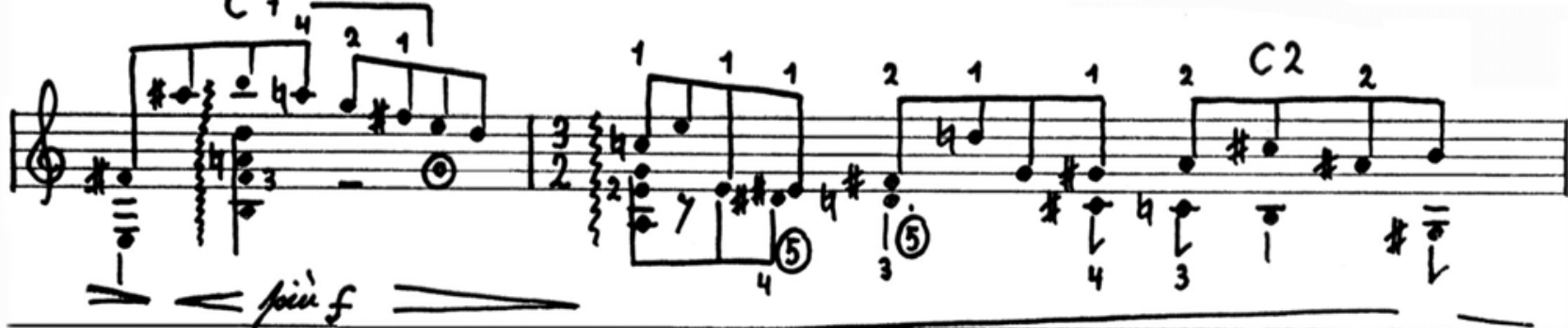

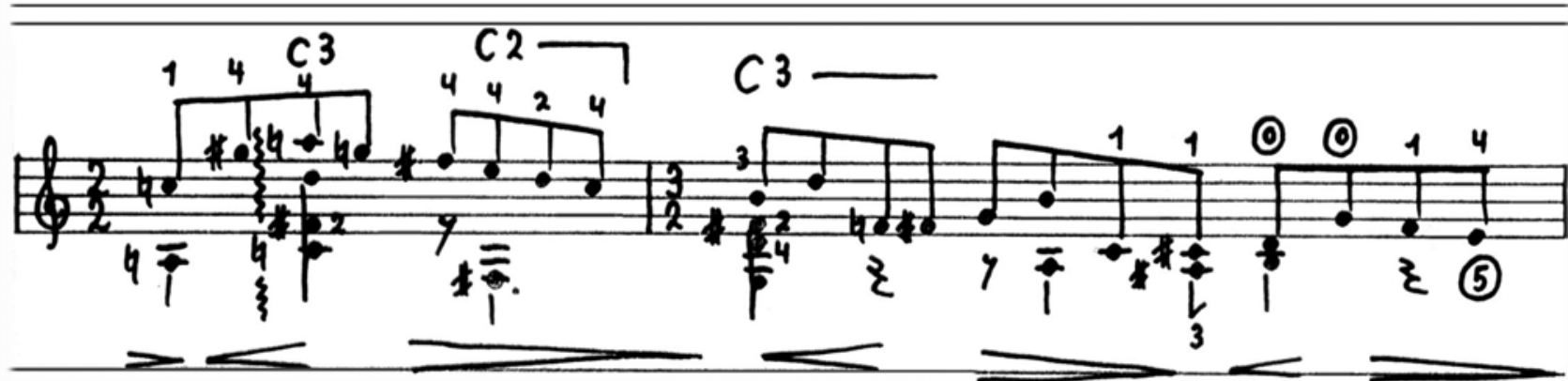


(3)

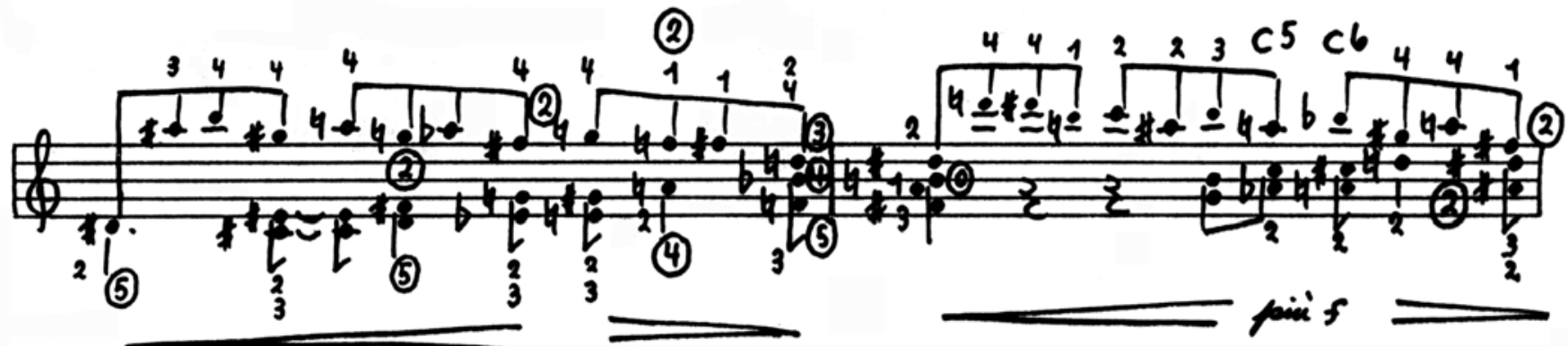

1.

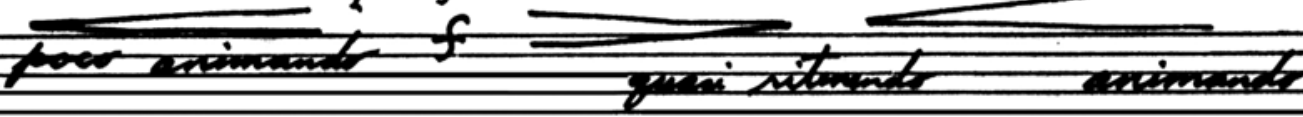
(잉
$\overbrace{1}$

rachond

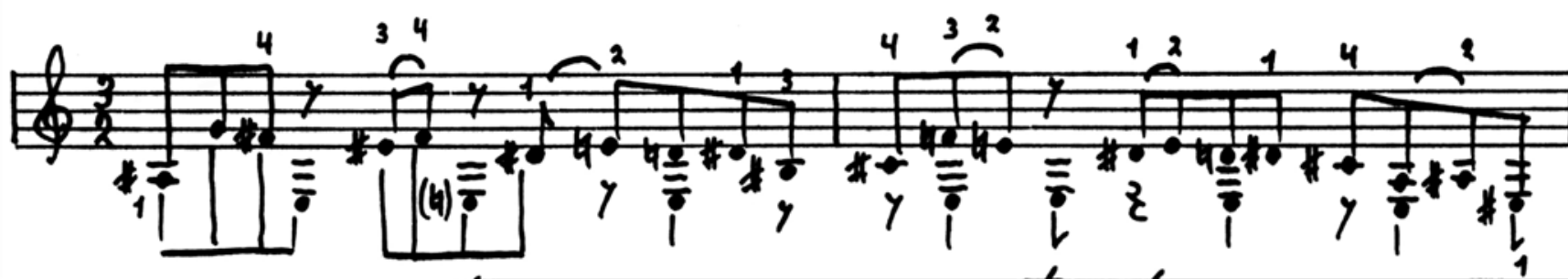

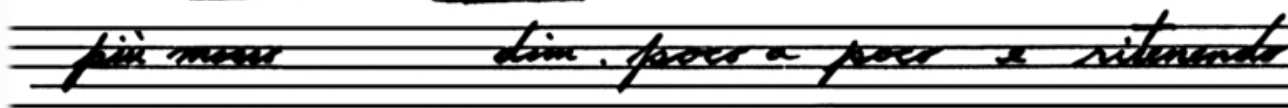

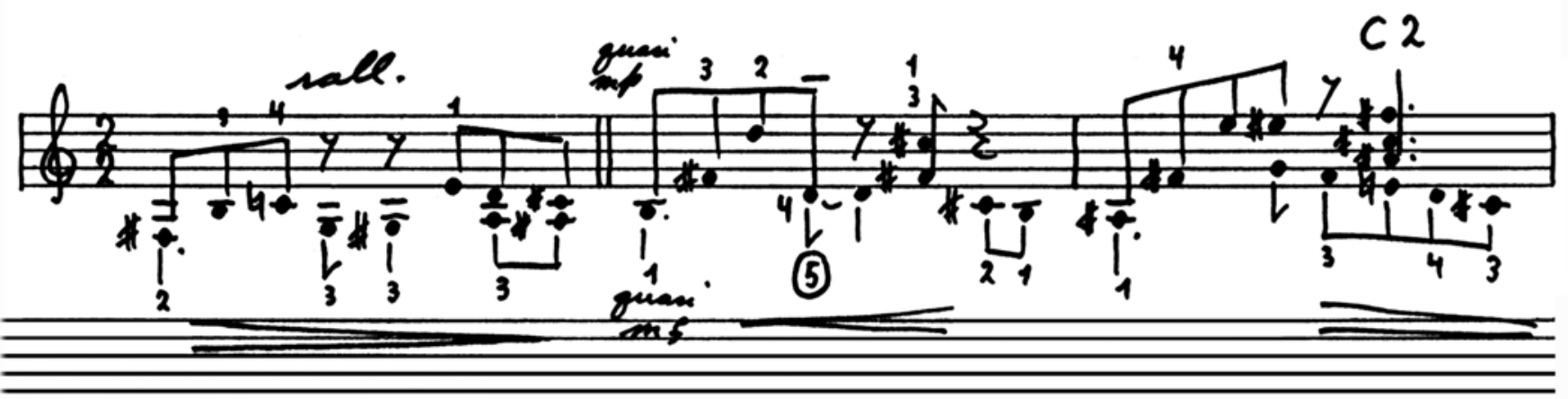

$\underbrace{0}_{1}$ 


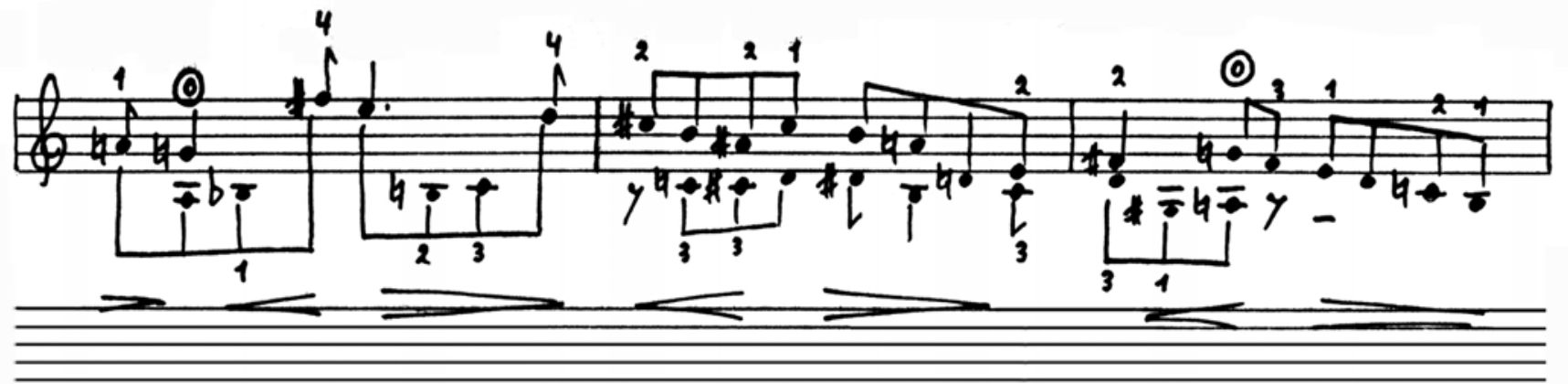

(4)

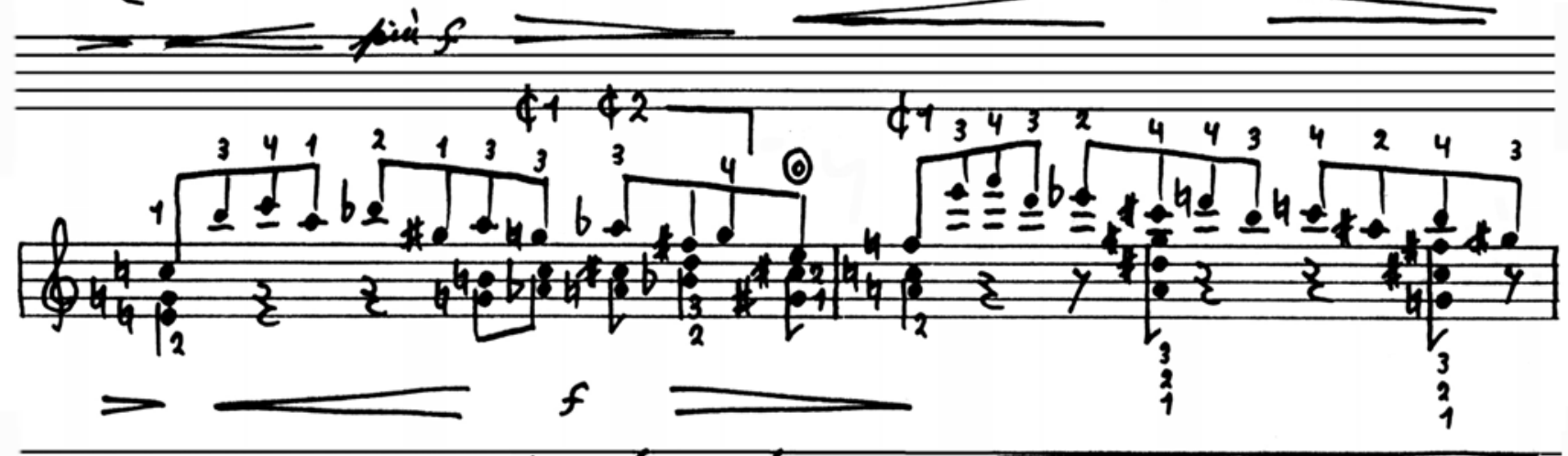

\section{and chench}

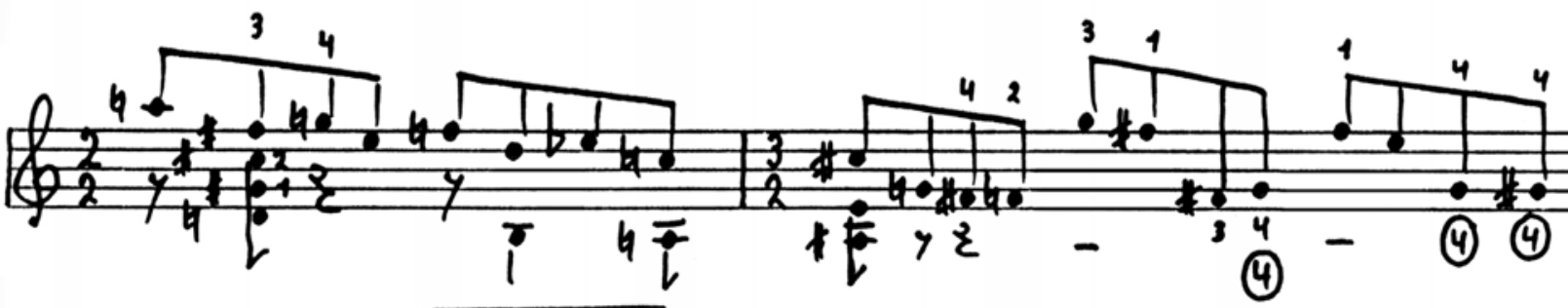

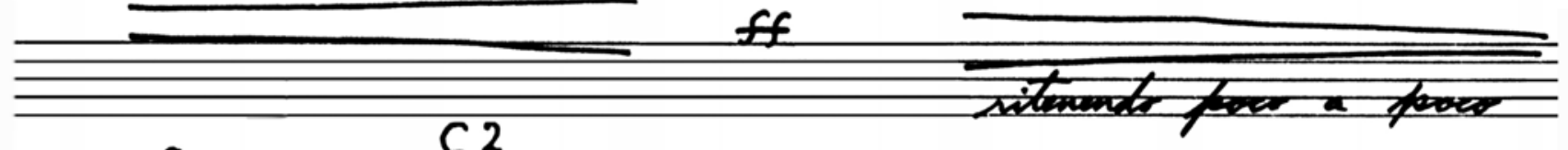

(1) C2

Q(2)
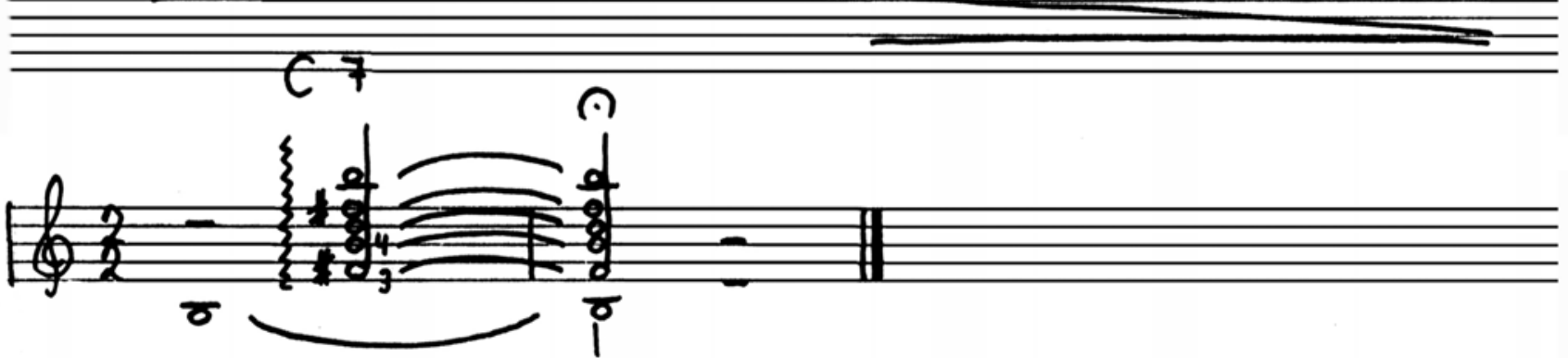

$=m \alpha$

৩ 
OS (A) ICA

(1)

(tenceriote) 


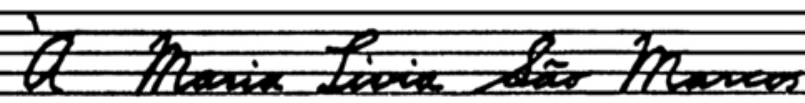

$$
\begin{aligned}
& \text { "IALSA" } \\
& \text { (pra violios) }
\end{aligned}
$$

QSt (7969)

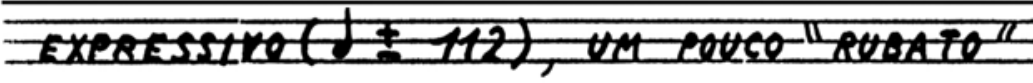

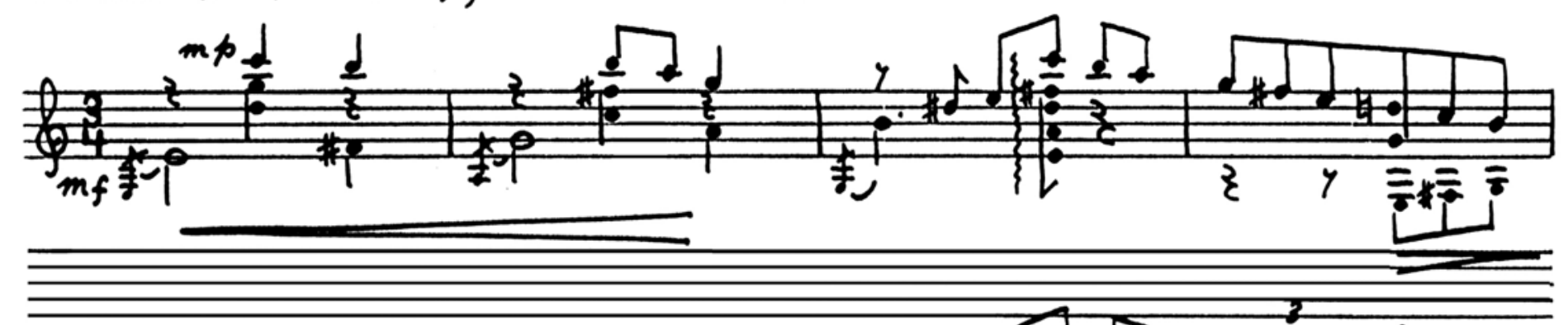

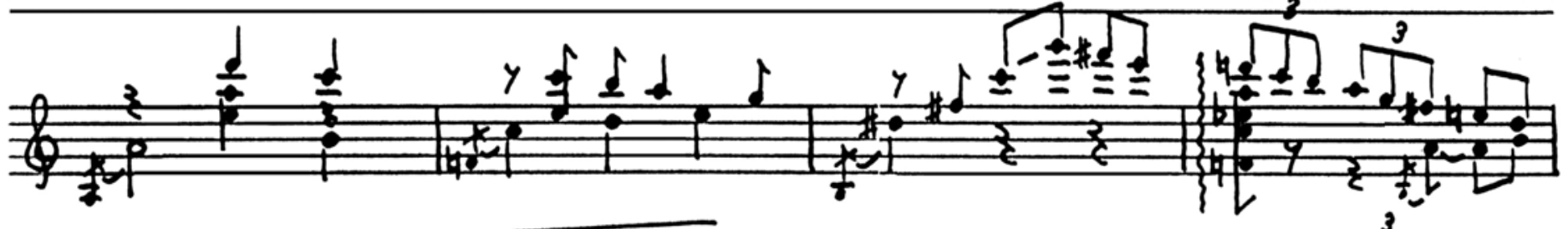

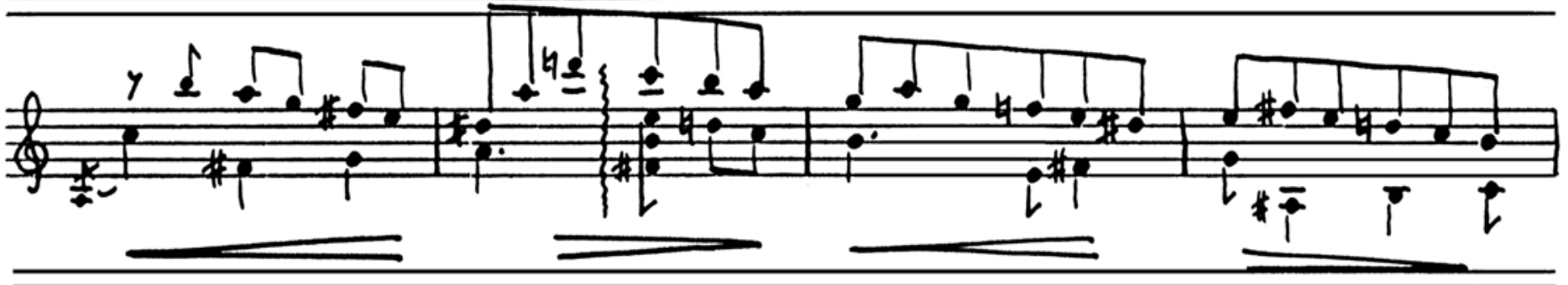

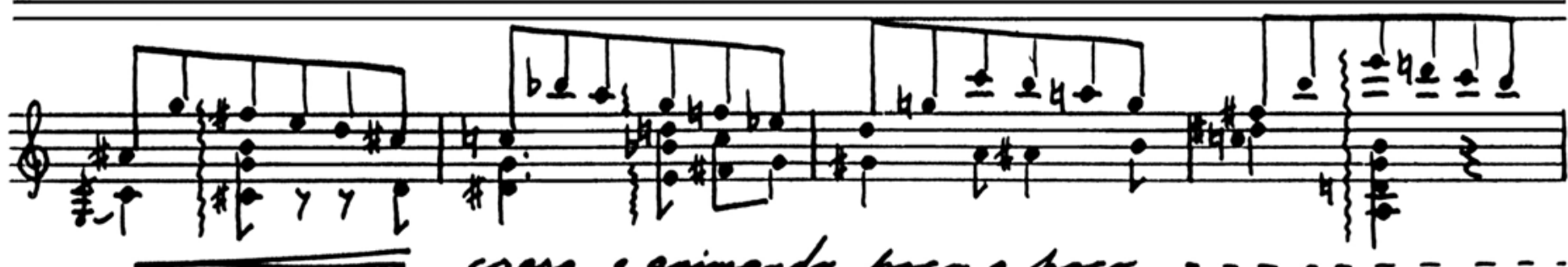

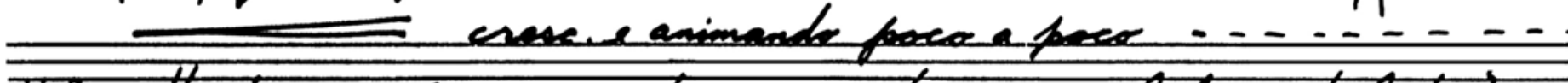

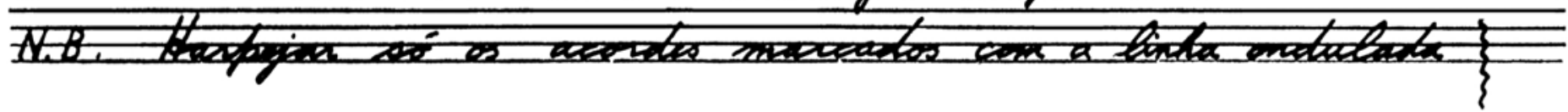


(2)

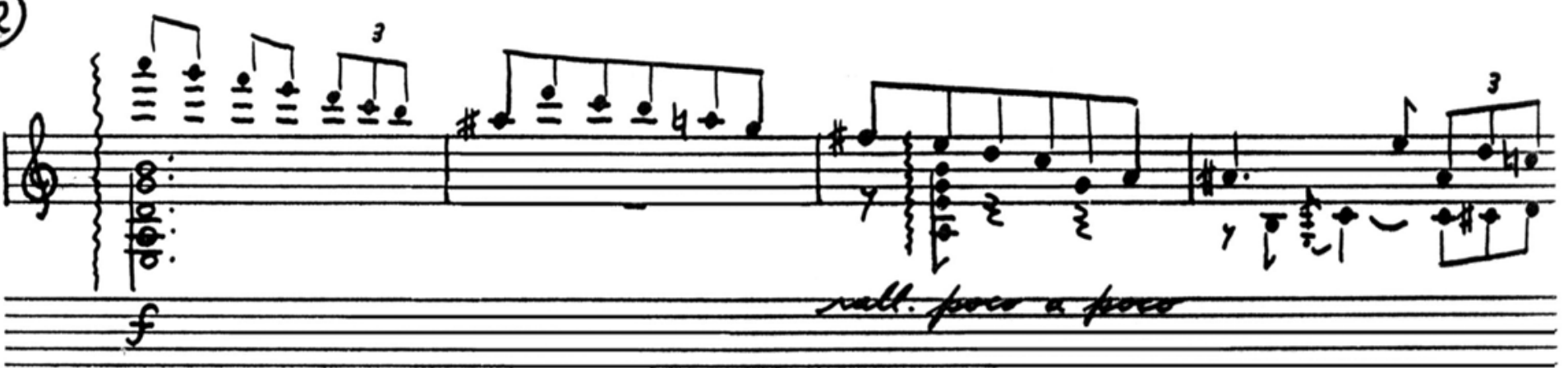

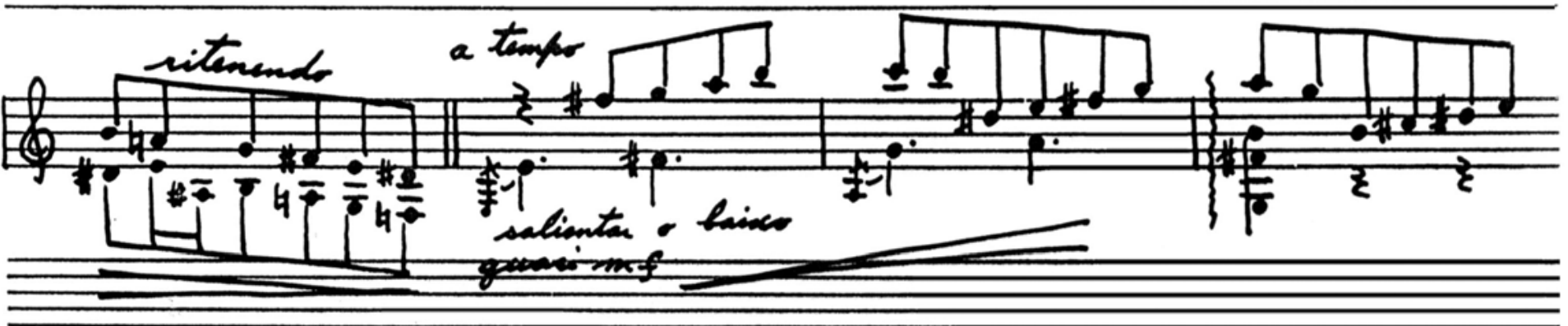
(1)

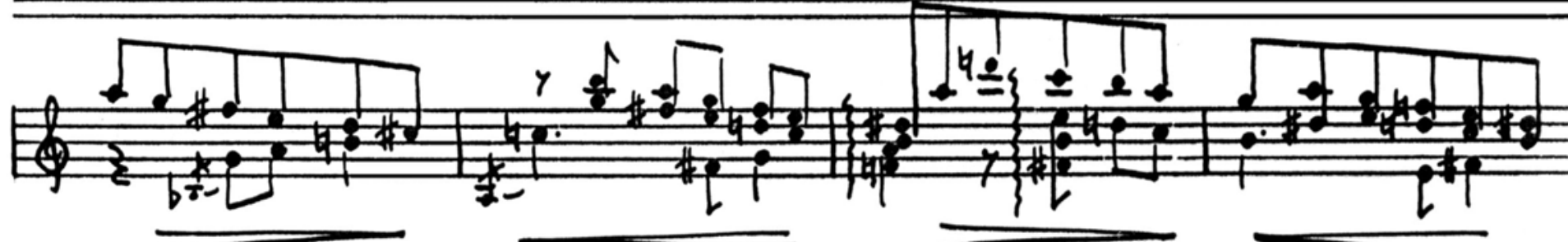

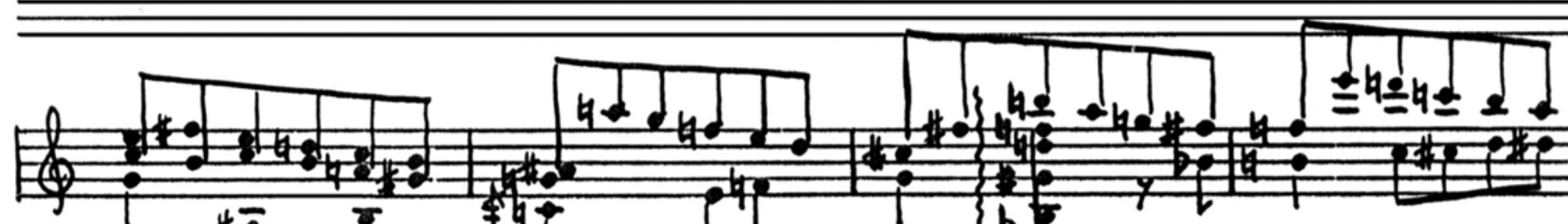
杆 i 耤 creace poedian.

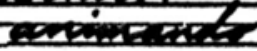


ton. $t_{\text {m. }}$. MAIS DEPRESSA $(! \pm 152)$

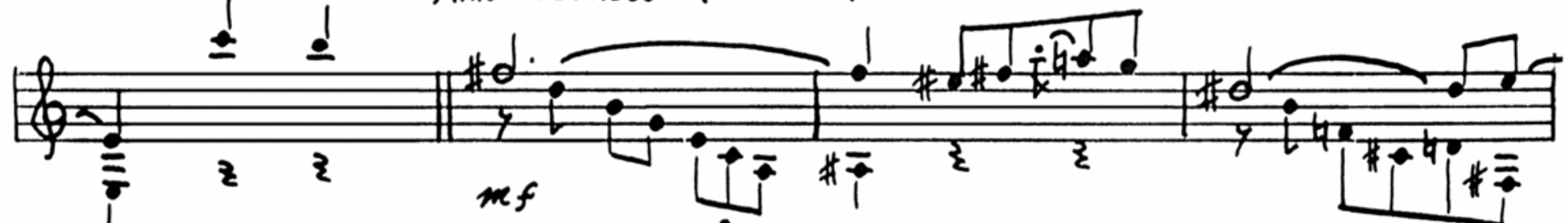

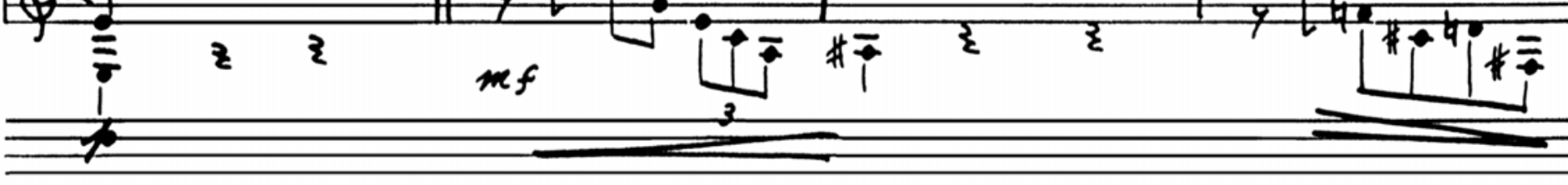

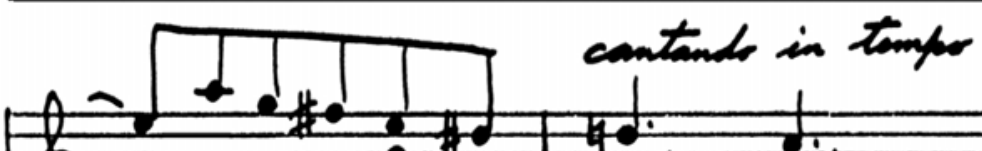

$e_{\bar{j}}^{\bar{i}}$ ह

20

(3) $=\quad \sqrt[5]{\bar{F}}$

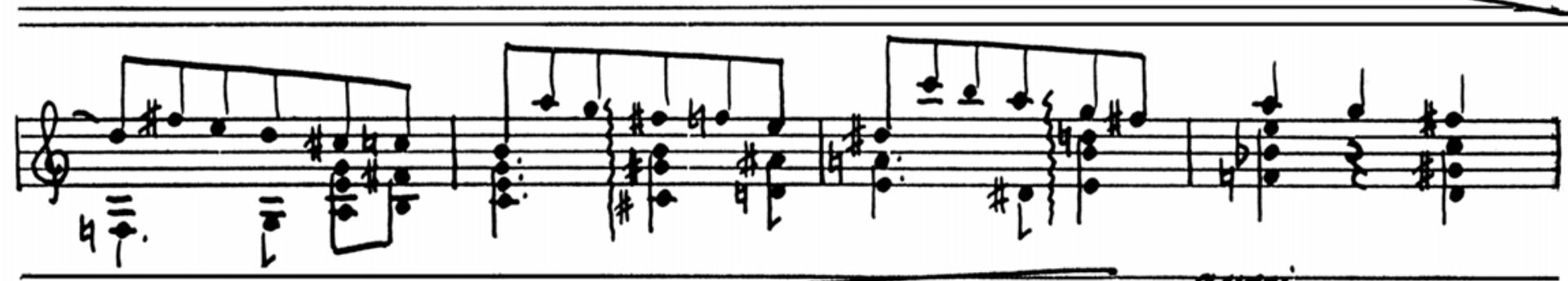

$4 \overline{\%} \quad \overline{\bar{F}} \bar{F} F$

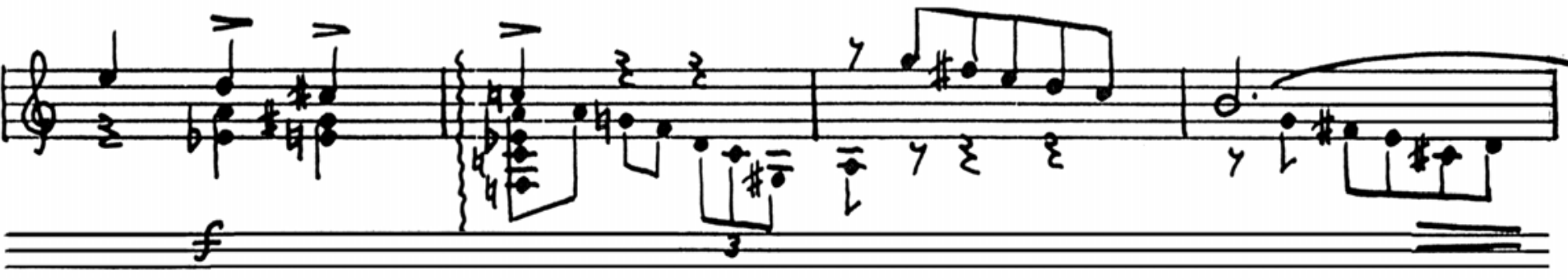

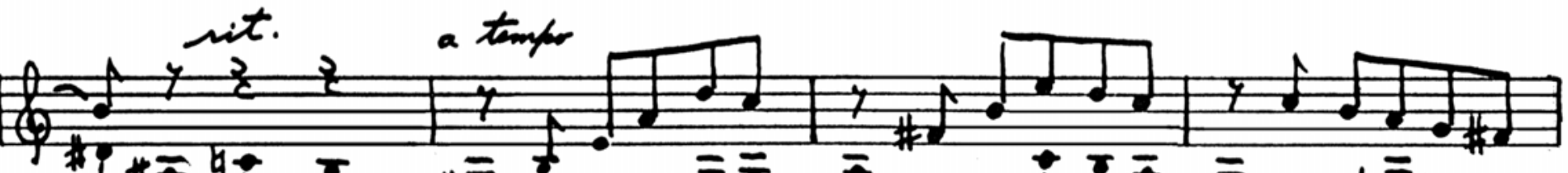

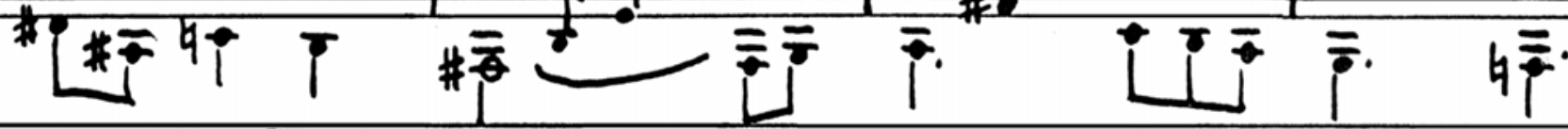


(4)

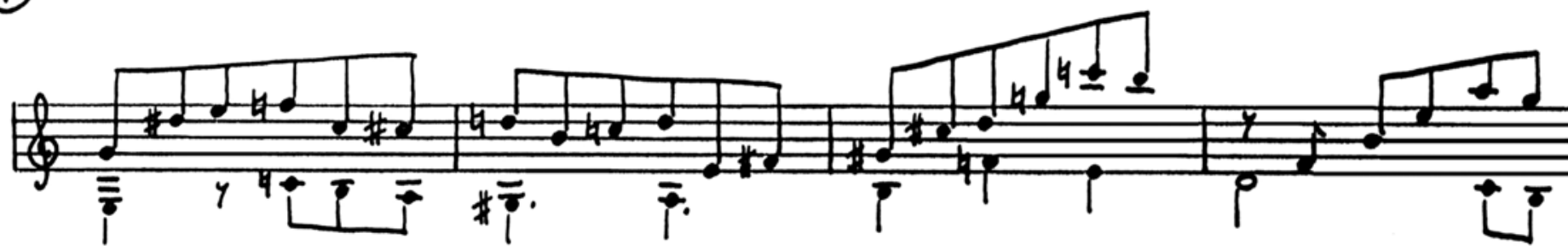

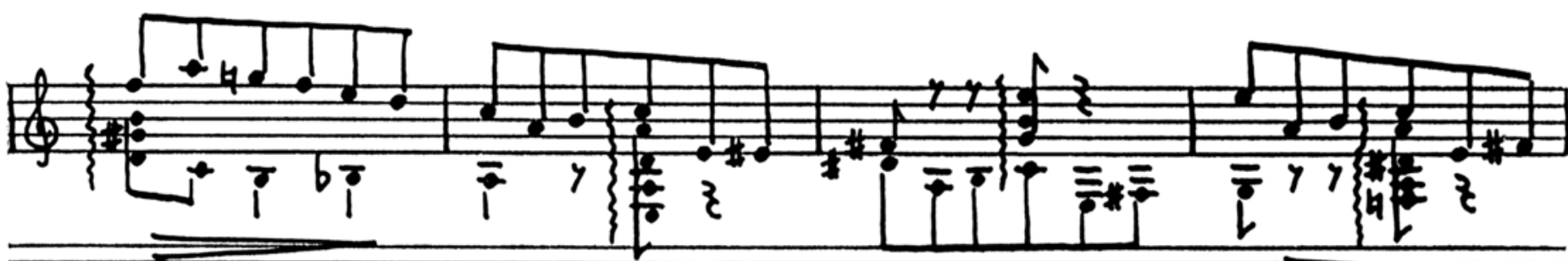

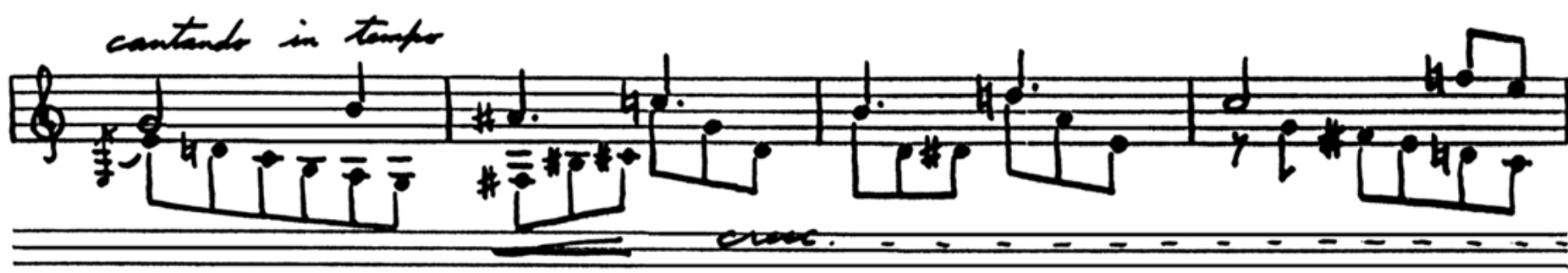

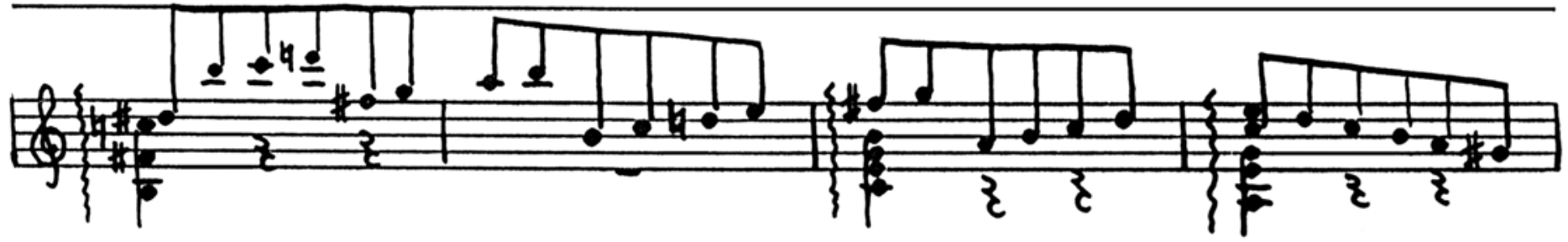
f and

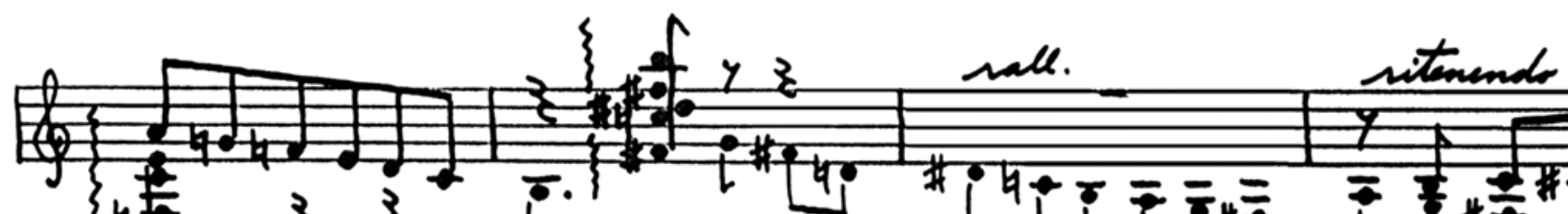

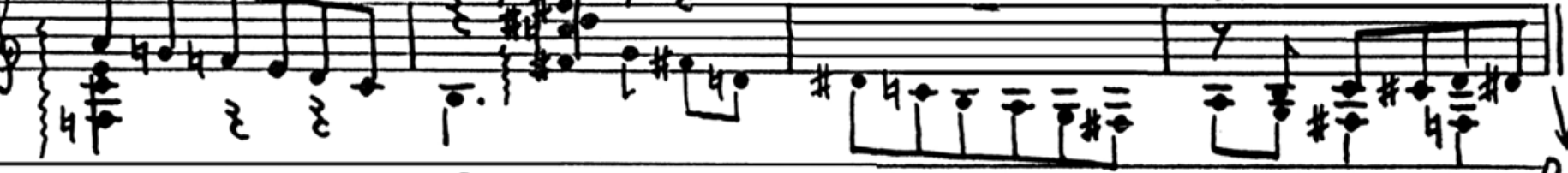
COOA f (1) (2) 


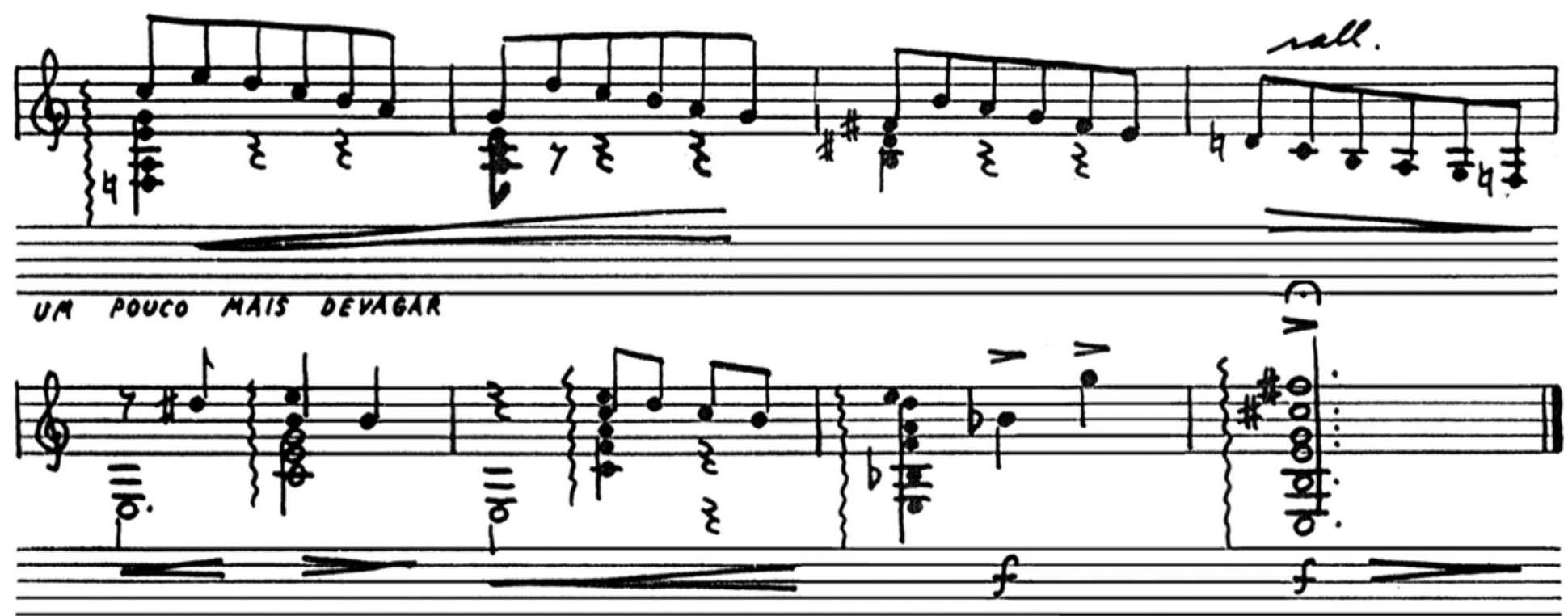

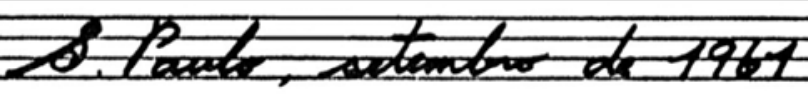


QSWAL LACERA

"1)

(4) viotise) 


\section{"PONA PIUISFA"}

Ototracto de

MANOEL SAEO MARECS
MÚSICA DE

OSTALDO IAEERDA (1961)

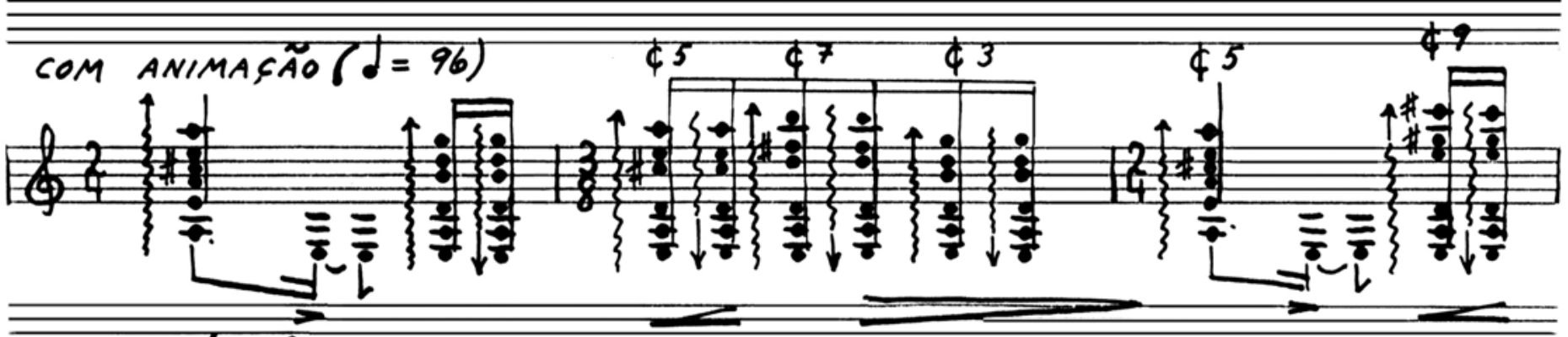

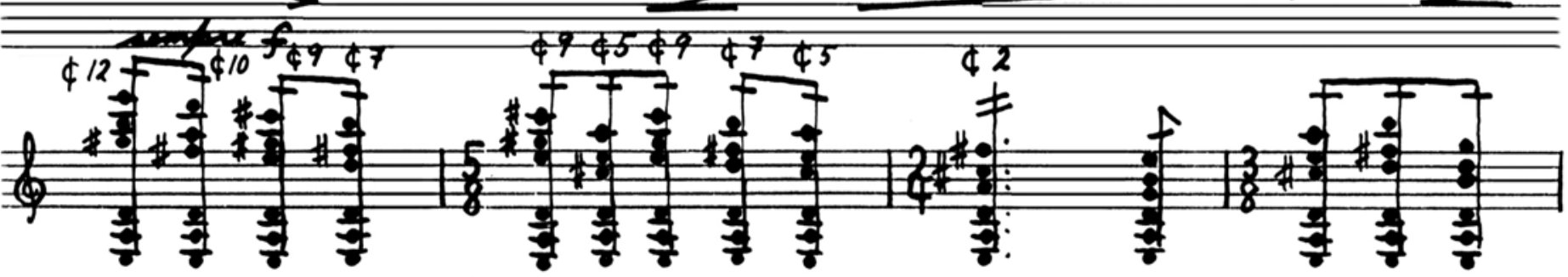

(ximide, vondos)
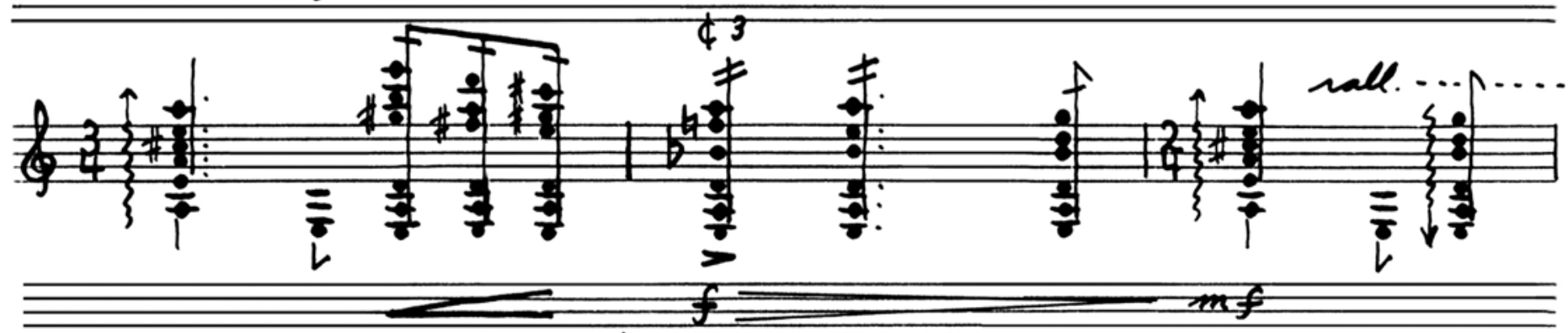

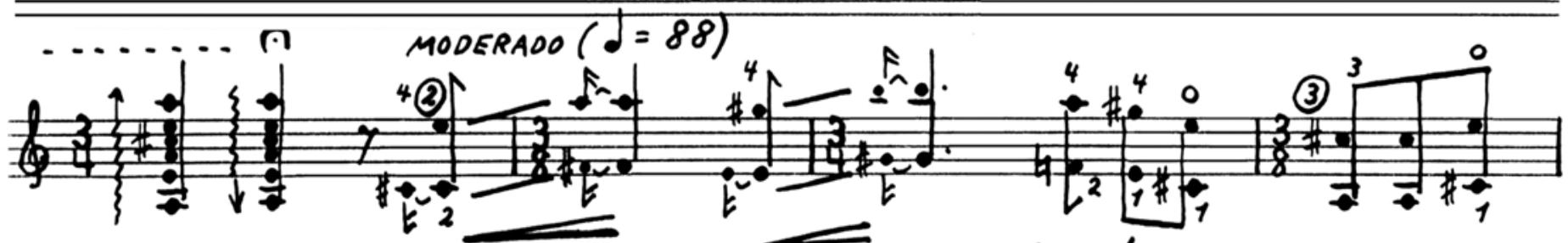

mp, antanto

(simile)

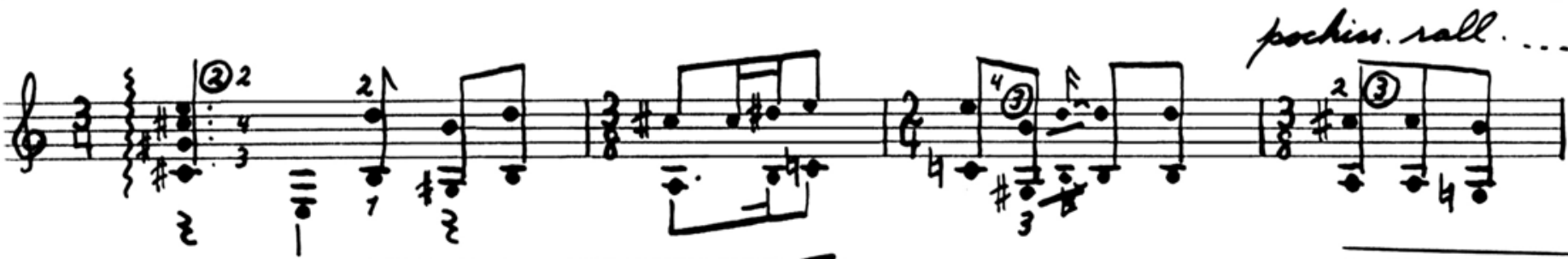

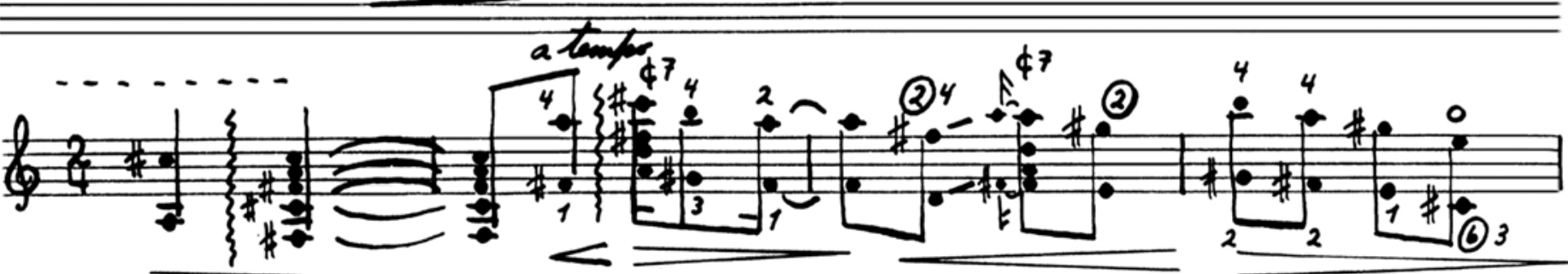


dom

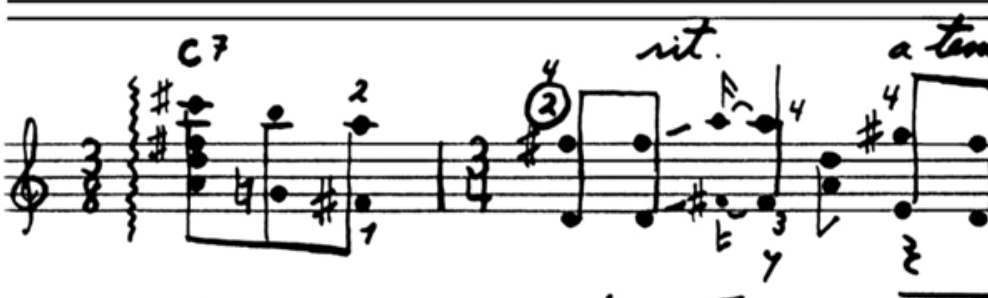

$m p<$

$m f$

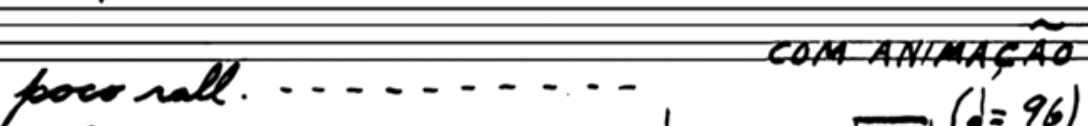

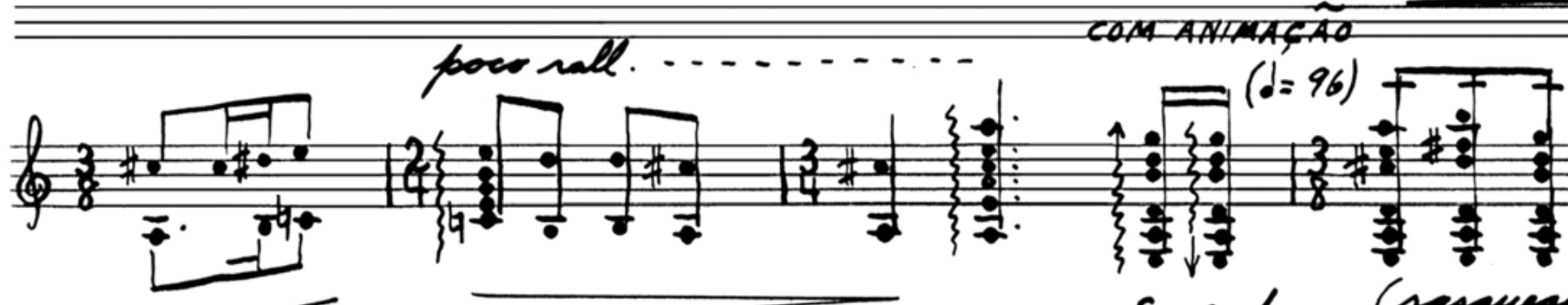
famphe (neygunato)

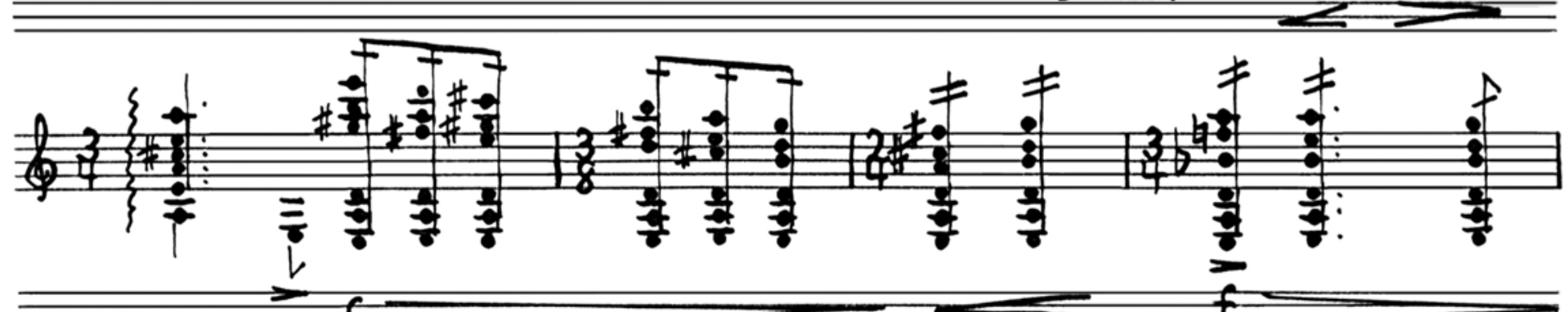

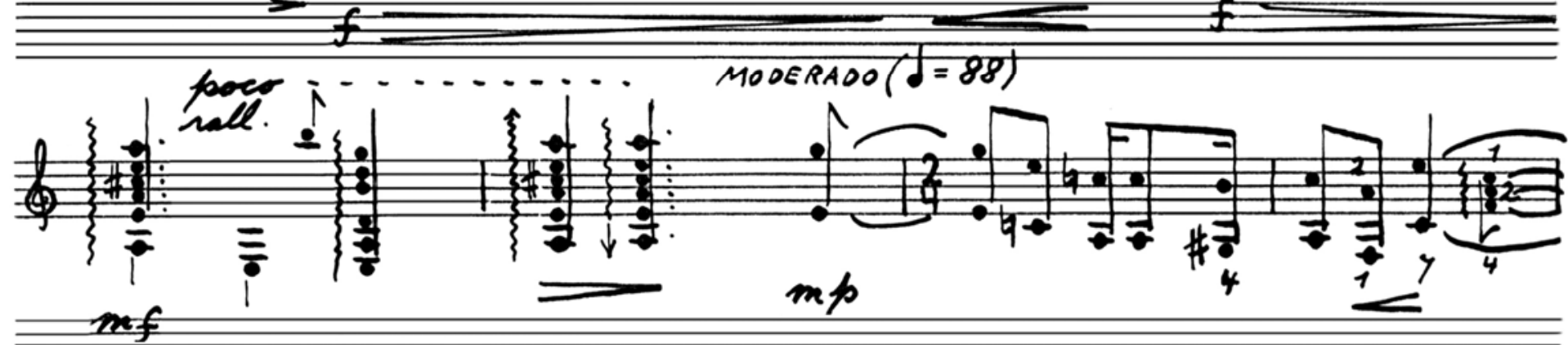

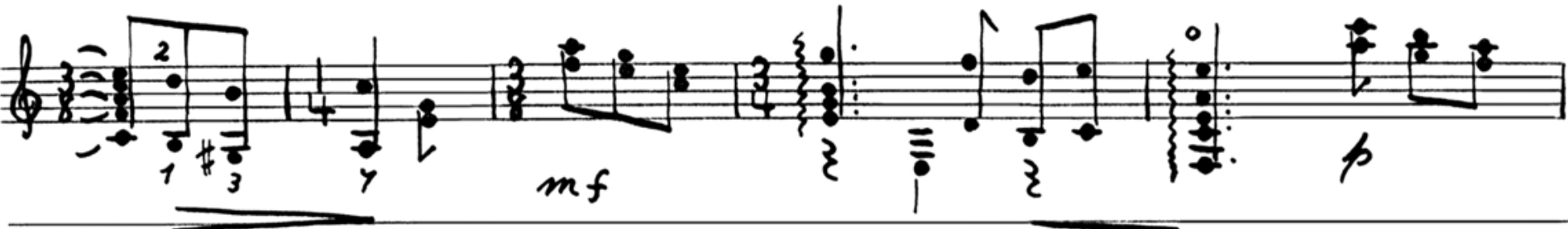

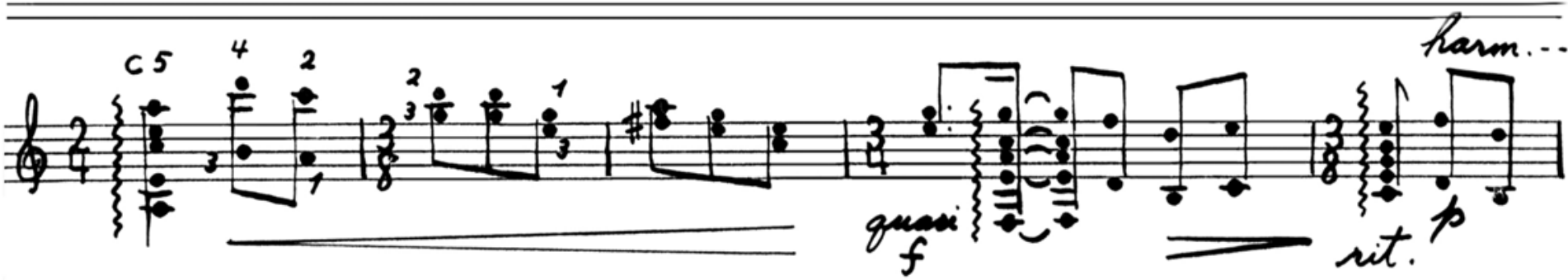


$\underbrace{}_{i}$

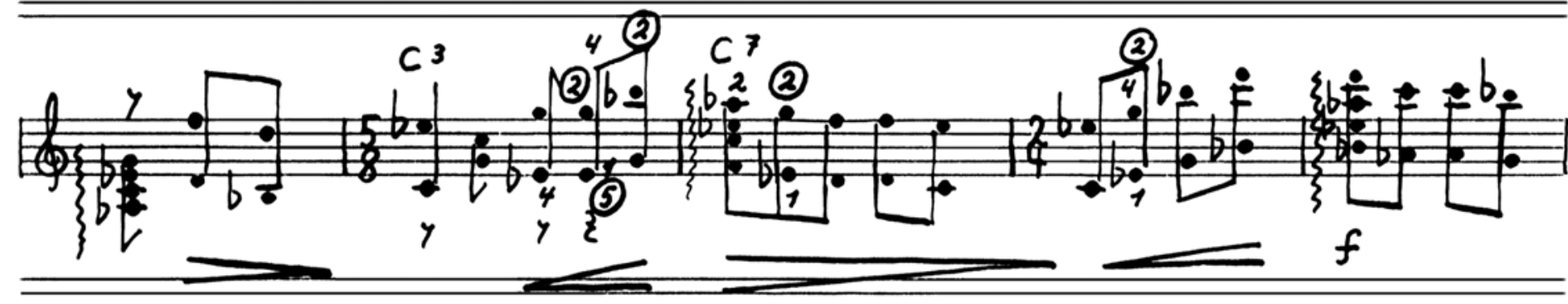

(3) -

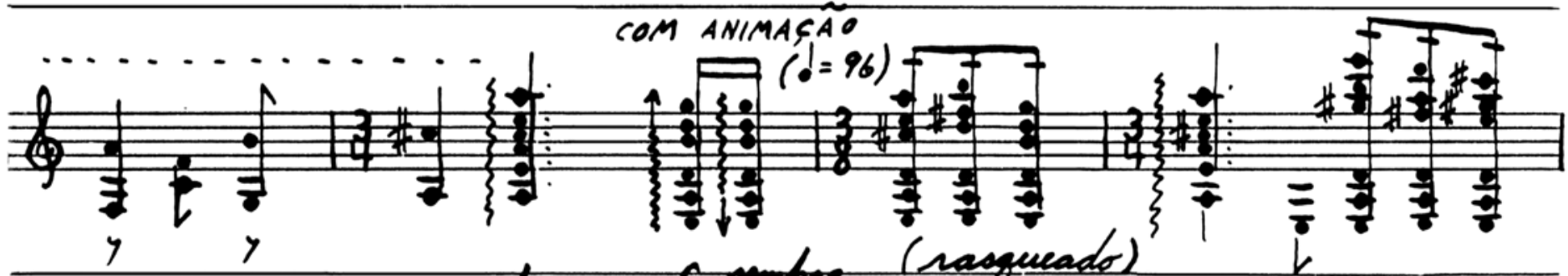

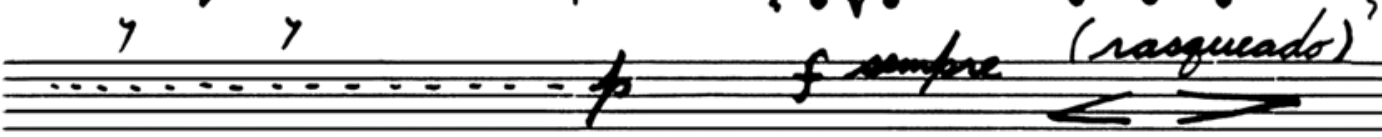

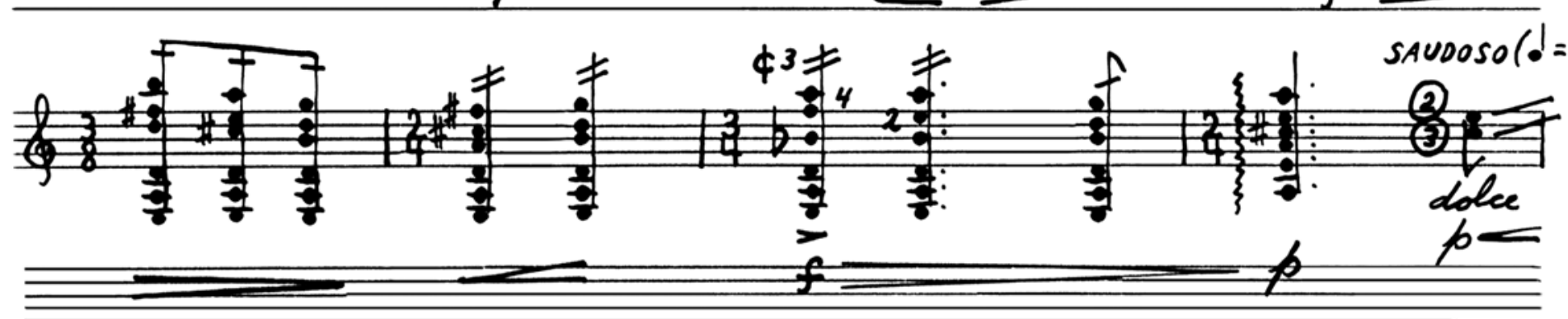
D- =

tharom. 25

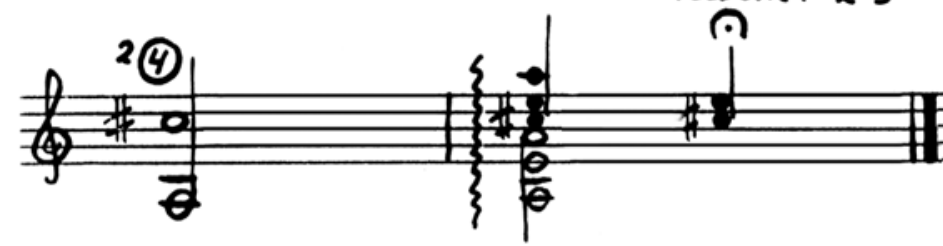

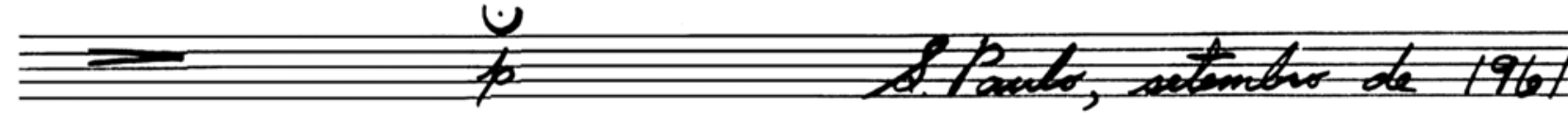


$y^{3}$

"As Alidivon" (3.
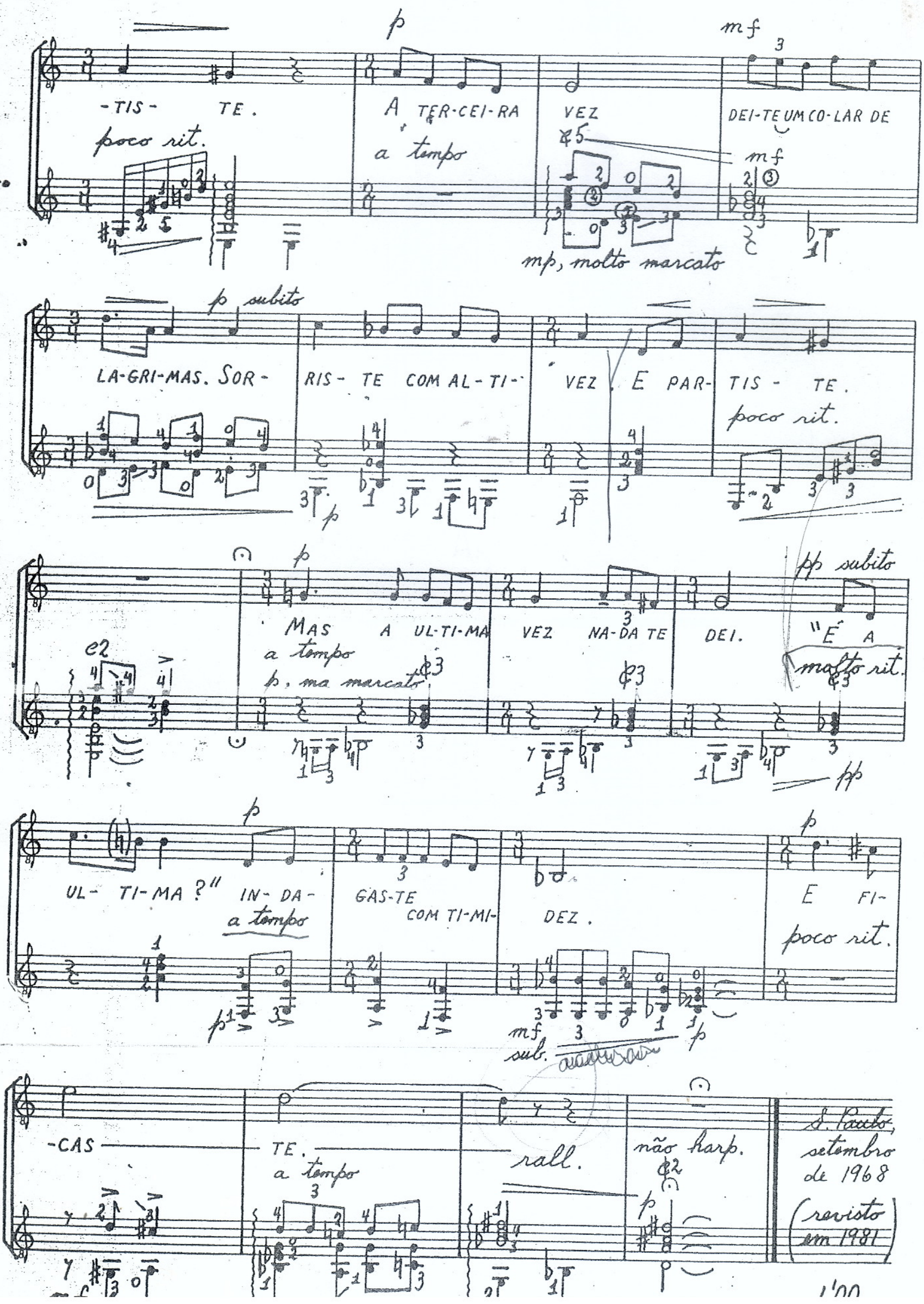
"Cls Lladivas"

Noxto de

(canto e violão)

Guilherme de Almeida

Covaldo taceridá

(1968)

$\frac{1}{4}$

Dighagä:- Hentique HNTO

.
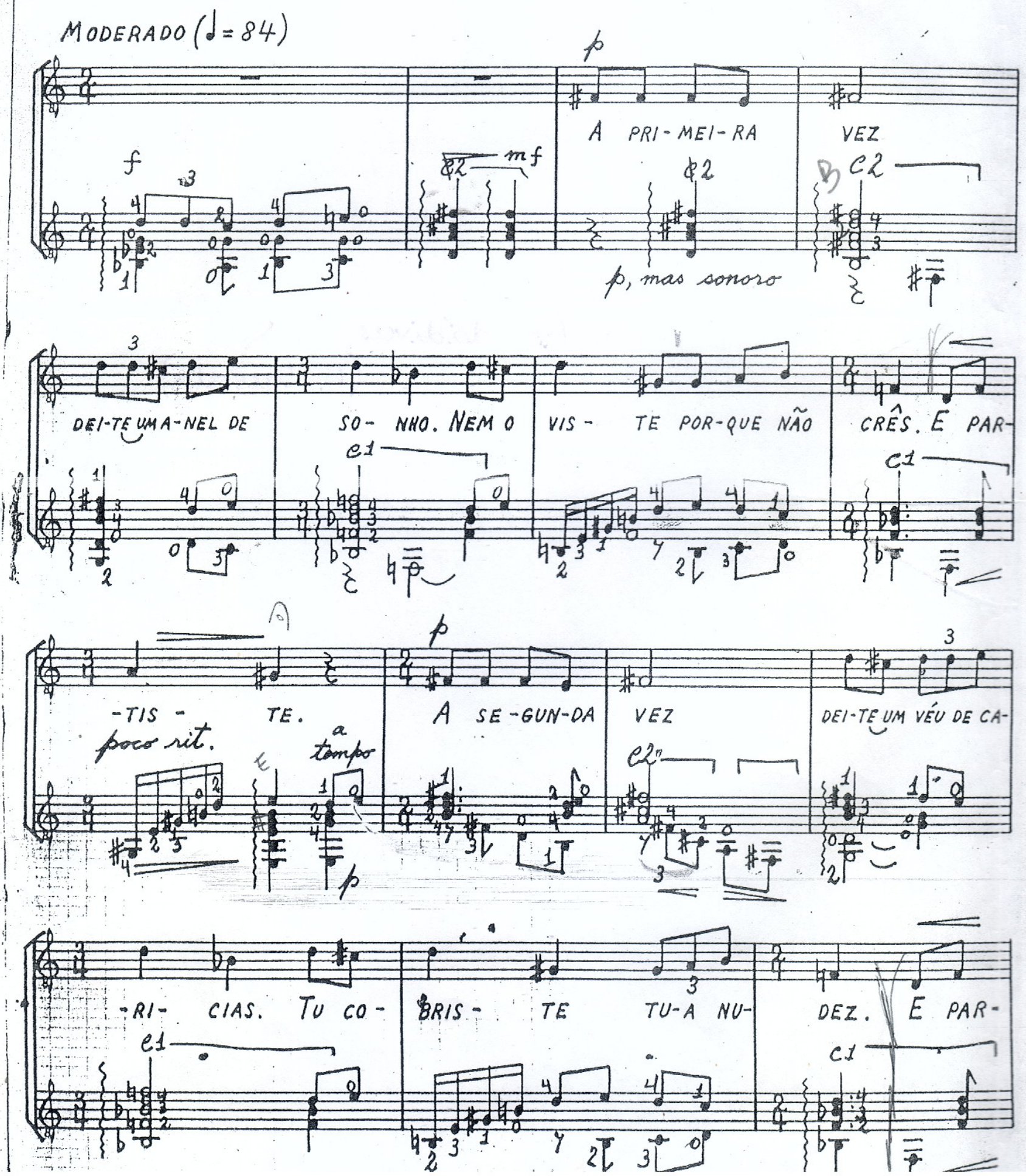

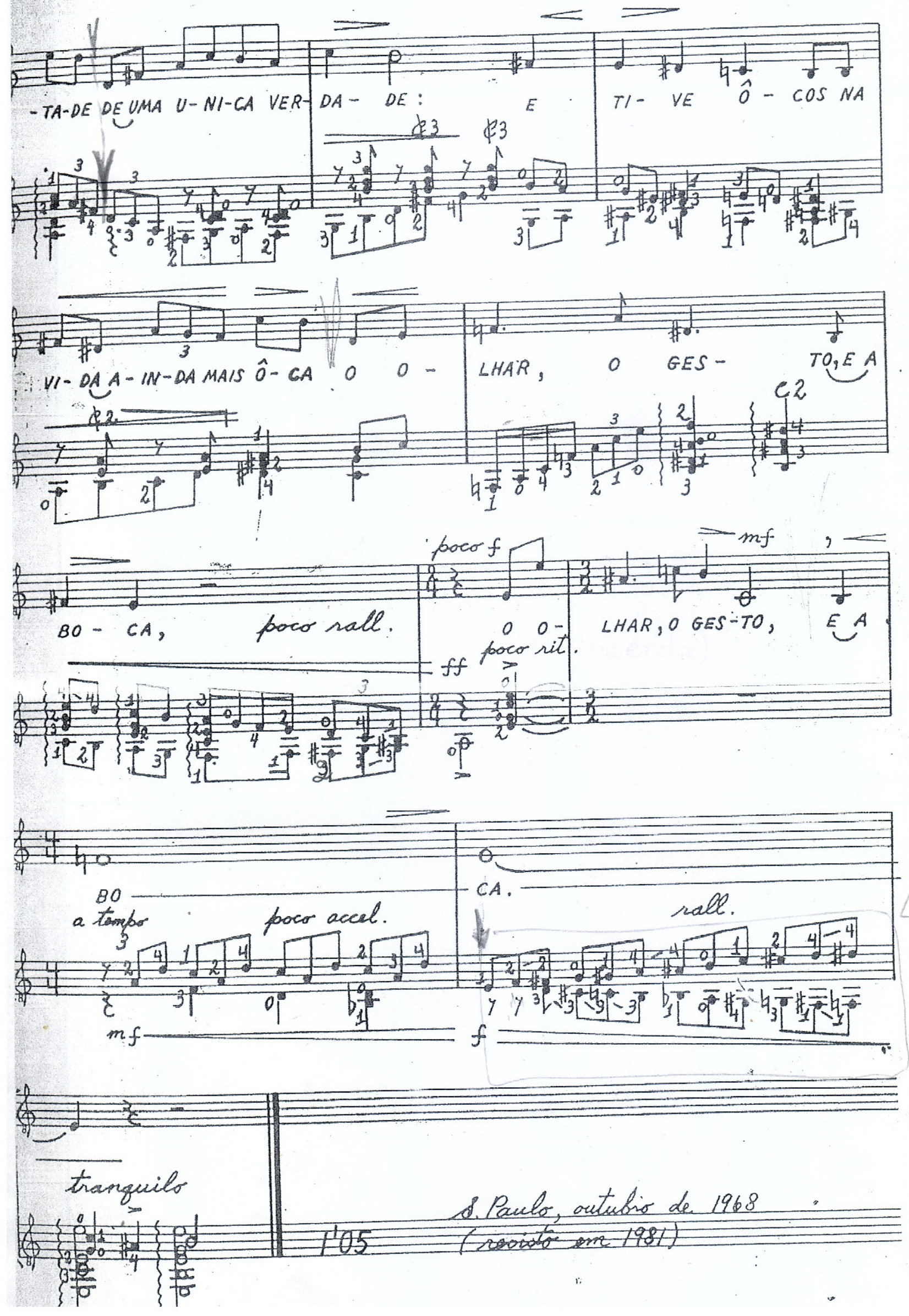


\section{"VEacur" \\ (canto e violão)}

Texto de

Guílherme de Almetia

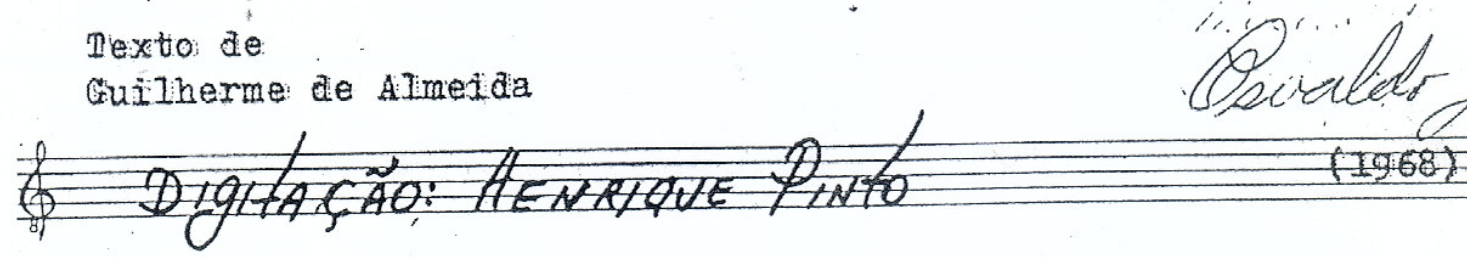

3

क

MODERADO $(d=84)$

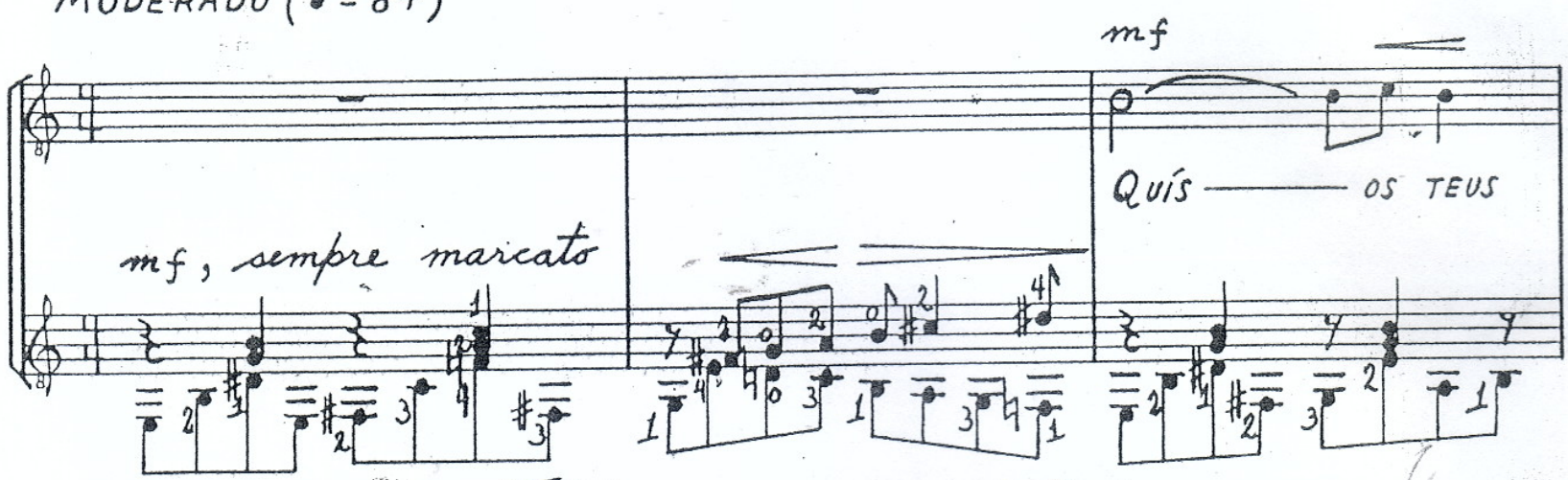

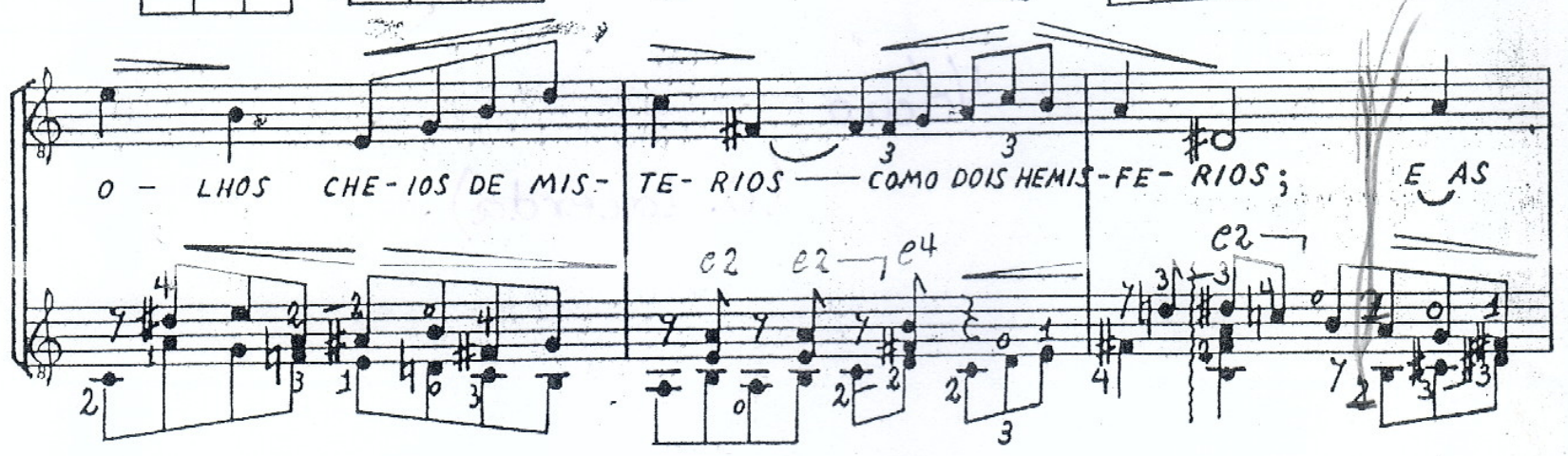

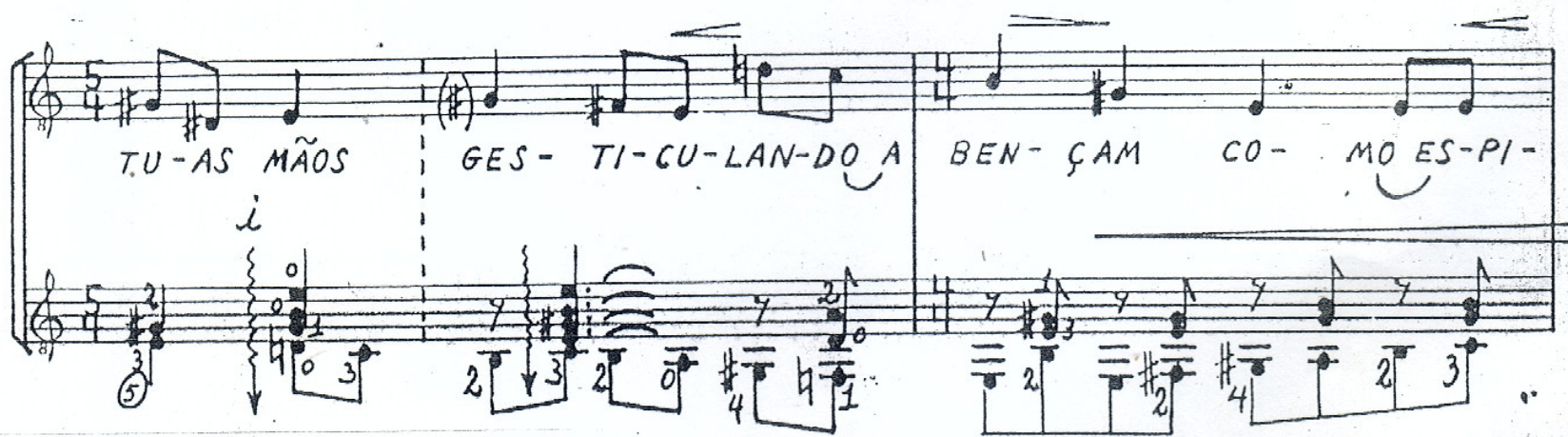

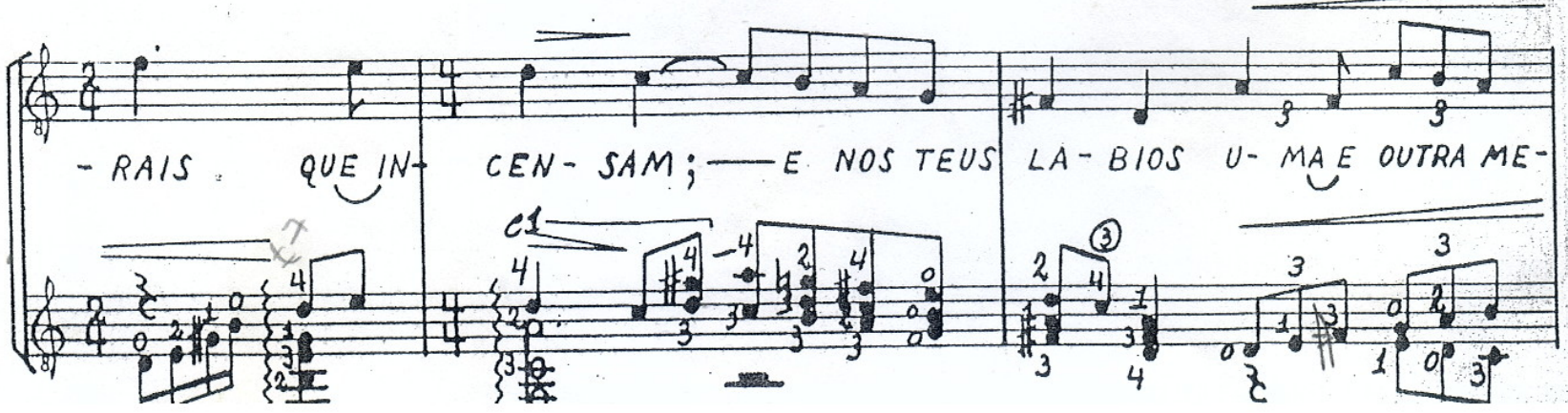




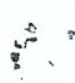

"Goudade." (4


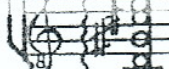

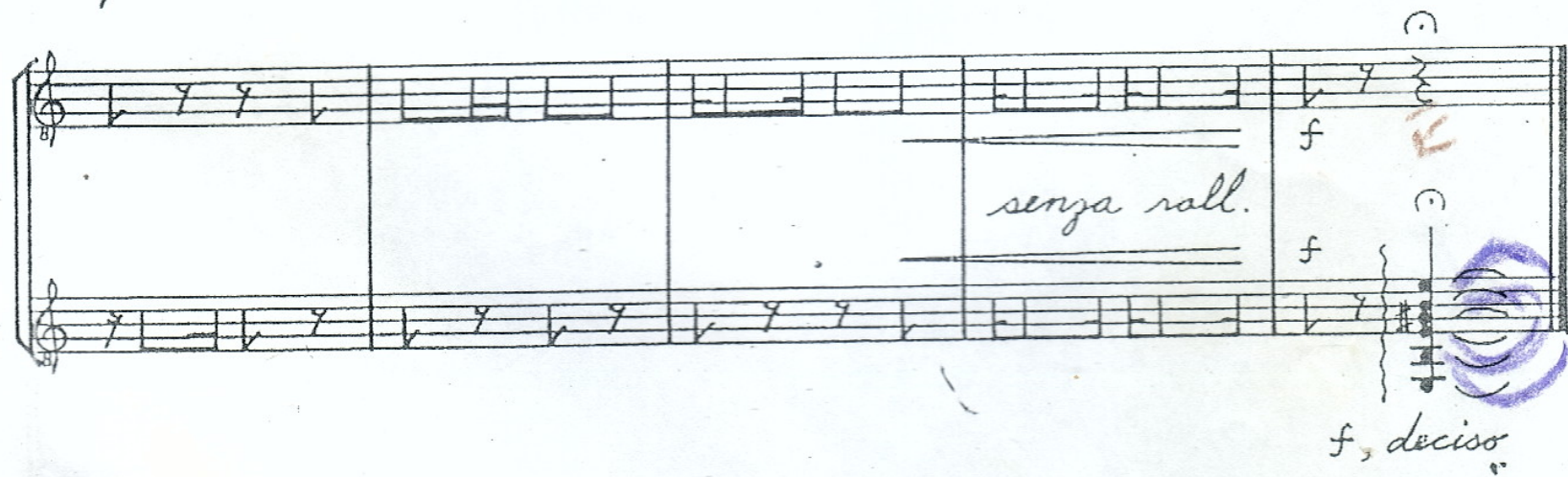

存

8. Paulo, outubro de 1968

(revisto $\mathrm{cm} \mathrm{1981)}$ 


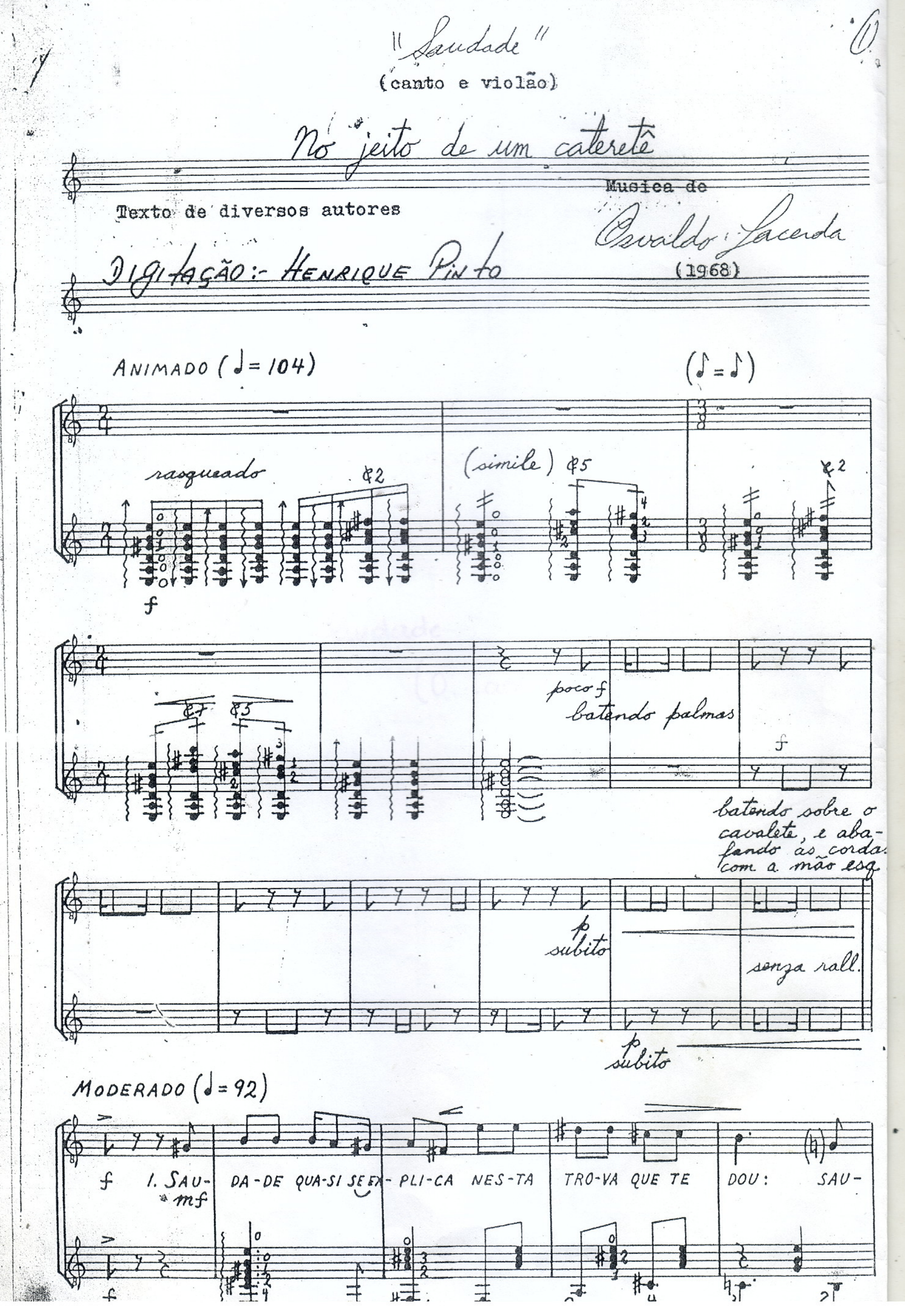




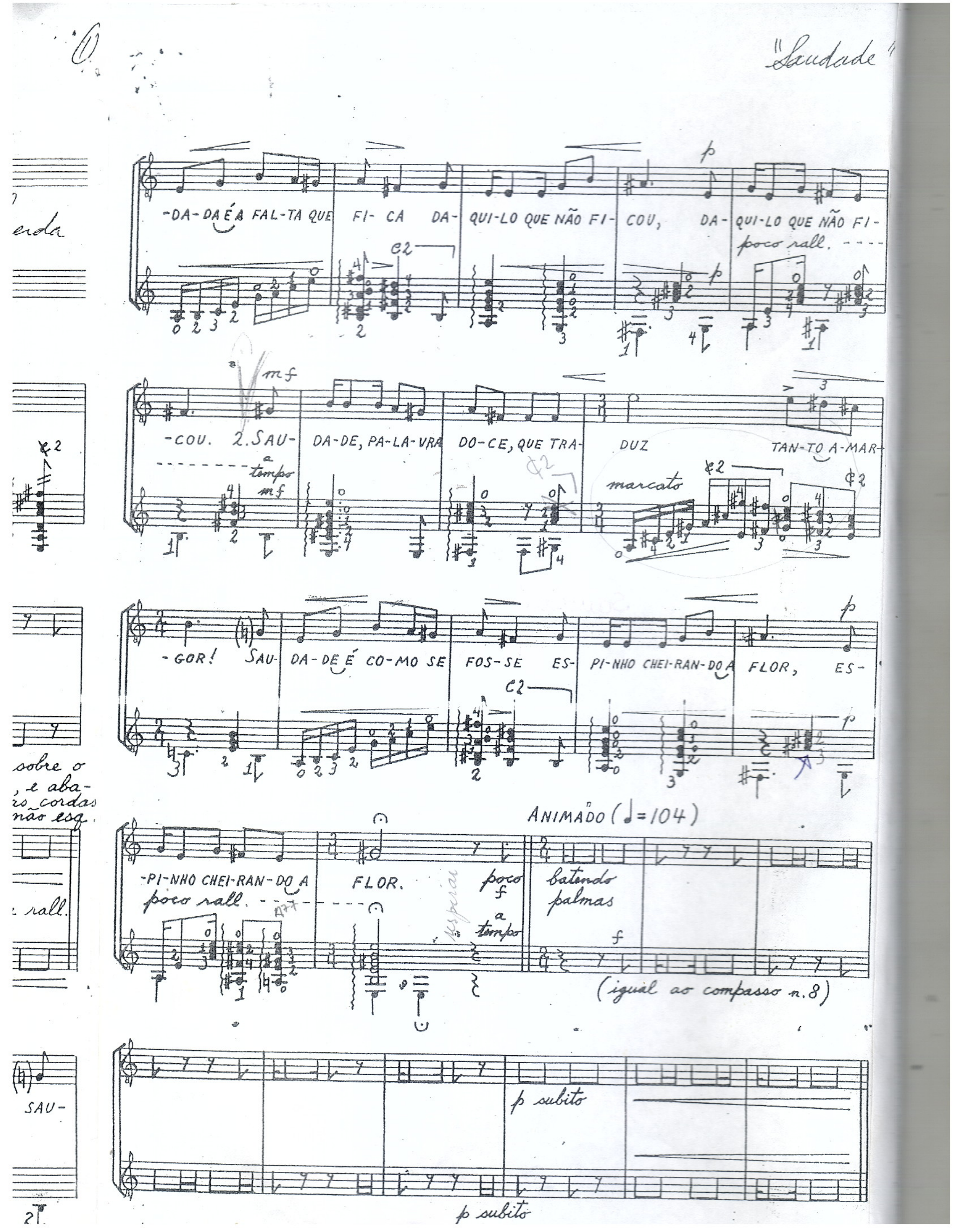


MODERADO $(d=92)$
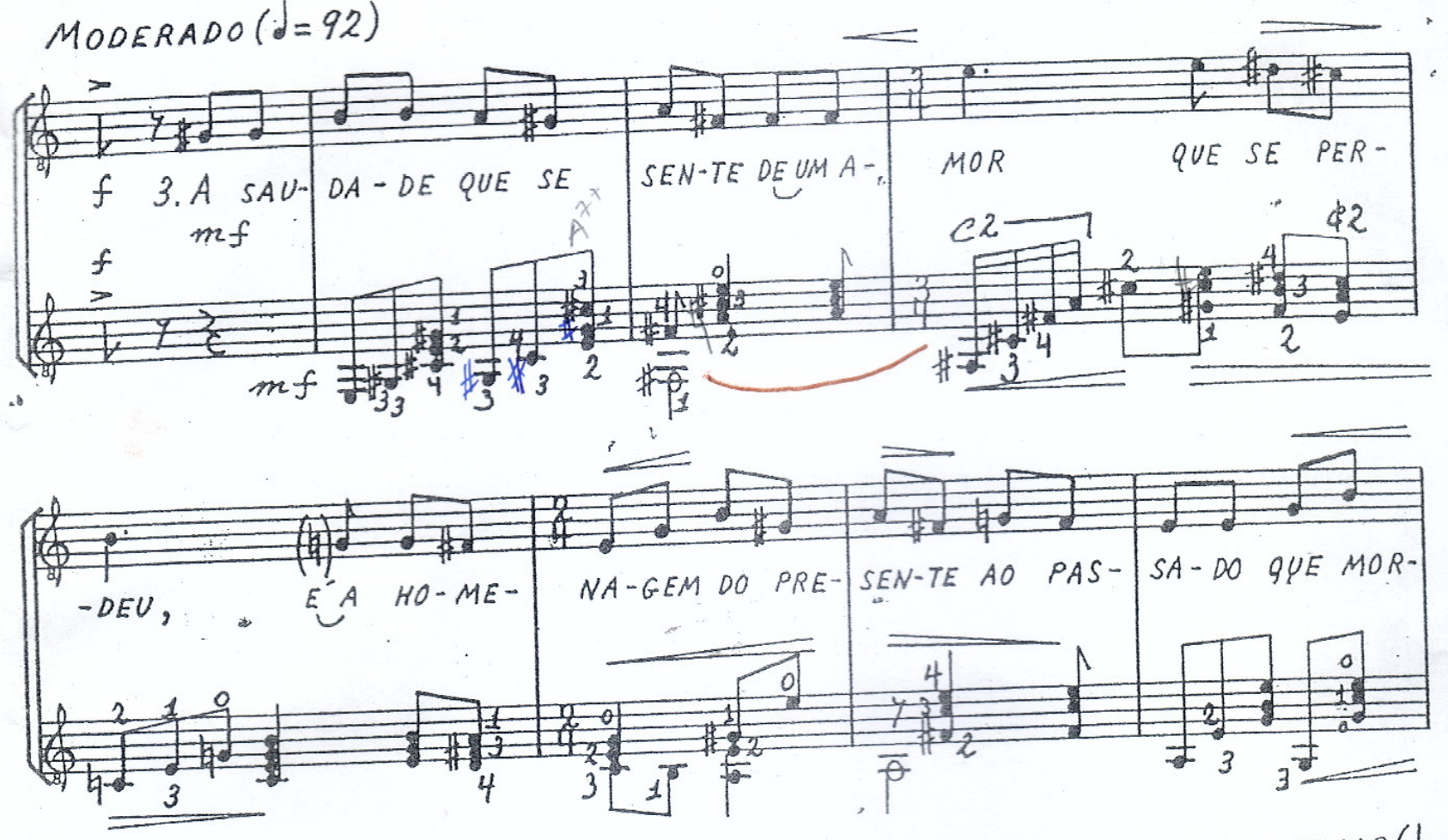

UM POUCO MAIS DEVAGAR $(\mathrm{d}=84)$
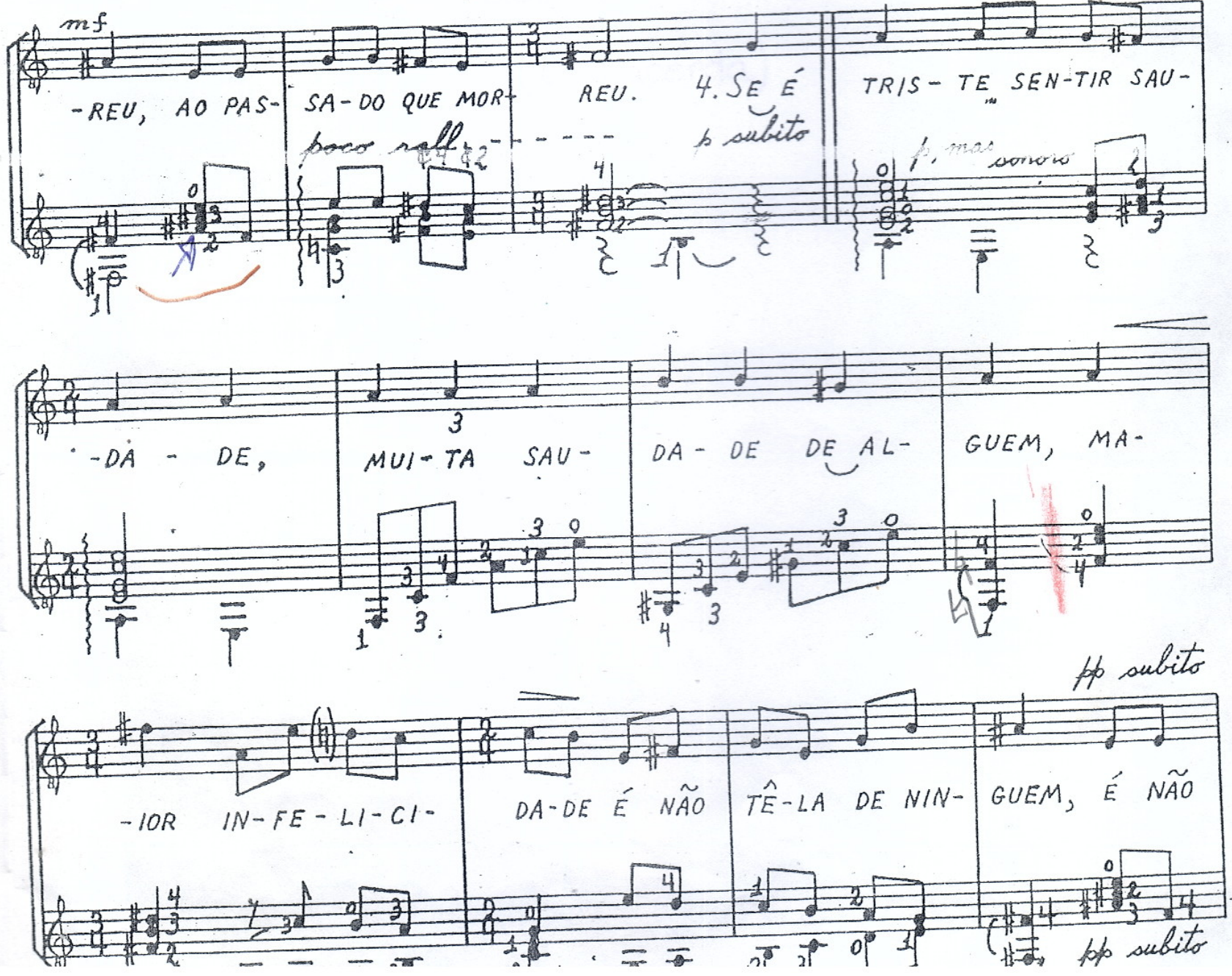


\section{Cantilena}

Andante non Troppo lento, ma sostenuto $d=72$

Osvaldo Lacerda

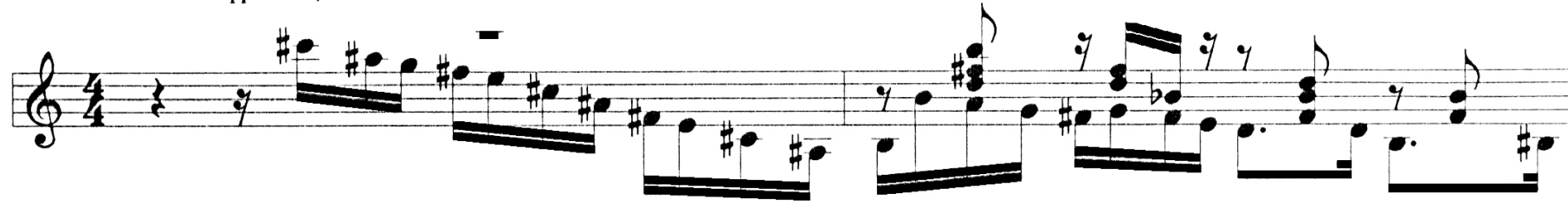

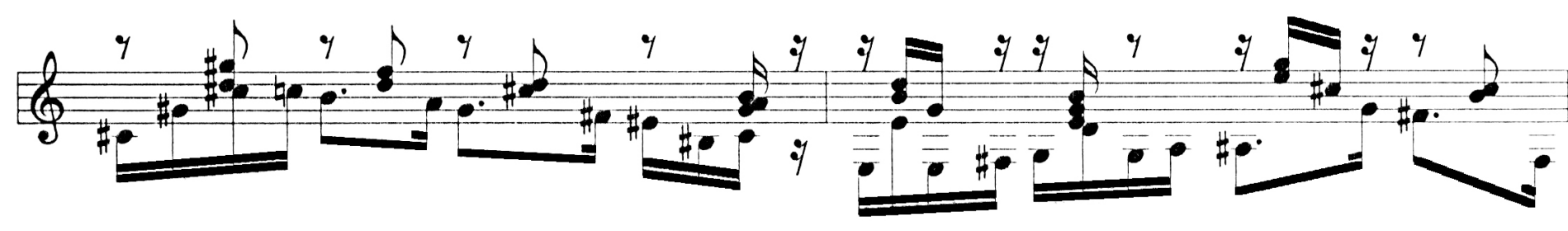

६

$\oint_{\# 0}^{4}$

(3)

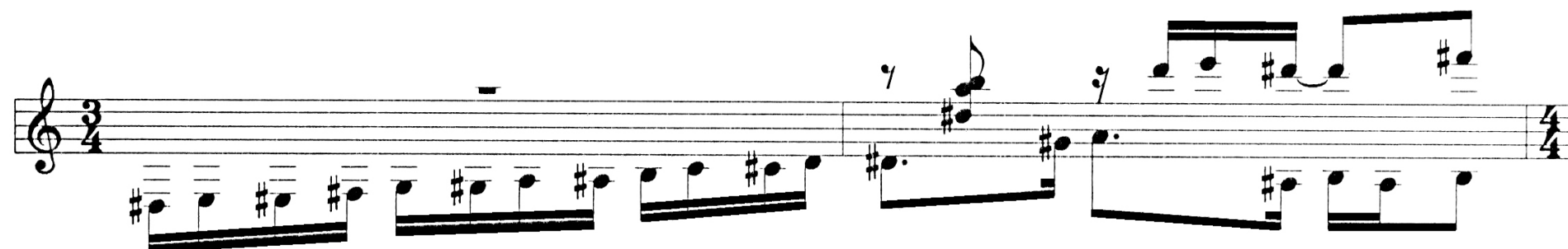

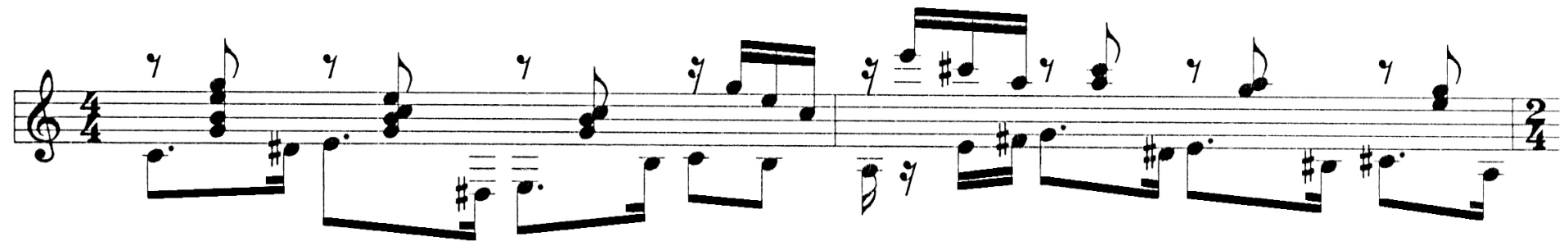


15

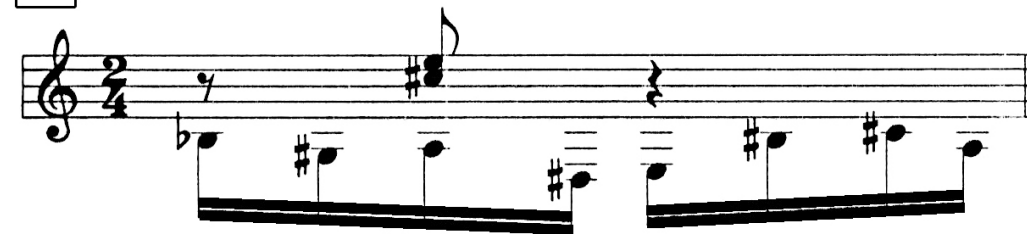

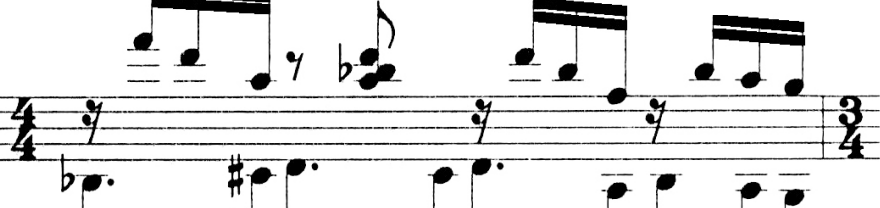

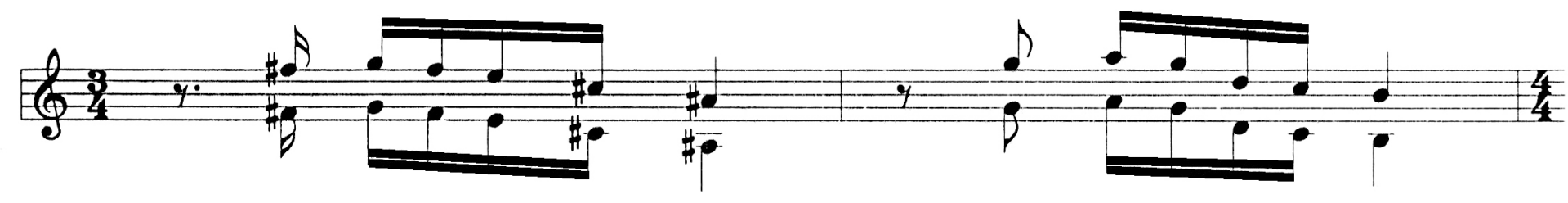

(9) 4

(6)

Q

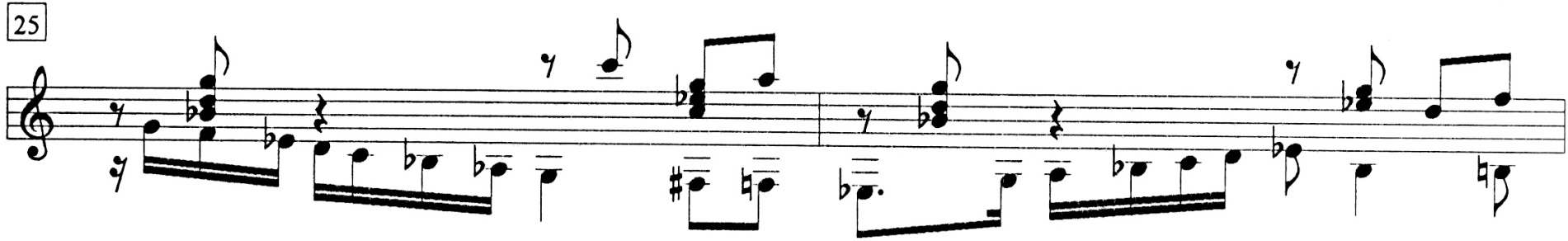

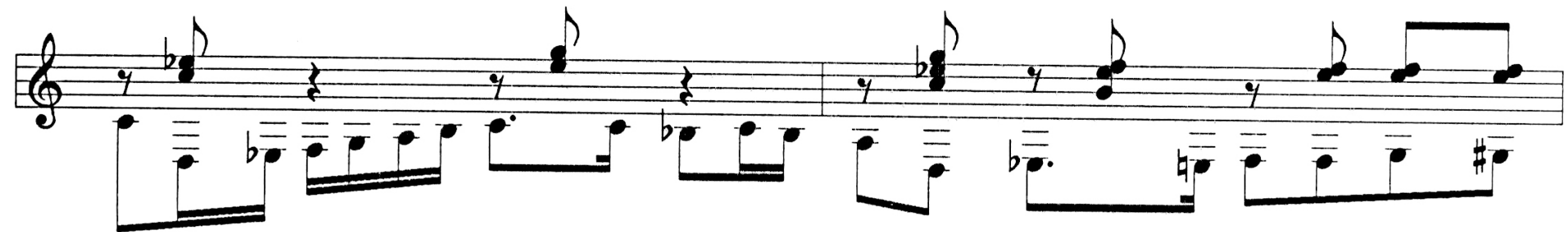

"Cantilena" (2) 

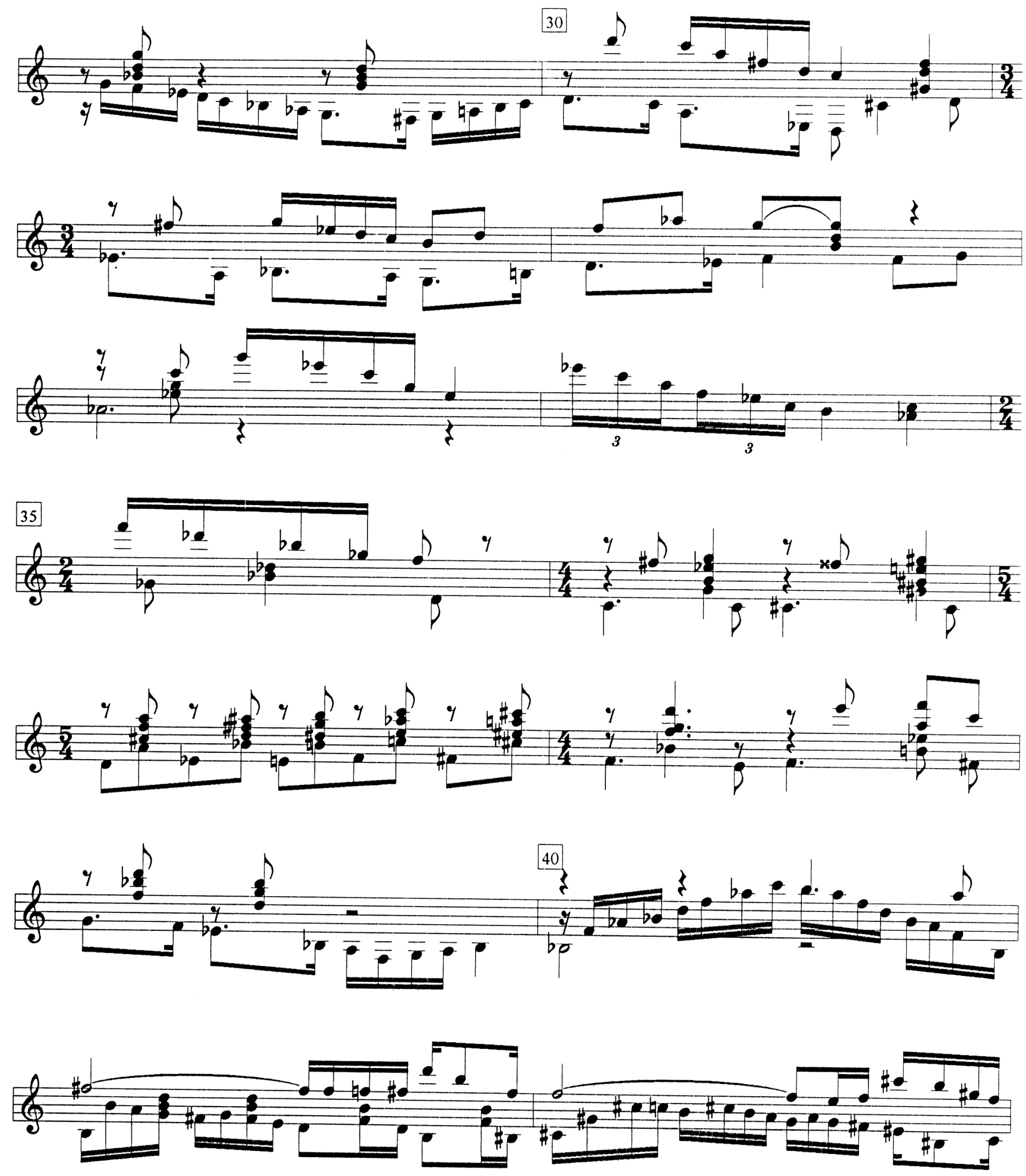

$$
\text { "Cantilena" } 3
$$




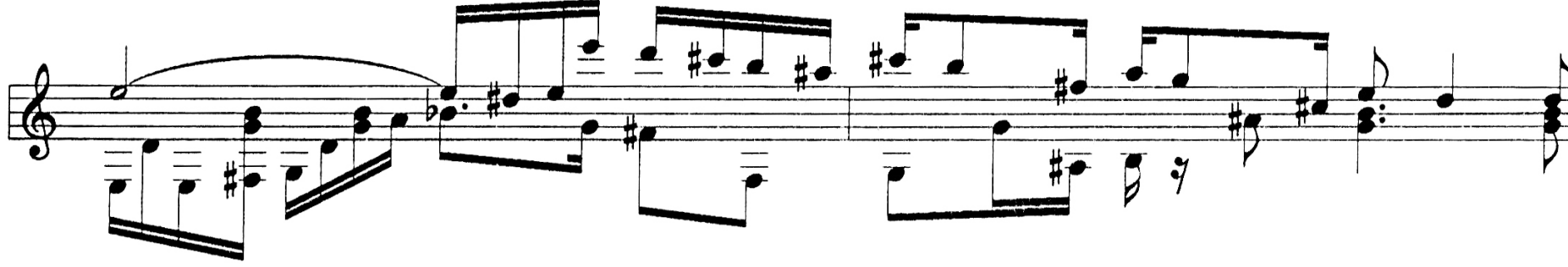

(Q)

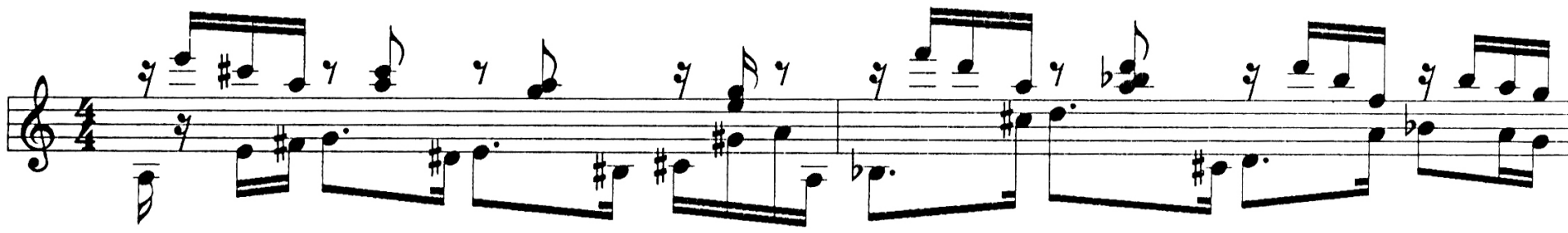

Q6

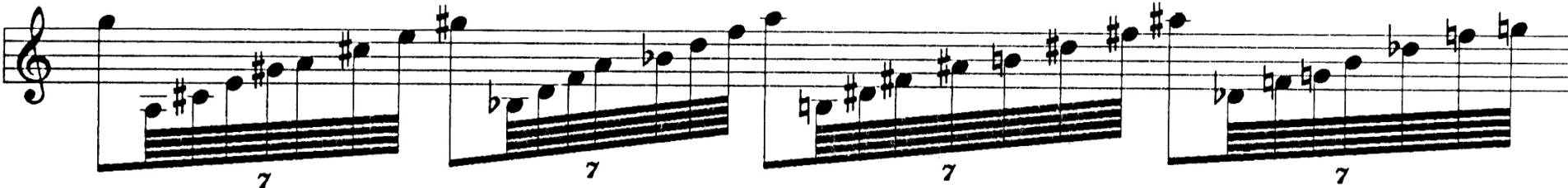

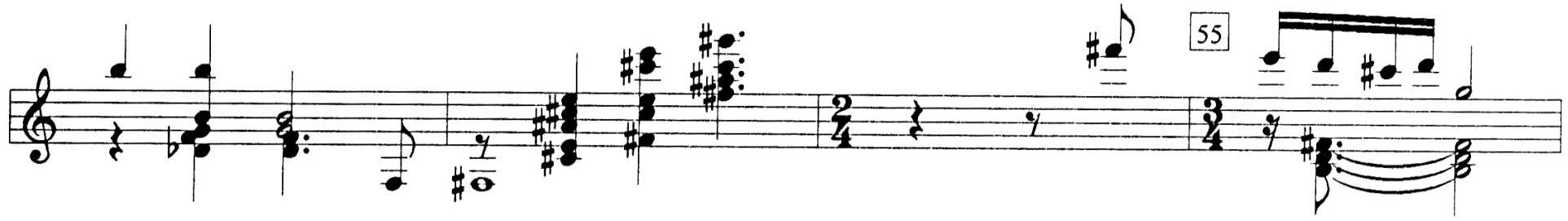

Q(2)

El

"Cantilena" 

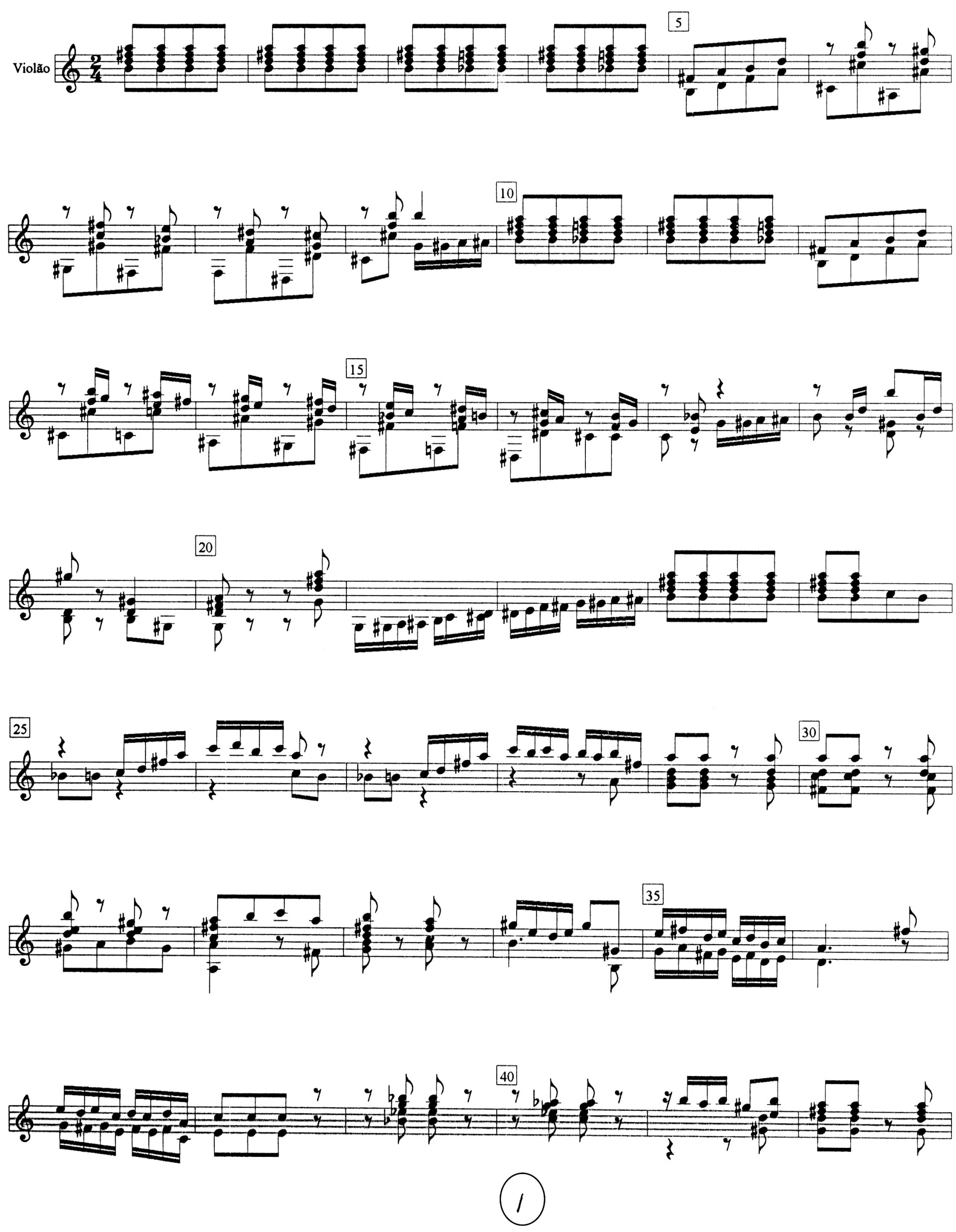
45

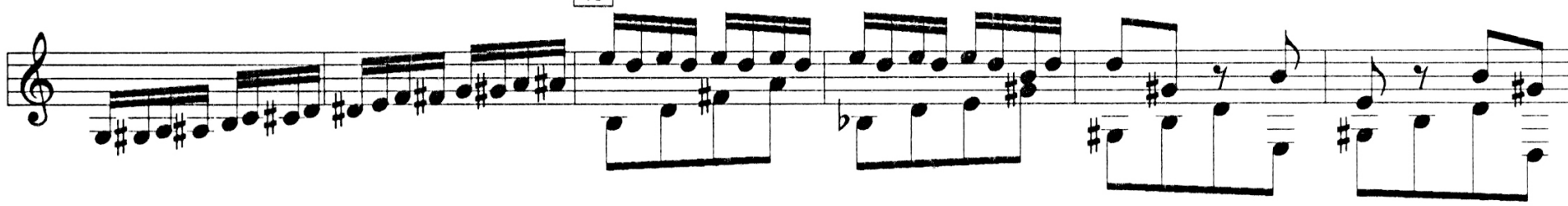

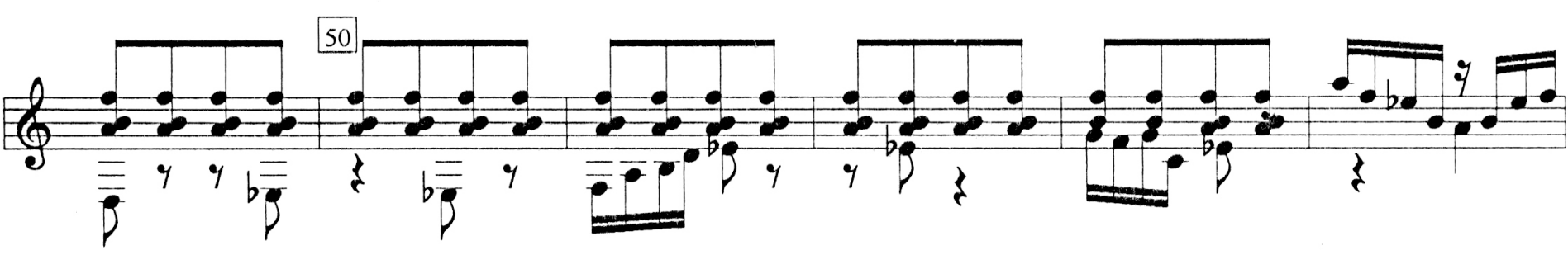

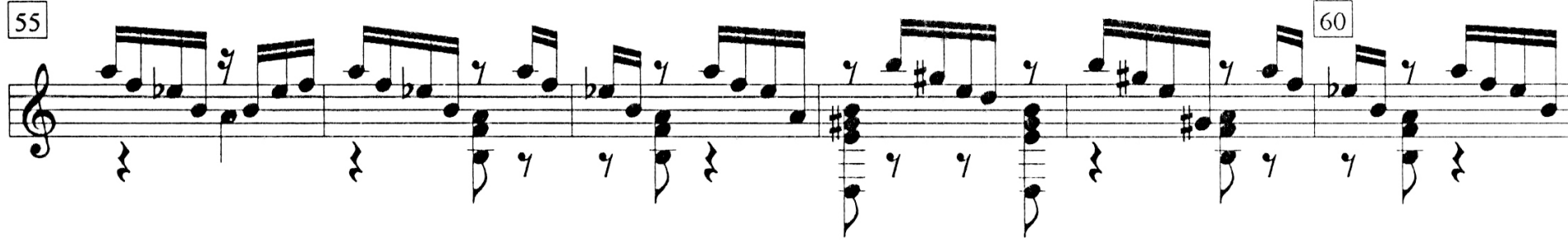

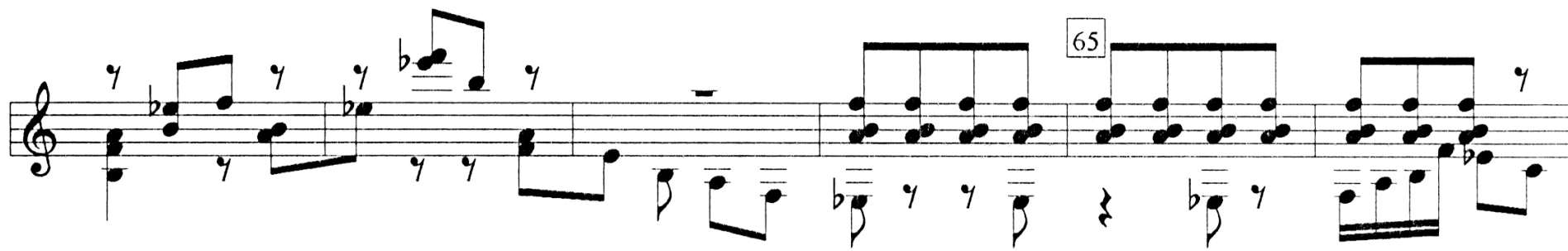

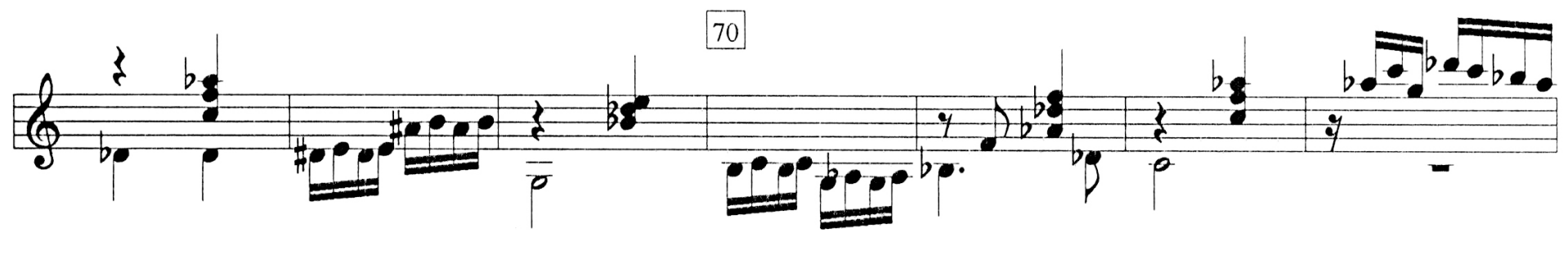
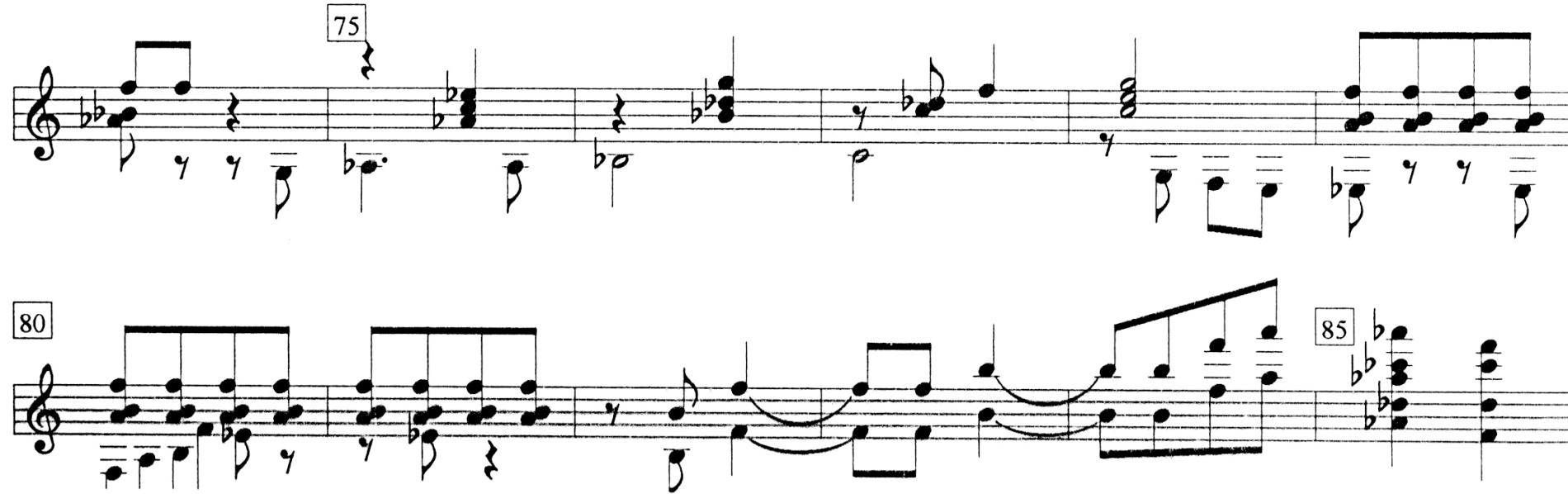

"accatina"

(2) 
and
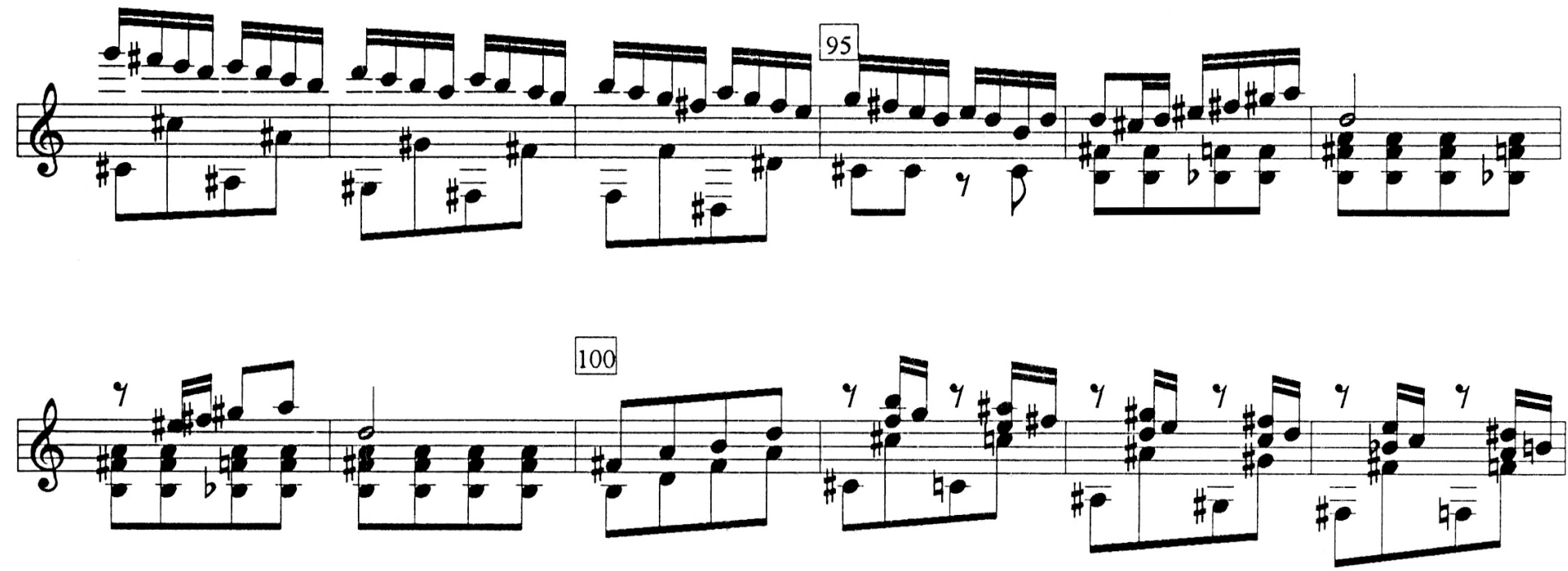

(6)
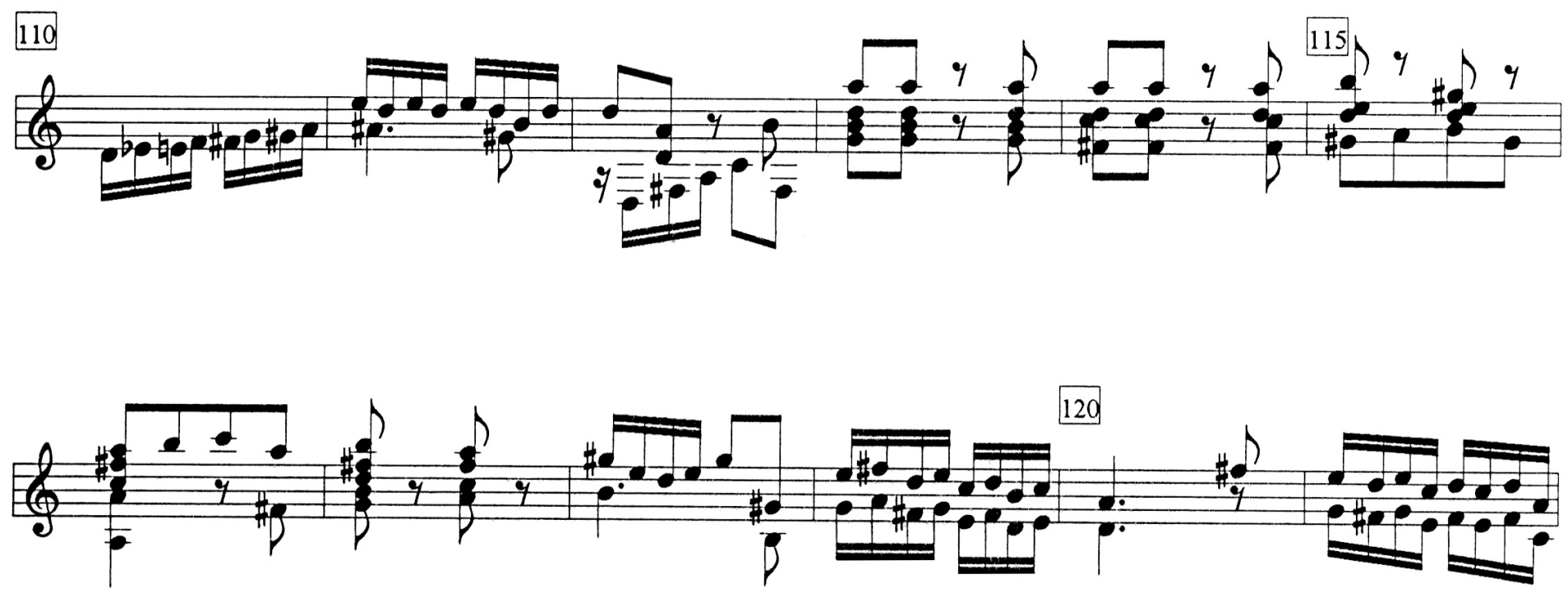

"Loceatina" 

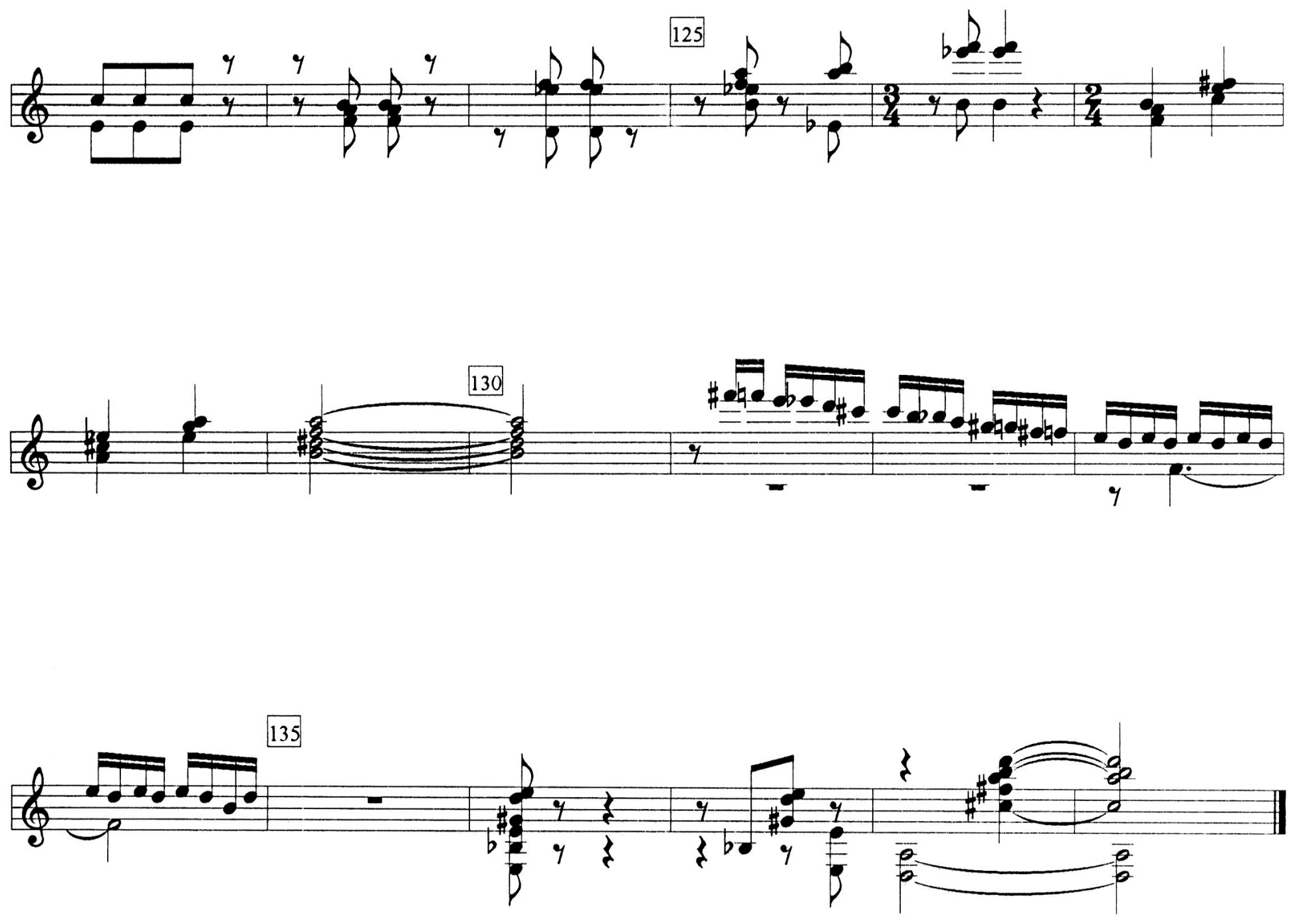

"Locatina" (4) 


$$
\text { "Poemeto" }
$$

Tranquilamente Movido $\quad d=66$

Osvaldo Lacerda

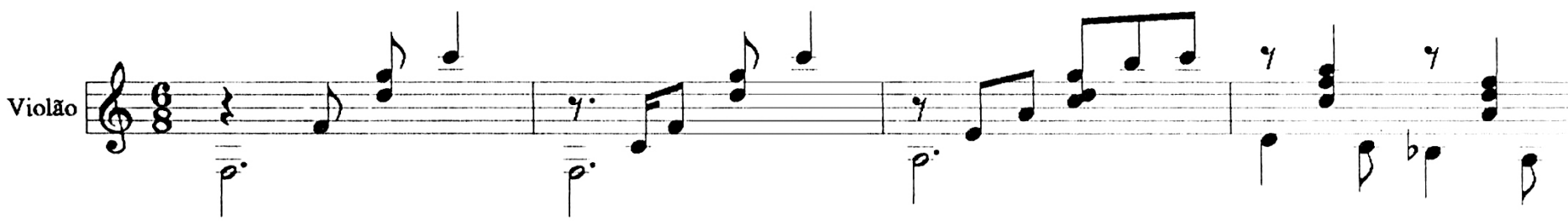

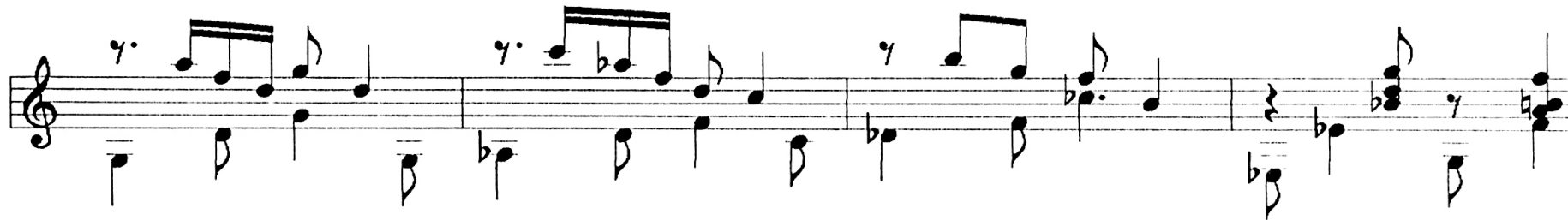

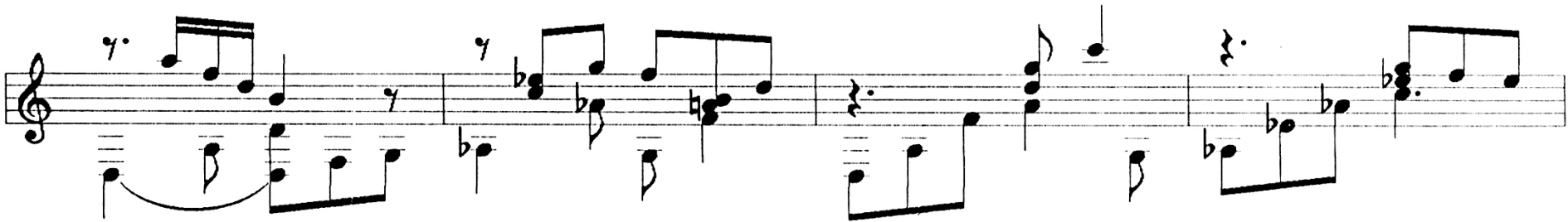

80
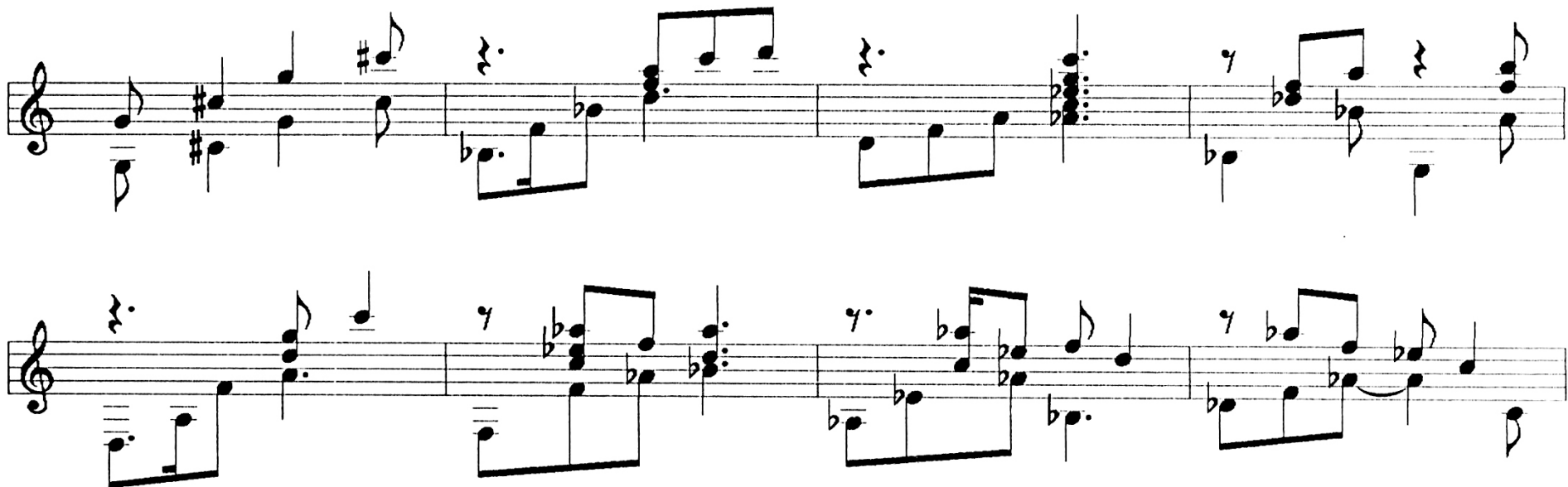

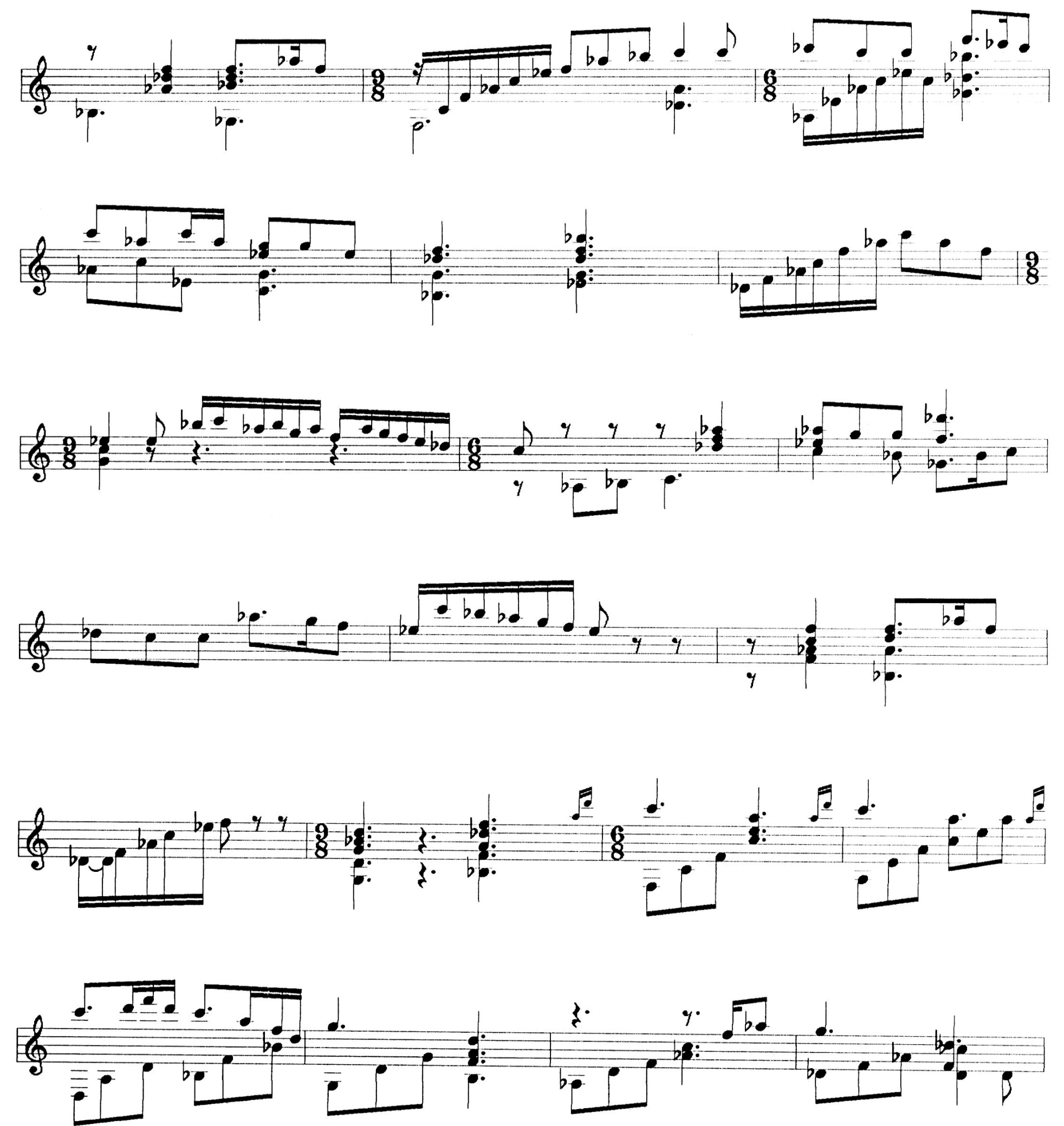

"Poemeto" 2 


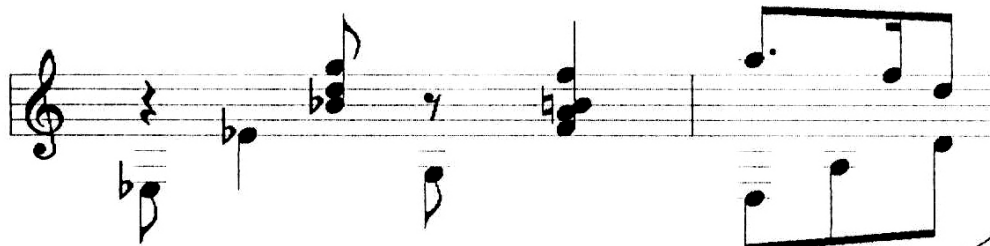

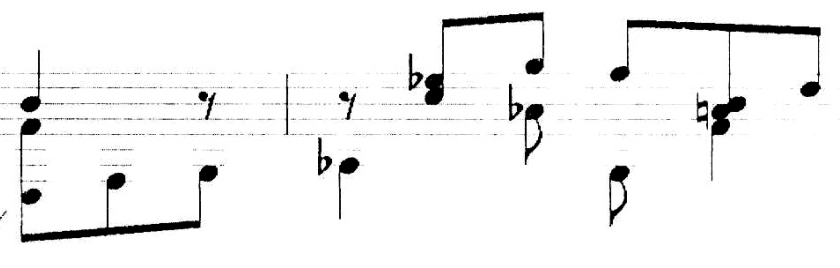

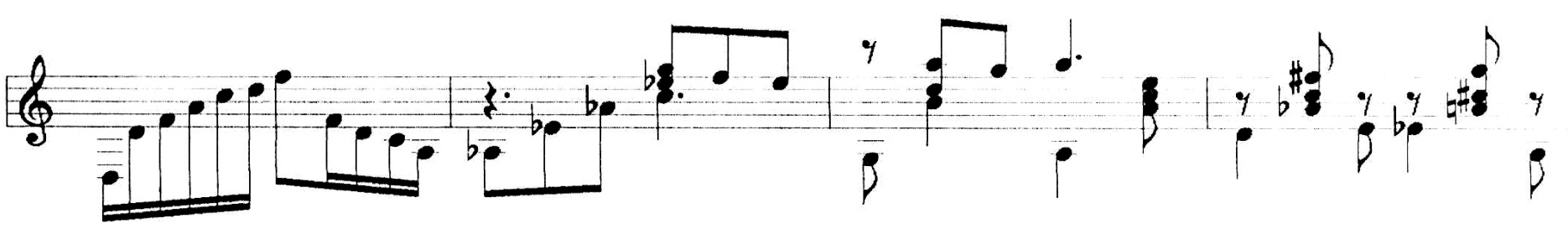

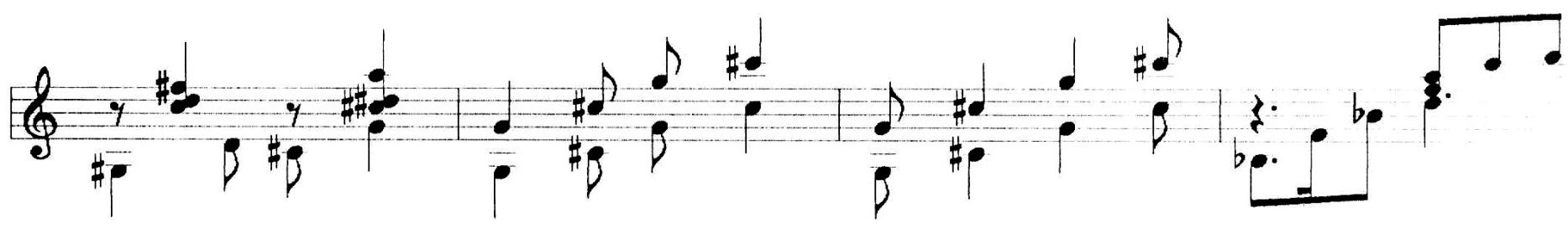

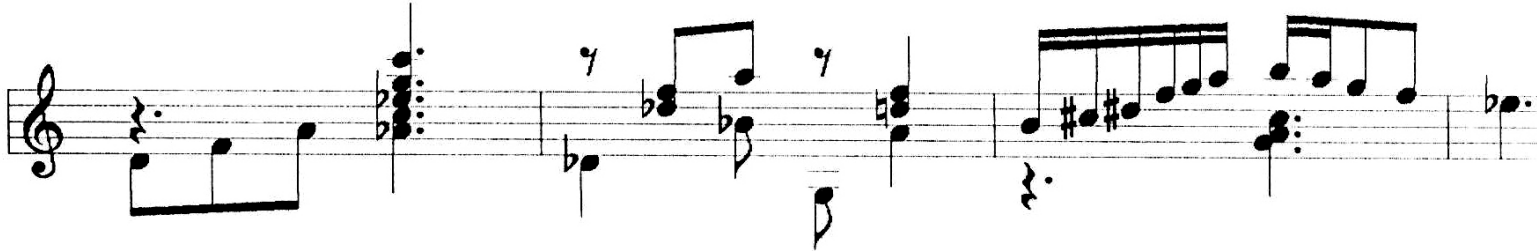

$\oint_{2} \%$ be

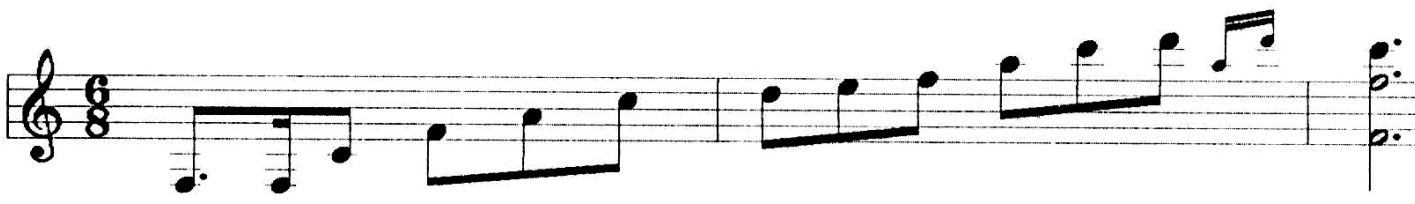

"Pometo"

(3) 


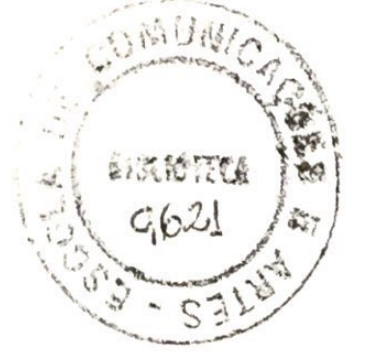

\section{CANTILENA}

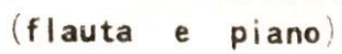

\section{Osvaldo Lacerda}

ANDANTE NON TROPPO LENTO,

MA SOSTENUTO $(d=72)$

FLAUTA

PIANO
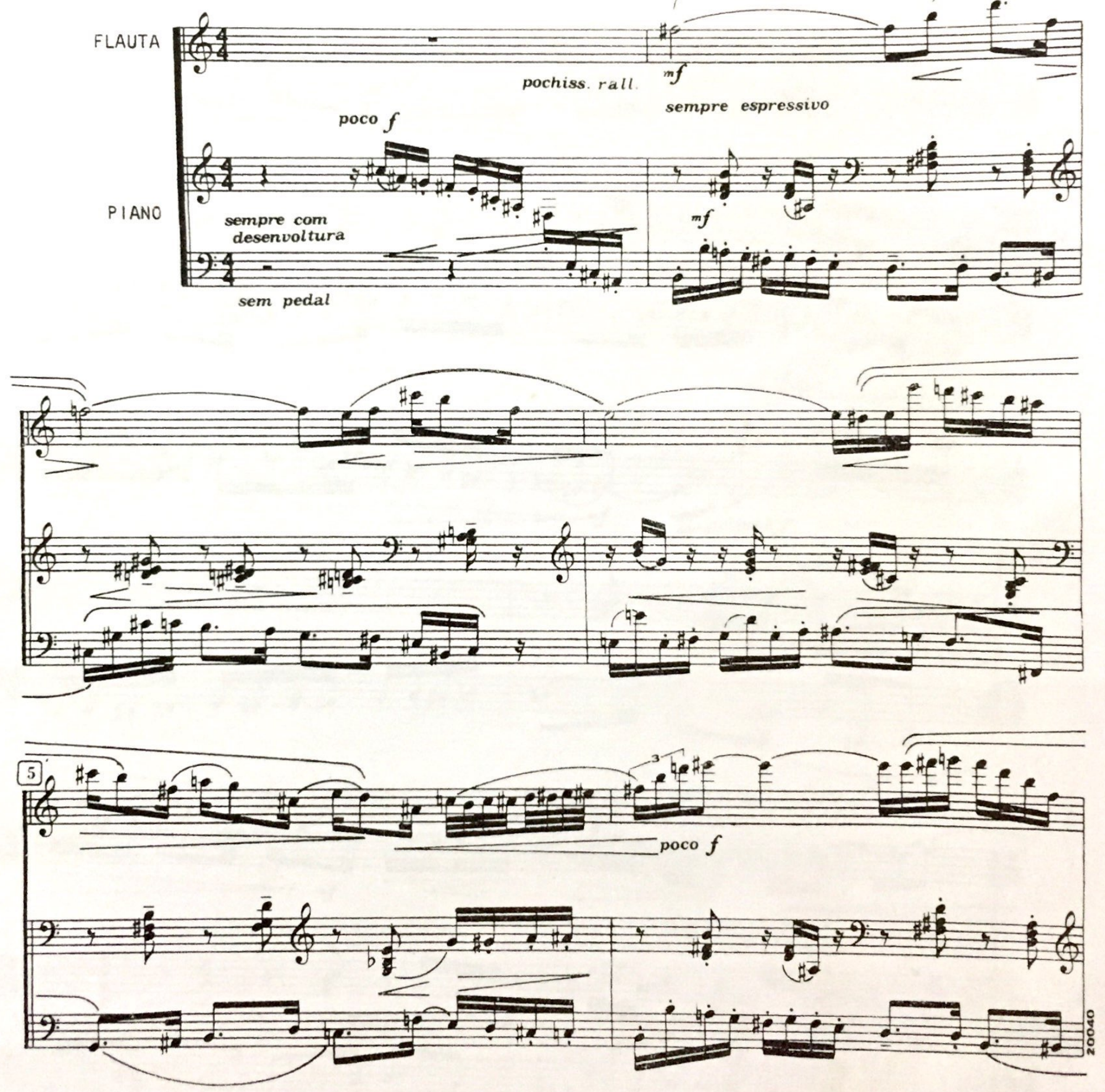

(C) Copyright 1987 by

EDITORA NOVAS METAS LTDA.

São Paulo $/ \mathrm{SP}=$ BRASIL

A11 rights reserved. 

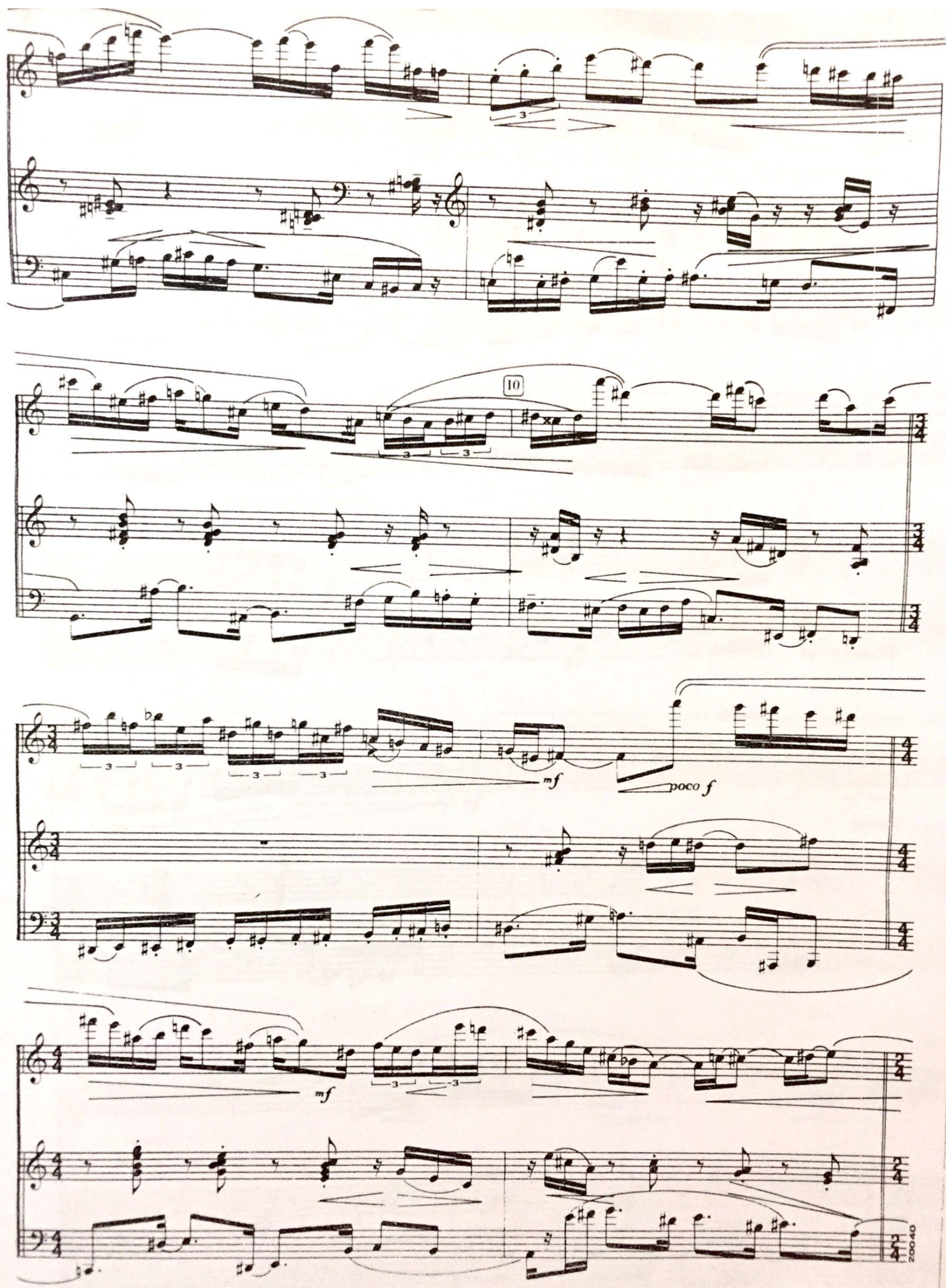


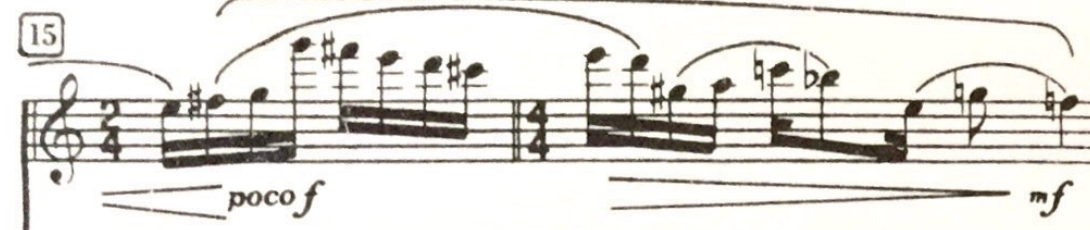

$+2$

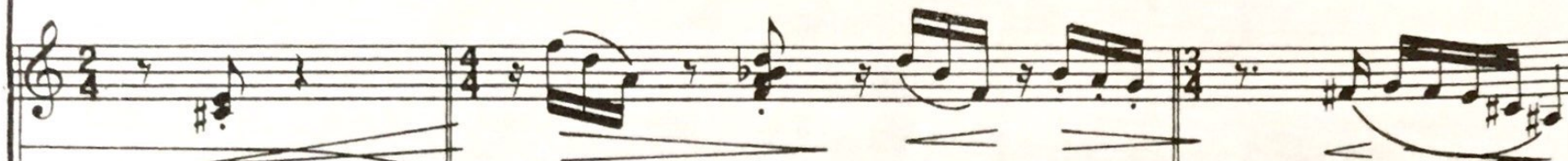

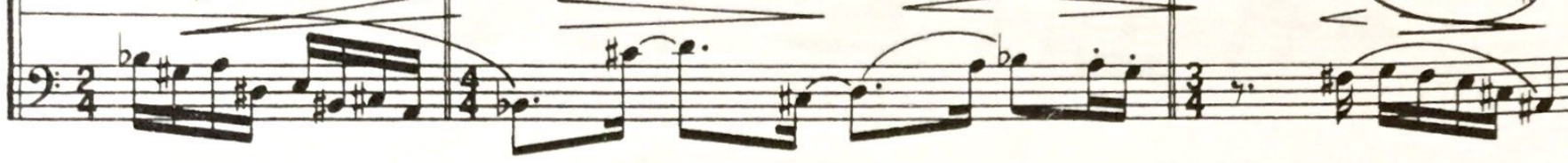

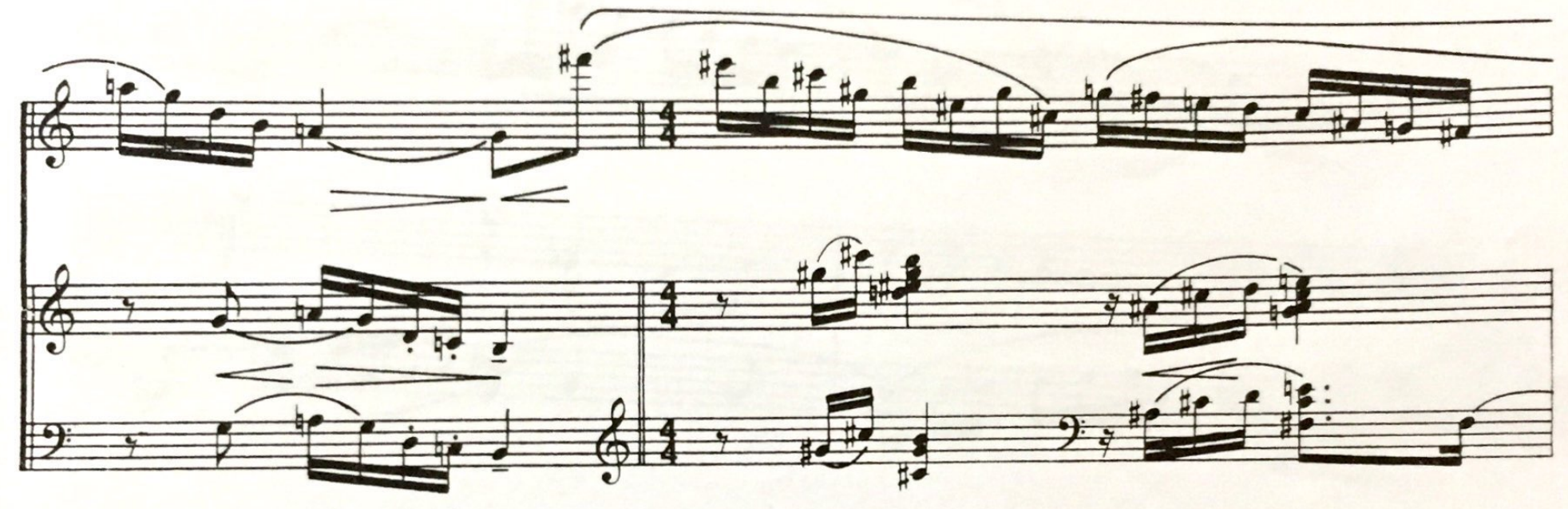

20
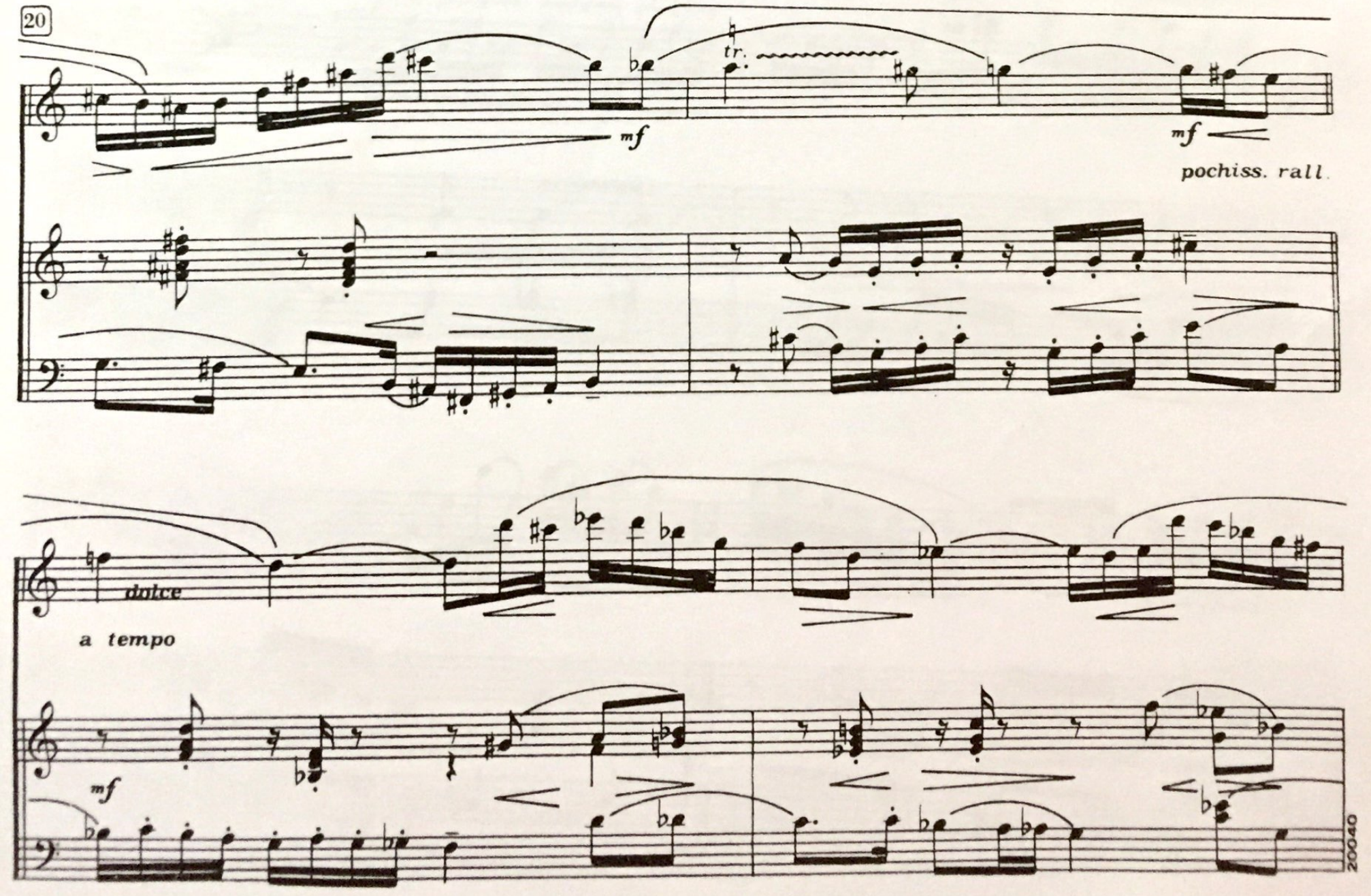

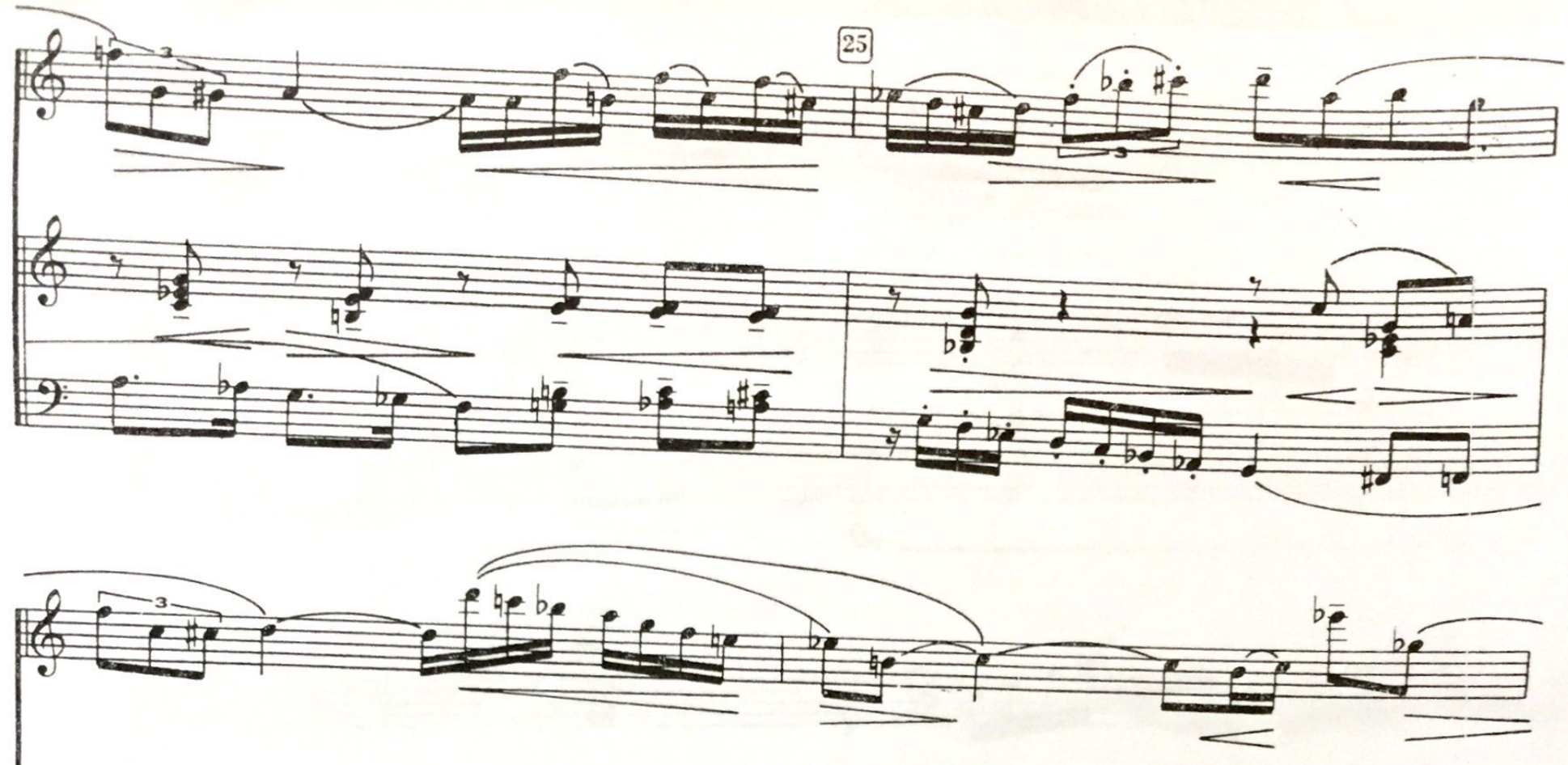

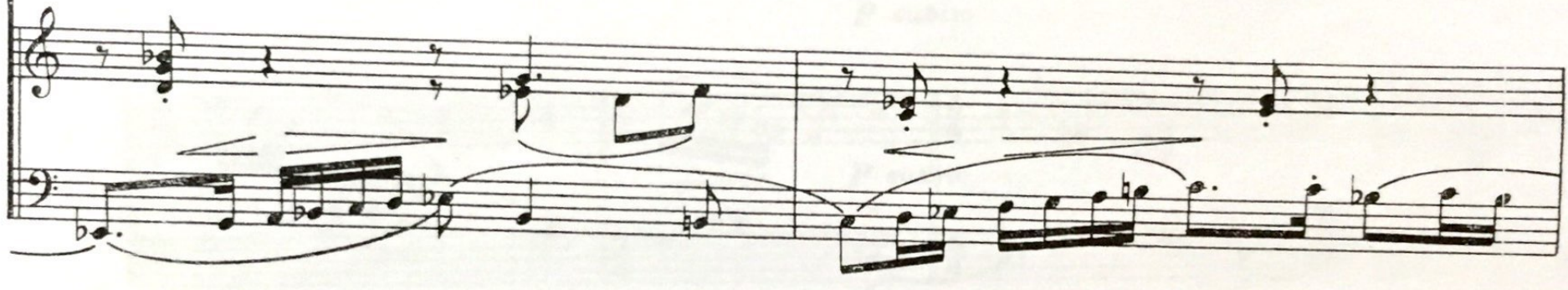

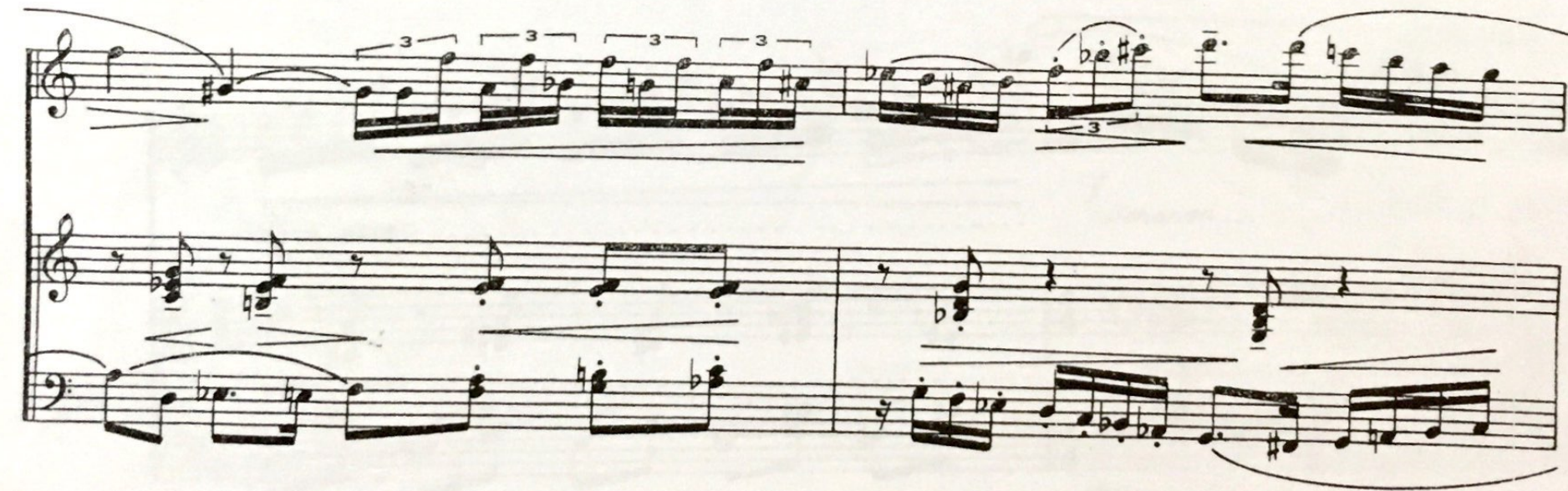

30

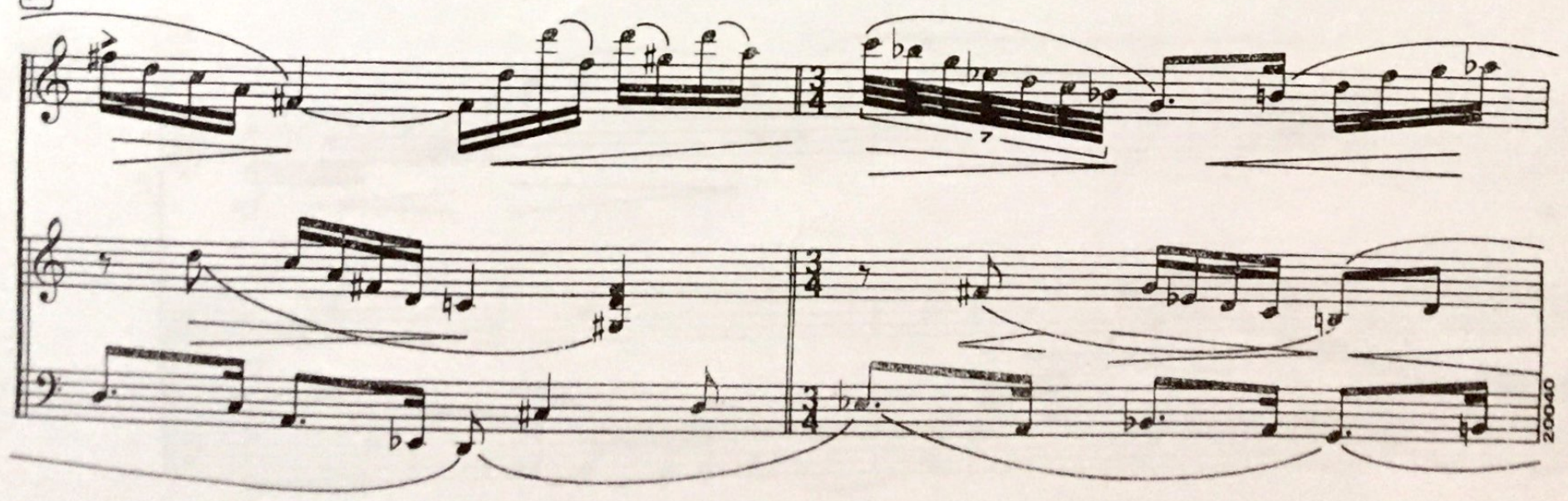




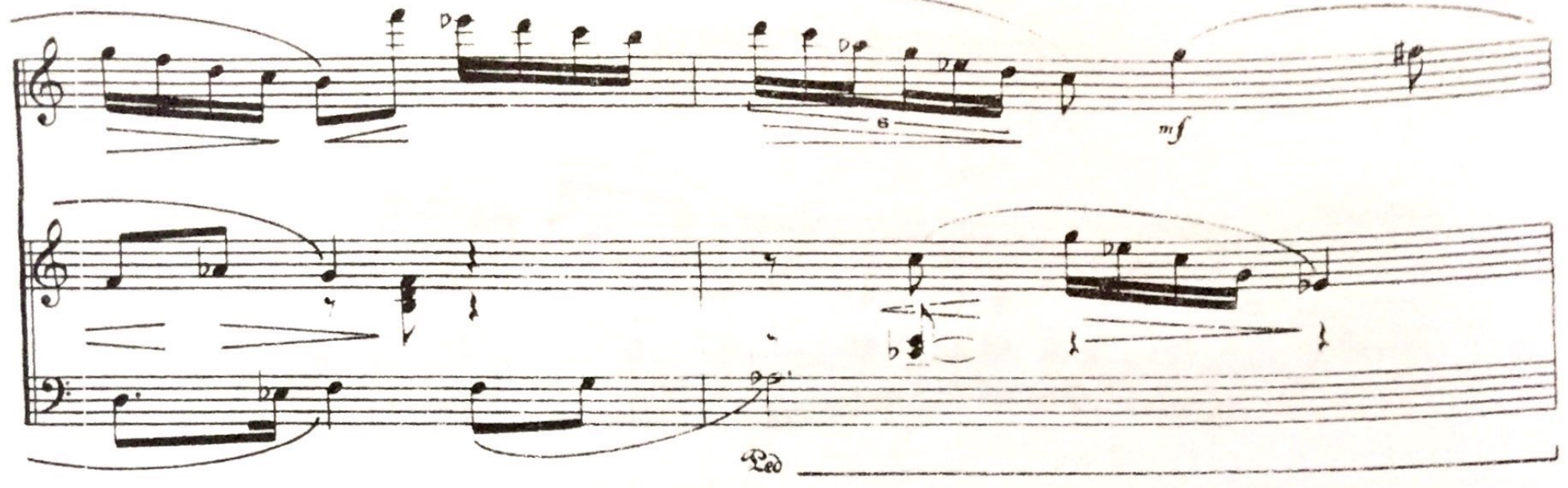

35

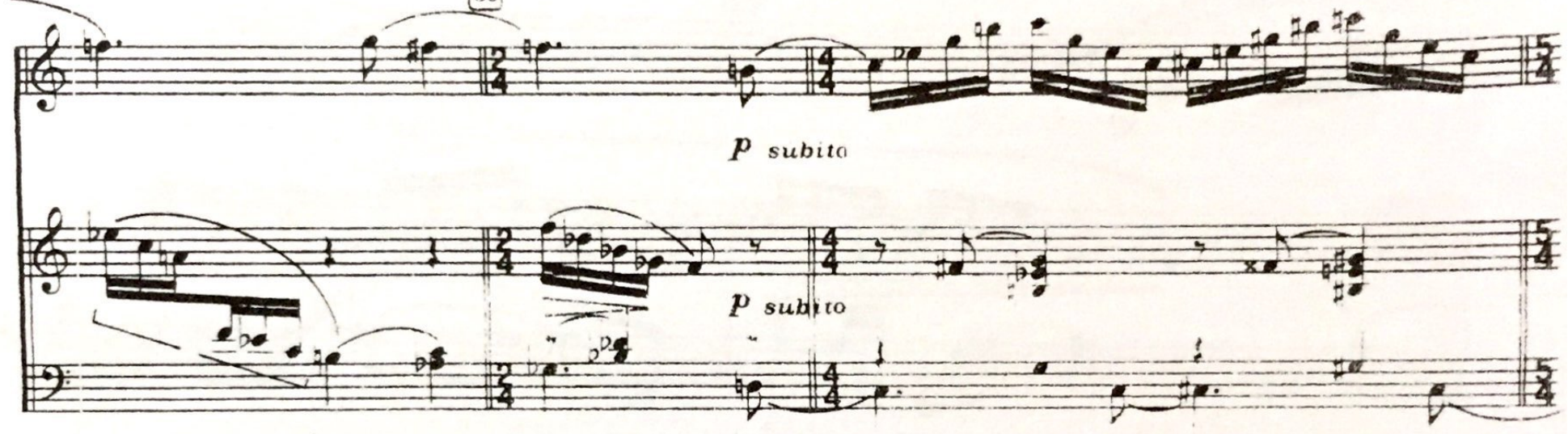
sem peda:
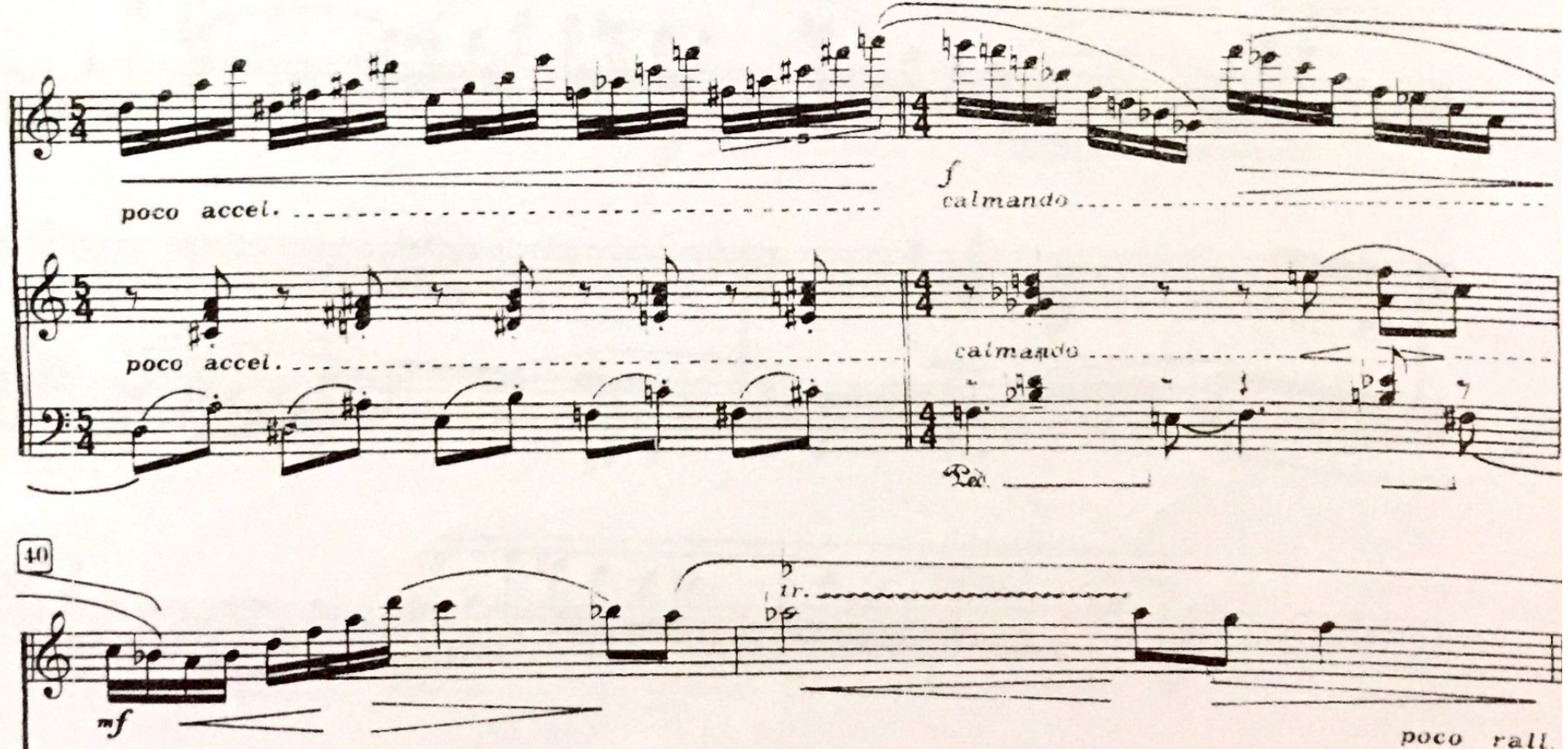

a tempo

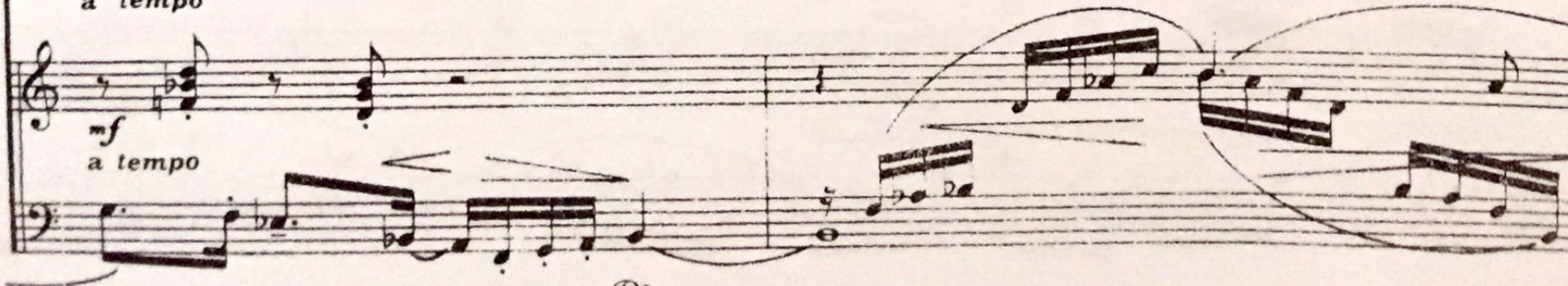


28

a tempo

Q cantando

2:

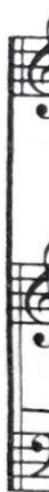

45

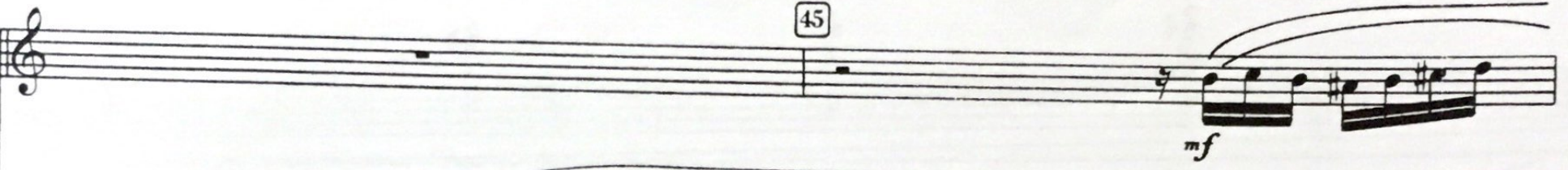

(2)

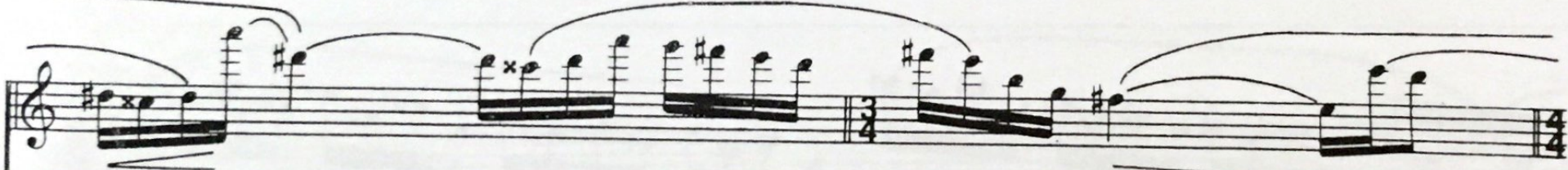

(2)

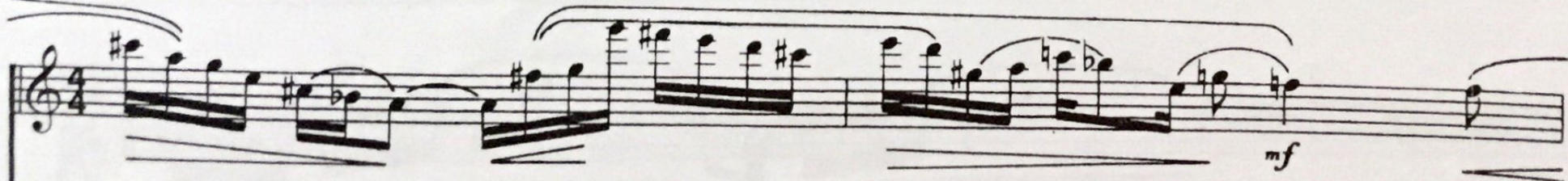

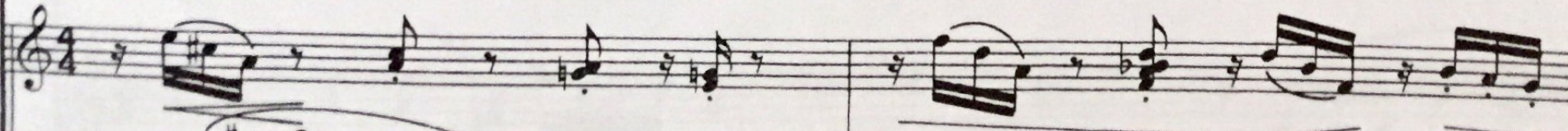

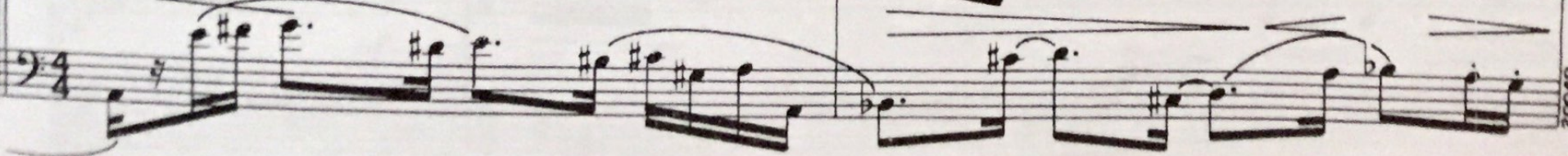


(50)

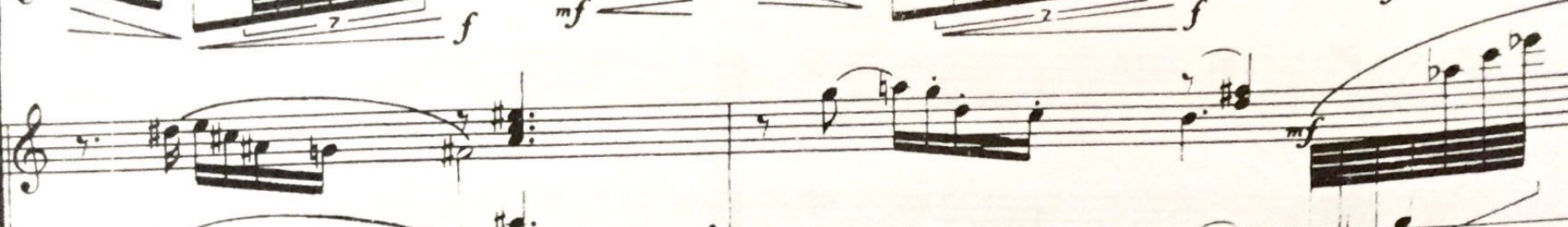

2: $9:$ :

$=\frac{1}{2}+\frac{1}{2}$

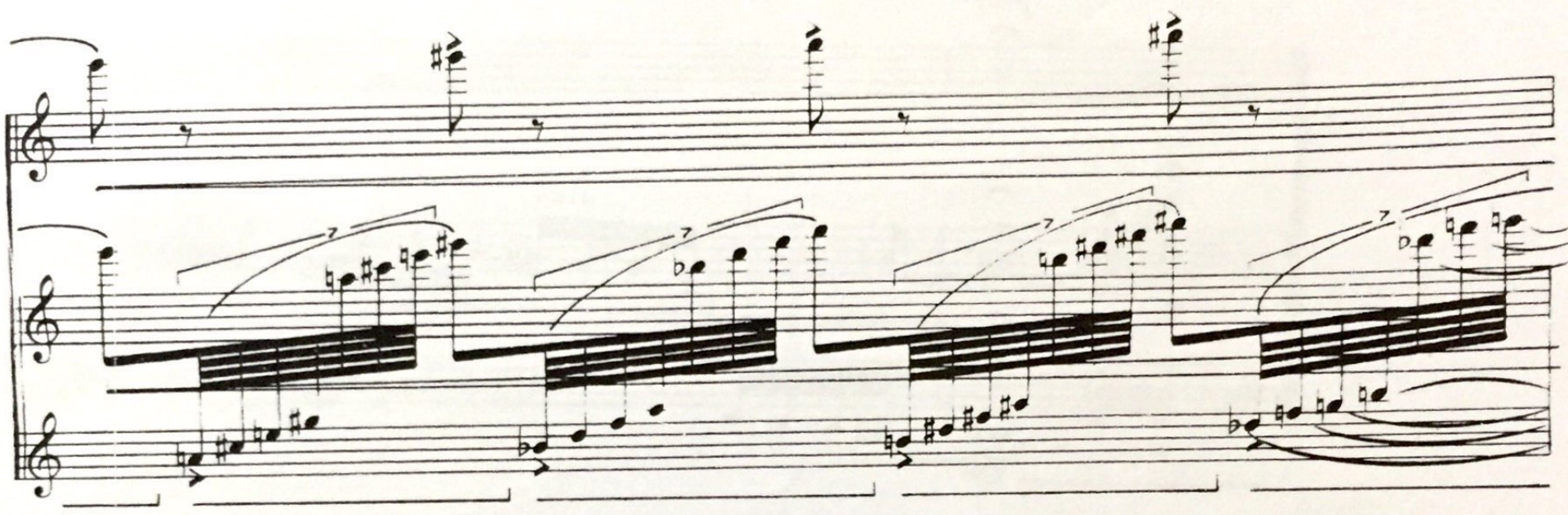

(6)

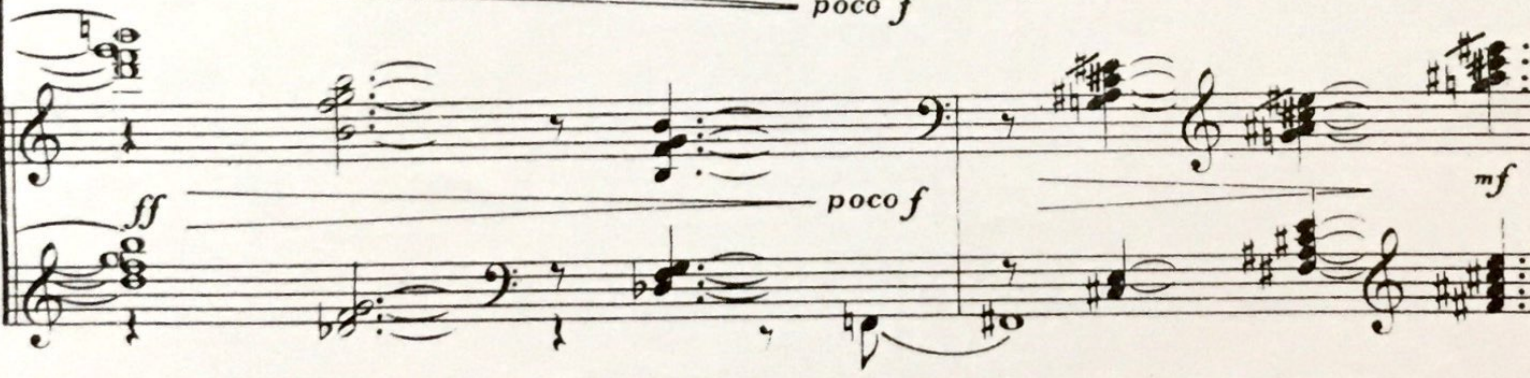

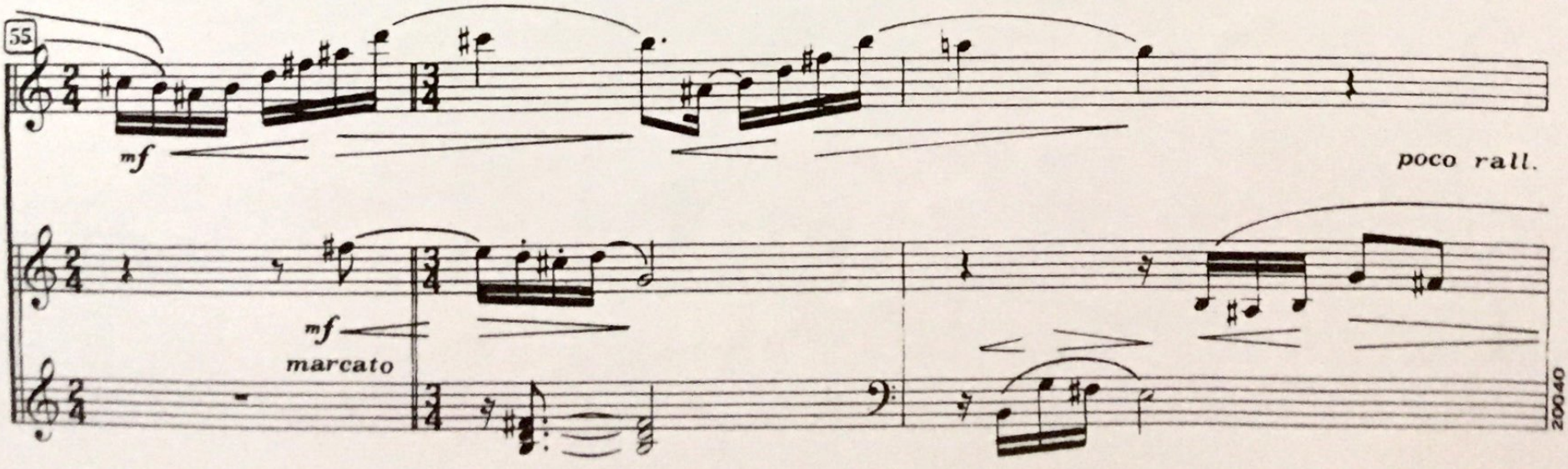


molto espressivo

60

a tempo,ma un poco rit.

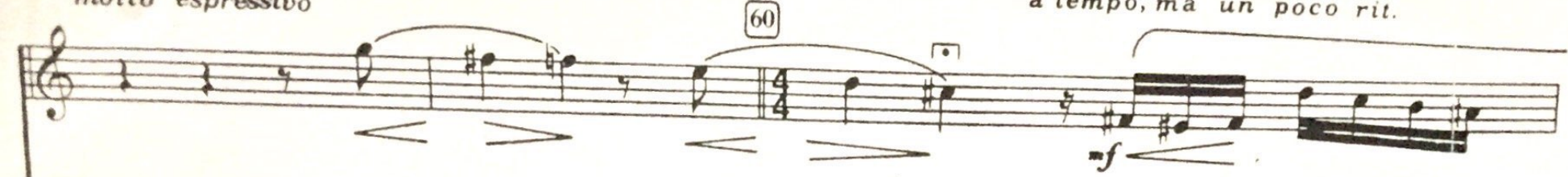

ritenendo

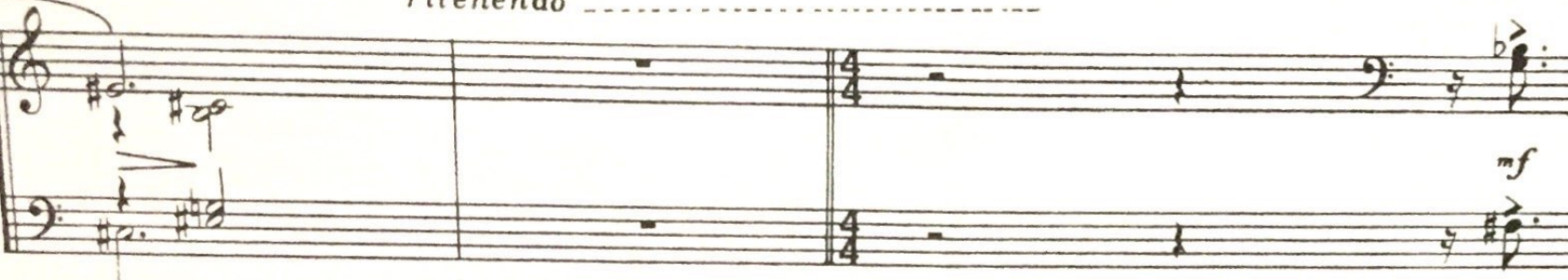

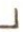

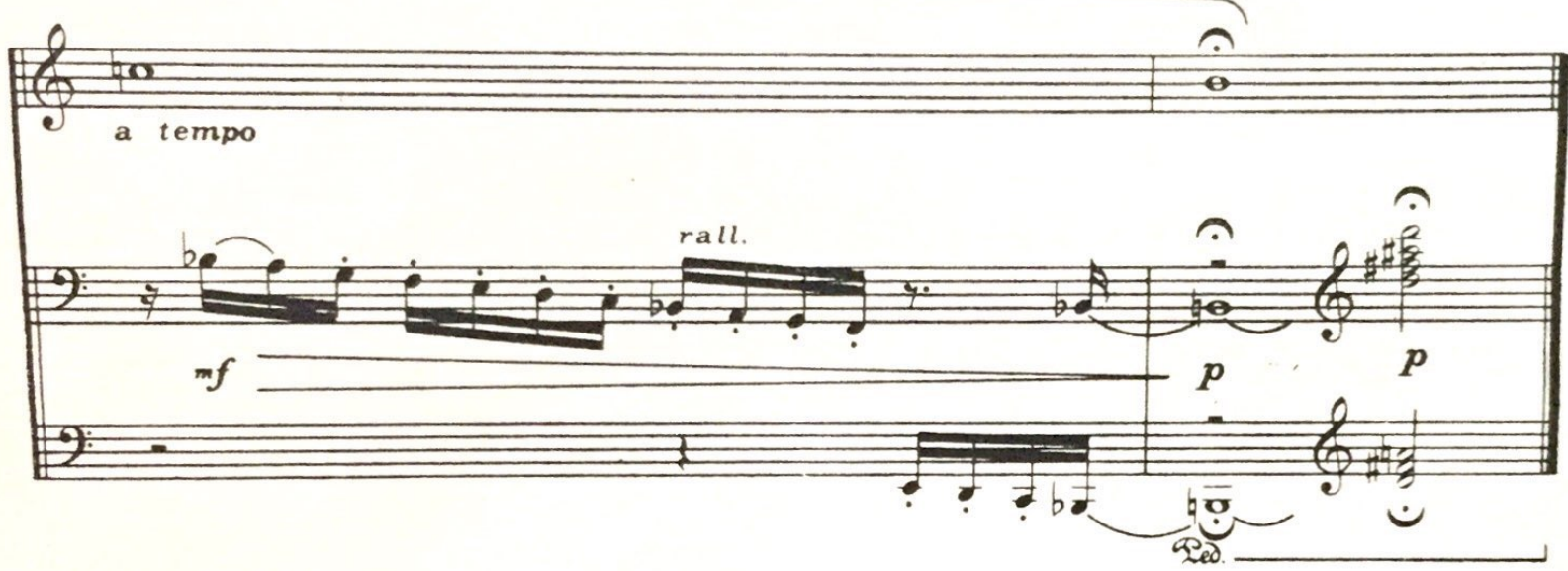

São Paulo, agos to de 1974. 
TRANQUILAMENTE MOVIDO $\left(d_{.}=68\right)$
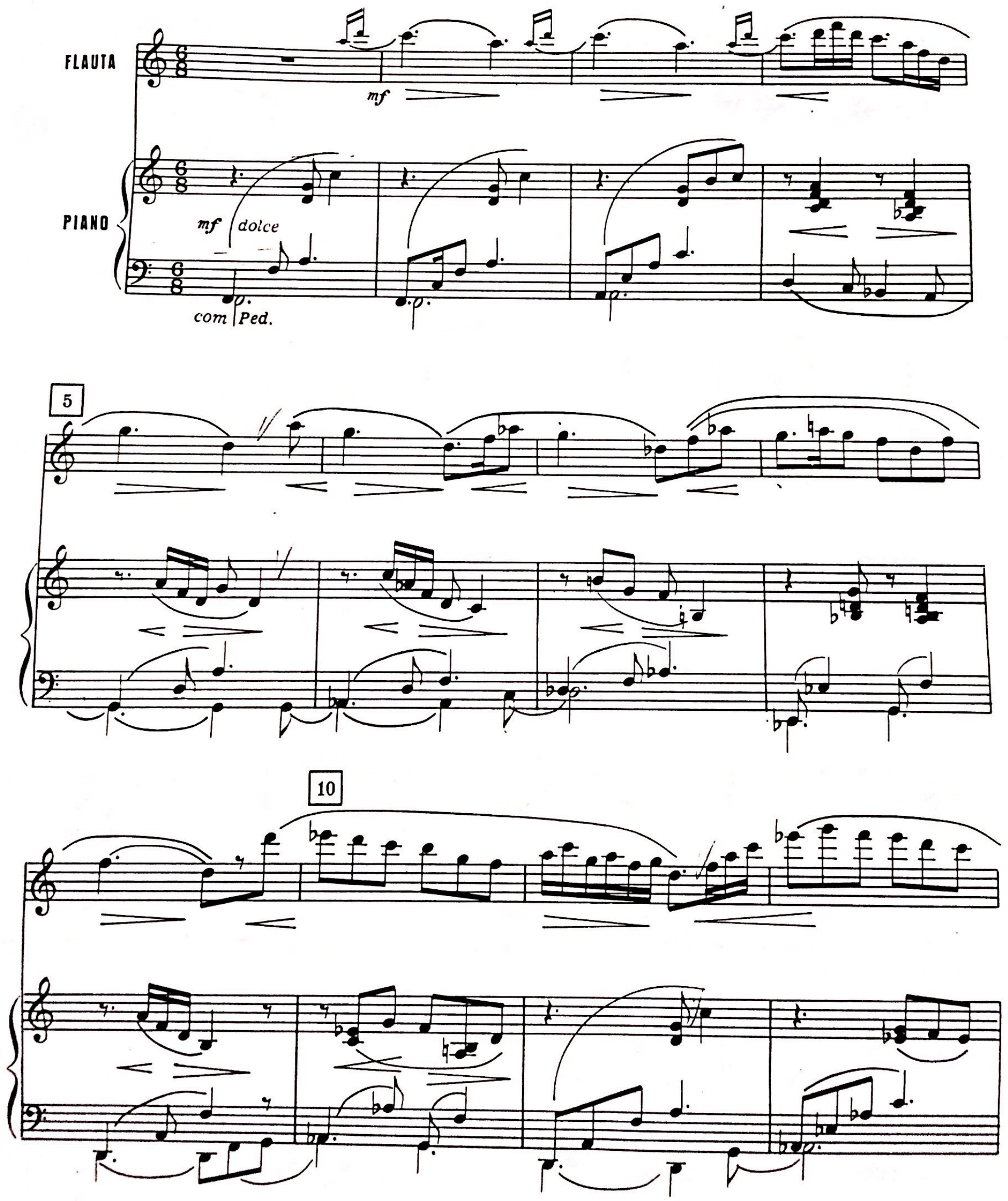

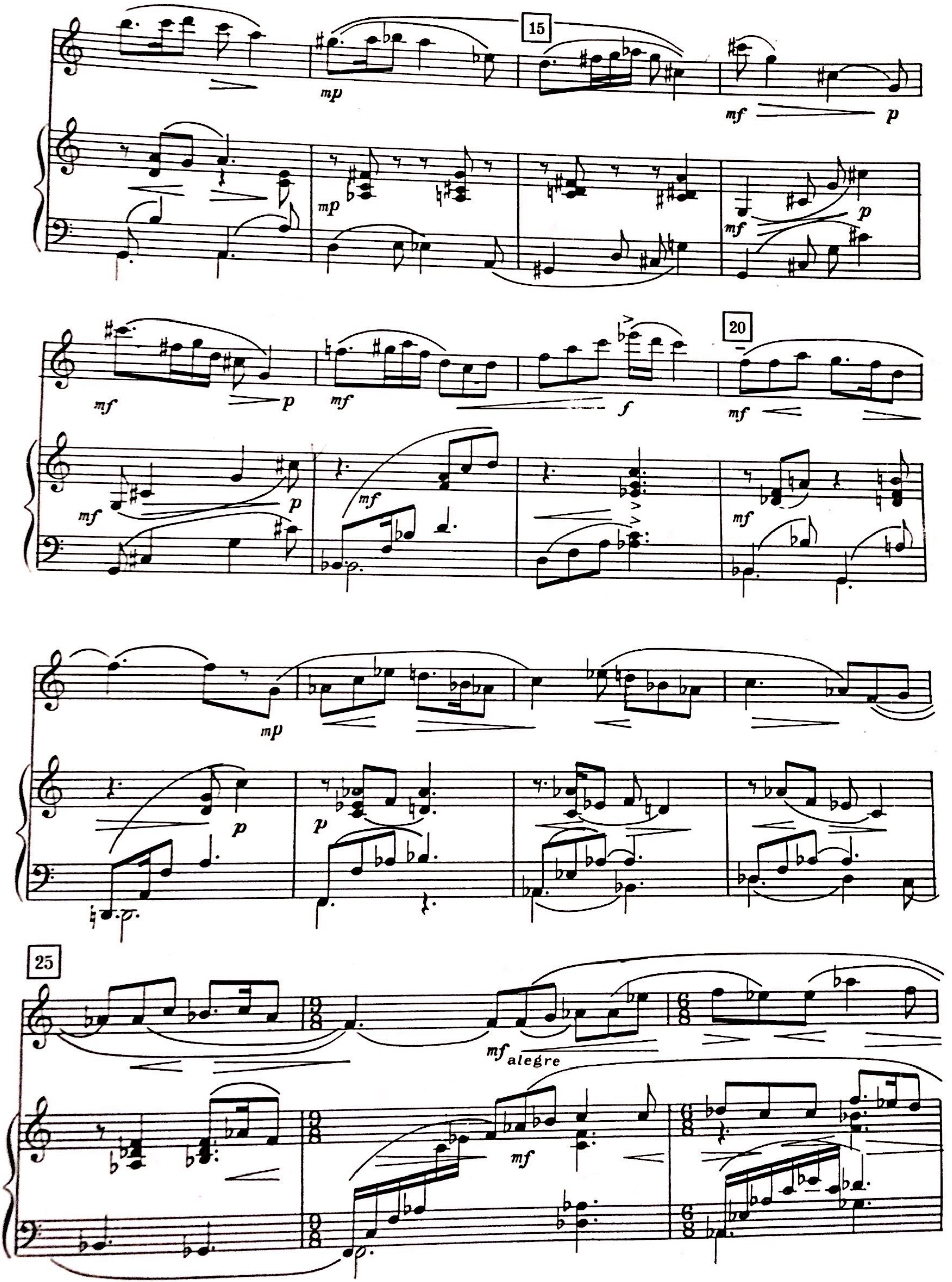
30
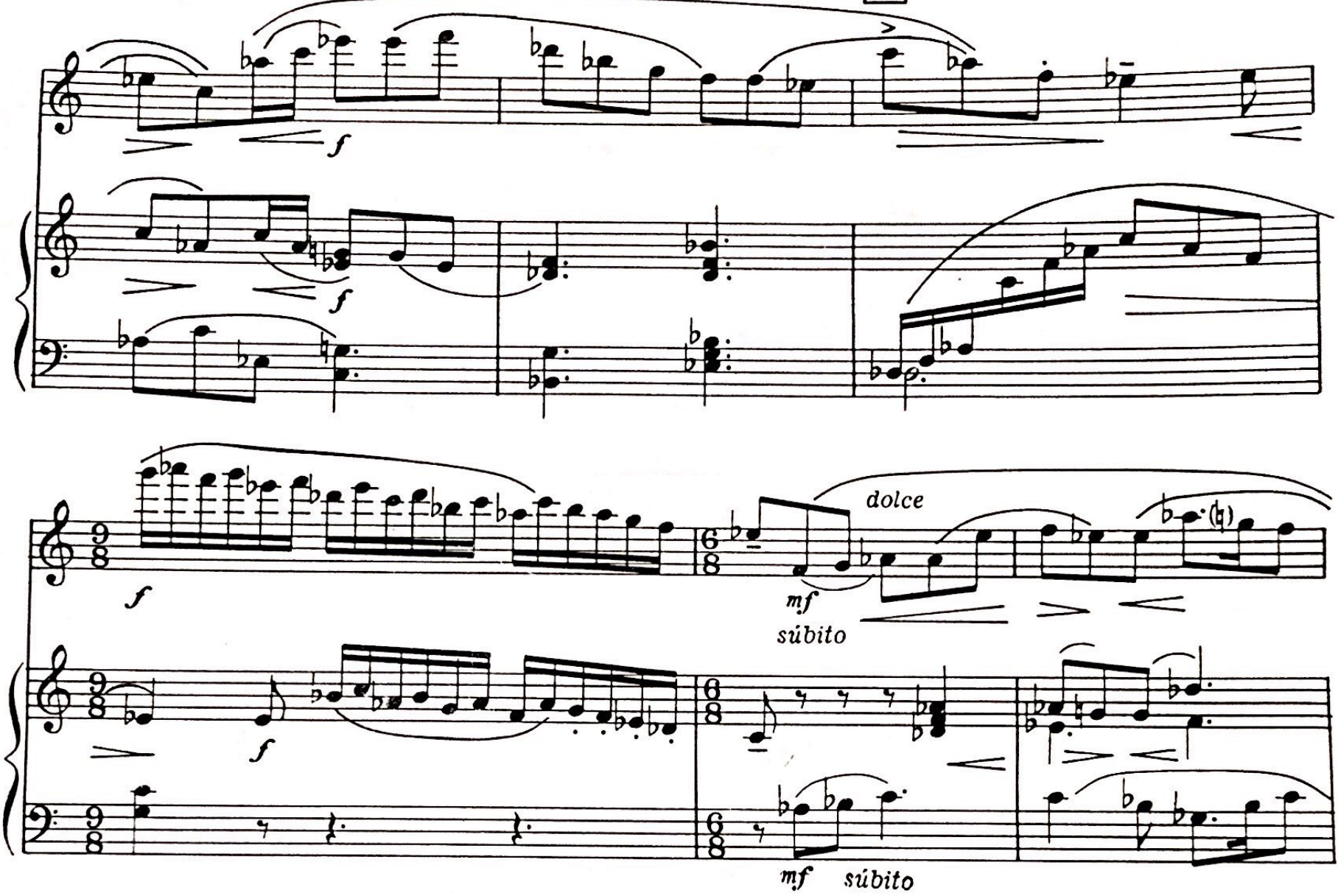

35
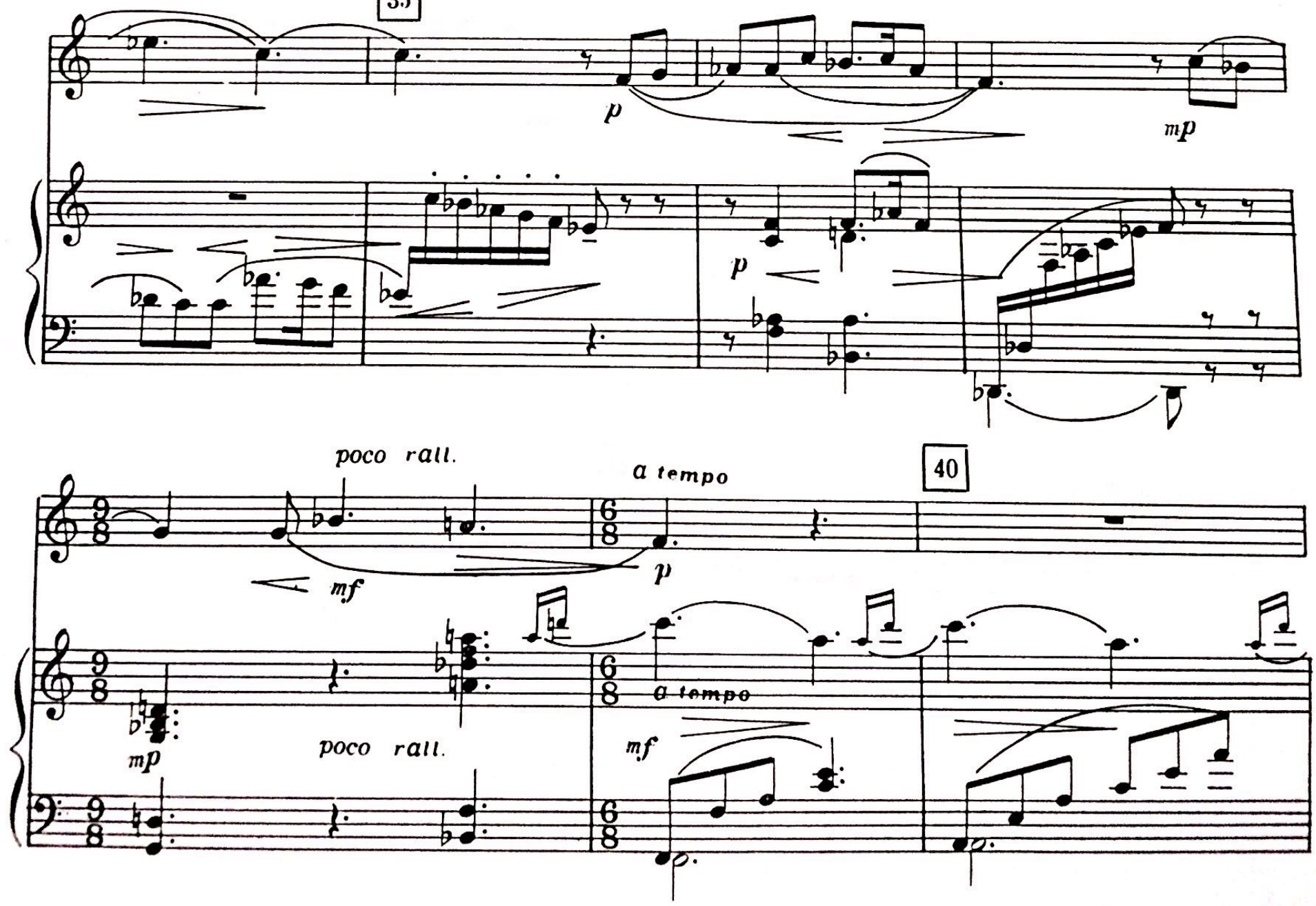

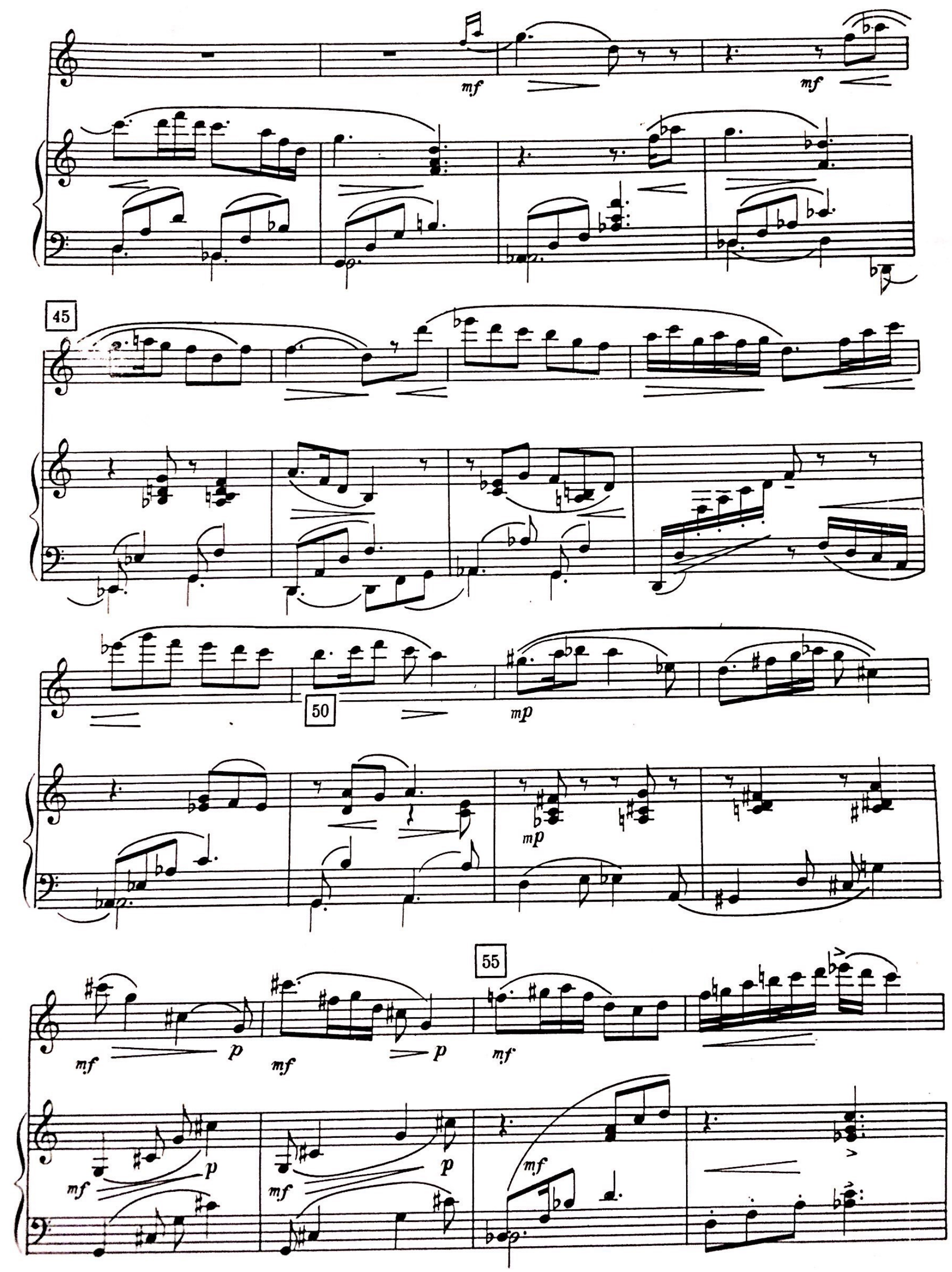

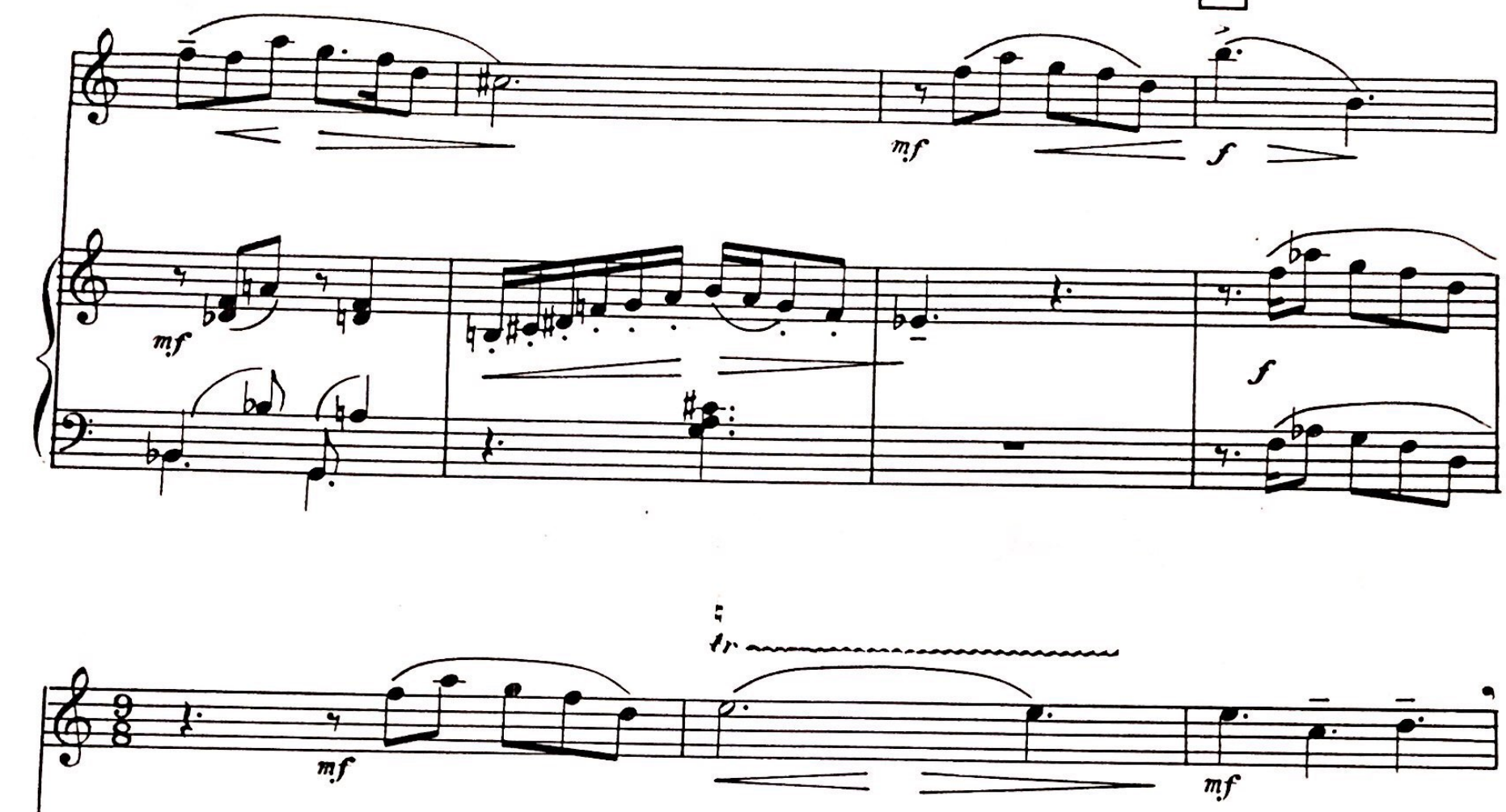

sempre in tempo

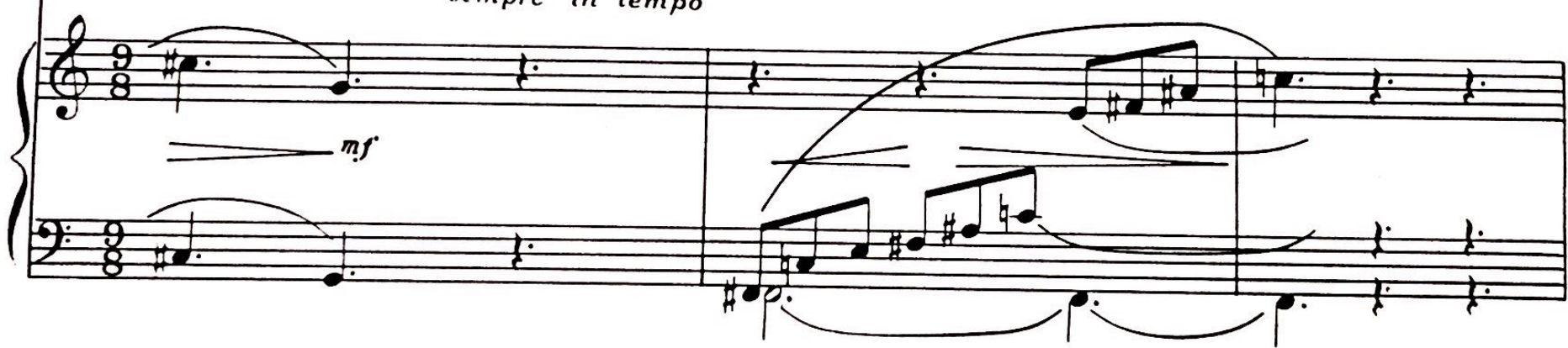

65

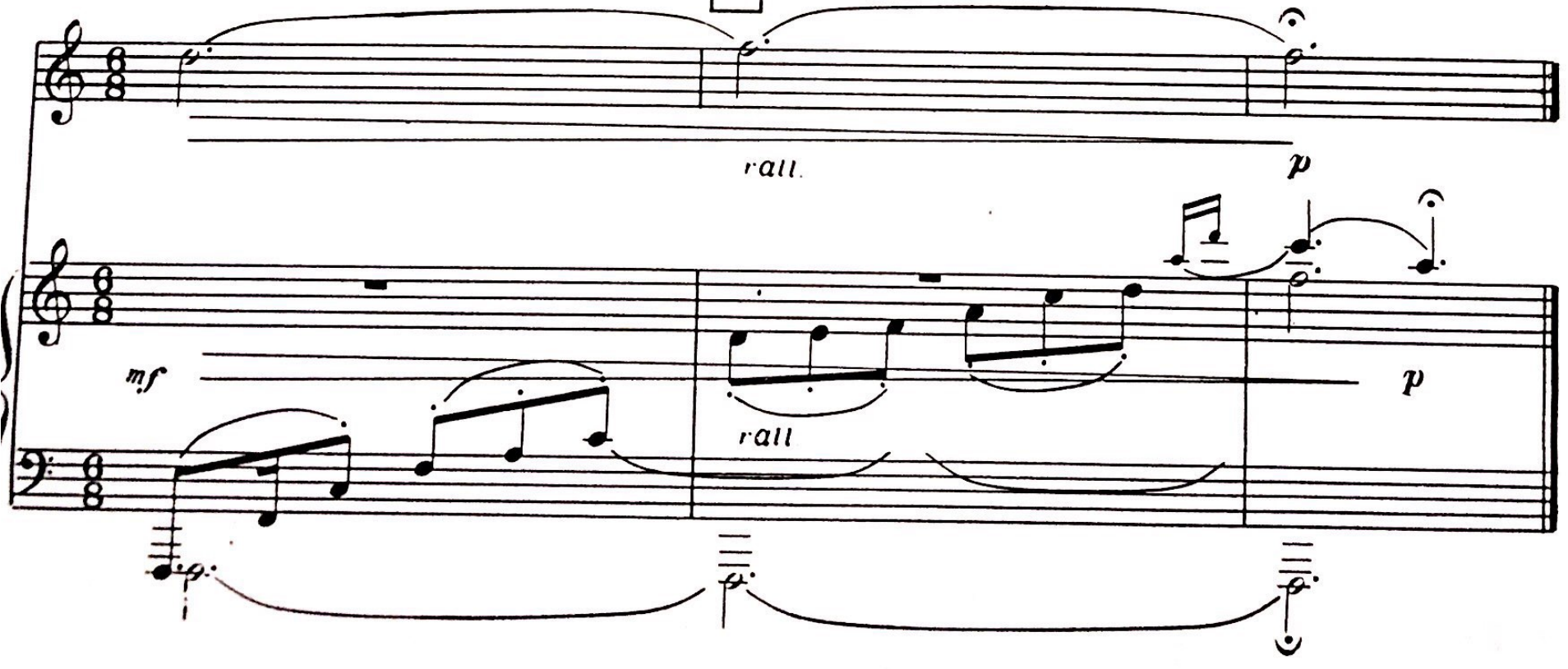

S. Paulo, agosto de 1974 


\section{OS}

\section{1)(1)}

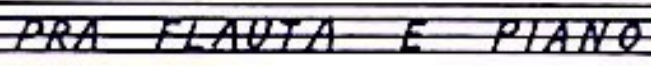



$O L=T O C \quad 30$

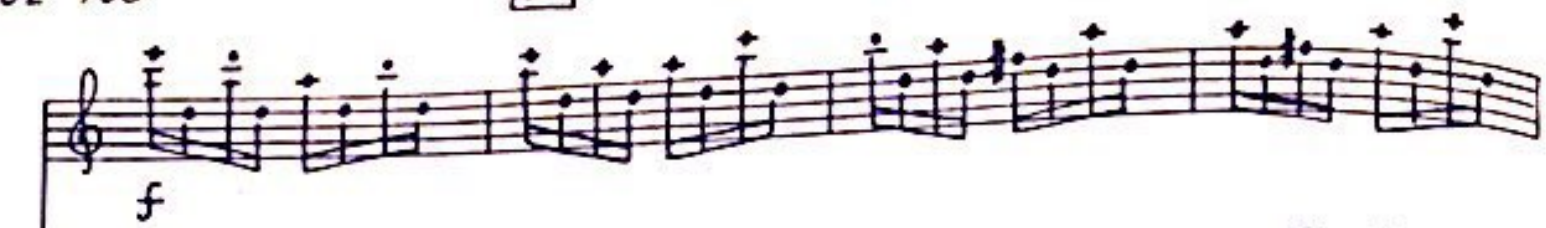

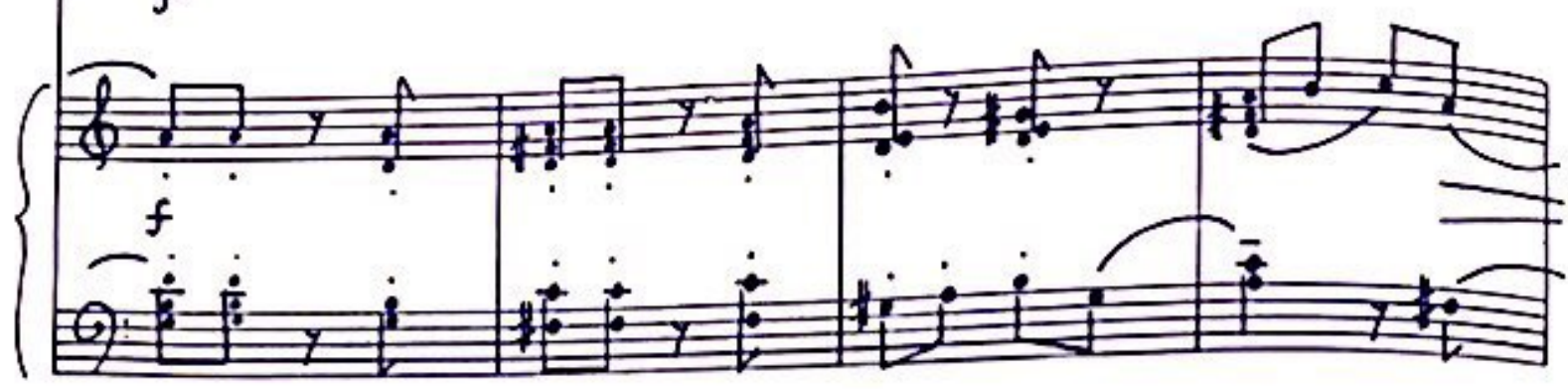

35
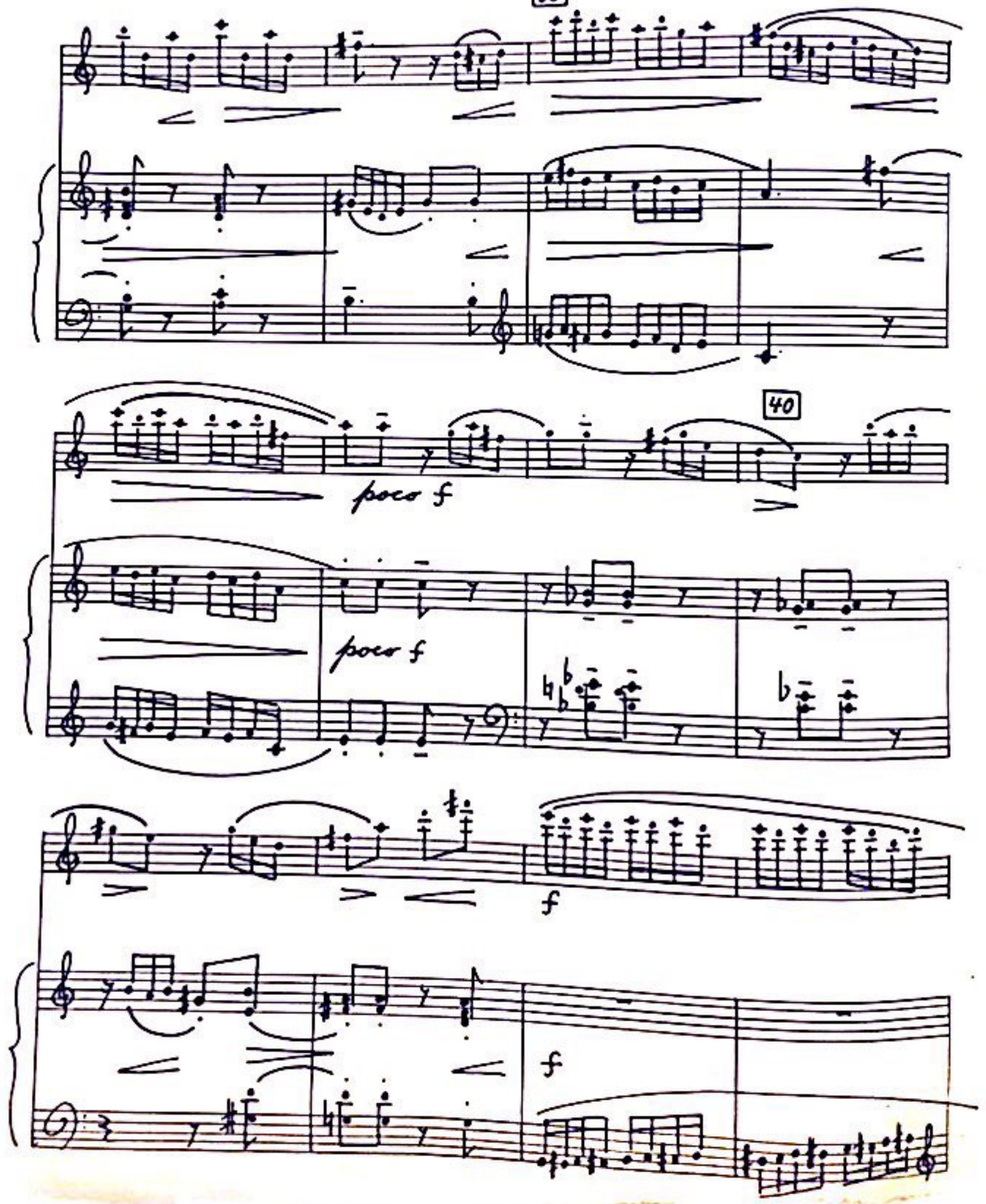

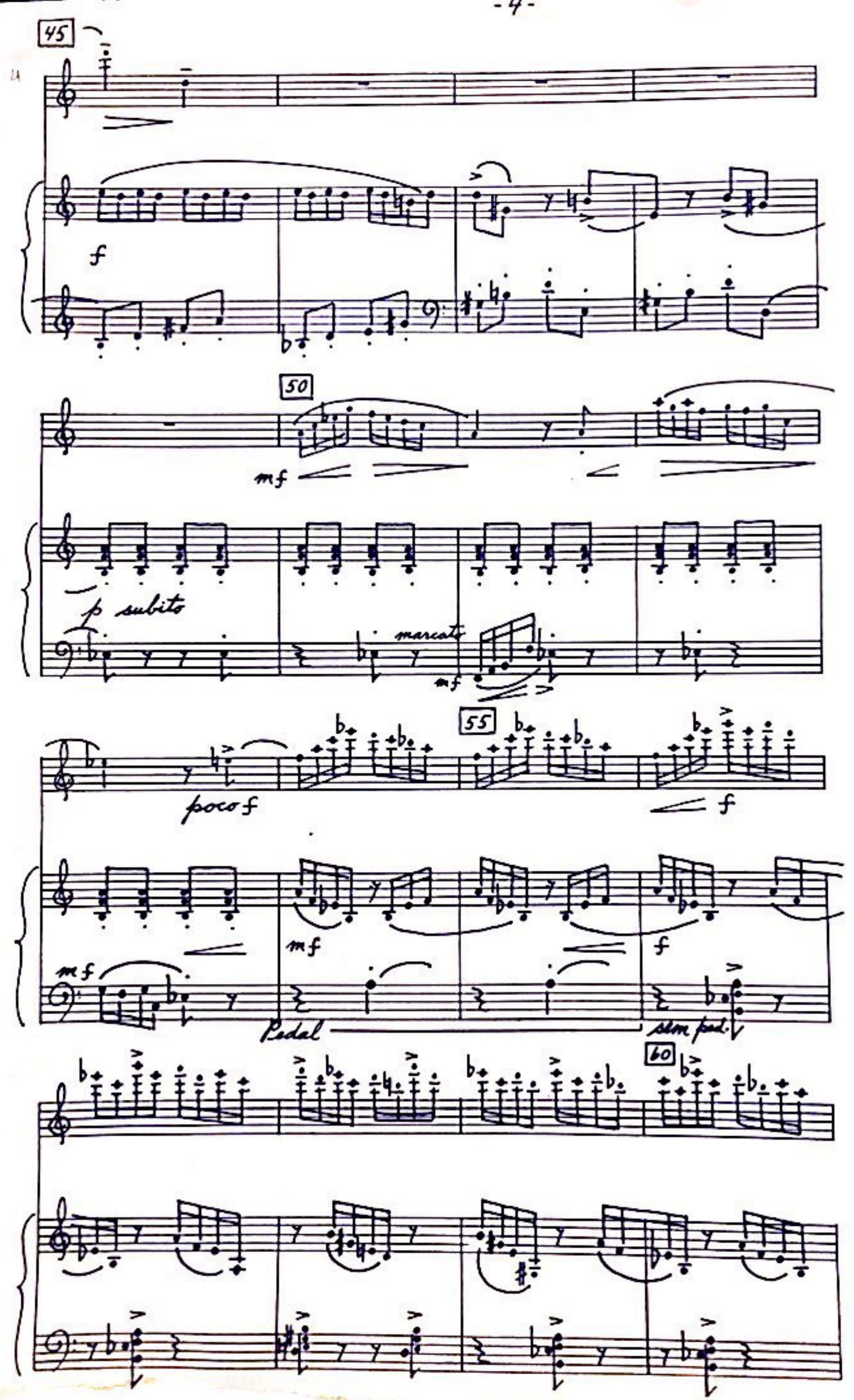


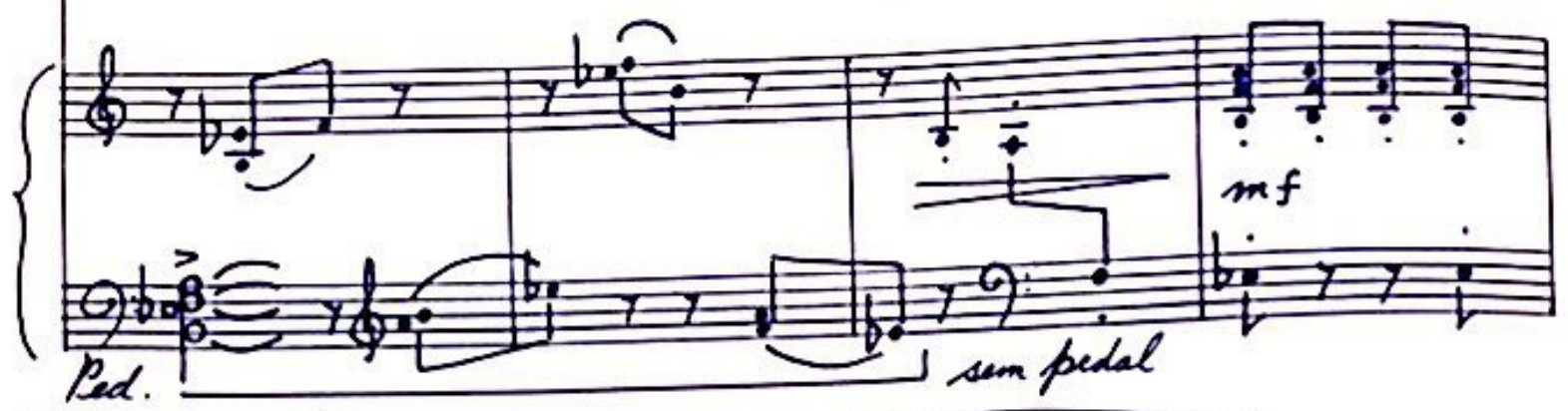

65 Ffoi:

(9)

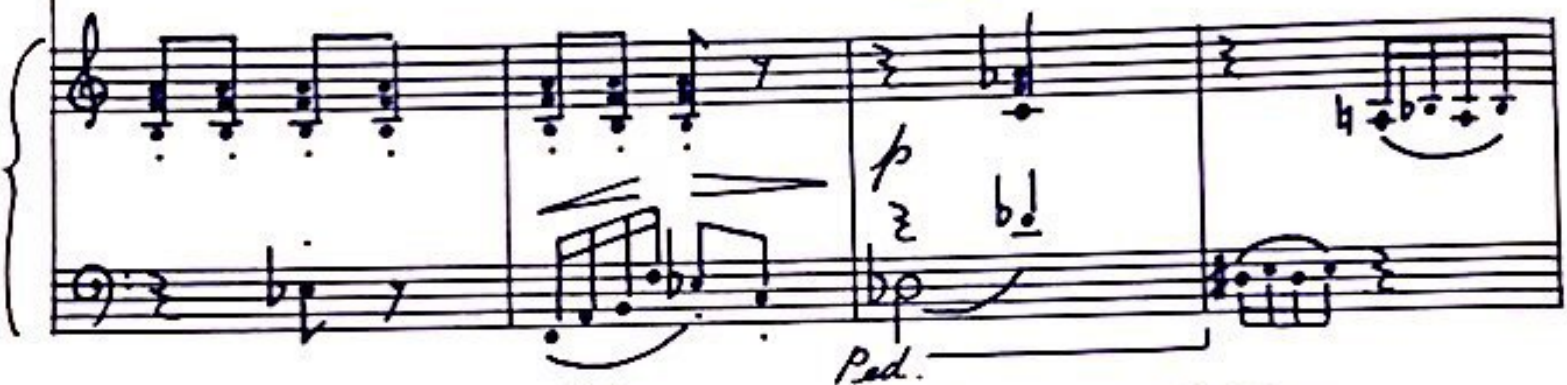

(1)

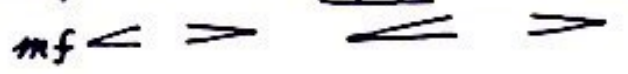

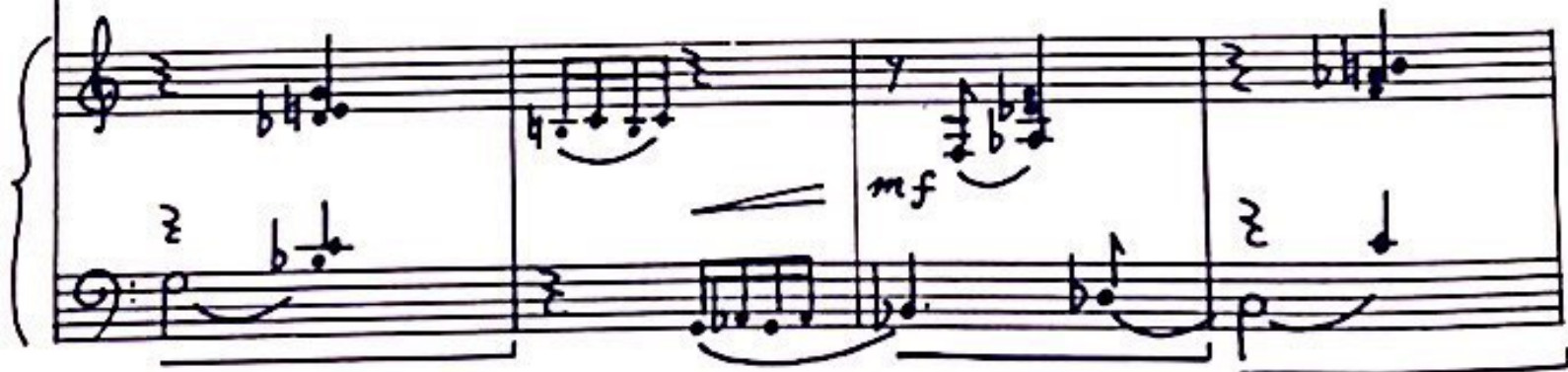

L

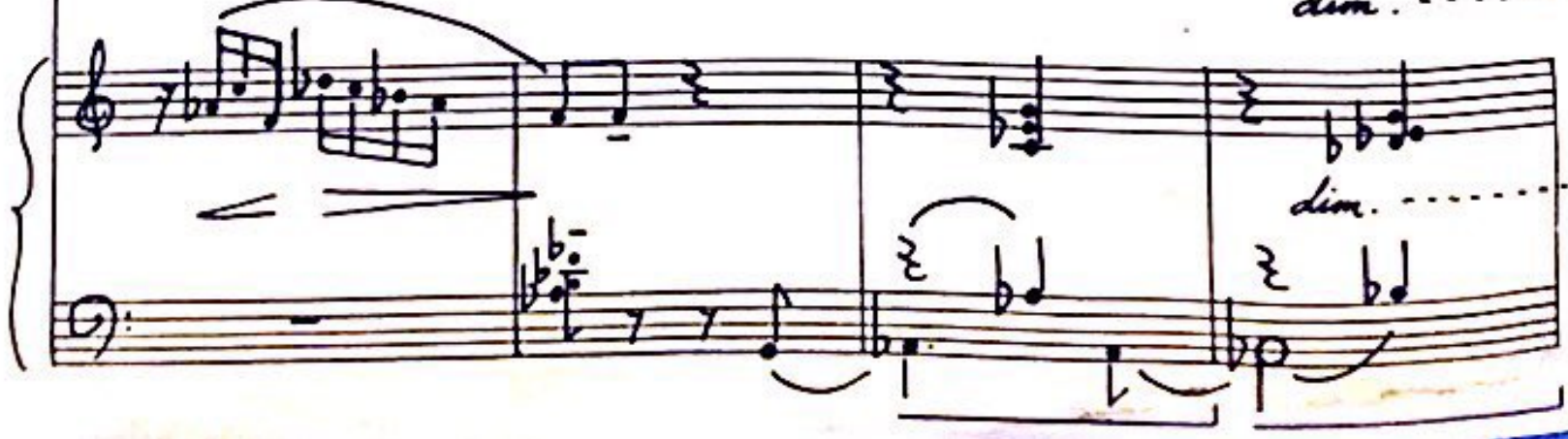


零

podium ate ato

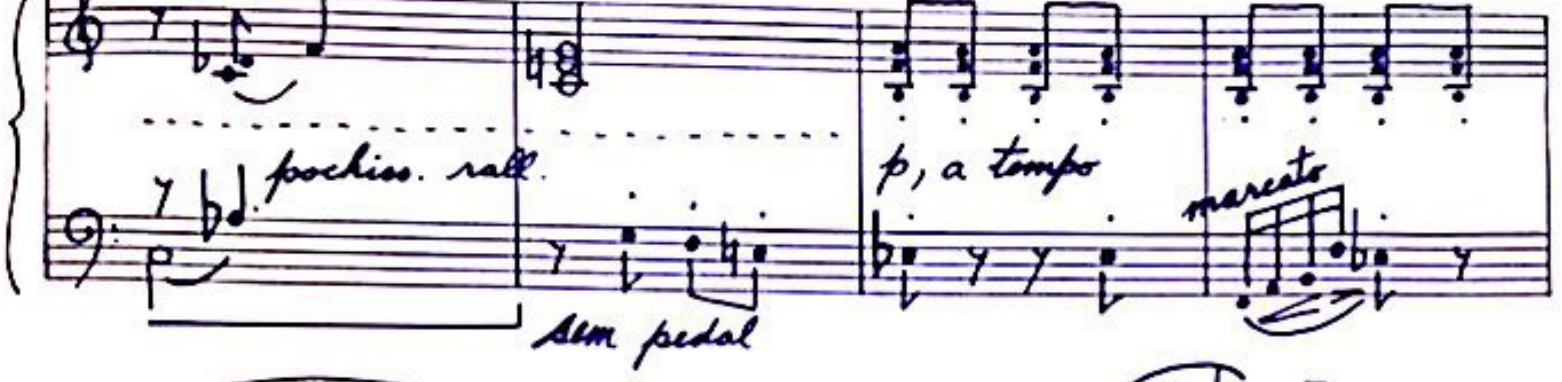

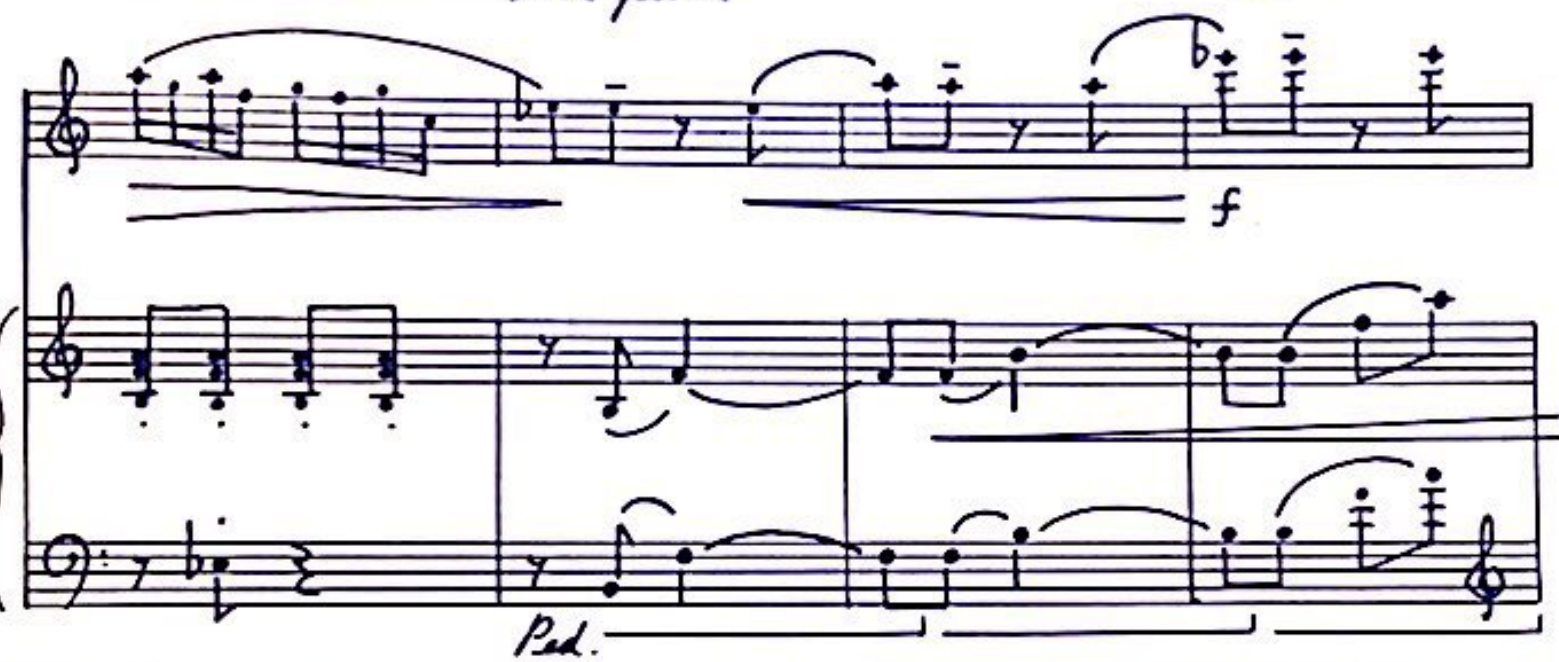

(65) b b b b

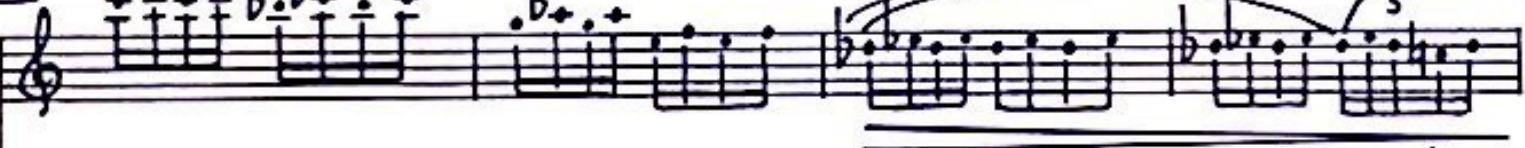
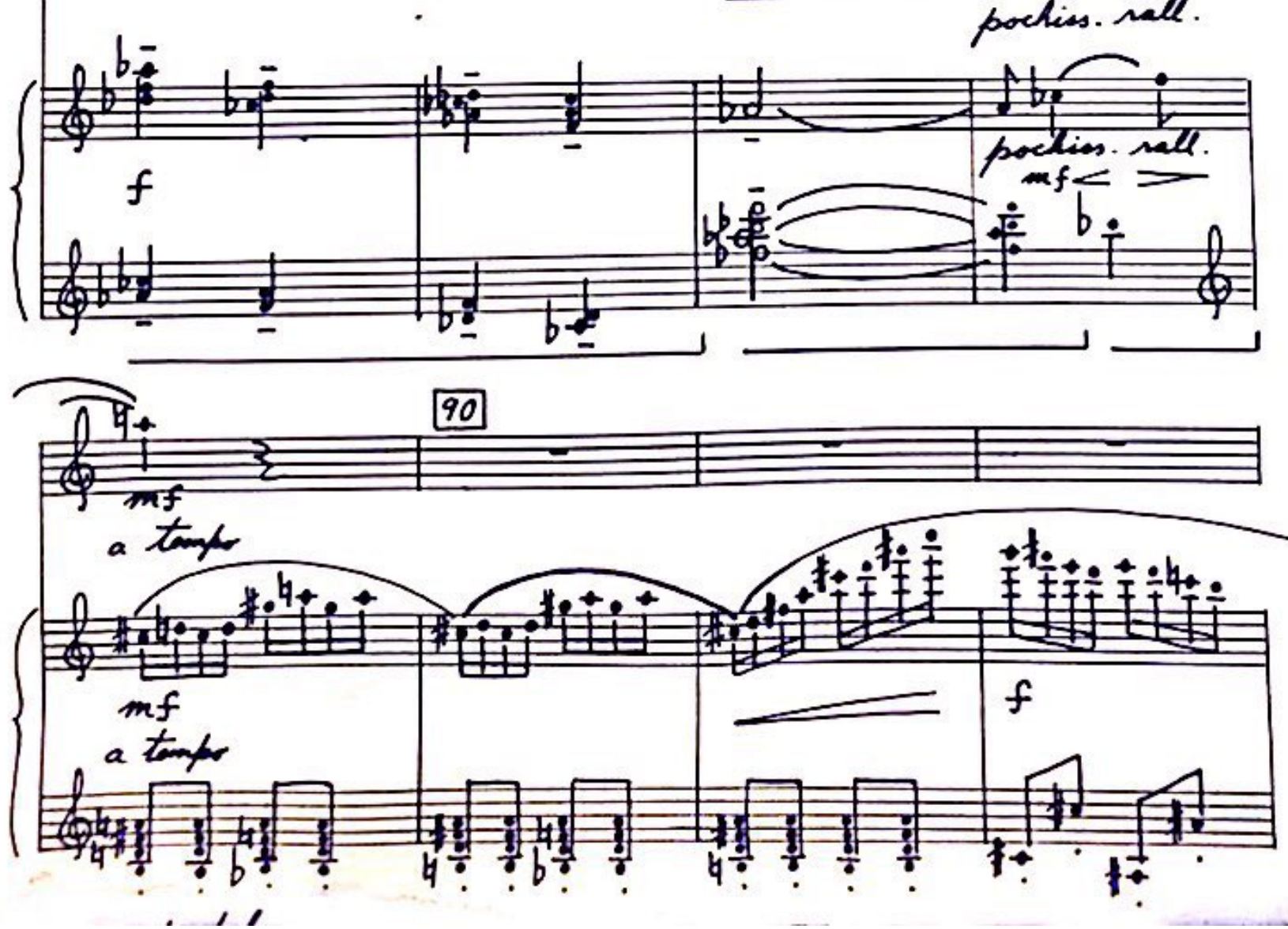
